Prepared in cooperation with the Wisconsin Department of Natural Resources, Village of Cross Plains, Village of Black Earth, Town of Black Earth, Town of Vermont, Village of Mazomanie, and City of Middleton

\title{
Simulation of Climate Change Effects on Streamflow, Groundwater, and Stream Temperature using GSFLOW and SNTEMP in the Black Earth Creek Watershed, Wisconsin
}

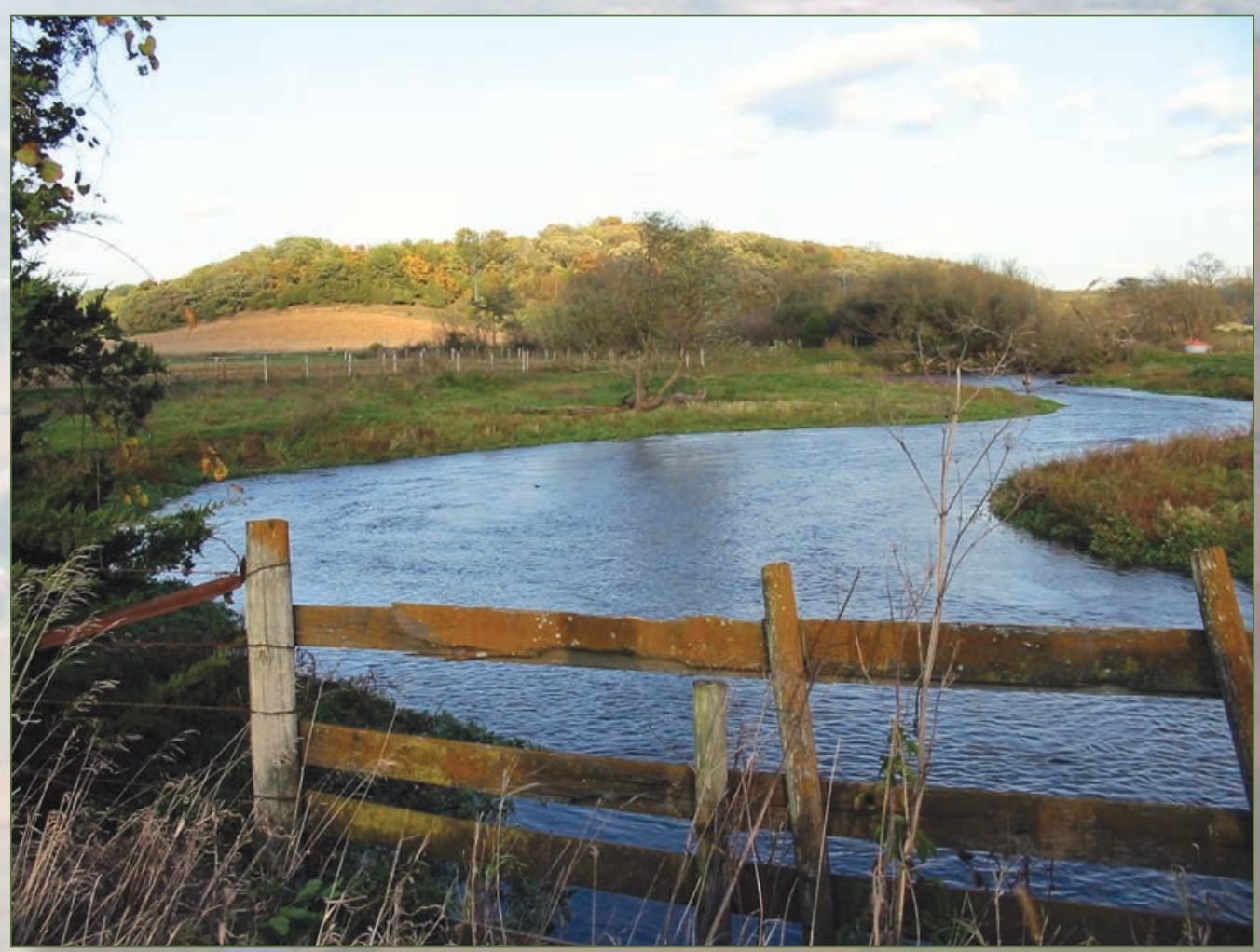

Scientific Investigations Report 2016-5091 
Cover. Photographs by Richard A. Anderson. 


\section{Simulation of Climate Change Effects on Streamflow, Groundwater, and Stream Temperature using GSFLOW and SNTEMP in the Black Earth Creek Watershed, Wisconsin}

By Randall J. Hunt, Stephen M. Westenbroek, John F. Walker, William R. Selbig, R. Steven Regan, Andrew T. Leaf, and David A. Saad

Prepared in cooperation with the Wisconsin Department of Natural Resources, Village of Cross Plains, Village of Black Earth, Town of Black Earth, Town of Vermont, Village of Mazomanie, and City of Middleton

Scientific Investigations Report 2016-5091 


\title{
U.S. Department of the Interior SALLY JEWELL, Secretary
}

\section{U.S. Geological Survey Suzette M. Kimball, Director}

\author{
U.S. Geological Survey, Reston, Virginia: 2016
}

For more information on the USGS - the Federal source for science about the Earth, its natural and living resources, natural hazards, and the environment—visit http://www.usgs.gov or call 1-888-ASK-USGS.

For an overview of USGS information products, including maps, imagery, and publications, visit http://store.usgs.gov.

Any use of trade, firm, or product names is for descriptive purposes only and does not imply endorsement by the U.S. Government.

Although this information product, for the most part, is in the public domain, it also may contain copyrighted materials as noted in the text. Permission to reproduce copyrighted items must be secured from the copyright owner.

Suggested citation:

Hunt, R.J., Westenbroek, S.M., Walker, J.F., Selbig, W.R., Regan, R.S., Leaf, A.T., and Saad, D.A., 2016, Simulation of climate change effects on streamflow, groundwater, and stream temperature using GSFLOW and SNTEMP in the Black Earth Creek Watershed, Wisconsin: U.S. Geological Survey Scientific Investigations Report 2016-5091, 117 p., http://dx.doi.org/10.3133/sir20165091.

ISSN 2328-0328 (online) 


\section{Contents}

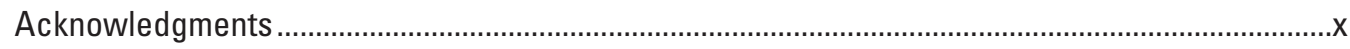

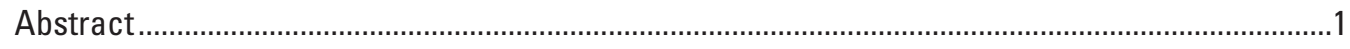

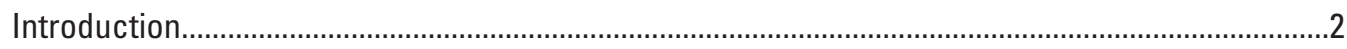

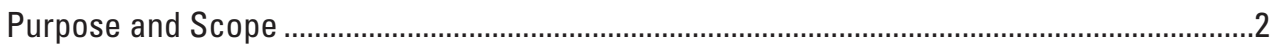

Site Description and Hydrologic Setting..............................................................................

GSFLOW Groundwater/Surface-Water Modeling Approach .......................................................

Brief Description of Groundwater Model Construction ..........................................................

Brief Description of Surface-Water Model Construction ........................................................

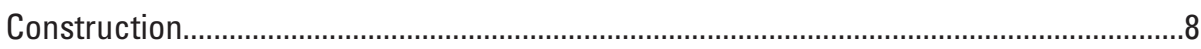

Hydrologic Response Units .............................................................................

Surface-Water Routing ..........................................................................................

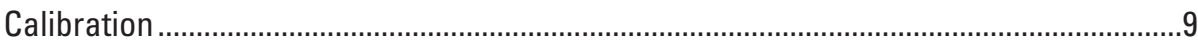

Considerations for Designing a Coupled Groundwater/Surface-Water Model.......................13

Considerations for Calibrating a Coupled Groundwater/Surface-Water Model.....................13

SNTEMP Temperature Model Description, Construction, and Calibration .......................................14

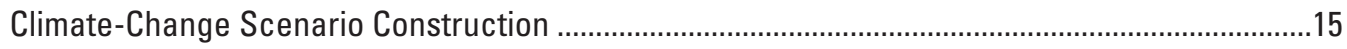

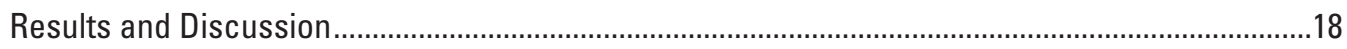

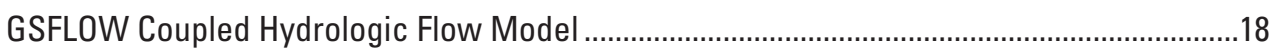

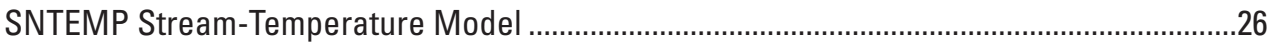

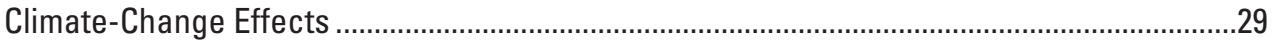

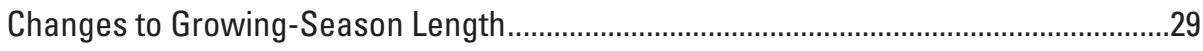

Changes to Basin-Scale Hydrologic Flows and Storage ..............................................29

Changes to Streamflow ..........................................................................................

Changes to Spring Discharge East of the Village of Cross Plains .....................................36

Changes to Groundwater Levels ....................................................................................36

Changes to Stream Temperature ................................................................................36

Example of Mitigation of Climate Effects with Land Use Change ...........................................4

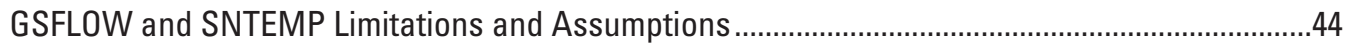

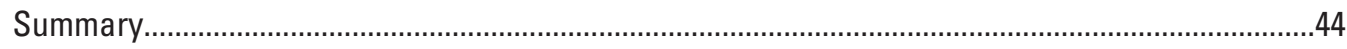

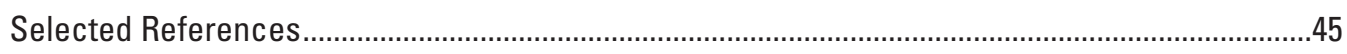

Appendix 1. Black Earth Creek Groundwater Model Construction and Calibration.........................52

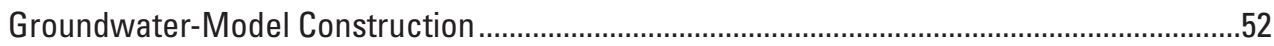

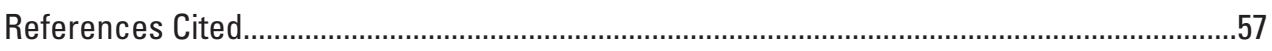

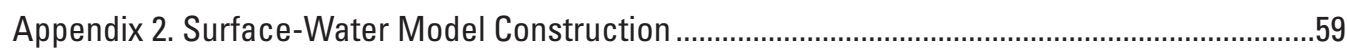

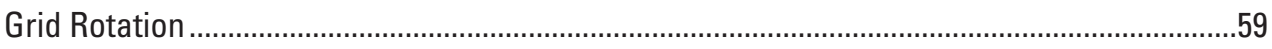

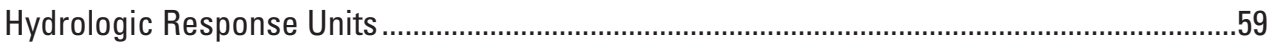

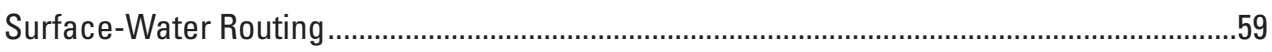

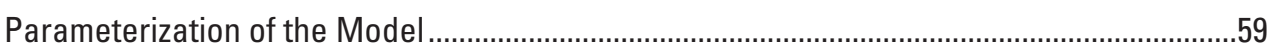

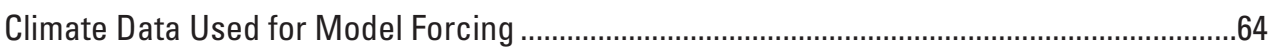

Variation of Growing Season with Changing Temperatures .................................................66

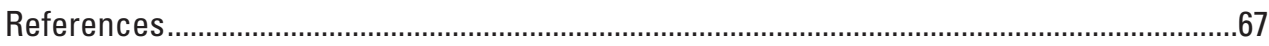

Appendix 3. Model Calibration..............................................................................................

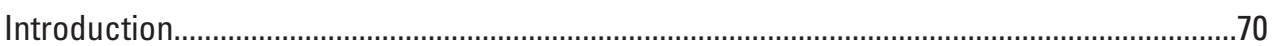


Time-Series Processing Approach .....................................................................................

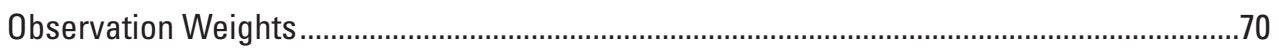

Calibration Approach—Uncoupled Models..........................................................................

Step 1-Solar Radiation and Potential Evapotranspiration ................................................71

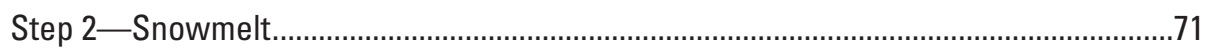

Step 3-Runoff, Infiltration, and Base Flow Groundwater Flow......................................72

MODFLOW-Only Uncoupled Model.................................................................................73

Calibration Approach—Fully Coupled Surface-Water/Groundwater Model ...........................75

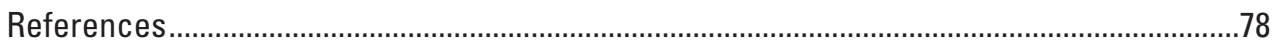

Appendix 4. Temperature Model Construction and Calibration .........................................................79

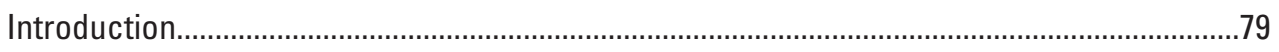

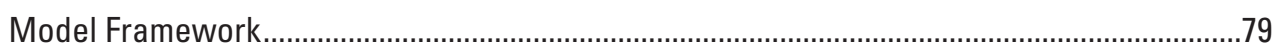

Model Input and Calibration/Verification Data …….......................................................79

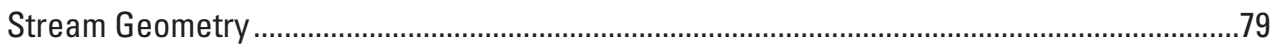

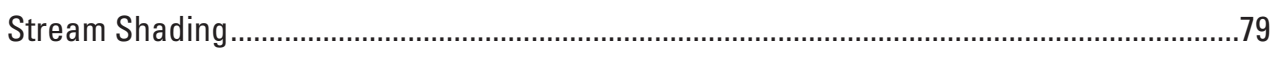

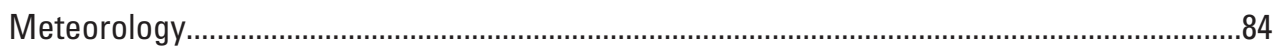

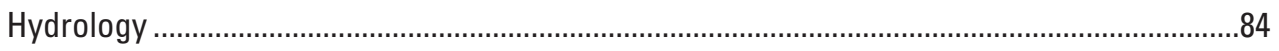

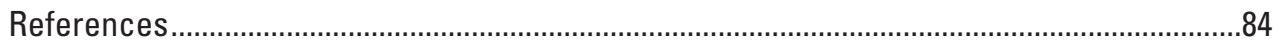

Appendix 5. Field Data Collection (2004-2005) …………….....................................................

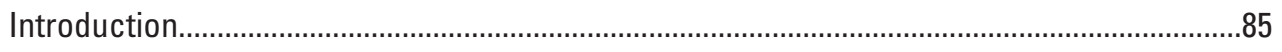

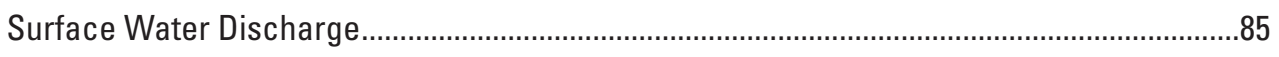

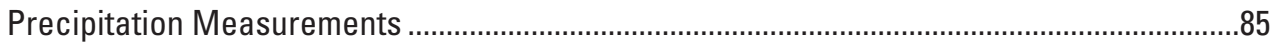

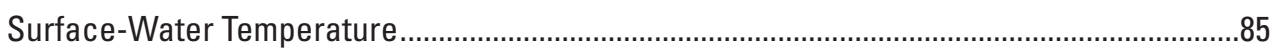

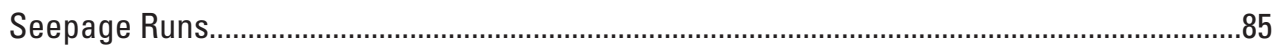

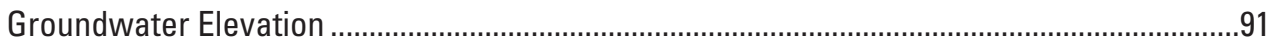

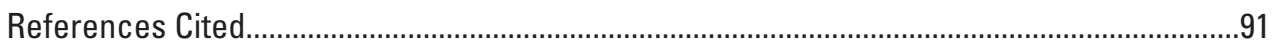

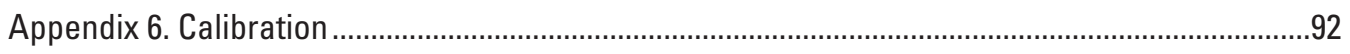

Precipitation-Runoff Modeling System (PRMS)-Only Calibration Results ............................92

Uncoupled MODFLOW-only Calibration Results ................................................................92

Fully Coupled GSFLOW Calibration Results....................................................................92

References Cited..............................................................................................................

\section{Figures}

1. Map showing the Black Earth Creek groundwatershed and surface watershed,

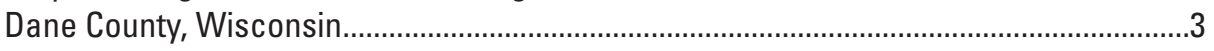

2. Map showing the Black Earth Creek model grid, boundary conditions, and calibration targets

3. Map showing Pleistocene geology of the Black Earth Creek watershed model domain

4. Map showing groundwatershed and hydrologic response units generated for the Black Earth Creek surface-water model ......................................................................10

5. Map showing overland flow routing map generated for the Black Earth Creek

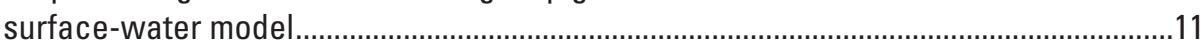

6. Map showing locations of precipitation and air temperature monitoring stations.........12 
7. Graphs showing climate forcings from the Wisconsin Initiative on Climate Change Impacts (WICCI) downscaled data for six General Circulation Models (GCMs) ............17

8. Graph showing annual precipitation measured around the Black Earth Creek watershed during the 2000-7 calibration period compared to the average precipitation used for the simulation.

9. Graphs showing annual and monthly simulated precipitation and actual evapotranspiration over the Black Earth Creek watershed, 2000-7.

10. Graphs showing observed and simulated heads for the shallow aquifer and deep confined aquifer east of the Village of Cross Plains.

11. Graph showing simulated monthly precipitation, infiltration, and recharge over the Black Earth Creek watershed during the calibration period

12. Graphs showing simulated daily flows and log daily flows for the Black Earth Creek watershed (2000-7).

13. Graph showing watershed-wide simulated changes in water stored in the unsaturated zone and rate of groundwater recharge reported as inches over the watershed area.

14. Graphs showing simulated and observed daily mean stream temperatures at select locations in Black Earth Creek, May-September 2005.

15. Graph showing comparison between simulated and observed daily mean stream temperatures at select locations in Black Earth Creek, May-September 2005...

16. Graph showing difference between observed and simulated daily mean stream temperatures at select locations in Black Earth Creek, May-September 2005.

17. Graph showing change in growing-season length related to potential climate change, defined as the difference between the date of the first killing frost in the fall and the date of the last killing frost in the spring.

18. Graphs showing climate-change scenario results for total volumes of rainfall, snowfall, and the resulting snowpack, normalized to the watershed area

19. Graphs showing climate-change scenario results for total volumes of potential, and actual evapotranspiration, and the resulting watershed-wide average soil moisture, normalized to the watershed area

20. Graphs showing climate-change scenario results for monthly watershedwide potential evapotranspiration, actual evapotranspiration, and resulting average soil moisture.

21. Graphs showing climate-change scenario groundwater recharge results for watershedwide, annual average time series statistical summary, and monthly average recharge to the groundwater system.

22. Graphs showing climate-change results for streamgage 205406500, Black Earth Creek at the Village of Black Earth, showing average annual total streamflow time series, statistical summary, and average monthly streamflow.

23. Graphs showing climate-change results for streamgage 205406500, Black Earth Creek at the Village of Black Earth, showing average annual low streamflow...

24. Graphs showing climate-change results for streamgage 205406500, Black Earth Creek at the Village of Black Earth, showing average annual high streamflow

25. Graphs showing climate-change results for the springs area east of the Village of Cross Plains

26. Graphs showing forecast of groundwater levels for a shallow well in glacio-fluvial sediments located toward the upper portion of the watershed, a deep well open to the Mt. Simon bedrock aquifer in the upper portion of the watershed, and a well of intermediate depth open to the upper Paleozoic bedrock aquifer in the middle portion of the watershed near the Garfoot tributary 
27. Graphs showing climate-change scenario simulations showing annual average stream temperatures for upper, middle, and lower reaches of Black Earth Creek.........41

28. Graphs showing example of land use change mitigating potential future climate change

\section{Appendix Figures}

1-1. Map showing Black Earth Creek watershed MODFLOW model location, boundaries, groundwater elevation, and base flow targets

1-2. Block diagrams showing Black Earth Creek MODFLOW model layers, major hydrostratigraphic units, and stream cells.

1-3. Cross sections showing layers and zones of hydraulic conductivity used in the calibrated groundwater model.

1-4. Map showing location of the pilot points used for layers 1, 2, 3, and 5 .

1-5. Map showing recharge distribution calculated by the Soil-Water Balance approach of Westenbroek and others (2010)

1-6. Map showing Unsaturated-Zone Flow (UZF) Package IRUNBND array used to route overland flow to surface-water features.

2-1. Map showing steady-state groundwater-model results used in the parameterization process

2-2. Map showing hydrologic response units generated for the Black Earth Creek surface-water model.

2-3. Map showing overland flow routing diagram generated for the Black Earth Creek

Precipitation-Runoff Modeling System (PRMS) model

2-4. Map showing groundwater flow routing diagram generated for the Black Earth Creek Precipitation-Runoff Modeling System model

2-5. Map showing climate stations used in the Black Earth Creek Precipitation-Runoff Modeling System model.

4-1. Map showing location of weather stations operated during the project and stream-temperature sensors in the Black Earth Creek watershed

4-2. Conceptual model illustrating linear structure of stream network used in SNTEMP

5-1. Graph showing seepage run results and stream discharge along Black Earth Creek stream system

5-2. Graph showing seepage run results and stream discharge normalized by upstream watershed area.

6-1. Graphs showing solar radiation and potential evapotranspiration results for step 1 calibration, and snowpack results for step 2 calibration...

6-2. Graphs showing initial uncoupled calibration results for long-term streamgage 05406500, Black Earth Creek at Black Earth, for the log of daily streamflow, mean annual streamflow, monthly mean streamflow, and mean monthly streamflow calculated for 8 years of record

6-3. Graphs showing initial uncoupled calibration results for long-term streamgage 05427948, Pheasant Branch at Middleton, for the log of daily streamflow, mean annual streamflow, monthly mean streamflow, and mean monthly streamflow calculated for 8 years of record

6-4. Graphs showing initial uncoupled calibration results for long-term streamgage 05427948, Brewery Creek at Cross Plains, for the log of daily streamflow, mean annual streamflow, monthly mean streamflow, and mean monthly streamflow calculated for 6 years of record. 
6-5. Graphs showing initial uncoupled calibration results for one-year streamgage 054066491, Garfoot Creek near Cross Plains, for the log of daily streamflow, mean annual streamflow, and monthly mean streamflow.....

6-6. Graphs showing initial uncoupled calibration results for one-year streamgage 054065145, Vermont Creek at Highway KP, for the log of daily streamflow, mean annual streamflow, and monthly mean streamflow.

6-7. Graphs showing initial uncoupled calibration results for one-year streamgage 05406540, Black Earth Creek at Mazomanie, for the log of daily streamflow, mean annual streamflow, and monthly mean streamflow.

6-8. Graph showing observed heads compared to heads simulated by the optimal MODFLOW-only model .

6-9. Graph showing heads measured in 2005 compared to heads simulated by the optimal MODFLOW-only model.

6-10. Graph showing vertical head differences calculated using observed heads compared to vertical head differences calculated using heads simulated by the optimal MODFLOW-only model.

6-11. Graph showing average observed base flow compared to simulated base flow for entire model domain.

6-12. Graph showing average observed base flow compared to simulated base flow for Black Earth Creek headwater locations

6-13. Graph showing February 2005 observed base flow compared to simulated base flow for tributaries of Black Earth Creek

6-14. Graphs showing calibration results for long-term streamgage 05406500, Black Earth Creek at Black Earth, for the log of daily streamflow, mean annual streamflow, monthly mean streamflow, and mean monthly streamflow calculated for 8 years of record.

6-15. Graphs showing calibration results for long-term streamgage 05427948, Pheasant Branch at Middleton, for the log of daily streamflow, mean annual streamflow, monthly mean streamflow, and mean monthly streamflow calculated for 8 years of record

6-16. Graphs showing calibration results for long-term streamgage 05406470, Brewery Creek at Cross Plains, for the log of daily streamflow, mean annual streamflow, monthly mean streamflow, and mean monthly streamflow calculated for 8 years of record

6-17. Graphs showing calibration results for 1-year streamgage 05406491, Garfoot Creek near Cross Plains, for the log of daily streamflow, mean annual streamflow, and monthly mean streamflow.

6-18. Graphs showing calibration results for 1-year streamgage 054065145, Vermont Creek near Highway KP, for the log of daily streamflow, mean annual streamflow, and monthly mean streamflow

6-19. Graphs showing calibration results for 1-year streamgage 05406540, Black Earth Creek at Mazomanie, for the log of daily streamflow, mean annual streamflow, and monthly mean streamflow.

6-20. Graphs showing calibration results for 1991-2006 at Refuse Hideaway wells 36s, and $36 \mathrm{~d}$

6-21. Graphs showing calibration results for 2005-6 at Refuse Hideaway wells $32 \mathrm{~s}$, 36d, p38, and the Mount Simon deep well

6-22. Graphs showing calibration results for 2005-6 at Upper Paleozoic bedrock wells north and south 
6-23. Graphs showing mean water levels for the transient observed data and range of

water levels during the observation periods

6-24. Horizontal hydraulic conductivity along Row 80 after fully coupled model calibration, shown as a cross section without vertical exaggeration and with a vertical exaggeration of 30 .

6-25. Vertical hydraulic conductivity along Row 80 after fully coupled model calibration, shown as a cross section without vertical exaggeration and with a vertical exaggeration of 30

6-26. Maps showing horizontal hydraulic conductivity by layer after fully coupled model calibration

6-27. Maps showing vertical hydraulic conductivity by layer after fully coupled model calibration

\section{Tables}

1. Selected General Circulation Models (GCMs) and selected emission scenarios used to simulate future climate conditions

2. Final aquifer parameter values for the Black Earth Creek basin

3. Average areal precipitation and recharge rate for the Black Earth Creek model domain reported by the calibrated GSFLOW model

4. Analysis of fit between simulated and observed daily mean stream temperatures at calibration points in SNTEMP for May through September 2005

5. Quantile estimation of daily mean stream temperature with associated color-coded tolerance of brown trout (Salmo trutta) for two simulation periods and three emission scenarios at reaches BEC-015, BEC-008, and BEC-001 of Black Earth Creek compared to measured values

\section{Appendix Tables}

2-1. Parameters assumed to be related to the predominant land use within each hydrologic response unit (HRU)

2-2. Surface-water flow parameters assumed to be related to the predominant surficial glacial material in each hydrologic response unit (HRU) .....

2-3. Groundwater and soil parameters assumed to be related to the predominant surficial glacial geology within a hydrologic response unit (HRU)

2-4. Parameters generated from a multi-objective calibration exercise

2-5. National Weather Service Cooperative Observer Network (COOP) and U.S. Geological Survey weather stations used to provide input to the Precipitation-Runoff Modeling System (PRMS) model.

3-1. Hydrologic processes associated with the individual steps in the Precipitation-Runoff Modeling System (PRMS)-only calibration procedure

3-2. Parameter types used in step 1 of the calibration: solar radiation and potential evapotranspiration

3-3. Parameter types used in step 2 of the calibration: snowmelt. 
3-4. Parameter types used in step 3 of the calibration: runoff, infiltration, and groundwater flow

3-5. Precipitation-Runoff Modeling System (PRMS) parameter types estimated during calibration of the fully coupled GSFLOW model.

3-6. MODFLOW parameter types estimated during calibration of the fully coupled GSFLOW model. Parameter names that represent a single parameter do not display minimum and maximum calibrated values...

4-1. Stream geometry characteristics for stream reaches described in SNTEMP

4-2. Stream characteristics for stream reaches described in SNTEMP used to calculate stream shading.....

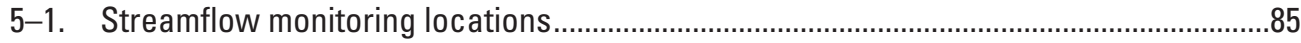

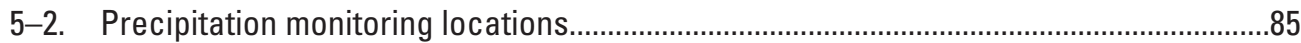

5-3. Seepage run information for February 2005.............................................................87

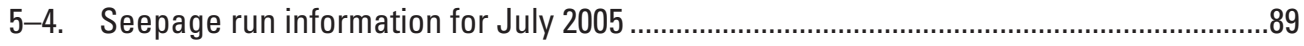

5-5. Description of sites with continuous-record groundwater levels in the Black Earth Creek watershed.

6-1. MODFLOW-only head calibration statistics. Error residual statistics or differences are calculated as observed minus simulated value.

\section{Conversion Factors}

International System of Units to U.S. customary units

\begin{tabular}{lcl}
\hline \multicolumn{1}{c}{ Multiply } & By & To obtain \\
\hline centimeter $(\mathrm{cm})$ & Length & inch (in.) \\
meter $(\mathrm{m})$ & 0.3937 & foot (ft) \\
kilometer $(\mathrm{km})$ & 3.281 & mile (mi) \\
\hline square kilometer $\left(\mathrm{km}^{2}\right)$ & 0.6214 & \\
square kilometer $\left(\mathrm{km}^{2}\right)$ & Area & acre \\
\hline & 247.1 & square mile (mi $\left.{ }^{2}\right)$ \\
\hline centimeter per year $(\mathrm{cm} / \mathrm{yr})$ & 0.3861 & inch per year (in/yr) \\
inch per year (in/yr) & Precipitation and flow rate & centimeter per year (cm/yr) \\
cubic foot per second (ft $3 / \mathrm{s})$ & 0.3937 & cubic meter per second (m $\left.{ }^{3} / \mathrm{s}\right)$ \\
\hline
\end{tabular}

Temperature in degrees Celsius $\left({ }^{\circ} \mathrm{C}\right)$ may be converted to degrees Fahrenheit $\left({ }^{\circ} \mathrm{F}\right)$ as follows:

$$
{ }^{\circ} \mathrm{F}=\left(1.8 \times{ }^{\circ} \mathrm{C}\right)+32
$$

Temperature in degrees Fahrenheit $\left({ }^{\circ} \mathrm{F}\right)$ may be converted to degrees Celsius $\left({ }^{\circ} \mathrm{C}\right)$ as follows:

$$
{ }^{\circ} \mathrm{C}=\left({ }^{\circ} \mathrm{F}-32\right) / 1.8
$$




\section{Datum}

Vertical coordinate information is referenced to the National Geodetic Vertical Datum of 1929 (NGVD 29).

The terms "altitude" and "elevation," as used in this report, refer to distance above the vertical datum.

\section{Supplemental Information}

A water year is defined as the 12-month period from October 1 through September 30 of the following calendar year, and is designated by the calendar year in which it ends.

\section{Acknowledgments}

Initial study was funded through a Wisconsin Department of Natural Resources (WDNR) River Grant obtained by the Village of Cross Plains and U.S. Geological Survey (USGS) funding. The WDNR and USGS funded the supplemental field data collection; the WDNR, USGS, Town of Black Earth, Village of Black Earth, Village of Cross Plains, Village of Mazomanie, City of Middleton, and Town of Vermont provided support for model construction, calibration, and scenario simulations. Hank Kuehling (WDNR) is thanked for providing the Refuse Hideaway groundwater data. Thanks are extended to Pete Jopke (Dane County Department of Land and Water Resources) for allowing a meteorological station to be installed on his property. We also thank Mike Sorge (WDNR) for sharing time and monitoring equipment to record stream temperatures. Richard Niswonger (USGS), Roland Viger (USGS), and Steven L. Markstrom (USGS) are acknowledged and thanked for their assistance in constructing early versions of models. The Black Earth Creek Watershed Association and Southern Wisconsin Chapter of Trout Unlimited are thanked and acknowledged for organizing public listening sessions used in model construction and design. 


\title{
Simulation of Climate Change Effects on Streamflow, Groundwater, and Stream Temperature using GSFLOW and SNTEMP in the Black Earth Creek Watershed, Wisconsin
}

\author{
By Randall J. Hunt, Stephen M. Westenbroek, John F. Walker, William R. Selbig, R. Steven Regan, Andrew T. \\ Leaf, and David A. Saad
}

\section{Abstract}

A groundwater/surface-water model was constructed and calibrated for the Black Earth Creek watershed in southcentral Wisconsin. The model was then run to simulate scenarios representing common societal concerns in the basin, focusing on maintaining a cold-water resource in an urbanizing fringe near its upper stream reaches and minimizing downstream flooding. Although groundwater and surface water are considered a single resource, many hydrologic models simplistically simulate feedback loops between the groundwater system and other hydrologic processes. These feedbacks include timing and rates of evapotranspiration, surface runoff, soil-zone flow, and interactions with the groundwater system; however, computer models can now routinely and iteratively couple the surface-water and groundwater systems-albeit with longer model run times. In this study, preliminary calibrations of uncoupled transient surface-water and steadystate groundwater models were used to form the starting point for final calibration of one transient computer simulation that iteratively couples groundwater and surface water. The computer code GSFLOW (Groundwater/Surface-water FLOW) was used to simulate the coupled hydrologic system; a surface-water model represented hydrologic processes in the atmosphere, at land surface, and within the soil zone, and a groundwater-flow model represented the unsaturated zone, saturated zone, and streams. The coupled GSFLOW model was run on a daily time step during water years 1985-2007. Early simulation times (1985-2000) were used for spin-up to make the simulation results less sensitive to initial conditions specified; the spin-up period was not included in the model calibration. Model calibration used observed heads, streamflows, solar radiation, and snowpack measurements from 2000 to 2007 for history matching. Calibration was performed by using the PEST parameter estimation software suite.

Simulated streamflows from the calibrated GSFLOW model and other basin characteristics were used as input to the one-dimensional SNTEMP (Stream-Network TEMPerature) model. SNTEMP was used to simulate daily stream temperature in selected stream reaches in the watershed. The temperature model was calibrated to high-resolution stream temperature time-series data measured in 2005. The calibrated GSFLOW and SNTEMP models were then used to simulate effects of potential climate change for the years 2010 through 2100. An ensemble of climate models and emission scenarios was evaluated. Downscaled climate drivers for the simulation period showed increases in maximum and minimum air temperature. Scenarios of future precipitation, however, did not show a monotonic trend like temperature. Uncertainty in the climate drivers increased with time for both temperature and precipitation.

Forecasts of potential climate change scenarios showed growing season length increasing by weeks, and both potential and actual evapotranspiration rates increasing appreciably, in response to increasing air temperature. Simulated actual evapotranspiration rates increased less than simulated potential evapotranspiration rates as a result of water limitation in the root zone during the summer high-evapotranspiration period. The hydrologic-system response to climate change was characterized by a reduction in the importance of the snowmelt pulse and an increase in the importance of fall and winter groundwater recharge. The less dynamic hydrologic regime is likely to result in drier soil conditions, with relatively less drying expected in groundwater-fed systems. Groundwater discharge in the current upper cold-water reaches of Black Earth Creek is expected to decrease; flooding in downstream reaches may appreciably increase. The magnitude of changes in forecasted flow and associated groundwater/surface-water interaction is dependent on the General Circulation Model and emission scenario chosen.

Potential future changes in air temperature drivers were consistently upward regardless of General Circulation Model and emission scenario selected; thus, simulated stream temperatures are forecast to increase appreciably with future climate. However, the amount of temperature increase was variable. Such uncertainty is reflected in temperature model results, along with uncertainty in the groundwater/surface-water interaction itself. The estimated increase in annual average temperature ranged from approximately 3 to 6 degrees Celsius by 2100 in the upper reaches of Black Earth Creek and 2 to 
4 degrees Celsius in reaches farther downstream. As with all forecasts that rely on projections of an unknowable future, the results are best considered to approximate potential outcomes of climate change given the underlying uncertainty.

\section{Introduction}

Although groundwater and surface water are considered a single resource (Leopold, 1974; Winter and others, 1998), hydrologic simulations typically do not explicitly couple the two systems to reduce time and effort. Groundwater and surface-water models can be loosely linked outside of the models without modifying the underlying computer codes (Hunt and Steuer, 2000; Steuer and Hunt, 2001), but then only timeaveraged or long-term simulations are meaningful, and such simulations may not include enough inter-annual characteristics and related system dynamics to be useful for many waterresources decisions. More computationally expensive coupled hydrologic models, however, can include various hydrologic feedback pathways and therefore can more fully encompass the processes and related dynamics that may exacerbate or mitigate the effect of potential future hydrologic stress. These processes include the timing and rates of evapotranspiration, surface runoff, soil-zone flow, recharge, and interactions with the stream network and groundwater system.

The "coupled-regions" approach was implemented in GSFLOW (Groundwater/Surface-water FLOW) (Markstrom and others, 2008). GSFLOW is an integration of the U.S. Geological Survey (USGS) Precipitation-Runoff Modeling System (PRMS; Leavesley and others, 1983; Leavesley and others, 2005; Markstrom and others, 2015) with versions of the USGS Modular Groundwater Flow Model MODFLOW-2005 (Harbaugh, 2005) and MODFLOW-NWT (Niswonger and others, 2011). In GSFLOW, separate equations are coupled to simulate (1) horizontal and vertical flow above land surface and through the soil zone; (2) gravity-driven, vertical flow through the unsaturated zone; and (3) three-dimensional groundwater flow through the saturated zone. GSFLOW uses physically based processes and empirical methods with user inputs of air temperature and snow/rain precipitation to simulate the distribution of precipitation into throughfall, snowmelt, surface runoff, evapotranspiration, infiltration, groundwater flow, and surface-water flow. Because of its computational efficiency, GSFLOW can be applied to watershed-scale problems ranging from a few square kilometers to several thousand square kilometers and for time periods that range from months to several decades (Markstrom and others, 2008).

Decisions regarding the appropriate level of model simplification are facilitated by consideration of the model predictions of interest (Hunt and others, 2007; Anderson and others, 2015). Such predictions often include not only water flows but also other relevant ecohydrological end-members that decision makers are charged with managing (Hunt and Wilcox, 2003; Hancock and others, 2009). The objectives for the model described herein included forecasts of the effects of climate-change scenarios on the cold-water fishery, which is influenced by streamflow, groundwater/surface-water interaction, and stream temperature. Therefore, streamflow results from the coupled GSFLOW model were linked to an SNTEMP model (Stream-Network TEMPerature; Bartholow, 1991), a steady-state, one-dimensional heat transport model that predicts daily mean maximum and minimum temperatures as a function of distance along the stream and environmental heat flux. This approach allows simulations of propagation of potential temperature changes in the atmosphere to cold-water streams and associated fisheries.

\section{Purpose and Scope}

The purpose of this work was to construct a tool for forecasting potential streamflows and stream temperature under different climates and land use. This report describes the construction, calibration, and scenario testing of a GSFLOW coupled groundwater and surface-water model and SNTEMP stream-temperature model for the Black Earth Creek (BEC) watershed in south-central Wisconsin (fig. 1). The GSFLOW model simulates atmospheric, surface, and subsurface elements of the hydrologic cycle including rainfall, snowmelt, evapotranspiration, interflow, streamflow, base flow, and groundwater flow. Coupled groundwater/surface-water flow output was used to construct the stream-temperature model. The calibrated hydrologic/stream-temperature models were then used to simulate potential climate-change effects on streamflow, groundwater/surface-water interactions, and stream temperature.

The study developed a quantitative tool to simulate historic, current, and potential future streamflows and stream temperatures in the BEC watershed. Because the streamflow and issues related to streamflow are a function of groundwater and surface water, the focus is on the coupled groundwater/ surface-water system. The coupled flow model outputs were linked to an associated stream-temperature model to characterized drivers important for stream ecology (Novitzki, 1973; Hunt and others, 2006).

The report includes (1) a brief description of construction and calibration of the coupled groundwater-flow and surfacewater flow model, (2) considerations required by coupled modeling as compared to uncoupled simulations, (3) construction and calibration of a stream-temperature model that uses results from the calibrated coupled groundwater/surface-water model, and (4) forecasts of streamflow and groundwater/ surface-water interaction changes for a set of potential climate scenarios. Appendixes are included to give a more extensive presentation of model construction and calibration approaches (appendixes 1-4), data-collection (appendix 5), and calibration results (appendix 6). The groundwater/surface-water and stream-temperature models were constructed by using daily or larger time increments; thus, "continuous" or "storm-mode" simulations of individual storm events were not in the scope of 


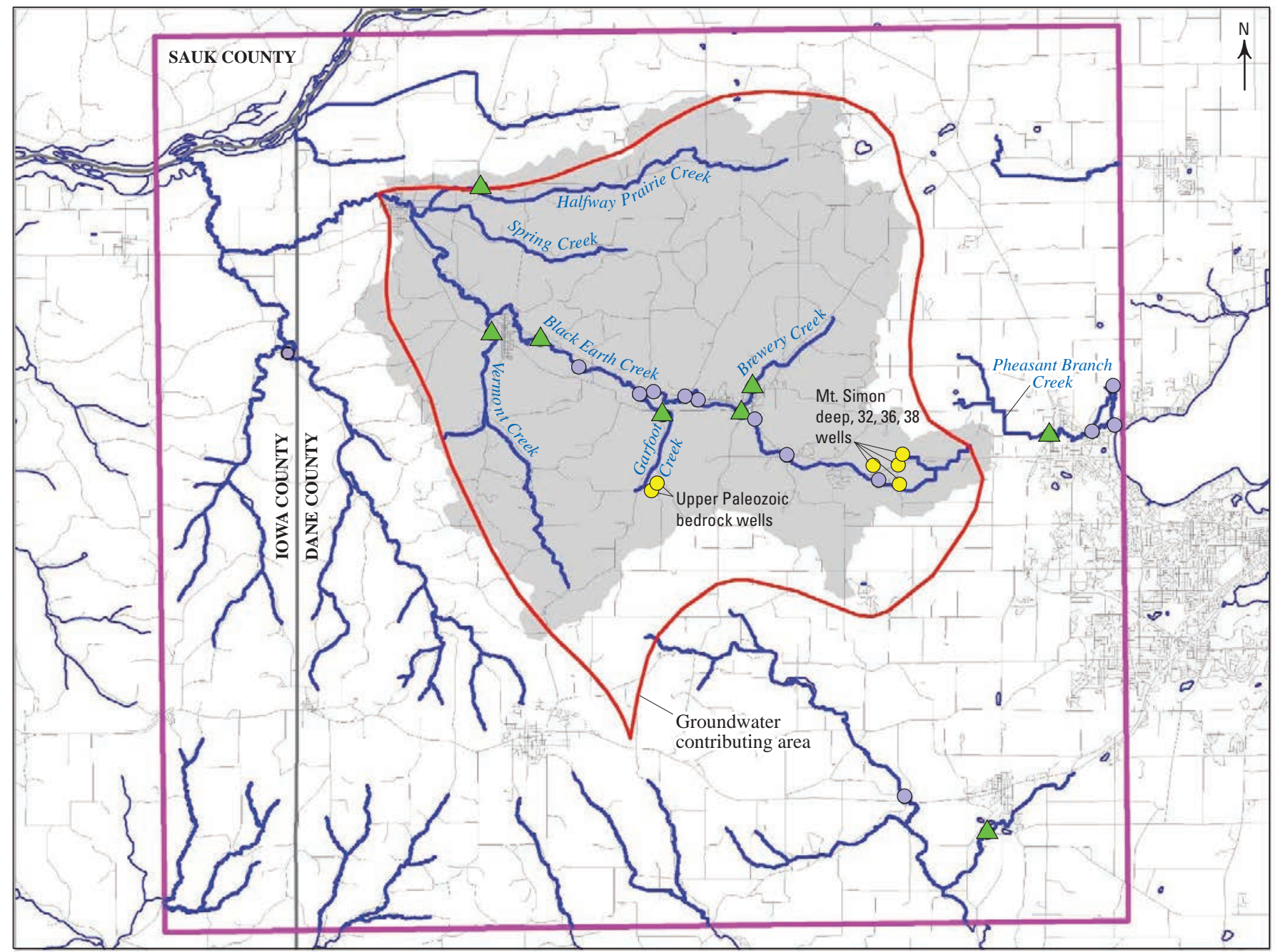

Base from Wisconsin Department of Natural Resources, 1998, 1:24,000 Referenced to the Wisconsin Transverse Mercator coordinate system of 1983 based on the 1991 adjustment to the North American Datum of 1983 (WTM83, NAD83 [1991])

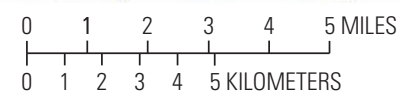

EXPLANATION
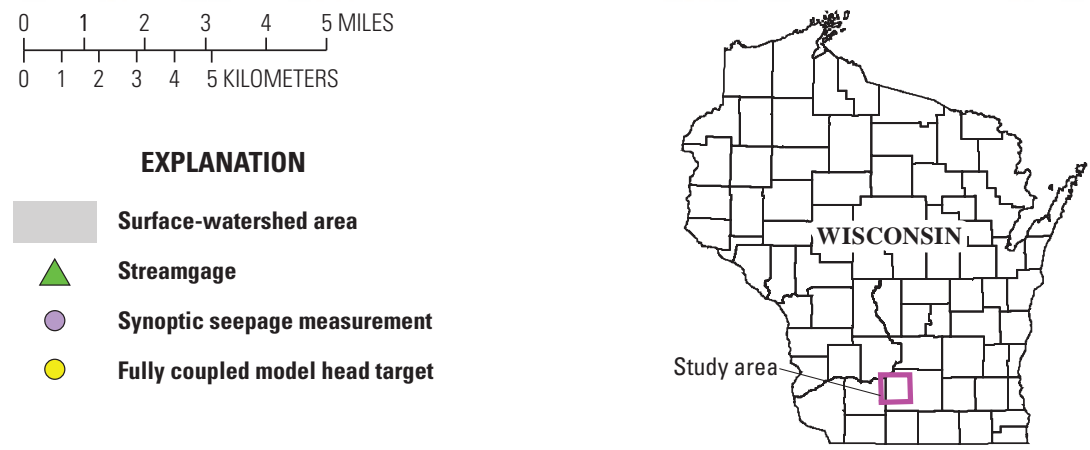

Figure 1. The Black Earth Creek groundwatershed and surface watershed, Dane County, Wisconsin. 
this work. In addition, because the quantitative tool was developed on the basis of watershed flows and not local hydraulic characteristics at any one location in the watershed, model results are reported as streamflow (discharge) and not local stream stage or flood peak.

\section{Site Description and Hydrologic Setting}

The BEC watershed (fig. 1) is 27 miles long and drains 103 square miles. The watershed is located in a humid, temperate climate and includes tributary streams (fig. 2) that encompasses both glaciated and unglaciated areas of Dane County, Wisconsin (fig. 3). The conceptualization of the BEC area was derived from existing work, including bedrock geology (Brown and others, 2013), glacial geology (Clayton and Attig, 1997), hydrogeologic framework (Bradbury and others, 1999; Swanson, 1996), and existing models of the area (McGrath, 1991; Krohelski and others, 2000, 2002; Hunt and Steuer, 2000). From land surface downward, the geology of the glaciated portion of the watershed was simplified by Hunt and Steuer (2000) as follows:

- a thin, overlying unconsolidated sedimentary sand and gravel aquifer that is Quaternary in age;

- an upper bedrock aquifer consisting primarily of Cambrian sandstones and Ordovician carbonates that is absent under Lake Mendota but can be as thick as 625 feet in western Dane County (the average thickness in the BEC watershed is 385 feet);

- a shaly confining unit (the Eau Claire shale) that is absent near Lake Mendota and is as thick as 70 feet elsewhere (the average unit thickness in the BEC watershed is 31 feet);

- an extensive lower bedrock aquifer that consists of a Cambrian sandstone aquifer (Mount Simon and Eau Claire sandstone) that ranges between 400 and 700 feet and averages 540 feet thick in the BEC watershed area; and

- an impermeable Precambrian crystalline bedrock basement.

The unglaciated part of the BEC basin is similar but is characterized by sand and gravel in the valleys and a thin layer of wind-blown silt (loess) as the uppermost unit in the uplands (Clayton and Attig, 1997). The glaciated areas have less topographic relief than the unglaciated areas; topographic relief in the unglaciated areas can be as much as 430 feet. The water table is commonly present in the unconsolidated sediments in the glaciated portion of the BEC watershed and in the Upper Paleozoic bedrock layer in the unglaciated BEC area. High-capacity wells are typically completed in the Paleozoic bedrock, and in some cases wells are open to both the upper and lower bedrock aquifers.

The surface-water watershed consists of a main stem and five primary tributaries: Brewery, Garfoot, Vermont, Halfway Prairie, and Spring Creeks (fig. 1). Black Earth Creek itself flows west and north into Blue Mounds Creek, a tributary to the Wisconsin River and, ultimately, the Mississippi River. The BEC watershed is generally hilly and has steep-sided valleys, especially in the unglaciated portion of the watershed; however, the floor of the main valley between the villages of Cross Plains and Black Earth is nearly flat and about one-half mile wide. The headwater drainage network of the watershed has been significantly modified during the last 100 years, including draining portions of a large wetland east to Lake Mendota (Maher, 1999). Prior to the turn of the 20th century, the headwater wetlands drained into the BEC watershed to the west. Previous work has described the adjacent Pheasant Branch Creek basin to the east (Krug and Goddard, 1986; Hunt and Steuer, 2000; Steuer and Hunt, 2001; Hunt and Steuer, 2001). The BEC groundwater basin is larger than the surface-water basin primarily because of contributions from the adjacent Sugar River basin to the south (Cline and Busby, 1963).

\section{GSFLOW Groundwater/Surface-Water Modeling Approach}

Hydrologic forecasts of interest for this report include (1) streamflow, (2) groundwater flow and its relation to streams, and (3) basin water residence and travel time. Groundwater and surface water are considered a single resource, and the groundwater/surface-water code used here is a fully coupled hydrologic model that includes hydrologic feedbacks and fully encompasses the processes and related dynamics that may exacerbate or mitigate the effect of hydrologic stress such as climate variability and land use change. These processes include timing and rates of evapotranspiration, snowmelt, surface runoff, soil-zone flow, and interactions with the groundwater system. Because a fully coupled model can have long runtimes, uncoupled models of the groundwater and surface-water system were constructed before the fully coupled model calibration, as described below.

The GSFLOW computer code documented by Markstrom and others (2008) couples separate equations to simulate horizontal and vertical flow through the soil zone, gravity-driven vertical flow through the unsaturated zone, and three-dimensional groundwater flow through the saturated zone. GSFLOW was designed to simulate the most important processes using numerically efficient algorithms, thus allowing coupled simultaneous simulation of flow in and across one or more watersheds. GSFLOW incorporates physically and empirically based methods for simulating runoff and infiltration from snow and rain precipitation and groundwater/surface-water interaction. GSFLOW is intended 


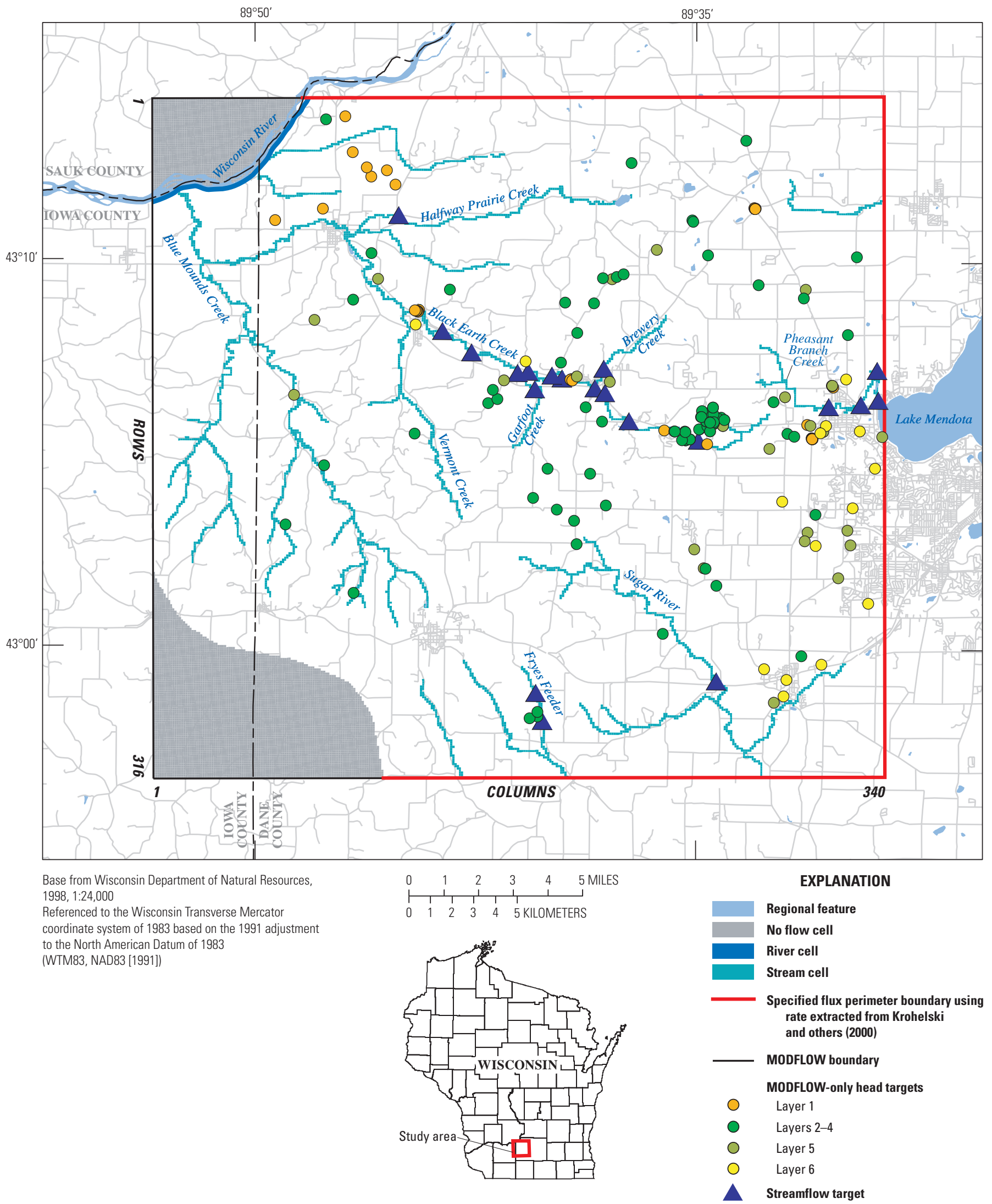

Figure 2. The Black Earth Creek model grid, boundary conditions, and calibration targets. 
Simulation of Streamflow, Groundwater, and Stream Temperature in the Black Earth Creek Watershed

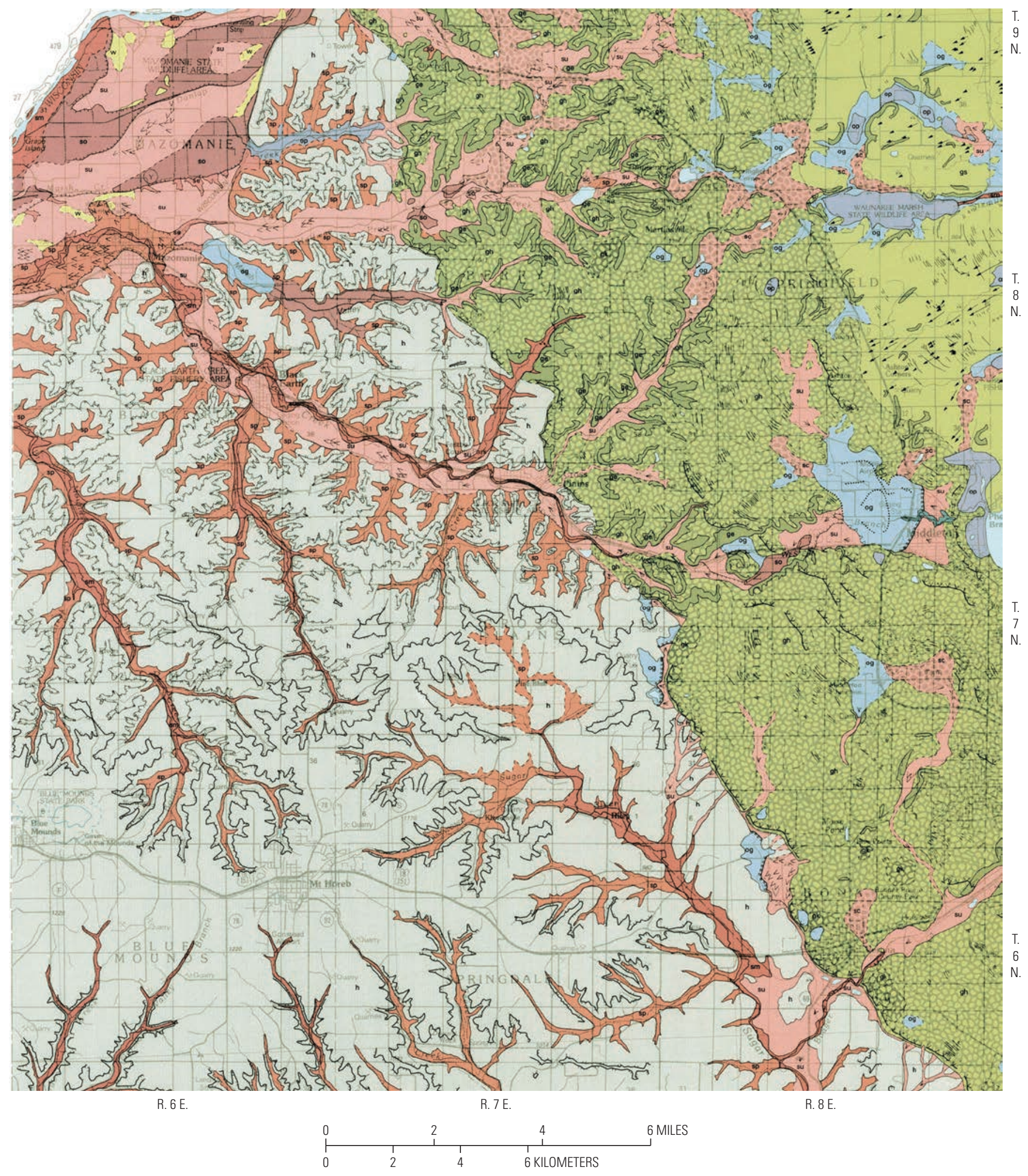

Figure 3. Pleistocene geology of the Black Earth Creek watershed model domain (from Clayton and Attig, 1997). 


\section{EXPLANATION}
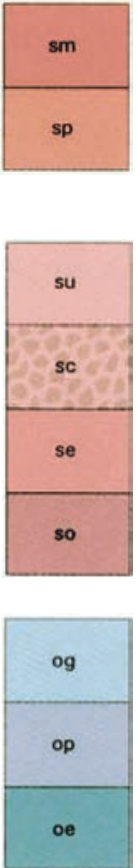

Offshore lake sediment-Plane-bedded and cross-bedded sand and planebedded silt and clay; also includes some near-shore gravel; typically 1 meter to tens of meters thick; deposited during the Wisconsin Glaciation; part of the Horicon Member of the Holy Hill Formation; in places overlain by several meters of postglacial offshore sediment, including bioturbated silt and clay (with some organic material) and marl (with mollusk shells). Unit og: mostly uncollapsed, with flat topography; some deposited on stagnant ice, resulting in slightly hummocky topography. Unit op: overlain by a few meters of postglacial peat; flat topography. Unit oe: eroded offshore sediment; gullied topography is the result of erosion in postglacial time.

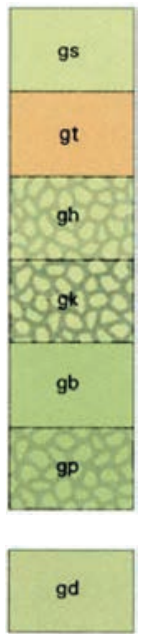

Till-Gravelly, clayey, silty sand deposited by the Green Bay Lobe generally at least a few meters thick; part of the Horicon Member of the Holy Hill Formation; includes many small to large inclusions of meltwater-stream sediment and glacial-lake sediment that could not be separately mapped. Unit gs: uniform subglacial till deposited during the last part of the Wisconsin Glaciation; smooth, streamlined topography with drumlins. Unit gt: similar to unit gs, but underlain at shallow depth by meltwater-stream sand and gravel. Unit gh: nonuniform collapsed supraglacial till and sorted supraglacial debris deposited during the last part of the Wisconsin Glaciation; slightly hummocky topography. Unit gk: similar to unit gh, but more hummocky. Unit gb, nonuniform supraglacial till and sorted supraglacial debris deposited during the Brooklyn Phase of the Wisconsin Glaciation; nondescript glacial topography. Unit gp: similar to unit gb, but hummocky.

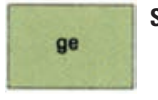

Steep eroded slopes in glaciated areas-Includes areas gullied in postglacial time, eliminating glacial topography; a variety of materials, including till, dolomite, and sandstone, is exposed at the top of the slopes; fans of hillslope sediment cover the lower parts of the slopes; many of these slopes previously were scarps along the sides of preglacial valleys.

Hillslopes underlain by early Paleozoic rock in the unglaciated areaIncludes dolomite on the uplands, sandstone in the scarps at the edge of the uplands, and shale in Blue Mounds. Rock is generally overlain by a few meters of red-tinged clay or sand of the Rountree Formation, which in turn is overlain by 1 meter or less of windblown silt of the Kieler Formation; rubble consisting of material derived from the Paleozoic formations and from the Rountree and Kieler Formations has accumulated on the lower flanks of the steeper slopes. Probably includes areas that have been glaciated (but evidence is scarce or lacking) in the south-central part of the county.

Figure 3. Pleistocene geology of the Black Earth Creek watershed model domain (from Clayton and Attig, 1997).-Continued

for watershed-scale problems that can range from a few square kilometers to several thousand square kilometers, and for time periods that range from months to decades (Markstrom and others, 2008). Before the fully coupled model was run, however, uncoupled models of the groundwater and surface-water system were constructed and are described below.

\section{Brief Description of Groundwater Model Construction}

The groundwater model construction methods followed those described by Hunt and Steuer (2000), and are described briefly here and in detail in appendix 1 . An inset model was extracted from a MODFLOW (Harbaugh, 2005) model (fig. 1) constructed for Dane County (Krohelski and others, 2000). The model was run both in steady state for uncoupled calibration, and in sequential steady state and daily time-step transient mode for fully coupled calibration. The county-scale output was used to assign constant flux boundary conditions along the perimeter of the inset model (fig. 2) and the inset model grid was refined using a telescopic mesh refinement (TMR; Ward and others, 1987). The original grid spacing was $1,312.4$ feet on a side; the refined grid is one-fourth the spacing, or 328.1 feet (100 meters) on a side. Thus, every countyscale model node is represented by 16 nodes in the TMR model. Unconsolidated deposits (sand and gravel aquifer, layer 1) were also refined (fig. 1-3) following the Pleistocene geology of Dane County (Clayton and Attig, 1997). The Upper Bedrock aquifer was divided into four layers that represent more detailed hydrogeologic units and features important for simulating groundwater flow in the basin (Anderson, 2002).

In the TMR model of the BEC watershed, selected MODFLOW packages were converted to other packages suitable for GSFLOW. All streams in the TMR model domain from the MODFLOW River (RIV) Package (Harbaugh, 2005) were converted to the more sophisticated Streamflow Routing Package (SFR2; Niswonger and Prudic, 2005), which allows for better accounting of streamflow and limits the amount of water a stream can lose to the aquifer to the amount of water 
captured upstream. Moreover, the GSFLOW code used does not support the RIV Package used in the original county model of Krohelski and others (2000). The General Head Boundary and Constant Head formulations were used to simulate Lake Mendota (east perimeter boundary) and the Wisconsin River (west and north perimeter boundary), respectively, because neither routing nor the ability to control infiltration quantities were required for these features.

Recharge added to the groundwater system was derived from a soil-water balance approach (Westenbroek and others, 2009) for the MODFLOW-only model calibration; internal recharge calculations within GSFLOW were used for the fully coupled model calibration. The Unsaturated Zone Flow (UZF) Package (Niswonger and others, 2006) was used to handle recharge in place of the Recharge Package used by Krohelski and others (2000). The UZF Package routes water through an assumed homogeneous unsaturated zone using a one-dimensional kinematic wave approximation to Richards' equation that ignores capillary forces, and can partition infiltration into evapotranspiration, runoff, unsaturated zone storage, and recharge. Hunt and others (2008) note two capabilities of the UZF Package that are notable for model calibration. First, water that leaves the root zone is routed through the unsaturated zone to the water table rather than being directly applied to the water table, which allows simulation of lags and mixing between infiltration events leaving the root zone before becoming water table recharge. Second, the UZF Package can generate and route runoff to surface-water features in areas where groundwater is at or near land surface, or during periods when the infiltration rates exceed the ability of the soil to transmit the water. This capability allows more realistic simulations of groundwater/surface-water interaction dynamics and is superior to simulating overpressurization of the groundwater system that can result from direct application of infiltration to the water table (Hunt and others, 2008).

Other changes to county-scale parameters included adding more layers to represent the aquifer (six layers in the TMR compared to three in the county-scale model) and estimation of associated additional horizontal $\left(\mathrm{K}_{\mathrm{h}}\right)$ and vertical $\left(\mathrm{K}_{\mathrm{v}}\right)$ hydraulic conductivity parameters. The original upper bedrock aquifer was divided into three layers representing upper bedrock (TMR layers 1 through 3 ) and one layer representing the Wonewoc sandstone (TMR layer 4). The most notable change is the addition of the preferential flow path (PFP) in the Tunnel City portion of the upper bedrock aquifer in a portion of layer 2 of the TMR model (fig. 1-3). The presence of the PFP has been documented in Dane County by Swanson (2001) and Anderson (2002), among others. The bottom of the PFP zone was located 35 feet above the Wonewoc contact, following the methodology of Anderson (2002). The PFP zone was terminated near the edge of glaciation because it is likely this zone was enhanced by high pressures associated with glaciation. Additionally, although the county-scale model used a quasi-three-dimensional approach for simulating the Eau Claire shale confining unit (Krohelski and others, 2000), the TMR model used individual layers for the Wonewoc sandstone (layer 4), the Eau Claire confining unit (layer 5), and the bottom-most Mt. Simon sandstone (layer 6). Finally, the number of parameters used in the inset groundwater model calibration was appreciably higher than used during previous regional modeling (see appendixes 1 and 3).

\section{Brief Description of Surface-Water Model Construction}

The surface-water system was simulated using the Precipitation-Runoff Modeling System (PRMS) on a daily time step. Development of a surface-water model begins with geographic datasets as the basis for generation of model subareas and parameters. An overview of model construction and parameterization is given below, with more detail contained in appendix 2.

\section{Construction}

The surface-water model for the adjacent Pheasant Branch basin (Steuer and Hunt, 2001) formed an initial starting point for construction and parameterization of the Black Earth Creek surface-water model. The GSFLOW code, however, represents an appreciable increase in the simulation capability. For example, unlike the original PRMS model, the PRMS-only mode of GSFLOW includes mechanisms for routing surface and shallow subsurface flow between adjacent areas of the model domain; water generated on a hilltop may be routed down an adjacent hillslope, over a flood plain, and finally to a stream segment. Thus, the model extended and refined the original approach. Description of the theoretical basis and construction details for the extended PRMS-only model available in GSFLOW is provided by Markstrom and others (2015).

\section{Hydrologic Response Units}

The surface-water modules included in the GSFLOW framework require that the model domain be split into discrete subareas, known as hydrologic response units (HRUs). Each HRU typically shares similar characteristics, such as slope, vegetation, land use, or soil type. The initial HRU configuration was generated by use of the geographic information system (GIS) Weasel (Viger and Leavesley, 2007). The final configuration of the model HRUs was achieved by manipulation of several geographic datasets within the GIS software.

The 30-meter digital elevation map (DEM) of Wisconsin (U.S. Geological Survey, 2004a) was clipped, rotated, and resampled to coincide with the bounds of the groundwater model grid (see appendix 2 for details on the grid rotation). The GIS Weasel was used to process the DEM by filling sinks and generating flow-direction and flow-accumulation grids, which were used to generate a stream network and an initial 
HRU map. To account for differences between surface-water and groundwater contributing areas, the initial HRU map was split along the approximate groundwater divide boundaries (Bradbury and others, 1999). In parts of the Black Earth Creek watershed, the degree of divergence between the surfacewater and groundwater contributing area boundaries can be several miles; the HRUs were constructed to encompass the groundwatershed and the surface watershed. Because stakeholders in the watershed expressed interest in using the model to evaluate the effect of stream buffers on hydrologic issues, the HRU map was further modified to incorporate 200-meter buffers on either side of identified major stream channels. To make the average HRU size small enough for simulations involving land use changes, the model domain was split into 780 HRUs (fig. 4). The red outline in figure 4 represents the approximate groundwater contributing area for the BEC watershed.

\section{Surface-Water Routing}

The PRMS model allows for surface flow to be routed to downslope HRUs. Each connection between a pair of HRUs or between an HRU and a stream segment must be specified explicitly. These connections were generated using the GIS Weasel (Viger and Leavesley, 2007). The resulting overland flow routing map contains 620 connections (fig. 5).

The PRMS model contains hundreds of user-specified parameter values that can be used to tailor the model to the specific area of study. Initial parameter values were generated by means of a custom script written in the R statistical programming language (R Development Core Team, 2015). The R script uses most of the methods of the GIS Weasel (Viger and Leavesley, 2007). The GIS Weasel was developed to assist in generating model parameter values for PRMS and GSFLOW models; a project-specific DEM was used to generate HRUs and some model parameters, whereas general, nationwide soils and land use GIS datasets were used to generate other parameter values. The $\mathrm{R}$ script was developed to make use of the more detailed GIS data available for the project area. In particular, some of the routines in the GIS Weasel were modified to make use of Pleistocene geology and soils mapping information available for the project area. Parameterization methods that differ significantly from Viger and Leavesley (2007) are described in appendix 2.

The PRMS model uses climate data as input to drive the hydrologic system. Daily values of precipitation and air temperature (maximum and minimum) are required inputs. Values of solar radiation and potential evapotranspiration can be either input as specified data or calculated by the model. For this study, we chose to calculate these quantities using the cloud-cover solar-radiation and Jenson-Haise potential evapotranspiration methods (appendix 2).

Data from a total of 26 precipitation stations and 19 air temperature stations were supplied to PRMS to simulate the hydrology of Black Earth Creek. The precipitation stations were either part of the USGS streamgaging network, or were part of the National Oceanic and Atmospheric Administration's (NOAA) Cooperative Observer Network (COOP) program. Air temperature stations were from the NOAA COOP program. In addition, a cooperator who lives in Mazomanie contributed data from a weather station situated on their property (appendix 5). A complete list of these stations is given in appendix 2 and the stations are shown in figure 6 .

In a temperate climate, the growing season determines the period of evapotranspiration. The beginning and end of the growing season for the calibration period were preprocessed by using an algorithm described in Christiansen and others (2011) and documented in Markstrom and others (2015). An assumed killing-frost daily temperature of -2.2 degrees Celsius $\left({ }^{\circ} \mathrm{C}\right)$, or 28 degrees Fahrenheit $\left({ }^{\circ} \mathrm{F}\right)$, was used for each HRU. During model calibration, the growing season beginning and end dates for each HRU were determined as average values for the calibration period.

\section{Calibration}

The PRMS model contains numerous parameters that cannot be estimated directly; these parameter values were set to recommended default values. Departures from default values were made on the basis of their effectiveness at reducing the difference between simulated and observed values during calibration. Geographic datasets were used to directly estimate some HRU-based parameters. Because the ultimate goal of this work was to develop a fully linked groundwater/ surface-water model, the geographic datasets used were first resampled to the resolution of the underlying groundwater model; that is, from the 30-meter DEM grid to the 100-meter MODFLOW grid. In addition, because the groundwater model grid was rotated (0.65 degrees, counter-clockwise), the geographic datasets were rotated so that they corresponded to the groundwater modeling grid used in the original Dane County Regional Model of Krohelski and others (2000).

Issues with surface-water calibration are well documented; one such issue is that only a handful of the many parameters that may be employed by a surface-water (or coupled) model are actually estimable on the basis of most calibration datasets (for example, Beven and Freer 2001, Beven and Binley, 1992). This issue suggests that, although more processes can be included in the code, the ability to constrain the parameters needed to employ the additional functionality may not be commensurate; thus, a "stepwise" calibration approach was used in the modeling. PEST parameter estimation software (Doherty, 2014a) was used to perform multiple estimation steps, with a different set of parameters and a different objective function for each step in the process, similar to that outlined by Hay and Umemoto (2007); thus, parameters estimated depended on the calibration stage, and those parameters not estimated in that calibration stage were fixed (see appendix 3 for more details). 

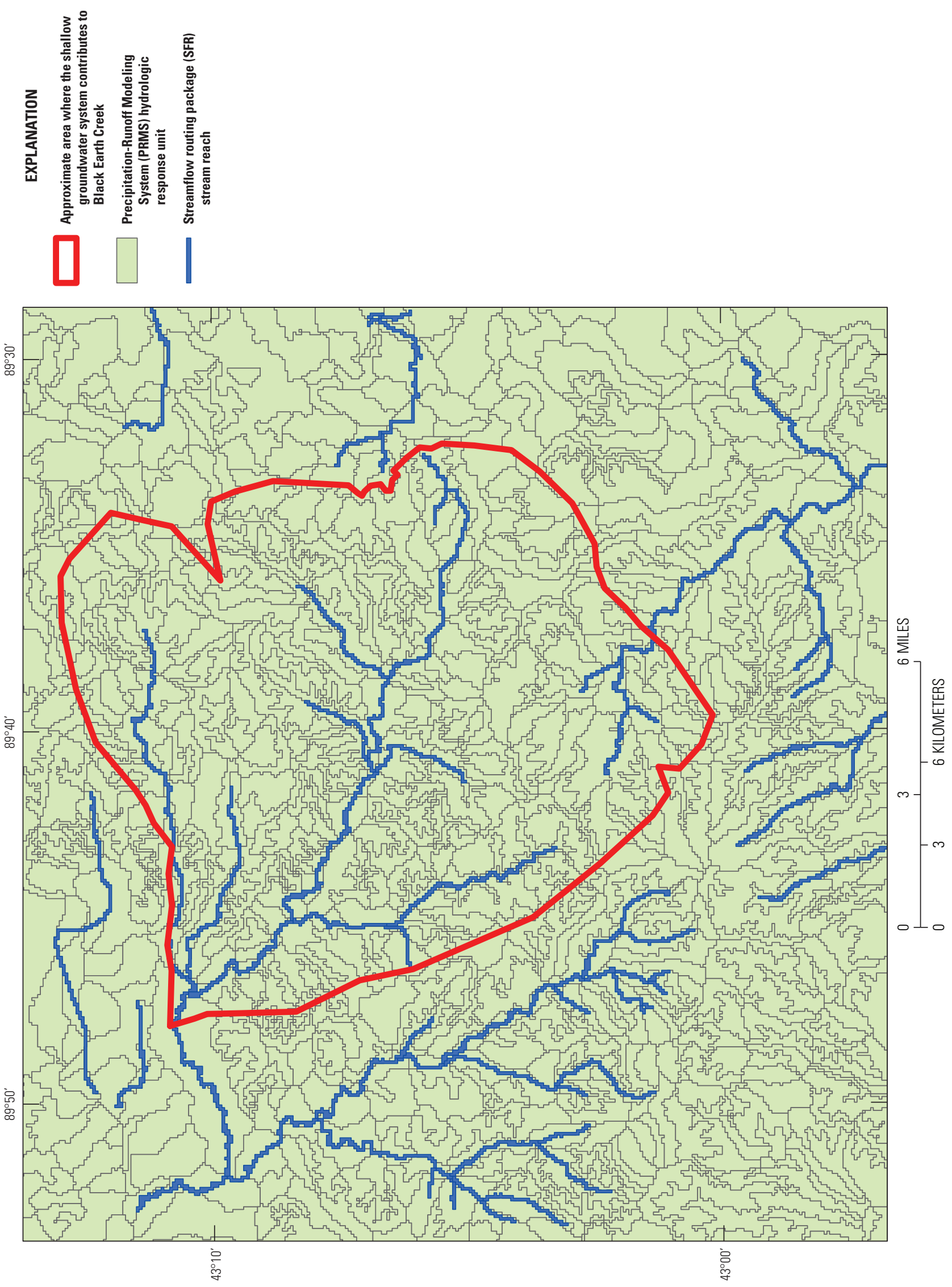

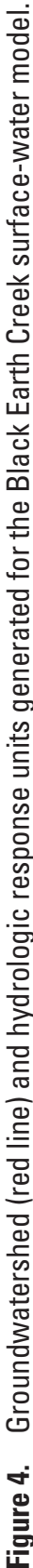



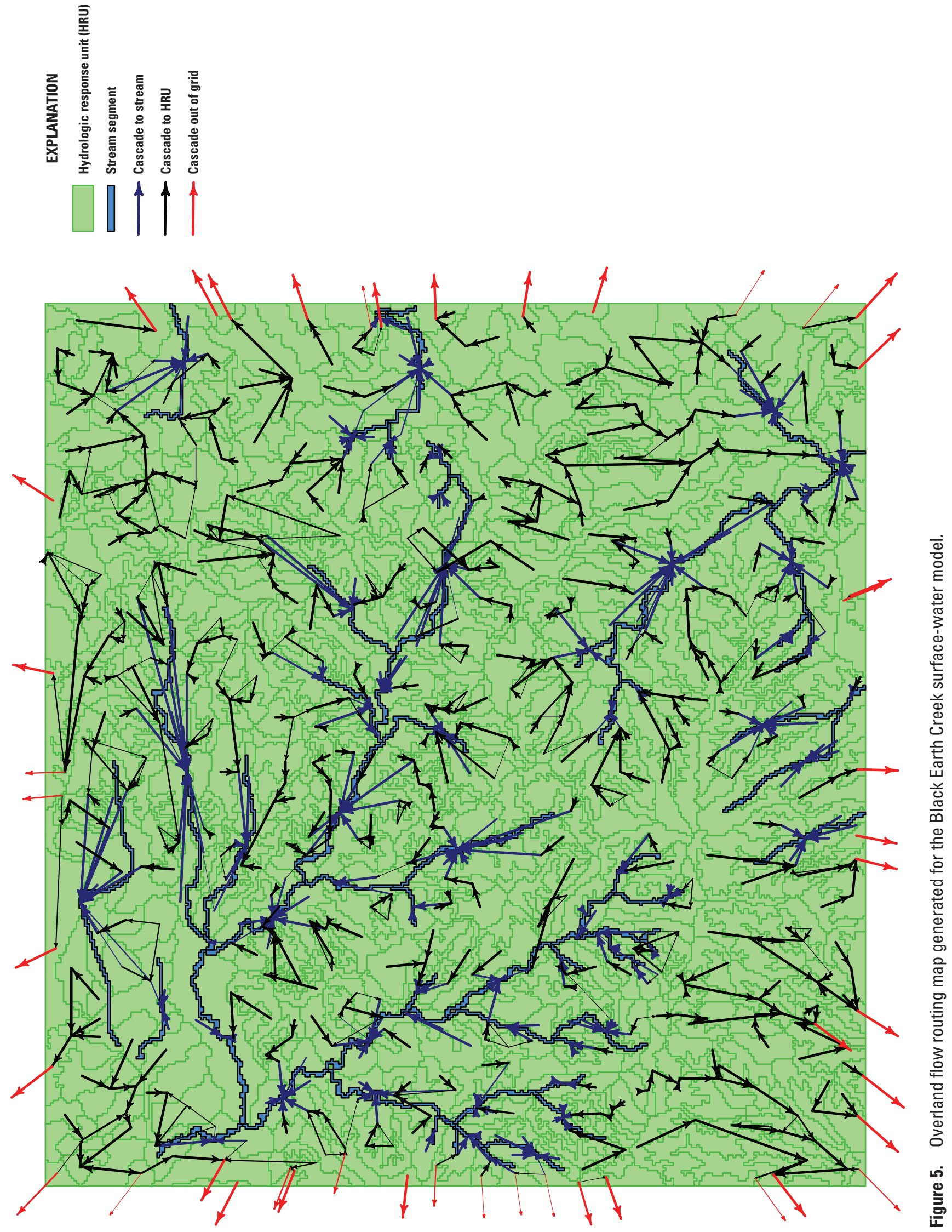


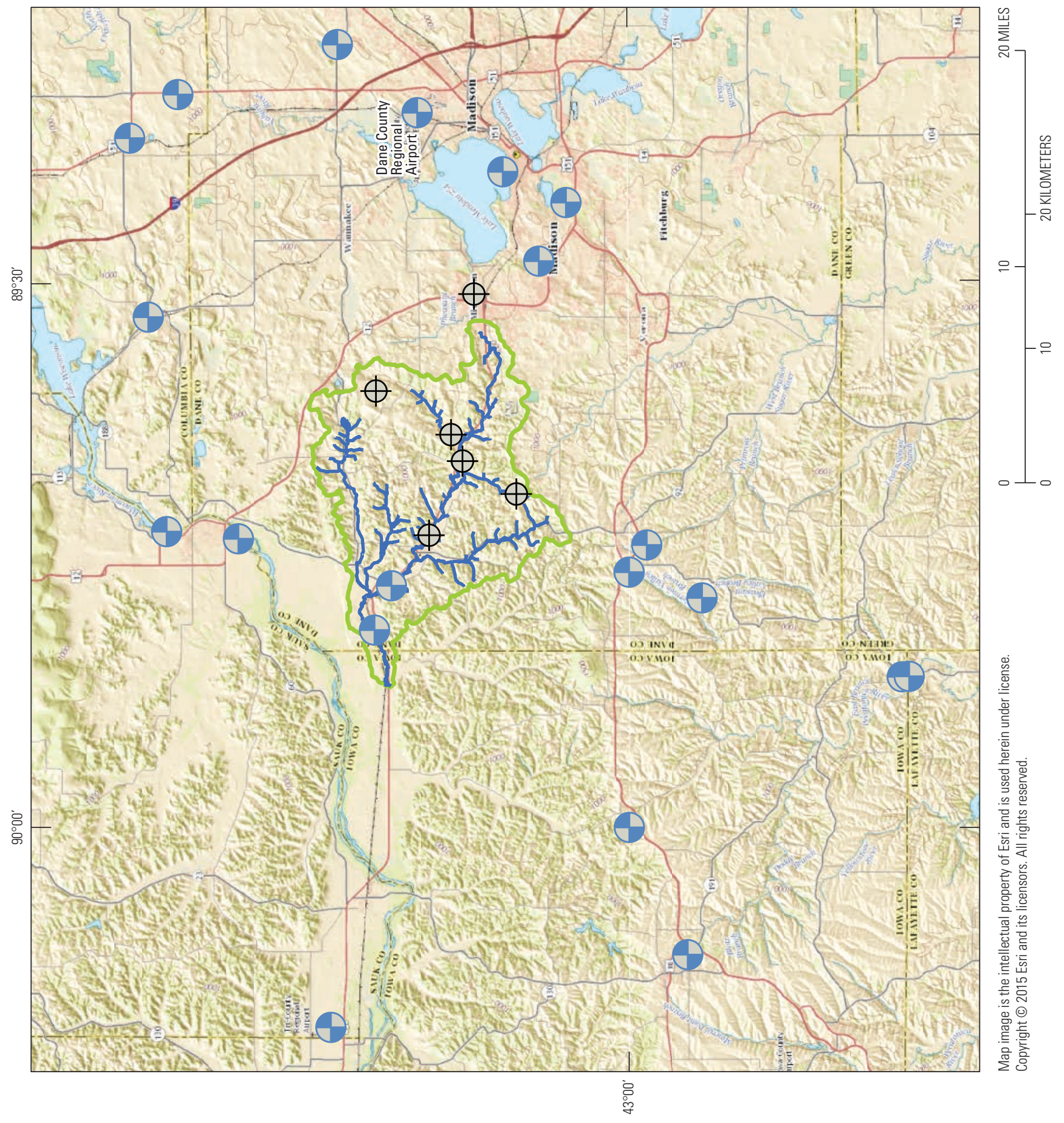

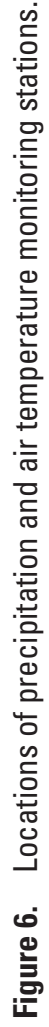




\section{Considerations for Designing a Coupled Groundwater/Surface-Water Model}

Many watershed numerical models are developed for mountainous areas and define the watershed of interest as that delineated by surface topography. Although such models are acceptable for many high-relief settings, they are problematic for many areas where the groundwatershed and surface watershed may not align (Hunt and others, 1998; Winter and others, 2003). In low-relief terrain such as that of the Midwest United States, surface-water and groundwater divides can differ from one another; such a misalignment of the groundwatershed and surface watershed was noted in the BEC basin by Cline and Busby (1963), who estimated that the BEC groundwatershed was around 10-15 percent larger than the BEC surface watershed. Therefore, unlike uncoupled models, the simulated watershed of interest in a coupled model includes the extents of the surface watershed and groundwatershed. The groundwatershed, however, is not easily delineated with field measurements in most cases; thus, a larger groundwater-flow model is commonly used to solve for physically based perimeter boundaries for a smaller inset model of the groundwatershed.

The edges of the inset model should be sufficiently distant from the nearfield area of interest such that it is shielded from artifacts from the coarse regional representation of the flow system. This inset approach results in (1) an overall domain for the coupled model that is a rectangular grid typical of a MODFLOW model rather than the irregular shape typical of a surface-water model, and (2) a groundwater domain that is larger than the surface watershed because the rectangular grid includes the entire groundwater and surface watershed for the watershed of interest, as well as areas needed to simulate perimeter watershed boundaries appropriately. This larger extent itself is not problematic because GSFLOW is designed to simulate adjacent watersheds; however, this can confound simple representations of model output because GSFLOW currently reports a total mass balance for the entire model domain.

Finally, the natural system has a hydrologic "memory" that retains the effects of antecedent climatic and hydrologic conditions that preceded the simulation start date, related in part to the periodicity of the stressors and the hydraulic diffusivity of the system. To account for the effect of conditions occurring before the simulated period of interest, a model initialization or "spin-up" period is used. During the spin-up period, representative model inputs are used to generate a dynamic equilibrium that is more representative of actual conditions at the start of the period of interest. The uncoupled surface-water (PRMS-only) mode of GSFLOW commonly uses a 1-year spin-up that is well suited for simulating observations with short hydrologic memory, such as snowpack accumulation (Hunt and others, 2009), which is completely reset to zero (completely melted) in temperate climates each year. The uncoupled surface-water model also uses linear groundwater reservoirs (that is, the groundwater system responds to change in a linear fashion) for simulating the groundwater system, which are also suited for a 1-year model spin-up.

The groundwater component of the fully coupled model, however, uses MODFLOW to represent subsurface storage. Groundwater systems are characterized by algorithms different than those used in surface-water models; moreover, they have a variably thick unsaturated zone and vertically and horizontally heterogeneous subsurface storage. As a result, groundwater models typically require longer spin-up periods. Indeed, if a calibration observation integrates multiple years (for example, groundwater conditions in combined unconfined and confined aquifers), it can take a multiple-year spin-up before the dynamics of the system are well represented in the model (Hunt and others, 2009). The characteristics of the basin itself can be important. Basins with high hydraulic diffusivity (that is, high hydraulic conductivity and low storage) move water more quickly than basins with low hydraulic diffusivity; even more important, basins with large distances from the groundwater divide to important sinks drain slower than those with short distances. The goal for coupled model calibration is to have a sufficiently long spin-up such that parameter calibration does not simply reflect poor simulation of initial conditions. Long spin-up periods, however, add proportionally to the total run time of the coupled model. In the BEC area, the Paleozoic bedrock includes laterally extensive confining units that decrease the overall hydraulic diffusivity of the system. The Paleozoic bedrock also has greater than (>) 10 miles of distance from the groundwater divide to the nearest sink in the lowest Mt. Simon aquifer - the confined aquifer containing 80 percent of the basin's transmissivity. These factors result in a longer required spin-up period ( $>10$ years) than systems without confining units (for example, Hunt and others, 2013).

\section{Considerations for Calibrating a Coupled Groundwater/Surface-Water Model}

Surface-water datasets typically involve many measurements over time at a small number of locations. Such timeseries data contain measurement uncertainty and redundant information, especially with respect to the temporal density of the observations (Hunt and others, 2009). Therefore, calibration of the groundwater and surface-water systems included processing of the streamflow data in addition to calibration of the raw observation measurements alone. Groundwater data are more buffered from transience at the surface and typically are not as temporally dense.

Daily data for 1985-2007 and other data collected as part of the project (appendix 5) were used for all transient model calibration and were processed by the time-series processor TSPROC (Westenbroek and others, 2012); averages of measurements for these periods were used for calibration of the uncoupled steady-state groundwater model. The calibration focused primarily on monthly streamflows in the basin, with primary emphasis on the long term streamgage on Black Earth Creek in the Village of Black Earth (USGS station 05406500). 
All hydrologic models were calibrated by using the universal parameter estimation computer code PEST (Doherty, 2014a,b) using guidelines presented by Doherty and Hunt (2010). The PEST optimization algorithm systematically adjusts coupledmodel input parameters in a series of model runs. After each model run, simulated model outputs such as groundwater levels, vertical head gradients, and streamflows were automatically compared to observed equivalents measured in the field. Model runs continued until a best fit between simulated and measured targets was attained. Details on the calibration methodologies of the uncoupled and coupled models are provided in appendix 3 , and results of each calibration exercise are given in appendix 6 . A brief overview of coupled modelcalibration considerations follows.

Coupled simulations have run times that are much longer than if only an uncoupled groundwater or surface-water model is used. In many cases, forward model run times can become limiting for practical calibration. Moreover, many of the coupled-model calibration parameters are primarily associated with one of the two systems and, therefore, are typically informed by an uncoupled simulation. Thus, insight can be gained from an initial calibration of the faster, uncoupled runs available from a transient "PRMS-only" and steadystate "MODFLOW-only" mode of GSFLOW (Markstrom and others, 2008). For the study described herein, this initial separate calibration provided a sufficiently accurate starting point for coupled model calibration; thus, additional parameter estimation using the sequentially linked calibration approach (that is, using an intermediate calibration step that links a transient PRMS-only model to a steady-state MODFLOW model; Hunt and others, 2009, 2013) was not required. Rather, results from the uncoupled PRMS-only and MODFLOW-only models were used directly for the final calibration of the final coupled transient GSFLOW model.

\section{SNTEMP Temperature Model Description, Construction, and Calibration}

A stream-temperature model was developed to use coupled flow model output to simulate daily mean stream temperatures along the main stem and select tributaries to Black Earth Creek. This section briefly describes the model framework, data collection and synthesis, and calibration procedures for the stream-temperature model; appendix 4 provides a more extensive description. Locations of field-measured stream temperature are shown in appendix 4 (fig. 4-1).

The instream-water-temperature model SNTEMP (Stream-Network TEMPerature; Bartholow, 1991) was used to simulate stream temperatures in Black Earth Creek and its tributaries. SNTEMP is a one-dimensional heat-transport model that uses a successive steady-state approach to simulate daily mean and maximum temperatures as a function of distance along the stream and environmental heat flux. A heat-transport equation describes the downstream movement of heat energy in the water and actual exchange of heat energy between the water and its surrounding physical environment (Theurer and others, 1984). Net heat flux is calculated by using inputs describing meteorology, hydrology, stream geometry, and shade setting for a dendritic network of main stem and tributary stream segments that constitute the stream system of interest. The Black Earth Creek stream network was represented by the main stem and six main tributaries: Brewery Creek, Garfoot Creek, an unnamed tributary approximately 0.5 kilometer upstream from Garfoot Creek, Vermont Creek, Marsh Valley Creek, and Halfway Prairie Creek. Each stream was discretized into two or more segments with the exception of Brewery Creek and the unnamed tributary, which were characterized into a single segment due to their relatively homogeneous reach characteristics and linear nature. Physical, meteorological, and hydrological characteristics of each segment - such as width, groundwater accretion rate, and topographic and riparian vegetation conditions-are uniform over the segment. Although each stream segment requires a physical description of stream geometry, hydrology, and shading variables, meteorological variables are considered global in nature and were applied to all stream segments uniformly. In SNTEMP, it is assumed that all input data, including meteorological and hydrological variables, can be represented by 24-hour averages (Bartholow, 1991). Many of the model input parameters were taken from published data sources; groundwater inflow to stream segments were derived from GSFLOW model outputs. Additional field data were also collected to characterize the meteorological, hydrological, and streamtemperature parameters (appendix 4).

A SNTEMP model consists of component modules that have input that can be categorized into three broad categories of stream geometry, meteorology, and hydrology. Streamgeometry data consist of the network layout for the main stem and all tributaries including site elevations, stream widths, Manning's n values, and shade estimates (appendix 4). The width of each stream segment represents an average and was assumed to remain constant for all values of flow. Manning's n values were also assumed to apply to all values of flow; estimates were initially based on reported ranges for natural channels and were adjusted during calibration. Stream-shading parameters, such as vegetation height and density, were initially specified using field-measured values then adjusted during calibration (appendix 4). Meteorological data consist of measured solar radiation, air temperature, relative humidity, wind speed, and cloud cover. SNTEMP uses only one set of meteorological data, which is applied to all stream segments. Air temperature, cloud cover, dust coefficients, and ground reflectivity were taken from existing published values (appendix 4). Default values were used for all other meteorological variables required by SNTEMP.

Hydrologic data consist of stream discharge and water temperatures. SNTEMP requires upstream discharge and temperature data for each modeled stream segment. For SNTEMP 
calibration, daily mean discharge data were based on coupled GSFLOW simulation output or supporting measured discharge data when available. All future scenarios were run with GSFLOW simulated flows for groundwater inputs to streams. Mean groundwater temperatures were based on measured values from monitoring wells located within the watershed. These temperatures remained relatively constant and were consistent with those reported by Novitzki (1973); therefore, mean groundwater temperature was applied equally across each stream segment in the model using GSFLOW-derived inflows. The time period May through September 2005 was selected for model calibration because it spans the longest continuous water temperature and discharge datasets at multiple locations throughout the Black Earth Creek stream network during the GSFLOW model-calibration period. After data processing and formatting for the SNTEMP model, calibration consisted of fitting simulated daily mean stream temperatures to observations in the field. Calibration was achieved by trial-and-error adjustment of SNTEMP input variables until agreement was reached between simulated and measured calibration locations. Manual calibration was required because the SNTEMP code available used an integrated graphical user interface and did not run in stand-alone batch mode.

\section{Climate-Change Scenario Construction}

Multiple General Circulation Models (GCMs) were used to obtain a range of potential future climatic conditions. Thirteen GCMs (table 1) from the Intergovernmental Panel on Climate Change (IPCC) Fourth Assessment Special Report on Emission Scenarios (Intergovernmental Panel on Climate Change, 2007) were chosen primarily due to their output of daily precipitation and temperature output/input required for the GSFLOW model simulations. For each GCM, one current and three future scenarios were used (table 1). The GCM output was downscaled for the BEC area by the Wisconsin Initiative on Climate Change Impacts (WICCI) (2011), which is a recent downscaled dataset. Downscaled GCM results were available as daily precipitation and minimum and maximum temperatures for three time periods: 1961-2000, 2045-65, and 2081-2100. The GCM potential future climate conditions were obtained for the 19 temperature and 26 precipitation station locations used in the model calibration and then interpolated to individual HRUs using the ide_dist algorithm in PRMS (appendix 2).

Three potential hydrologic issues of concern were targeted: (1) changes to streamflow and stream temperature, (2) changes in groundwater-surface water interaction, and (3) changes in soil moisture. Thus, climate scenario results focused on these three issues. Initial conditions used for assessing hydrologic changes were derived from the GSFLOW model calibrated to heads and flows collected during 1993-2007. For the WICCI climate scenarios, the first 20 years of the 1961-2100 simulation period were discarded to ensure that sufficient spin-up time was used to obtain a representation of dynamic equilibrium in the groundwater/ surface-water systems. The period of 1995-2000 was used in the WICCI scenarios as a baseline for subsequently assessing hydrologic change.

The BEC groundwater system has a relatively long hydrologic response time due to low hydraulic diffusivities in some of the Paleozoic bedrock units. This delayed response became apparent when evaluating the individual WICCI scenario periods. The 20-year lengths of the WICCI periods were insufficient for the model to reach a state of dynamic equilibrium. Similarly, repeated simulation of the early 15 -year spinup of each period for initial conditions produced results that were inconsistent between the periods. Model results from the WICCI climate scenarios (figs. 23, 25, and 26) indicate that some aspects of the BEC system, in particular groundwater heads and base-flow-dominated streams, never reach a steadystate condition but rather had consistent trends in the output throughout the 140-year run period.

Reasonable initial conditions for the WICCI periods were approximated by filling in the gaps between WICCI periods with synthetic temperature and precipitation data, so that the model could be run continuously from 1961 to 2100 . The following procedure was used to generate synthetic data for the two gaps (2000-45 and 2065-80):

At each climate station, average annual mean temperatures and precipitation were computed for the entire periods before and after each gap.

1. Linear interpolation was then used to apply the change in annual means at each climate station incrementally to each year between the periods.

2. Daily differences from the average annual mean value were computed for a length of time equal to one-half of the gap, for a period ending at the beginning of the gap, and for a period beginning at the end of the gap. These were combined sequentially, resulting in time series of daily differences for each station of equal length to the gap.

3. The time series of daily differences were then added to the interpolated annual means developed in step 2 .

This procedure resulted in climate time series that represented the broad trends between the periods and had realistic variability and correlation between individual daily values. To minimize any artifacts from the synthetic climate data, only the last 5 years of the 2045-65 and 2081-2100 periods were used for illustration of climate change effects on the BEC system.

The climate forcings for the 13 GCMs and the three emissions scenarios are depicted in figure 7 , where solid lines represent the annual average across the 13 GCMs for each emission scenario and shaded areas represent the annual maximum and minimum across the 13 GCMs for the three emissions scenarios. In general, all of the models show a substantial increase in maximum temperature (fig. $7 \mathrm{~A}$ ) and minimum temperature (fig. 7B), with a consistent, larger increase in 
minimum temperature compared to maximum temperature. The B1 scenario (table 1) tends to have the smallest increase in temperature; the A1B and A2 scenarios had higher projected temperatures. The variability in temperatures shows a somewhat gradual increase over time, which represents increased uncertainty the further the prediction is in the future. To update groundwater temperatures for climate-scenario simulations, a constant offset of $-2.2^{\circ} \mathrm{C}$ was applied to simulated average annual air temperatures. The offset was based on the difference between the 30-year normal air temperature (1971-2000) and observed groundwater temperatures during the calibration period (May-September 2005) and similarly reported by Novitzki (1973). This offset was then used to calculate future groundwater temperatures from potential future air-temperature increases provided by the GCMs/emission scenarios; all other temperature model parameters retained the calibrated values. The predicted climate trends for precipitation are more ambiguous than those for temperature, with more than plus or minus $( \pm) 10$ percent variability surrounding current precipitation rates throughout the scenario time period and slightly greater uncertainty towards the end of the scenario period.

Climate-change effects on air temperatures are expected to affect timing and length of growing season (Christiansen and others, 2011). The growing season affects the onset of evapotranspiration in the spring and plant senescence in the fall-dates required for simulation of potential changes to hydrologic flows. Similar to the calibration period calculation of growing season, the beginning and end dates of the growing season for the climate-change scenarios were preprocessed for each simulation year by using an algorithm described in Christiansen and others (2011) and documented in Markstrom and others (2012, 2015). An assumed killing-frost temperature of $-2.2^{\circ} \mathrm{C}\left(28^{\circ} \mathrm{F}\right)$ was used for each HRU. During calibration, the growing season was determined as average values for the calibration period. In the climate-change scenarios, the growing season was determined for each year in the simulation period by using minimum temperature input for each specific

Table 1. A, Selected General Circulation Models (GCMs) used to simulate future climate conditions.

\begin{tabular}{|c|c|c|}
\hline Model abbreviation & Model identifier & Organization \\
\hline $\begin{array}{l}\text { cccma_cgcm3_1 } \\
\text { ccma_cgcm3_1_t63 }\end{array}$ & CGCM3.1(T47), 2005 & Canadian Centre for Climate Modeling and Analysis, Canada. \\
\hline cnrm_cm3 & CNRM-CM3, 2004 & Centre National de Recherches Météorologiques, France. \\
\hline csiro_mk3_0 & CSIRO-MK3.0, 2001 & $\begin{array}{l}\text { Commonwealth Scientific and Industrial Research Organization (CSIRO) Atmospheric } \\
\text { Research, Australia. }\end{array}$ \\
\hline gfdl_cm2_0 & GFDL-CM2.0, 2005 & $\begin{array}{l}\text { National Oceanic and Atmospheric Administration (NOAA) Geophysical Fluid } \\
\text { Dynamics Laboratory (GFDL). }\end{array}$ \\
\hline giss_aom & & \\
\hline $\begin{array}{l}\text { giss_model_e_r } \\
\text { iap_fgoals1_0_g }\end{array}$ & & \\
\hline $\begin{array}{l}\text { miub_echo_g } \\
\text { mpi_echam5 }\end{array}$ & & \\
\hline mri_cgcm2_3_2a & MRI-CGCM2.3.3, 2003 & Meteorological Research Institute, Japan. \\
\hline
\end{tabular}

Table 1. $B$, Selected emission scenarios used to simulate future climate conditions.

\begin{tabular}{cc}
\hline Scenario & Description \\
\hline A1B & $\begin{array}{c}\text { Rapid economic growth, global population peaking in mid-century and declining thereafter, and introduction of new and } \\
\text { efficient technologies with a balance across all sources. } \\
\text { A2 }\end{array}$ \\
$\begin{array}{c}\text { Very heterogeneous world with self-reliance and preservation of local identities with gradual population growth and slow } \\
\text { regional economic growth and technological change. } \\
\text { B1 }\end{array}$ & $\begin{array}{c}\text { Convergent world with population change as described in the A1 scenarios with rapid changes towards a service and } \\
\text { information economy with clean and resource-efficient technologies. }\end{array}$ \\
\hline
\end{tabular}



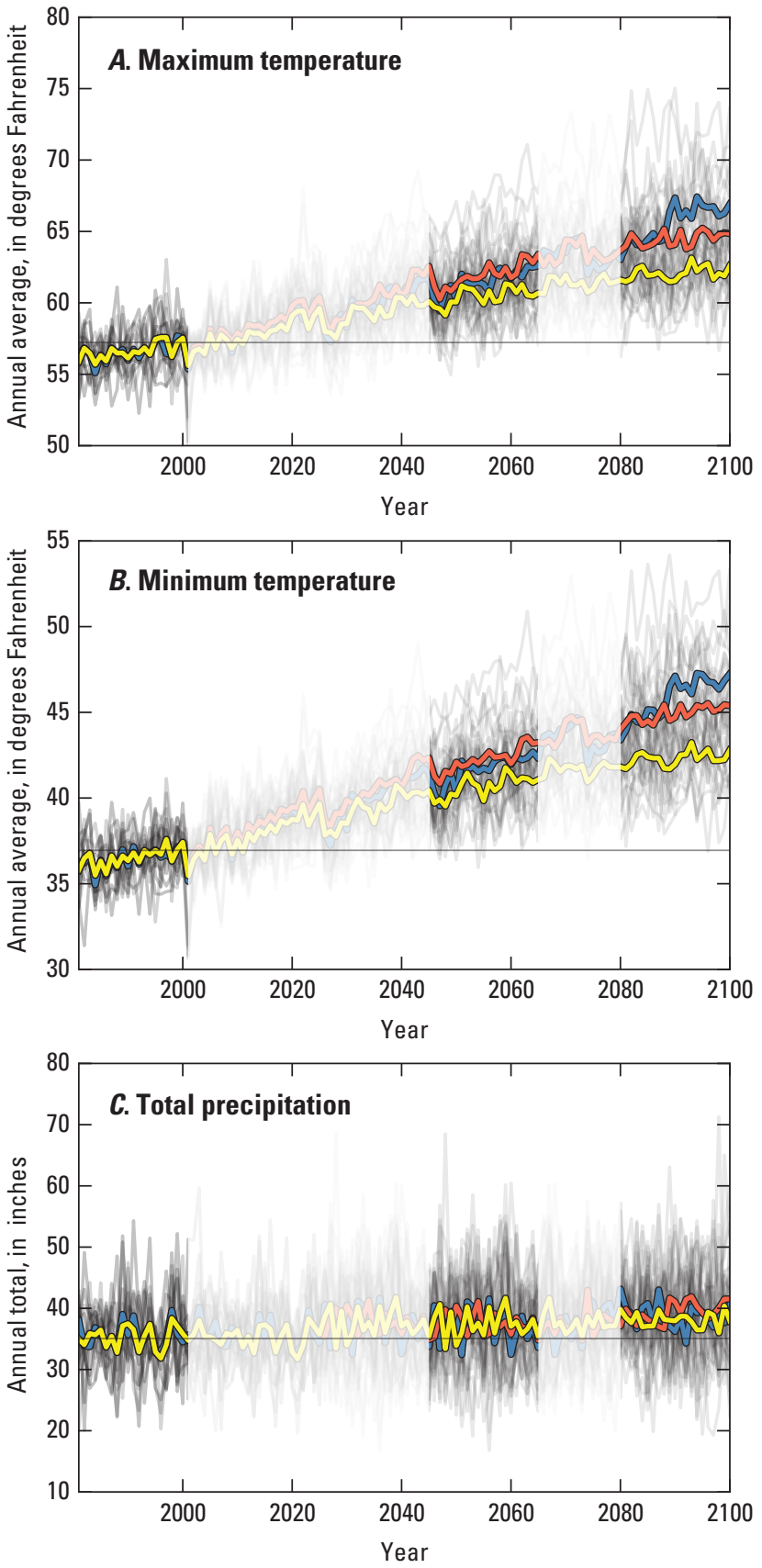

EXPLANATION

sresa1b

sresa2

sresb1

Figure 7. Climate forcings from the Wisconsin Initiative on Climate Change Impacts (WICCI) downscaled data for six General Circulation Models (GCMs). The range of results for $\mathrm{A} 1 \mathrm{~B}$ and $\mathrm{B} 1$ emission scenarios represents all $13 \mathrm{GCMs}$; the range of the $\mathrm{A} 2$ emission scenario is from $9 \mathrm{GCMs}$. $A$, Maximum temperature. $B$, Minimum temperature. $C$, Total precipitation. The left-hand plot shows the uncertainty expressed by the GCMderived climate drivers; the right-hand side shows a boxplot that distills the averages from the two future periods and compares them to current conditions.
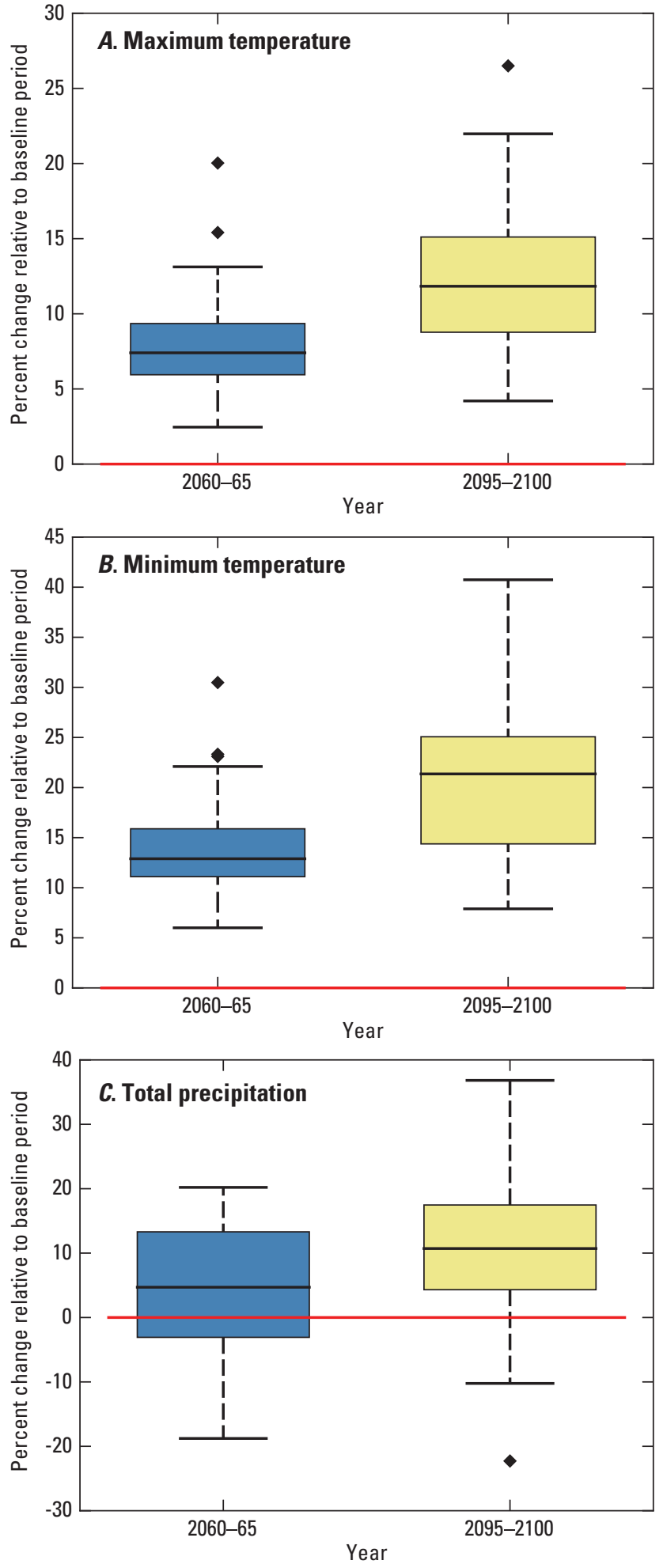

EXPLANATION

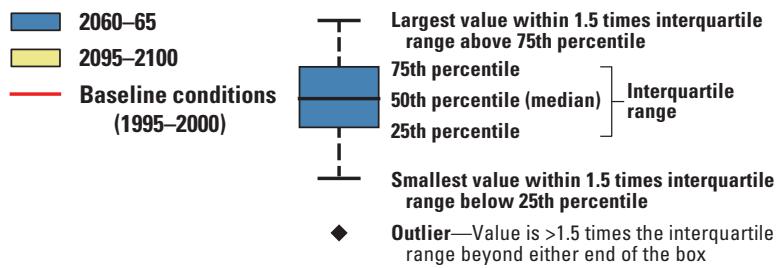


GCM and emissions scenario. A preprocessing program was used to write a file of transpiration flags for each day for each HRU, indicating whether transpiration is on (flag $=1$, which specifies a day within the growing season) or off (flag $=0$ ). The GSFLOW model read the transpiration flags directly from the preprocessed file using the climate_hru module. Current cropping and land use were assumed for each future growing season calculated.

The effect of the climate-change scenarios on stream temperature was assessed by inputting GCM-derived changes to air temperature and associated GSFLOW-simulated streamflows into the calibrated SNTEMP models for each stream. Each of the six GCM and three emission scenarios provided average daily air temperature and solar radiation data necessary to compute an average daily stream temperature at the farthest downstream segment of the model domain. All other temperature-model parameters retained the calibrated values.

\section{Results and Discussion}

Detailed description, graphics, and tables of calibration results for each uncoupled model and the coupled model are described separately in appendix 6; calibration results are briefly highlighted here. It should be noted that this section uses a watershed perspective, where simulated results of the model are reported as a watershed total flux or volume. Although useful for describing the response of the larger system, smaller areas within the watershed can have local conditions different from that reported here using the larger-scale presentation.

\section{GSFLOW Coupled Hydrologic Flow Model}

Simulated precipitation distributed across the BEC watershed was representative of annual precipitation measured around the basin (fig. 8); precipitation is considered simulated because rain gages typically have bias. The model allows the measured rain gage data to be modified within user supplied limits. Simulated precipitation was higher than measured precipitations, which reflects bias within the precipitation gages themselves as well as the measured data undersampling areas of high elevation in the watershed that tend to have higher precipitation. As a result, there seems to be a slight but systematic reduction in precipitation measured in low-lying areas, both in the eastern (Middleton, fig. 8) and western (Mazomanie, fig. 8) portions of the model domain; simulated precipitation is more similar to the higher elevation areas of the basin (for example, Mt. Horeb, fig. 8).

Overall fit to measured streamflow was adequate (appendix 6, figs. 6-14 through 6-19). Fits were better at locations with longer high-quality records, reflecting the increased weighting of these locations in the calibration. The most downstream location of a watershed is important for obtaining a representative simulator (Hunt and others, 2005); the streamflow record from the BEC watershed outlet at Mazomanie was also well simulated, although it should be noted the period of record is shorter than other locations. Timing and magnitude of snowpack were also adequately simulated in the coupled GSFLOW model (appendix 6); streamflows during snowmelt-period peaks, however, were simulated less well than streamflow at other times of the year because (1) calibration focused on streamflows from all months of the year and thus did not emphasize snowmelt periods, (2) a poorer fit during snowmelt is expected because long-term snow depth measurements are only available in the adjoining Yahara River watershed (Truax Field, Madison, Wisconsin), and (3) the lack of representative frozen-ground processes limits the coupled GSFLOW model's ability to simulate high snowmelt discharges.

Atmosphere-earth processes solar radiation and associated potential evapotranspiration (ET) processes were well simulated by the model (appendix 6, figs. $6-1 \mathrm{~A}$ and $6-1 \mathrm{~B}$, respectively). Evapotranspiration is a dominant process that moves precipitation that falls on the watershed back to the atmosphere by way of evaporation and plant transpiration; therefore, ET can be thought of as reflecting water that is not available for streamflow generation and groundwater recharge. Evapotranspiration is divided into (1) "potential ET," which reflects the maximum ET rate that would occur if there was no limitation of water; and (2) "actual ET," which reflects only the ET that can occur given water available for evaporation and transpiration. For watershed water budget calculations such as streamflow and groundwater flow, actual evapotranspiration is the ET form that is of most importance. For the 2000-7 period, simulated actual evapotranspiration removed 53 to 76 percent of the annual precipitation that fell into the watershed. Years with more precipitation (for example, 2000 and 2007, figs. 9A and 9B) had more actual ET. However, the difference between precipitation and actual ET is most pronounced during wet years, which suggests that precipitation is moving off the landscape by way of surface runoff and infiltration out of the soil zone faster than ET can intercept it during wet years. During dry years (for example, 2002 and 2005 in figs. $9 A$ and $9 B$ ), runoff is reduced and precipitation and ET rates are more closely matched.

The calibrated model closely simulated most of the observed data used for groundwater calibration, including average heads, timing of head dynamics, and average base flow (appendix 6). The transient calibration focused on the temporal dynamics of the head time series; thus, calibration emphasized temporal head differences rather than matching the absolute head values measured over time themselves. For the head data available for calibration, the simulation generally represents the timing and magnitude of the observed groundwater system over the majority of the observed head dataset and the mean head.

The notable exception to the fit is observed heads from the Mt. Simon deep well located east of the Village of Cross Plains (fig. 10). This well is screened in the confined Mt. Simon aquifer, which shows a $>25$-foot head gradient 


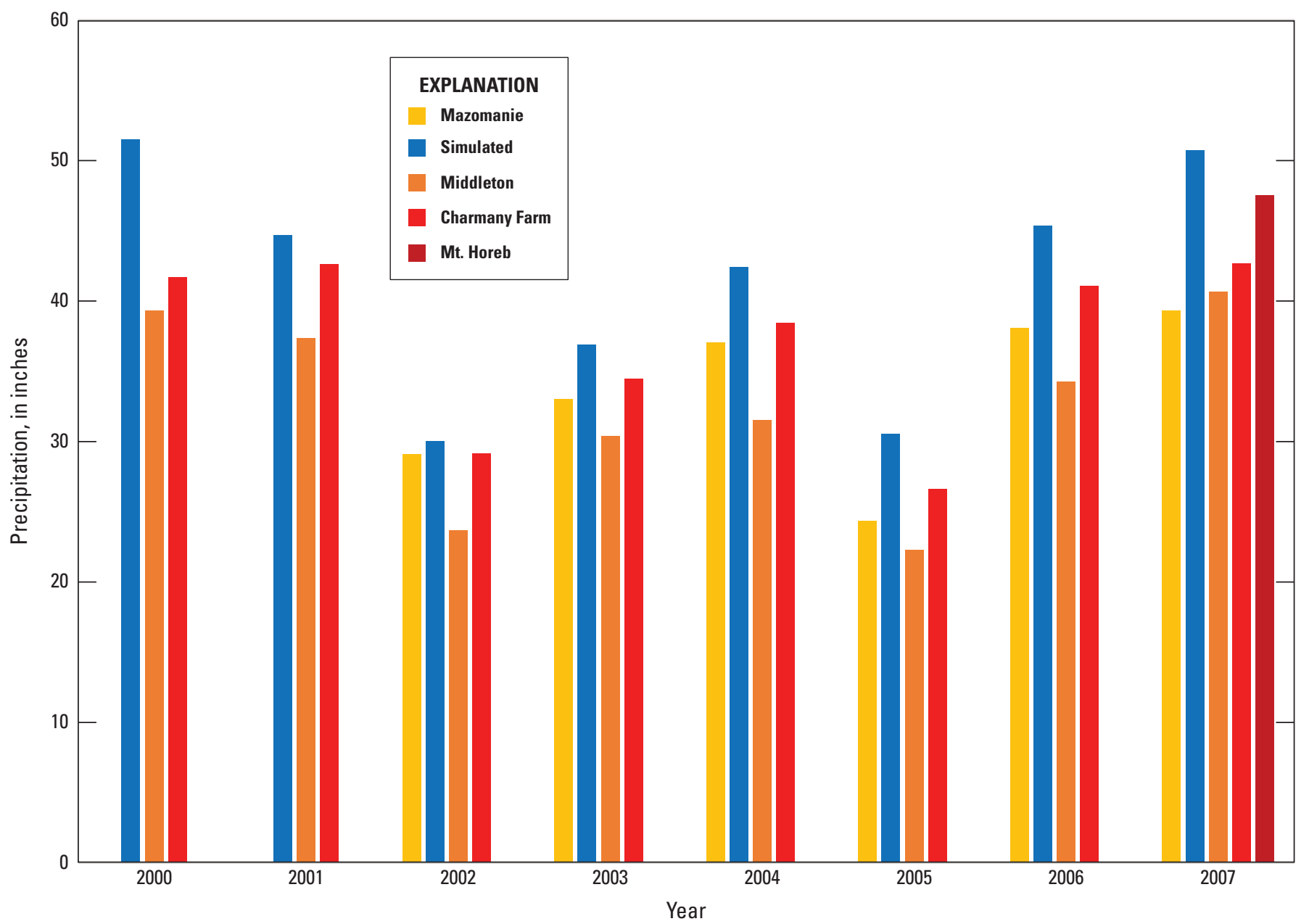

Figure 8. Annual precipitation measured around the Black Earth Creek watershed during the 2000-7 calibration period compared to the average precipitation used for the simulation.

between it and the shallow groundwater system. This lack of fit results from an inefficient transmission of water between the shallow and deep aquifers; however, the temporal dynamics of head variation in the deeper cased well has dynamics that mimic the shallow system (fig. 10), which indicates that the forcing functions are similar for the two aquifers. The poor representation of Mt. Simon well head is likely a result of the confined aquifer being simulated by using static perimeter boundary conditions, which are conditions that do not represent the temporal dynamics of the regional groundwater system that is observed in the deep aquifer head measurements; that is, even though the distance to the perimeter boundaries of the lowermost Mt. Simon aquifer are large, the high hydraulic diffusivity of the confined aquifer facilitates relatively rapid transmission of changes to pressure in the groundwater system, such as observed at the Mt. Simon well, even if large volumes of water are not transmitted. However, the modeling purpose focused on the interaction between the shallow groundwater system and the Black Earth Creek surface-water system; thus, representative simulation of mean head without temporal dynamics resulting from simplifications to boundaries of the deep confined aquifer was deemed acceptable.

Estimated aquifer hydraulic conductivities and anisotropy ratios (table 2) are similar to those obtained from previous modeling (Krohelski and others, 2000) and data compilation (Bradbury and others, 1999). The glacio-fluvial sediments in the stream valleys had high $\mathrm{K}_{\mathrm{h}}$ (ranging from 213 to 897 feet per day), with highest values simulated near the western edge of the glaciated area, which is consistent with glacio-fluvial sediments deposited near the ice margin of the terminal moraine. The fluvial sediments in the unglaciated river valleys had lower hydraulic conductivity than the glacio-fluvial sediments but were higher than the other glacial units and bedrock aquifers (table 2). The upper Paleozoic bedrock units (above the Eau Claire shale) had appreciably lower $\mathrm{K}_{\mathrm{h}}$. The Tunnel City formation had appreciably higher values of $\mathrm{K}_{\mathrm{h}}$ in the glaciated portions of the model domain and lower in the unglaciated portions. This result indicates glaciated areas were characterized by preferential flowpaths that presumably developed as the high hydrostatic pressure expected from the 

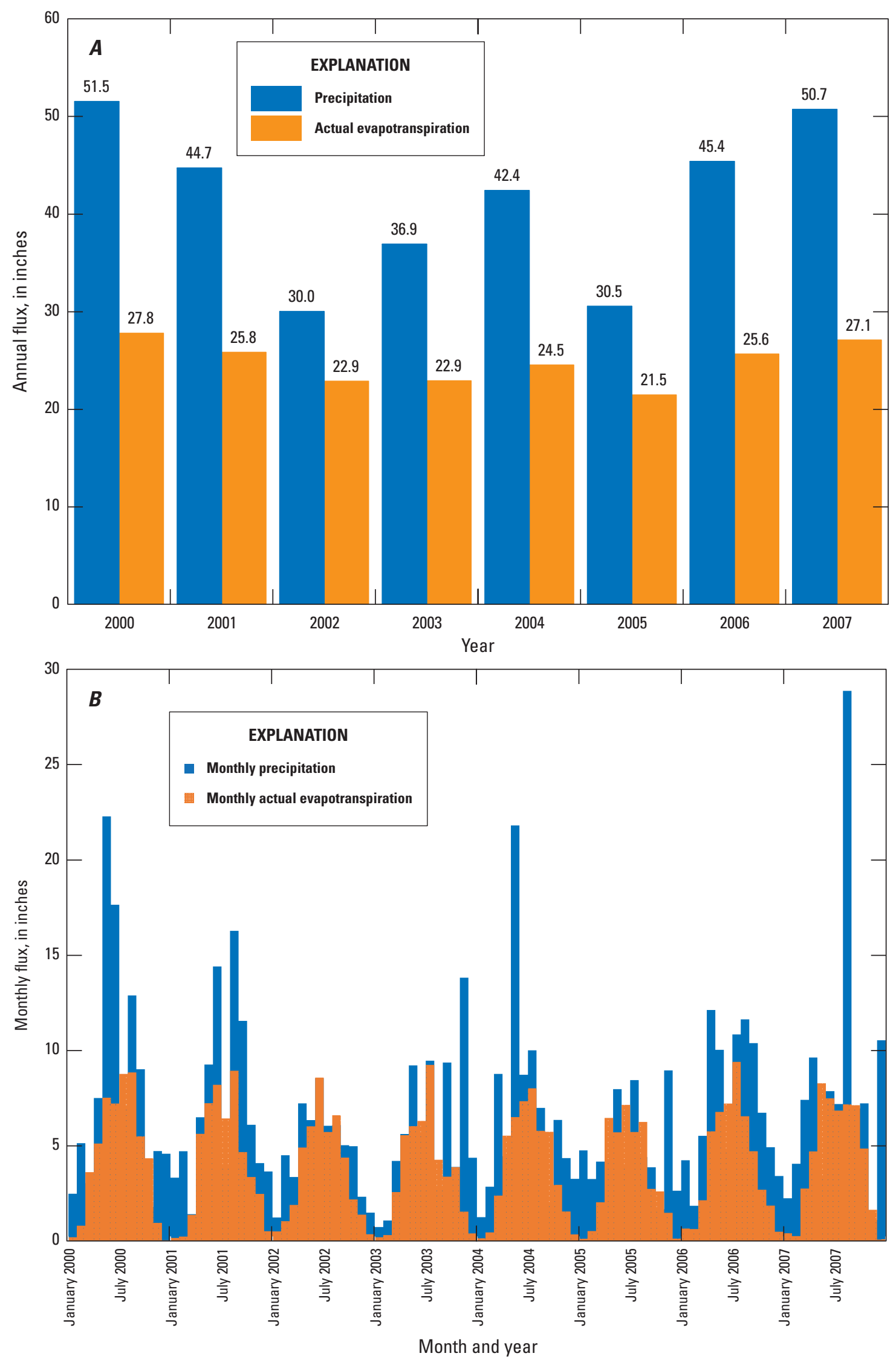

Figure 9. $A$, Annual, and $B$, monthly, simulated precipitation and actual evapotranspiration over the Black Earth Creek watershed, 2000-7. 

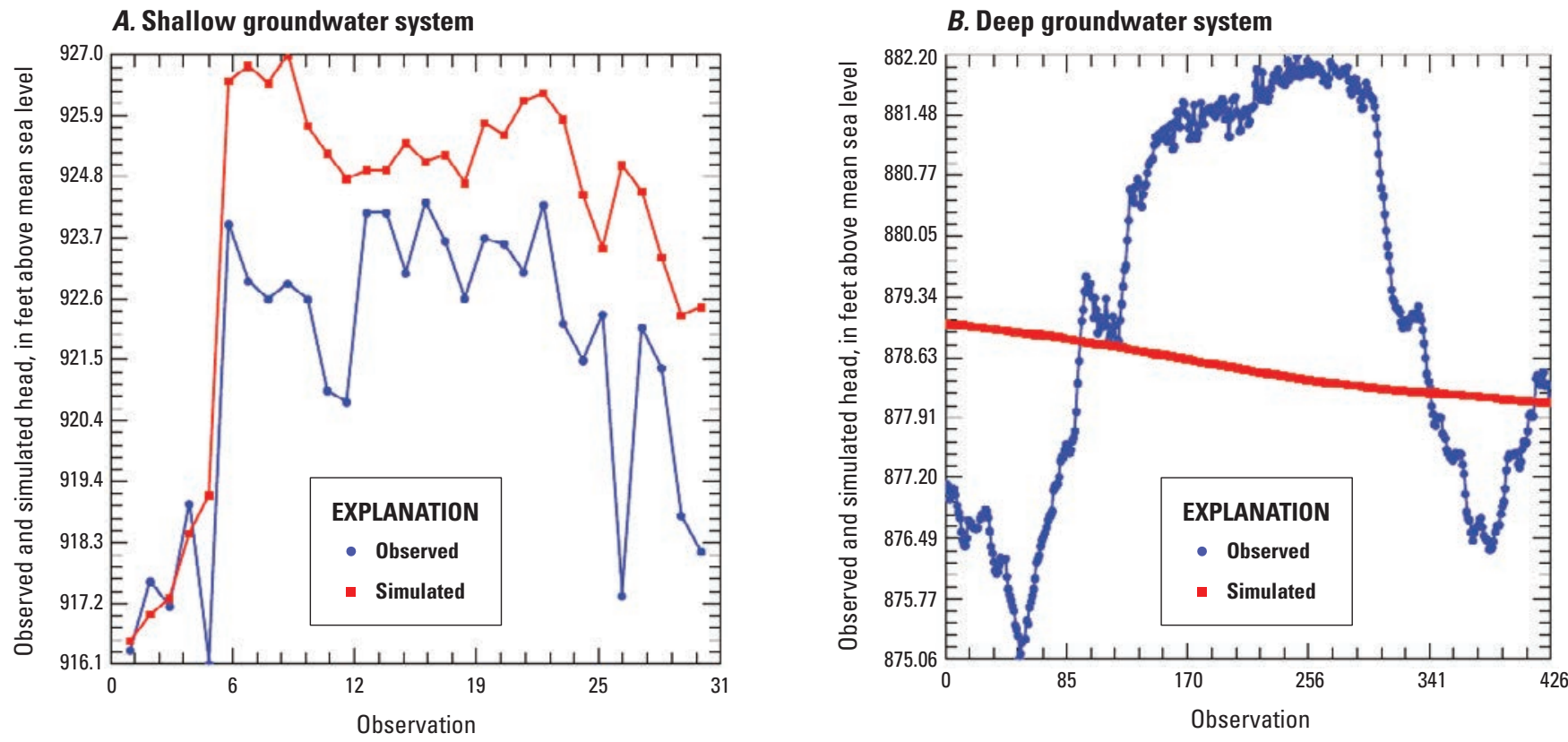

Figure 10. Observed and simulated heads for the $A$, shallow aquifer and $B$, deep confined aquifer east of the Village of Cross Plains.

added weight of the glacial ice exploited weaknesses in the bedrock to discharge water to regional discharge points (for example, pre-glacial Black Earth Creek and Wisconsin River valleys). The lowermost Paleozoic bedrock consists of the Mt. Simon aquifer, which represents most of the transmissivity in the watershed due to its $\mathrm{K}_{\mathrm{h}}$ value and appreciable thickness. It should be noted that the low calibrated $\mathrm{K}_{\mathrm{v}}$ reported for the Mt. Simon aquifer in table 2 is likely representing a bulk average property of the Mt. Simon and overlying Eau Claire shale combined; that is, the Mt. Simon aquifer was simulated using one model layer. This model design results in calibration targets constraining the combined $\mathrm{K}_{\mathrm{v}}$ of the Mt. Simon and Eau Claire shale; the targets used are not able to distinguish the two $\mathrm{K}_{\mathrm{v}}$ values individually. Aquifer storage parameters (table 2) are within the range typical for aquifers.

Average areal recharge over the model domain from the calibrated model for the 2000-7 period is 9.1 inches per year (23.1 centimeters per year) and ranges from 6.9 to 10.8 inches per year (table 3 ). The average recharge rate reported here is consistent with that calculated by using base-flow separation of streamgage data (Gebert and others, 2011); the range of annual recharge rates is similar to those reported by Parsen and others (2016) for the same area. Recharge occurs continually during the year (dark blue line, fig. 11) and is much less temporally variable than precipitation that falls on the land surface or even the water leaving the root zone (medium blue line, fig. 11). The buffering of short-term climate variability is one important function of the unsaturated zone, which in turn facilitates the ability of groundwater systems to supply water during dry periods.
The coupled model output allows for detailed characterization of the groundwater and surface-water systems. Output for the model spin-up period is not included in the analysis and the discussion focuses on later times of the calibration period (2000-7). For example, the holistic simulation of the water budget allows the distribution of land-surface and soilzone flows to be visualized. The coupled model can report the distribution of overland flow between Hortonian flow (resulting from precipitation rates greater than the soil infiltration capacity; Horton, 1933) and saturation excess, also known as Dunnian flow, generated by lack of subsurface storage in lowlying areas (Dunne and Black, 1970), as well as groundwater seepage (fig. 12A); see Hunt and others (2008) for a detailed description of these sources of streamflow. This distribution indicates that overland flow in the uplands (primarily Hortonian flow) is a more common occurrence and can be associated with snowmelt events (fig. 12A); however, some years are without an appreciable snowmelt event (for example, 2005), and extreme summer rains can generate appreciable overland flow (for example, August 2000 and August 2007). Water infiltrated out of the soil zone flow that becomes recharge to the groundwater system (blue line, fig. 12B) is more variable than flow out of the groundwater system by way of seepage (red line, fig. 12B), underscoring the buffering of transience that results from the unsaturated zone. Averaged over the watershed, infiltration out of the root zone is of a similar order of magnitude to the overland flow component - a different result than reported for a northern Wisconsin watershed dominated by transmissive soils, where infiltration is at least one order of magnitude higher than overland flow (fig. 6 in Hunt and others, 2013). 


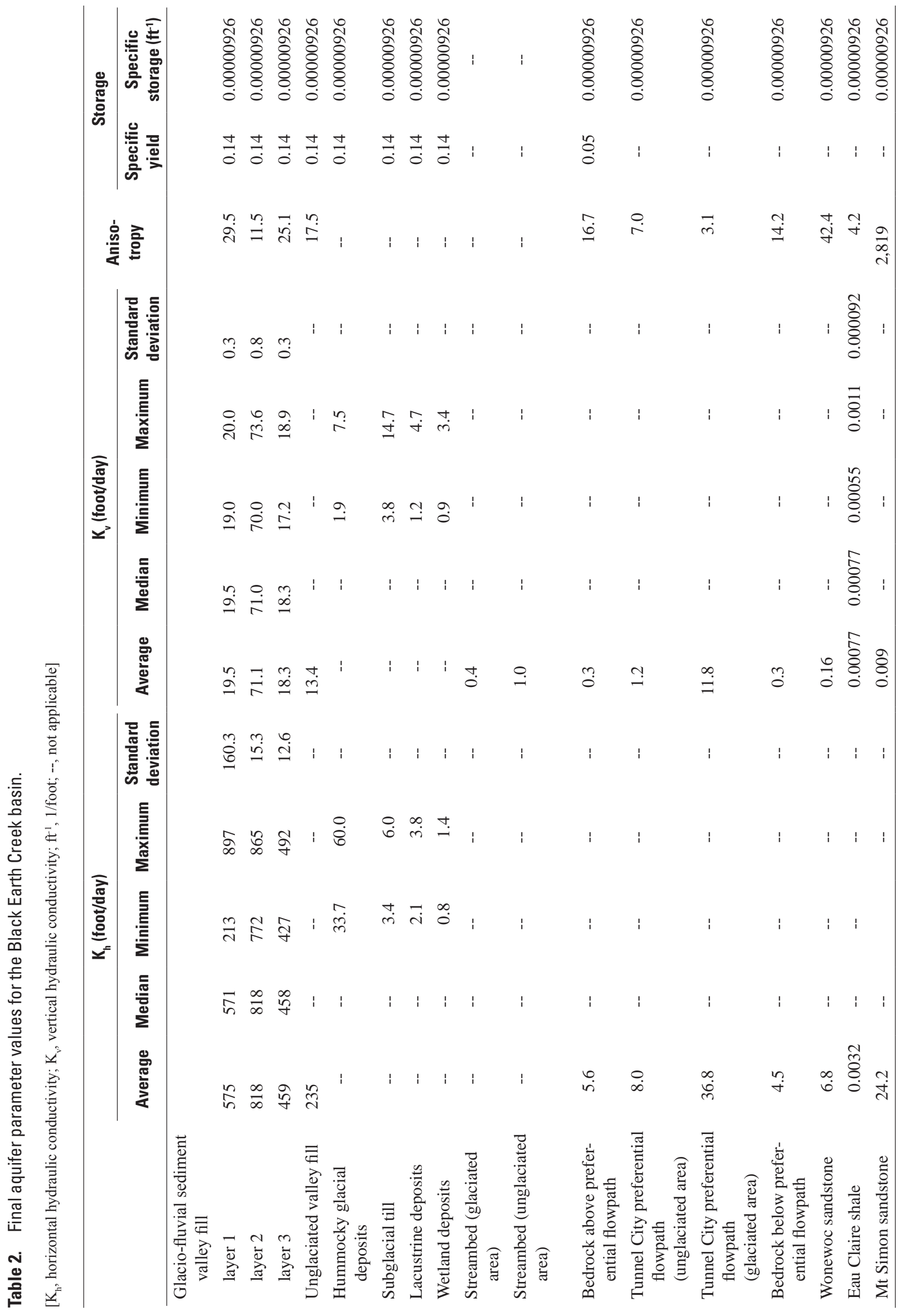


Table 3. Average areal precipitation and recharge rate for the Black Earth Creek model domain reported by the calibrated GSFLOW model.

[in/yr, inch per year; $\mathrm{cm} / \mathrm{yr}$, centimeter per year]

\begin{tabular}{ccccc}
\hline Year & $\begin{array}{c}\text { Precipitation } \\
\text { (in/yr) }\end{array}$ & $\begin{array}{c}\text { Recharge rate } \\
\text { (in/yr) }\end{array}$ & $\begin{array}{c}\text { Precipitation } \\
\text { (cm/yr) }\end{array}$ & $\begin{array}{c}\text { Recharge rate } \\
\text { (cm/yr) }\end{array}$ \\
\hline 2000 & 51.5 & 9.9 & 130.9 & 25.1 \\
2001 & 44.7 & 10.8 & 113.6 & 27.4 \\
2002 & 30.0 & 8.1 & 76.2 & 20.5 \\
2003 & 36.9 & 6.9 & 93.8 & 17.6 \\
2004 & 42.4 & 9.9 & 107.7 & 25.1 \\
2005 & 30.5 & 7.2 & 77.6 & 18.4 \\
2006 & 45.4 & 9.4 & 115.3 & 24.0 \\
2007 & 50.7 & 10.6 & 128.8 & 27.0 \\
$2000-7$ average & 41.5 & 9.1 & 105.5 & 23.1 \\
\hline
\end{tabular}

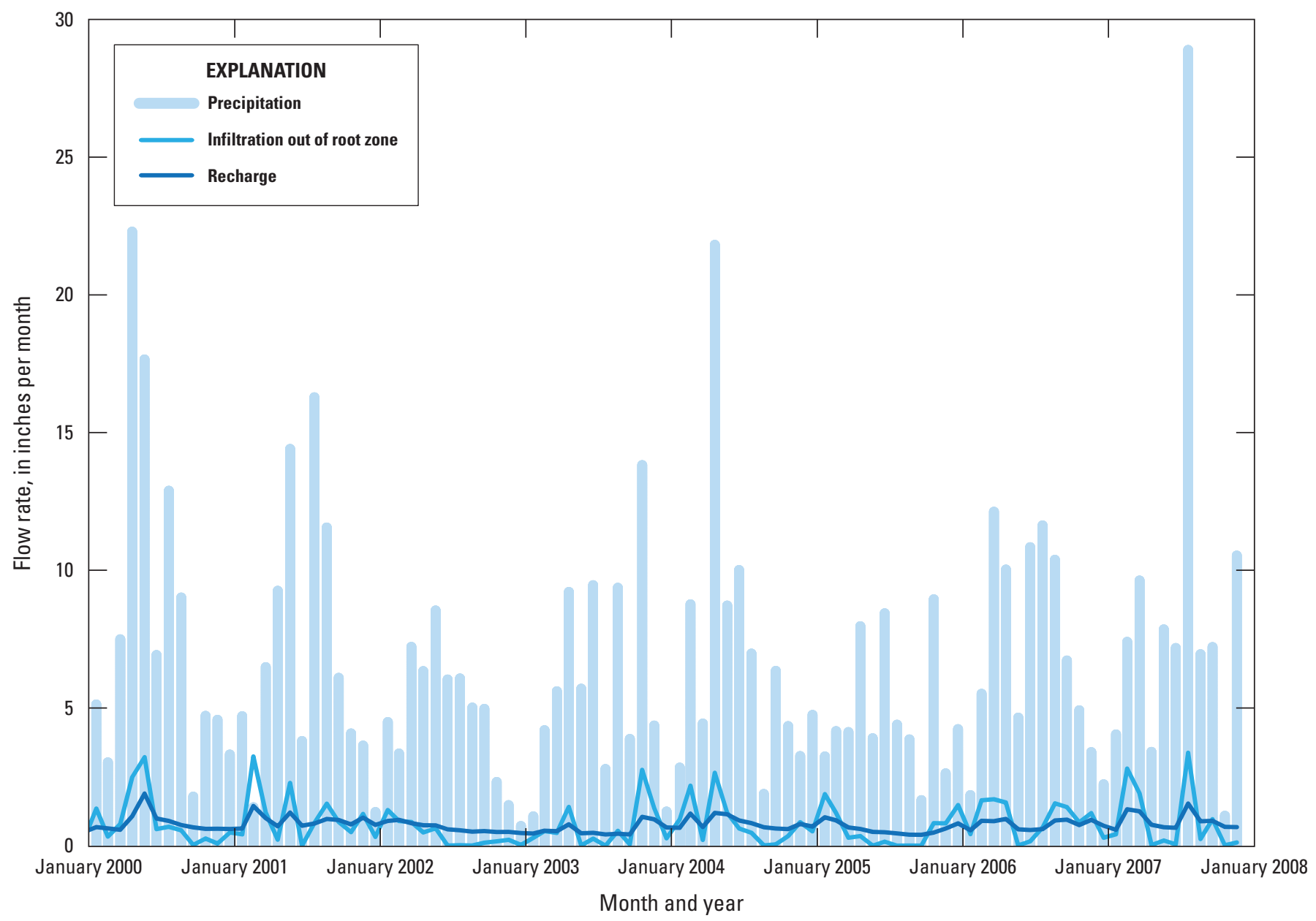

Figure 11. Simulated monthly precipitation, infiltration, and recharge over the Black Earth Creek watershed during the calibration period. Recharge at the water table is steadier than the upper flows, which shows the ability of the unsaturated zone to buffer climatic transience. 

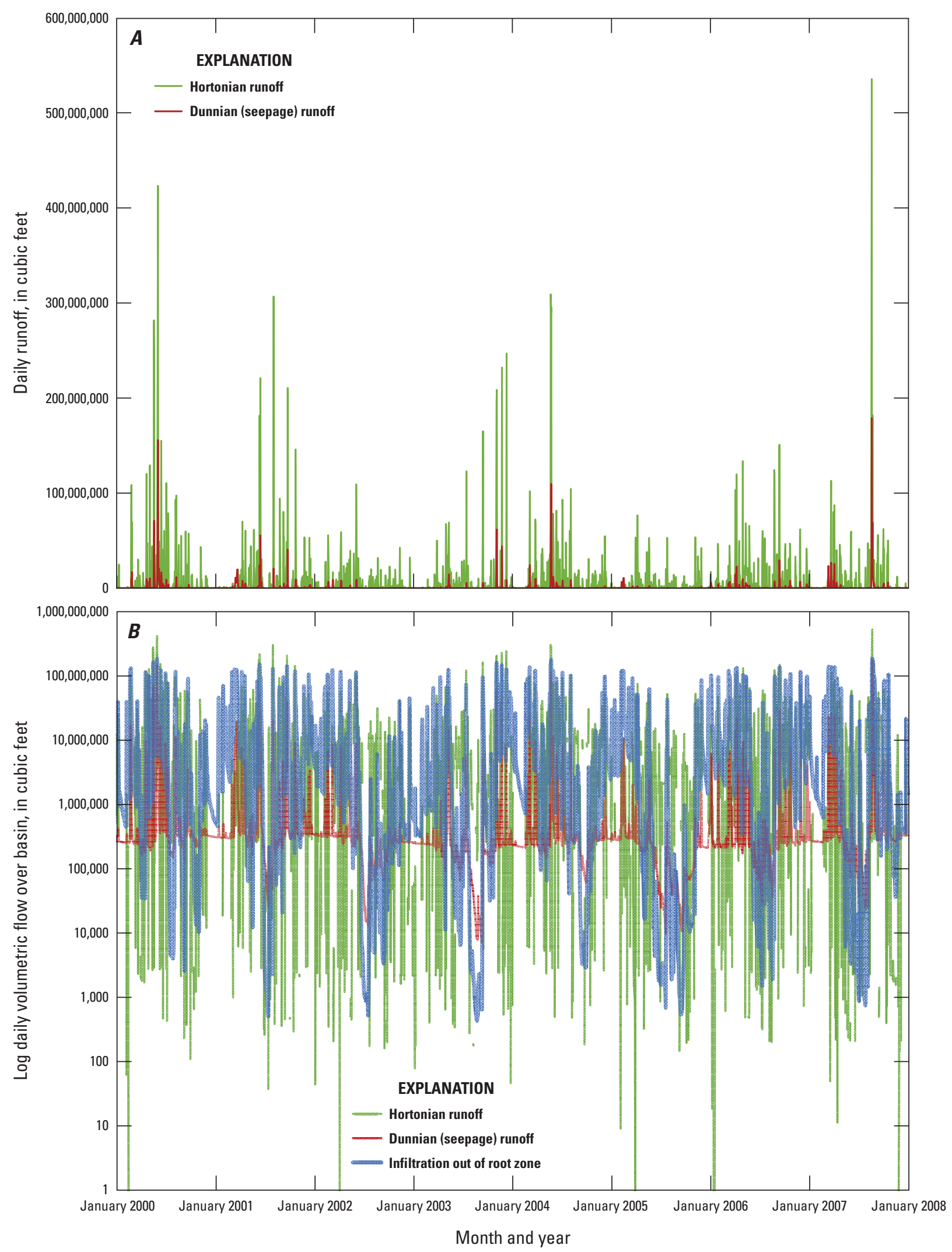

Figure 12. A, Simulated daily flows and $B$, log daily flows for the Black Earth Creek watershed (2000-7). 
Simulation of water budget components for this period illustrates the interaction of factors that influence the water budget in the watershed. First, the dampening of the inherent temporal variability in climate facilitates resilience to shortterm climate variability. The groundwater system especially can provide a steady source of water to the streams even as other sources fluctuate (for example, red line as compared to the green and blue lines in fig. 12). Taken during a longer period, the buffering can impart an appreciable lag between the change in climate and its reflection in the watershed. For example, the groundwater system is connected to the unsaturated zone (the layer below the soil zone but above the water table), and changes to precipitation at land surface are in turn buffered by storage available in the unsaturated zone. Years of high precipitation (2000-1, fig. 9A) result in an increase in water stored in the unsaturated zone (2000-1, green bars, fig. 13). An appreciable decrease in precipitation at the surface in 2002 results in a net loss of water from the unsaturated zone in 2002 but a more muted effect on groundwater recharge rates (fig. 11); however, when precipitation subsequently increases, water flows to fulfill deficits in the unsaturated zone before it can become groundwater recharge. This replenishment of unsaturated zone storage is seen in 2003, with reduction in groundwater recharge (fig. 13) also occurring even though conditions at the surface would be relatively wet. A tipping point is reached when dry years occur close together (2002 and 2003, fig. 9A), during which the water stored in the unsaturated zone is exhausted and drier conditions at the surface are reflected in groundwater recharge in the same year (for example, 2003, fig. 13), whereas the reduction in recharge was lagged 1 year (2002, fig. 13) when the dry year follows wet years. Similarly, a series of wet years together (for example, 2000-1, 2006, and 2007, fig. 9A) can result in climatic conditions again being expressed within the same

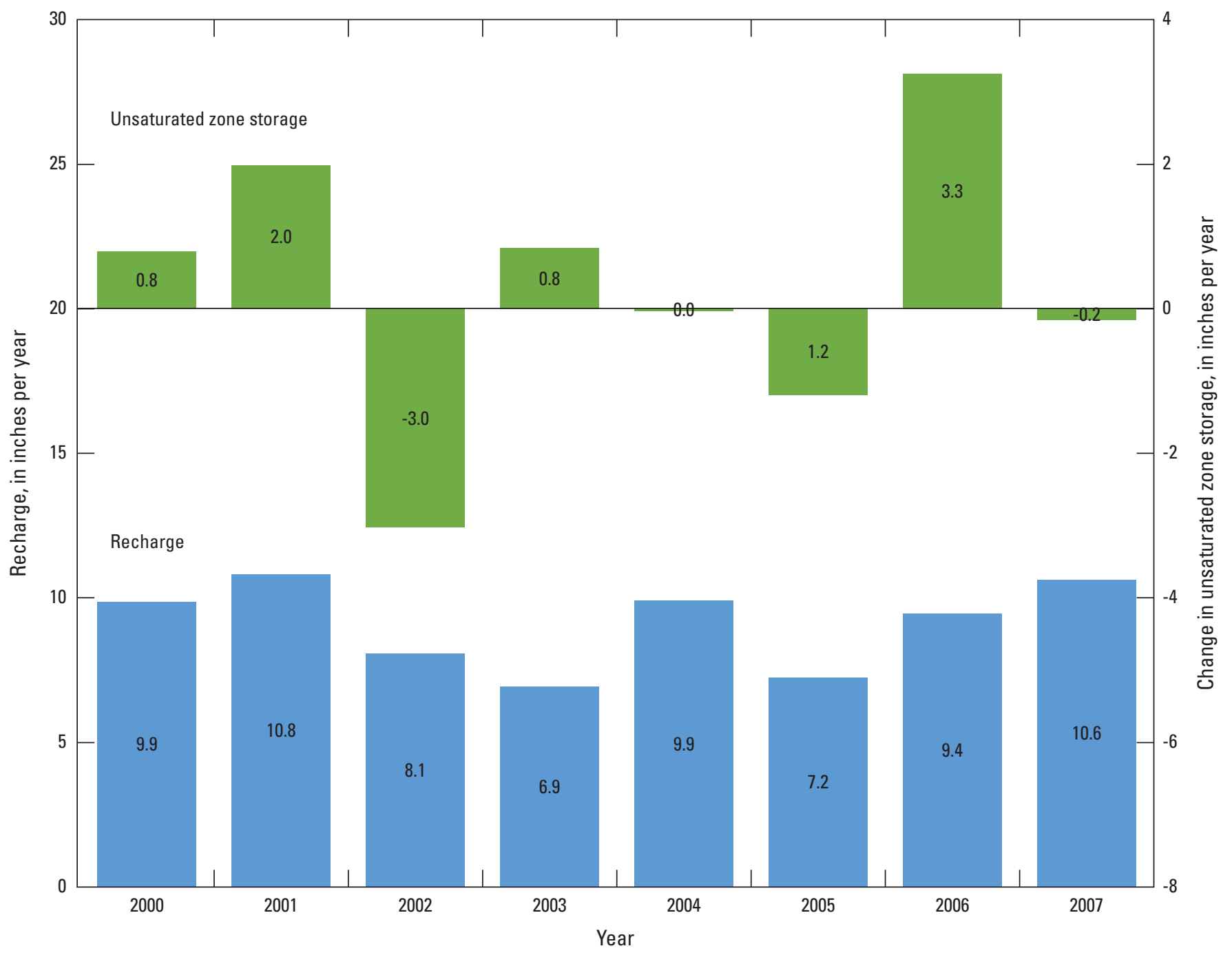

Figure 13. Watershed-wide simulated changes in water stored in the unsaturated zone and rate of groundwater recharge reported as inches over the watershed area. 
year without lagging (that is, high recharge occurs in the same year as high precipitation; for example, 2001, 2006, and 2007 in fig. 13). These interactions and mitigating effects that give different system responses to short- and long-term climate variability underscore the power of a coupled simulation of the surface-water and groundwater systems. An uncoupled modeling approach could not capture, or constrain, the complex interplay of atmospheric drivers, unsaturated zone buffering, and lagged groundwater-system mitigation watershed flows.

\section{SNTEMP Stream-Temperature Model}

Relatively close agreement was obtained between simulated and observed daily mean stream temperature at 15 calibration points along the main stem (9 points) and tributary confluences (6 points) of Black Earth Creek (appendix 4). Although all SNTEMP input variables were initially considered calibration parameters, the greatest change to simulated daily mean stream temperatures was caused by adjusting air temperature, streamflow, groundwater discharge, and groundwater temperature through lateral accretion. Of these four variables, air and groundwater temperature were both measured values and thus were considered relatively well known and not adjusted during calibration. Similarly, although streamflow was not directly measured at all locations, it was considered well constrained by the calibrated flows simulated by the coupled GSFLOW model. Trial-and-error calibration was considered complete when three criteria were met: (1) high correlation between simulated and observed daily mean stream temperatures, (2) minimal difference between average simulated and average observed stream temperatures, and (3) minimal difference between individual daily mean simulated and observed stream temperatures. Results for three locations are shown in figures 14 and 15.

When the complete 2005 time series is averaged at all calibration points within Black Earth Creek, simulated and observed daily mean stream temperatures have mean and root mean squared errors that are smaller than the $>5^{\circ} \mathrm{C}$ temperature range simulated (table 4). The overall trend of the time series is also well represented, as evidenced by a high correlation coefficient (table 4) indicating that modeled stream temperatures respond similarly to fluctuations in air temperature and surface discharge as do measured stream temperatures, though not necessarily with the same magnitude. In terms of model performance by day rather than entire period, the simple SNTEMP model was less able to characterize the general system dynamics (percent of total days where daily mean stream temperatures differed from observed temperatures by $\pm 1{ }^{\circ} \mathrm{C}$ or more in table 4). Previous SNTEMP studies on larger rivers indicate a mean error calibration target of $\pm 0.5^{\circ} \mathrm{C}$ (Bartholow, 1989). This target is met when all combined reaches are considered; however, Garfoot Creek and the unnamed tributary were slightly outside the $0.5{ }^{\circ} \mathrm{C}$ threshold (GC-034 and UT-037 in table 4). Garfoot Creek had the greatest mean error at $0.9^{\circ} \mathrm{C}$, largely due to consistently overestimated stream temperatures during June through July.

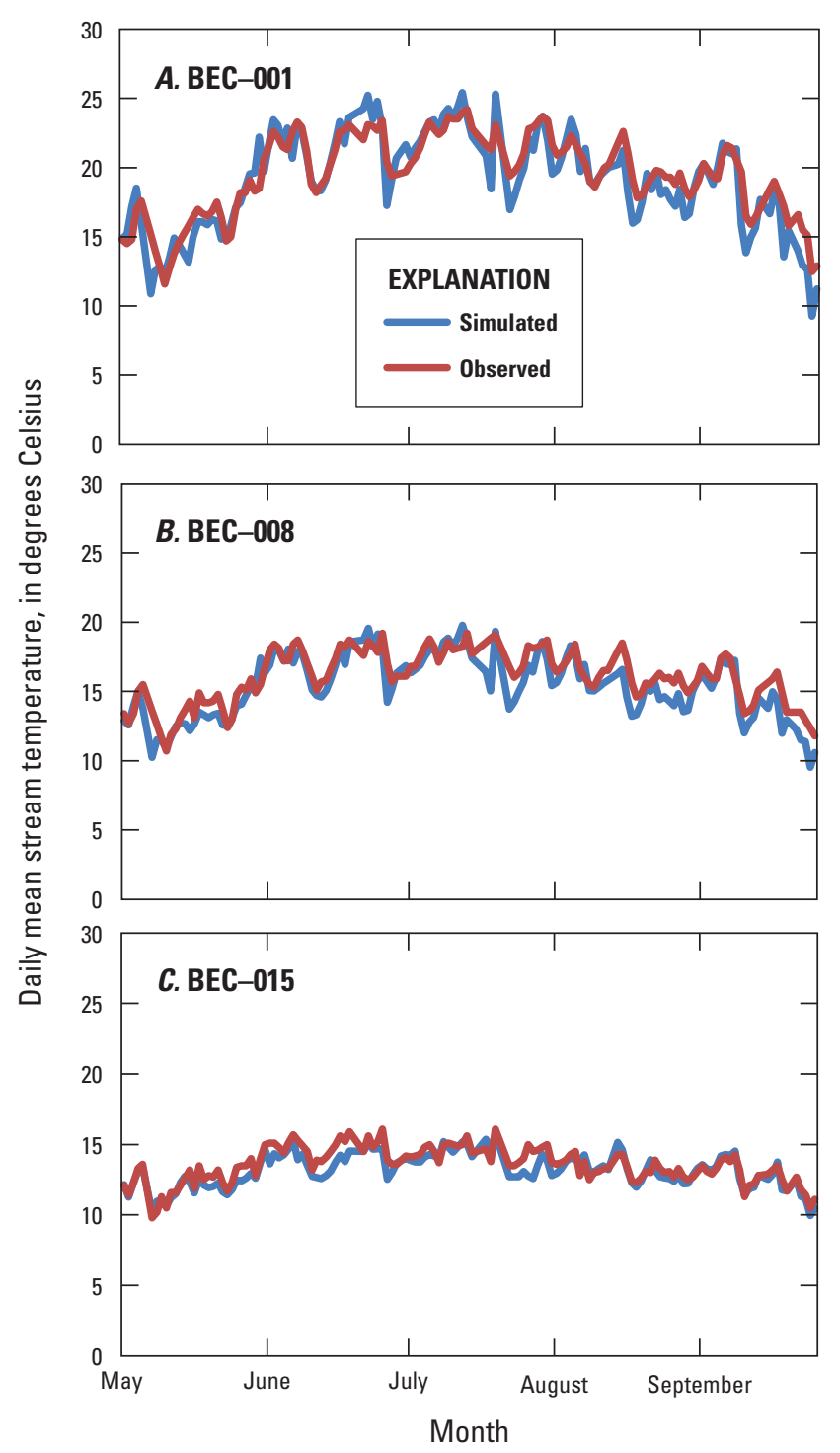

Figure 14. Simulated and observed daily mean stream temperatures at select locations in Black Earth Creek, MaySeptember 2005. $A$, stream reach BEC-001. $B$, stream reach BEC-008. $C$, stream reach $B E C-015$.

Daily differences are generally greatest at the warmer, downstream reaches of Black Earth Creek than the colder, groundwater-dominated zones in the upper reaches where changes in air temperature have less of an effect on stream temperatures over short time periods. The difference between observed and simulated stream temperatures at three locations along the main stem of Black Earth Creek is shown in figure 16. The upper reaches of Black Earth Creek (east of Cross Plains) generally remained within $1{ }^{\circ} \mathrm{C}$ of observed values throughout the entire calibration period; however, farther downstream, outside the influence of the strong groundwater discharge, observed temperatures tended to exhibit rapid changes that were not well matched by model predictions. All three locations show a similar response to changes in 


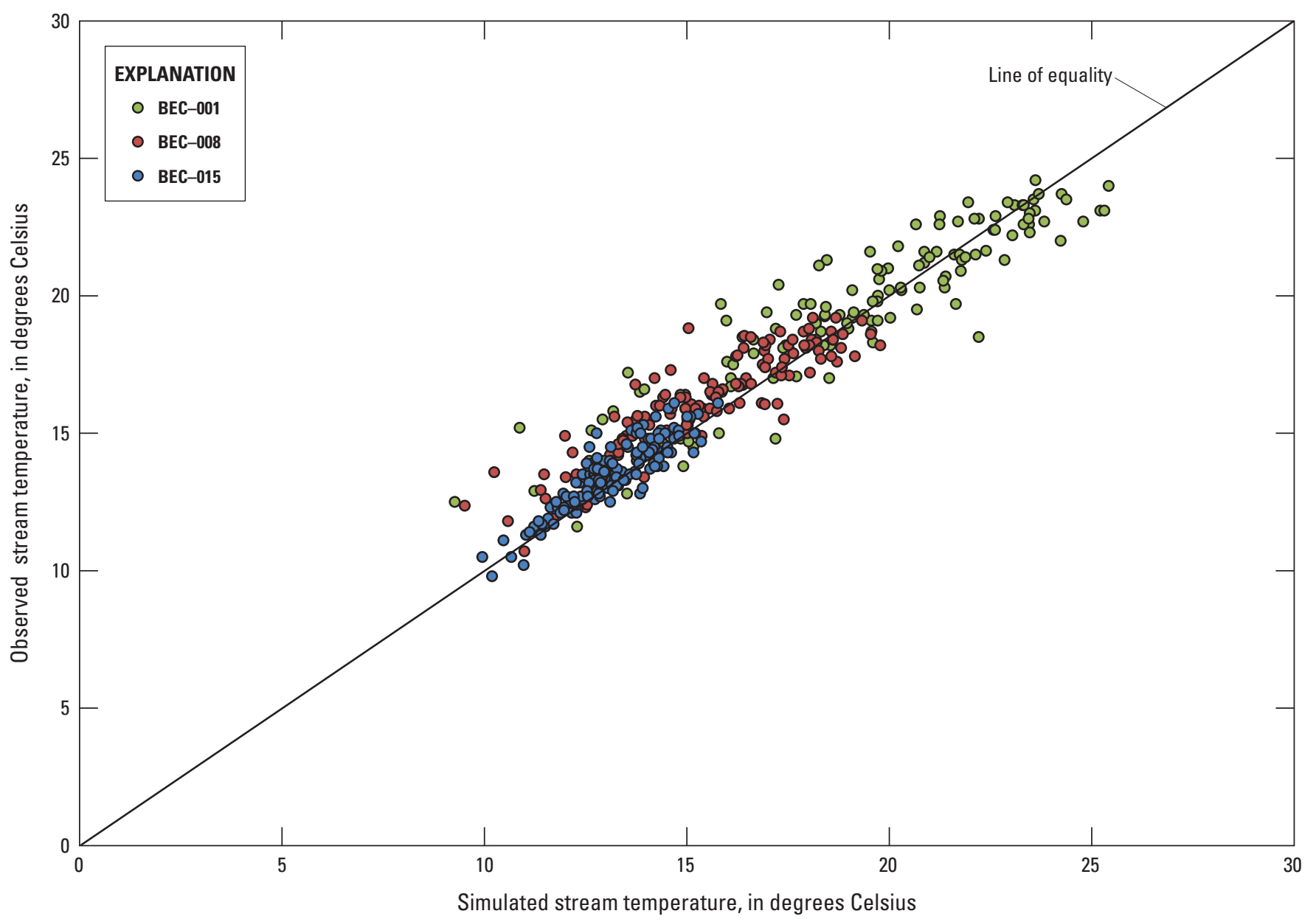

Figure 15. Comparison between simulated and observed daily mean stream temperatures at select locations in Black Earth Creek, May-September 2005.

air temperature, though with varying magnitude. The efficiency of transferring effects of rapid air-temperature change to stream temperature is expected to be only approximately simulated, given the relatively coarse stream-reach discretization and piecewise-constant daily timestep of the model; that is, SNTEMP is a successive steady-state model in which one assumes that all input data, including meteorological and hydrological variables, can be represented by 24-hour averages. This assumption is often appropriate for large river systems that tend to exhibit gradually varying temperatures over time, thereby containing sufficient heat capacity to mitigate large short-term variations in air temperature; however, study reaches not buffered by the constant influx of groundwater are faster to respond to rapid changes in air temperature, having a time constant much shorter than 24 hours.

Adjustments to shading parameters had little effect on resulting model fits. Adjustments to stream width did facilitate closer fits to observed values. The variations required for improved fit were constrained by reasonable deviation from field observations for this parameter. Groundwater temperatures may vary by season with cooler temperatures in the spring, slowly warming over the course of the summer. Evidence of this is shown in figure 16 where simulated temperatures in the middle and lower reaches of Black Earth Creek tend to underestimate observed values (negative differences), especially in the later part of May through June. The trend begins to reverse toward the end of July and continues through August and September, the hottest months of the summer. Seasonal fluctuations in temperature measured at some monitoring wells generally ranged from 9 to $12^{\circ} \mathrm{C}$, May through September, respectively. Other monitoring wells showed little to no seasonal variation, remaining consistently at $10^{\circ} \mathrm{C}$. Applying seasonal changes to groundwater temperatures in SNTEMP showed improvement to predicted values in some reaches but deterioration in others. Additional information at key locations throughout the stream network would ultimately improve overall model prediction. Similarly, including the ability to add temperature to SNTEMP segments by way of GSFLOW overland flow and interflow may also help address temperature model performance. 
Table 4. Analysis of fit between simulated and observed daily mean stream temperatures at calibration points in SNTEMP for May through September 2005.

[RMSE, root mean square error; \pm , plus or minus]

\begin{tabular}{|c|c|c|c|c|c|}
\hline Stream node & Correlation coefficient & Mean error $\left({ }^{\circ} \mathrm{C}\right)$ & RMSE $\left({ }^{\circ} \mathrm{C}\right)$ & Maximum error $\left({ }^{\circ} \mathrm{C}\right)$ & Percent days $\pm 1^{\circ} \mathrm{C}$ \\
\hline BEC-015 & 0.92 & 0.1 & 0.5 & 1.4 & 3.6 \\
\hline BEC-014 & 0.92 & 0.1 & 0.7 & -2.1 & 14.6 \\
\hline BEC-013 & 0.82 & 0.5 & 1.1 & 3.5 & 35 \\
\hline BEC-009 & 0.91 & -0.4 & 1.0 & -3.2 & 29 \\
\hline BEC-008 & 0.91 & 0.2 & 1.2 & -3.4 & 37 \\
\hline BEC-007 & 0.91 & 0.0 & 1.3 & -3.8 & 39 \\
\hline BEC-005 & 0.91 & -0.1 & 1.3 & -3.8 & 42 \\
\hline BEC-004 & 0.92 & 0.1 & 1.4 & 4.6 & 48 \\
\hline BEC-001 & 0.92 & -0.4 & 1.4 & -4.4 & 42 \\
\hline HPC-021 & 0.93 & 0.0 & 1.2 & -4.0 & 43 \\
\hline MV-027 & 0.93 & -0.4 & 1.1 & -3.1 & 37 \\
\hline $\mathrm{VC}-029$ & 0.83 & -0.2 & 1.6 & -5.0 & 47 \\
\hline GC-034 & 0.82 & 0.9 & 1.5 & 3.8 & 57 \\
\hline UT-037 & 0.73 & -0.7 & 1.3 & -3.5 & 42 \\
\hline BC-039 & 0.92 & -0.2 & 1.3 & -3.9 & 33 \\
\hline All combined reaches & 0.91 & -0.04 & 1.2 & -5.0 & 37 \\
\hline
\end{tabular}

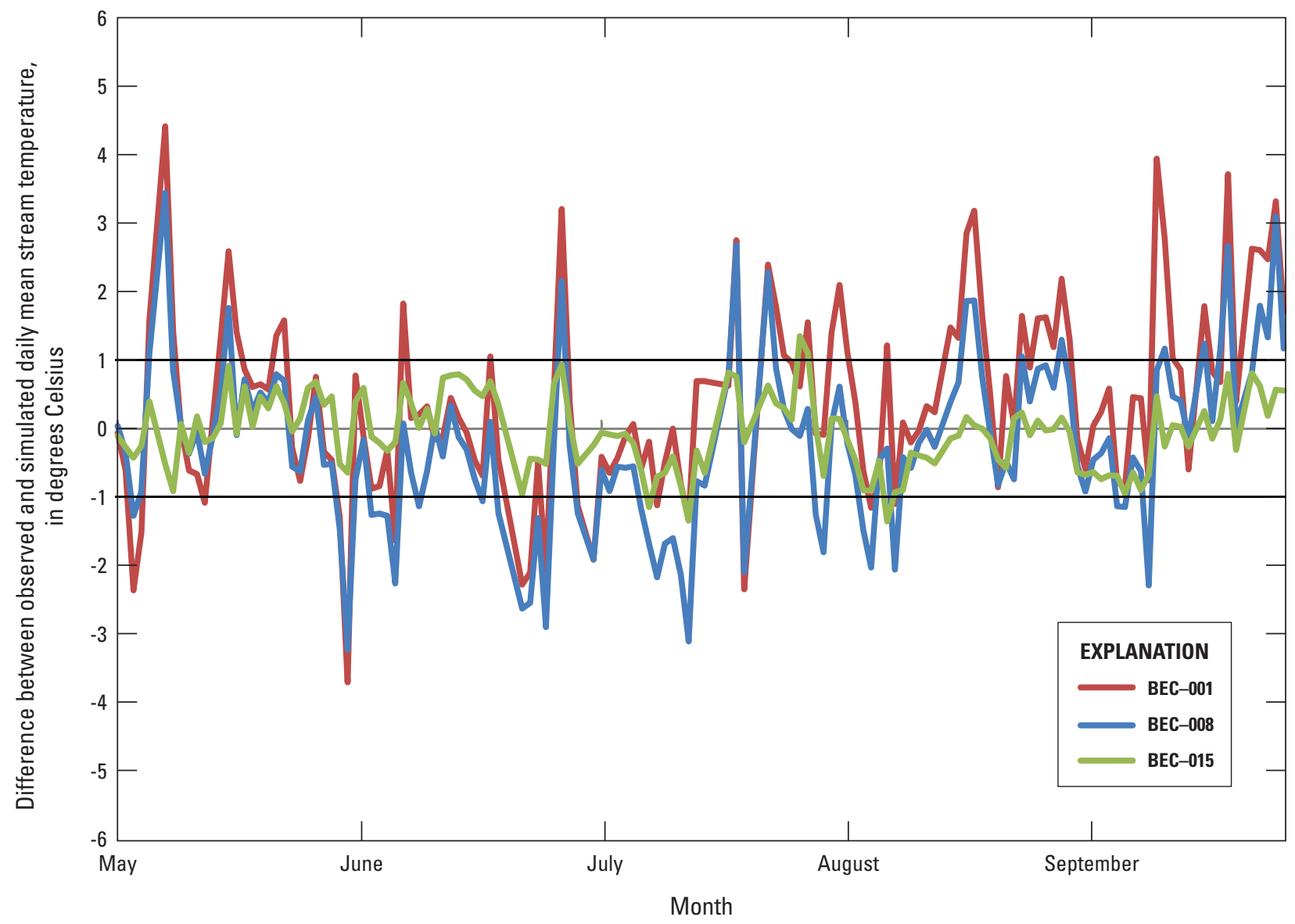

Figure 16. Difference between observed and simulated daily mean stream temperatures at select locations in Black Earth Creek, May-September 2005. 


\section{Climate-Change Effects}

Climate-change scenario forcings drove changes in GSFLOW and SNTEMP model outputs, including a general ecohydrological driver (growing-season length), streamflow, and stream temperature. In the presentation of climate-change effects, the overall uncertainty in the forecasts increases in many instances (that is, the overall envelope of results from the three emission scenarios is wider). This effect is primarily due to differences in the underlying assumptions among the three emission scenarios used in the climate-change evaluation (table 1) that become increasingly important in the latter part of the simulations.

\section{Changes to Growing-Season Length}

As is expected given the increase in maximum and minimum air temperatures (figs. $7 \mathrm{~A}$ and $7 \mathrm{~B}$ ), the length of the growing season generally lengthens on the order of weeks by 2100 for all emission scenarios (fig. 17), with the largest increases seen in the A1B and A2 scenarios (blue and red transparent areas, respectively, fig. 17). These values are comparable to those reported by Christiansen and others (2011) for the BEC area, which used the same algorithm for calculating growing season but a different source for downscaled GCM climate data.

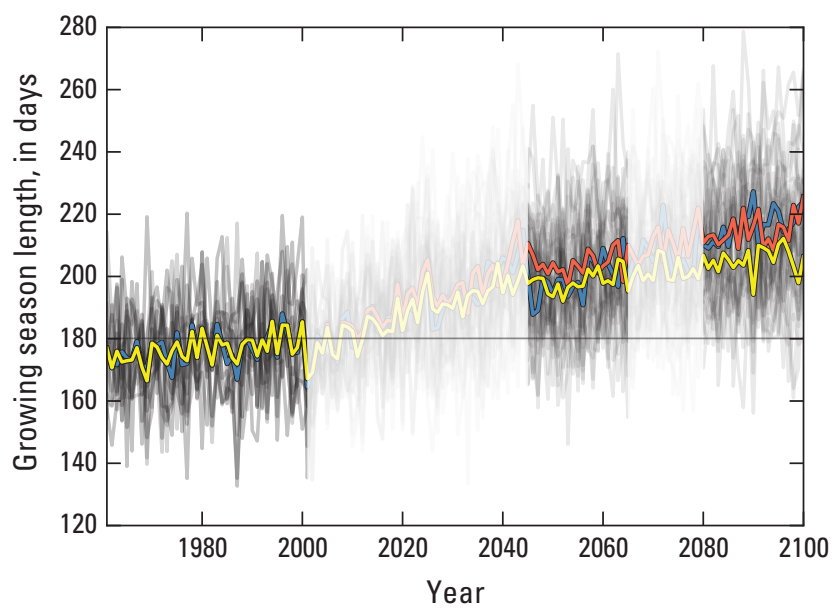

Figure 17. Change in growing-season length related to potential climate change, defined as the difference between the date of the first killing frost in the fall and the date of the last killing frost in the spring.

\section{Changes to Basin-Scale Hydrologic Flows and Storage}

Although estimates of future total precipitation did not show strong trends in the GCMs evaluated here (fig. 7C), the distribution of precipitation between rainfall and snowfall does show appreciable potential change (figs. 18A and 18B), in which reductions in annual snowfall occur concurrently with increases in annual rainfall. This combination is primarily a result of changes from late fall through winter, in which warmer temperatures result in more precipitation coming in the form of rainfall during the period when snowfall currently dominates. This reduction in snowfall reduces the amount of precipitation banked as snowpack (fig. 18C).

Increases in temperature also increase the annual potential ET amount (fig. 19A). Actual ET amounts (fig. 19B) show associated increases, but not to the same degree as potential ET. The discrepancy between potential and actual ET reflects water limitation in the soil zone during the summer periods when potential ET is highest; that is, the potential is strong for evapotranspiration to occur, but water in the soil zone may not be available (Weiss and Menzel, 2008). Moreover, longer growing seasons with warming temperatures also serve to decrease average soil moisture. The loss of soil moisture during the increase in potential and actual transpiration is shown in decreases in the annual average soil moisture (fig. 19C).

Standard output from the coupled model provides more temporal detail than annually averaged characterizations; indeed, the model results shown here are longer-term averages derived from model output with daily time step resolution. Although forecasts of daily future weather are not useful, synthesizing the daily model output into monthly averages gives a depiction of interannual variability that results from the GCM climate drivers. For example, the annual changes in potential ET, actual ET, and soil moisture can also be compared using monthly averages (fig. 20), including comparisons to current conditions (red line, fig. 20). Such a formulation is calculated using the last 5 years of the 20-year GCM period (to minimize spin-up artifacts), and shows that the annual changes shown in figure 19 are not equally expressed during all months (fig. 20). Moreover, this portrayal shows that an annual decrease in soil moisture (fig. 19C) results from expected wetter future months (January, February, fig. 20C) being offset with drier conditions during the other months of the year.

Average annual groundwater recharge (fig. 21) changed less than the actual ET and average annual soil moisture, reflecting the increase in rainfall and related recharge during the winter months (fig. 21C), which is a period of plant senescence. This result suggests a potential for future drying of surface-water-fed ecosystems (such as ephemeral wetlands), with relatively less drying occurring in ecosystems fed by the groundwater system (such as fens). 

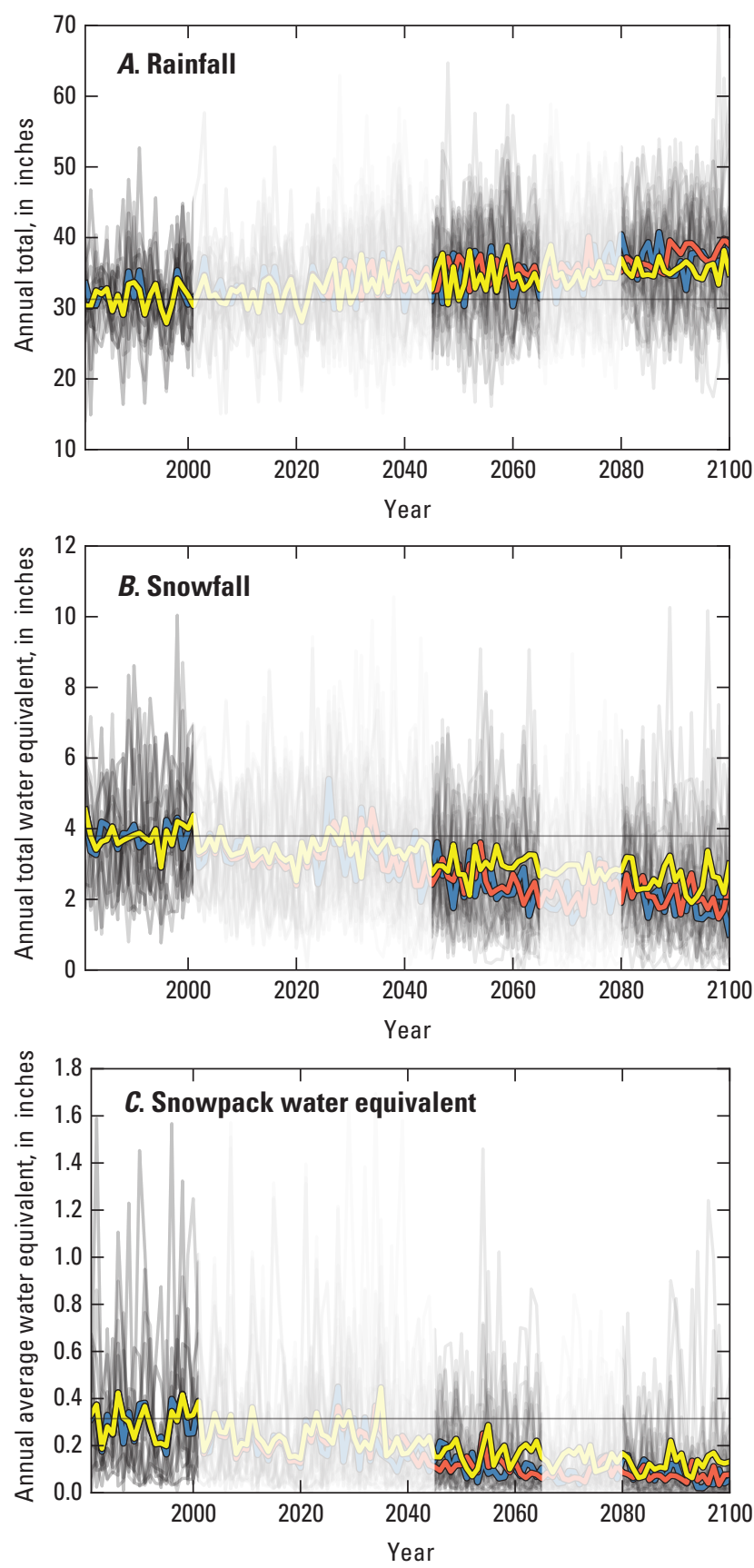

EXPLANATION

sresa1b

sresa2

sresb1

Figure 18. Climate-change scenario results for total volumes of $A$, rainfall; $B$, snowfall; and $C$, the resulting snowpack, normalized to the watershed area. The left-hand plot shows the time series of model results; synthetic climate used to infill between General Circulation Model (GCM) outputs are greyed out. Uncertainty within the GCM/ emission scenario time series is reflected by the envelope; the average of an emission scenario across GCMs is shown as a colored line. The horizontal line reflects measured current conditions calculated using the average of all GCMs and emission scenarios. The right-hand side shows a boxplot that distills the averages from the two GCM-reported future periods and compares them to current conditions.
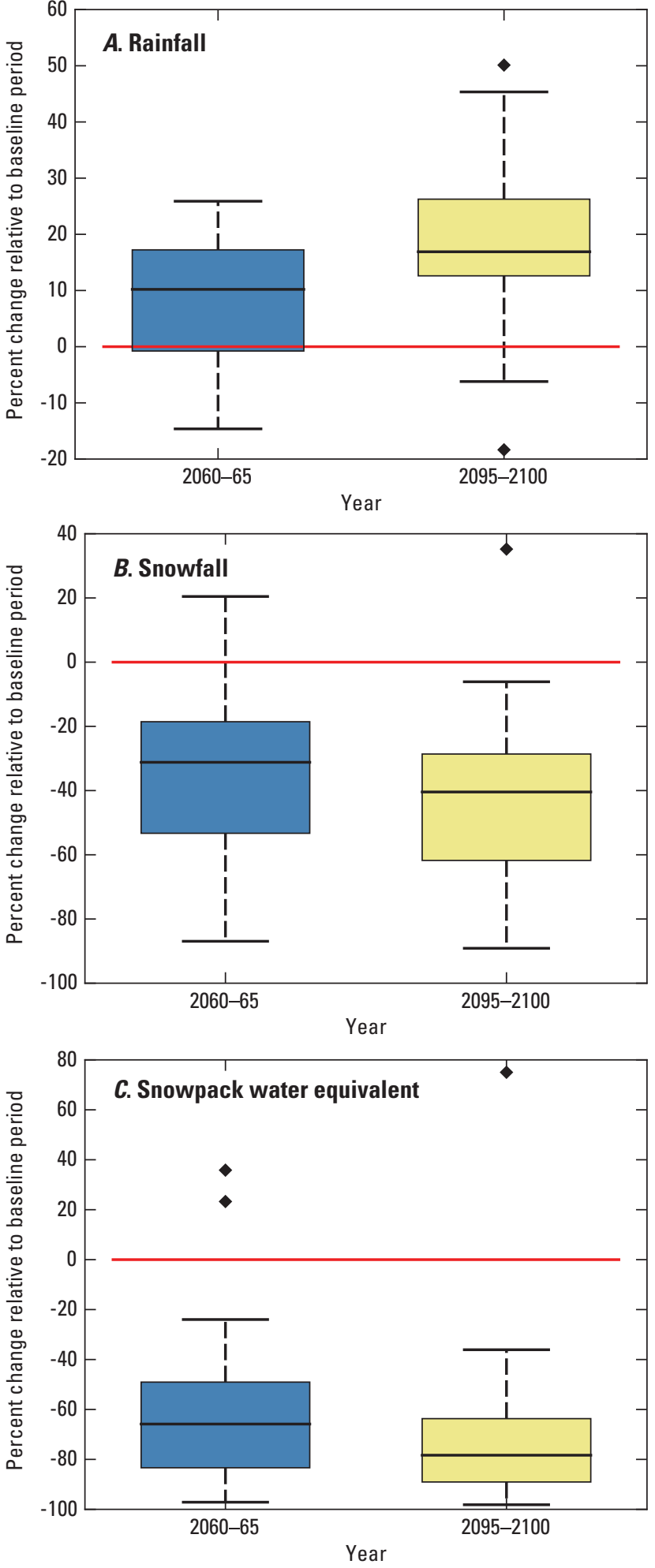

\section{EXPLANATION}

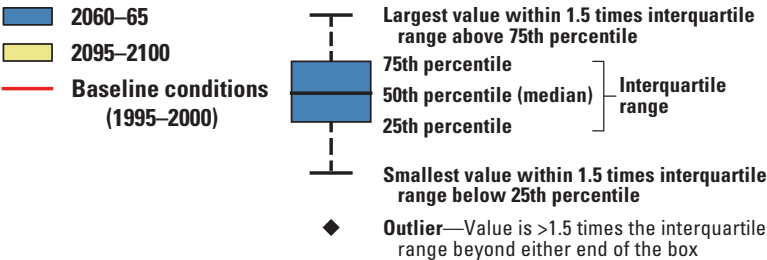



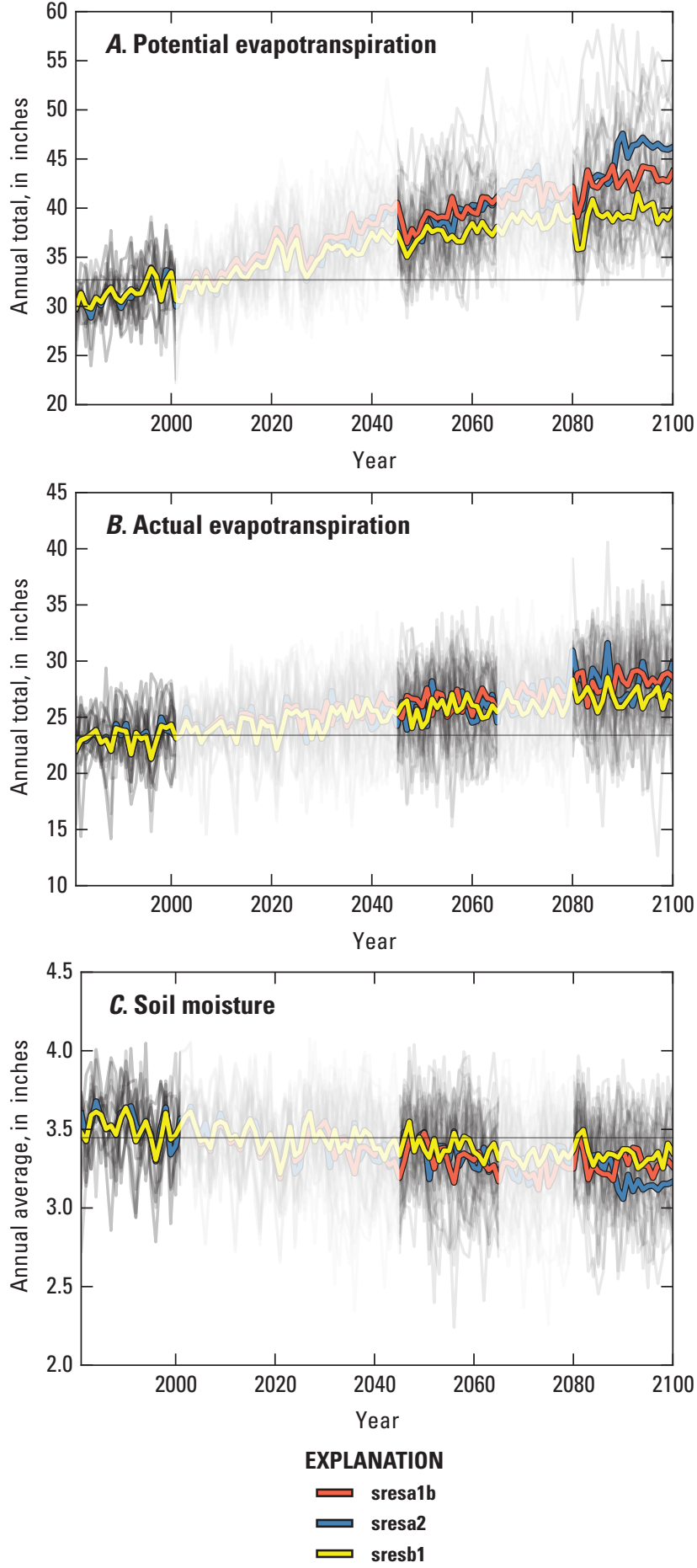

Figure 19. Climate-change scenario results for total volumes of $A$, potential and $B$, actual evapotranspiration; and $C$, the resulting watershed-wide average soil moisture, normalized to the watershed area. The left-hand plot shows the time series of model results; synthetic climate used to infill between General Circulation Model (GCM) outputs are greyed out. Uncertainty within each GCM/emission scenario time series is reflected by the envelope; the average of an emission scenario across GCMs is shown as a colored line. The horizontal line reflects measured the current conditions calculated using the average of all GCMs and emission scenarios. The right-hand side shows a boxplot that distills the averages from the two GCMreported future periods and compares them to current conditions.
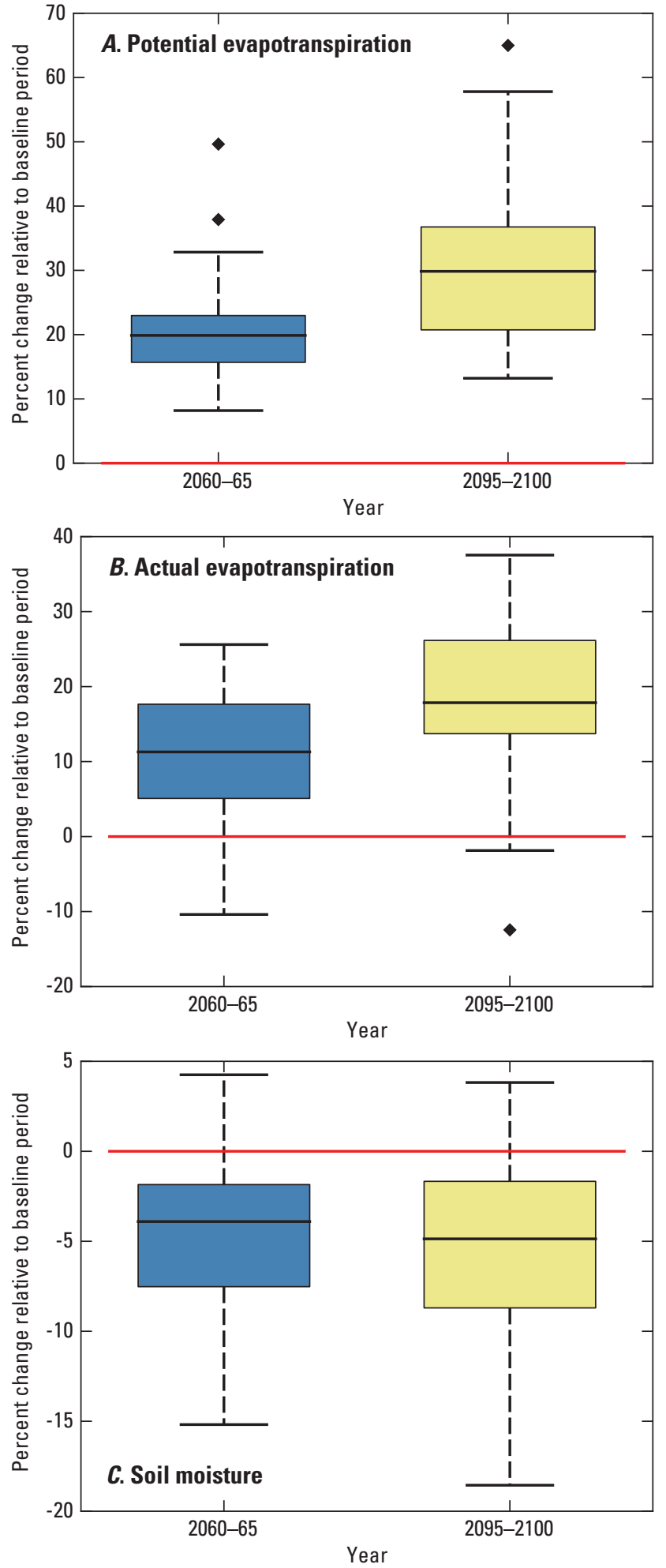

EXPLANATION

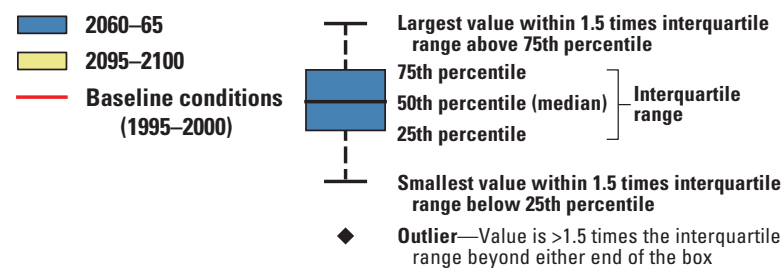




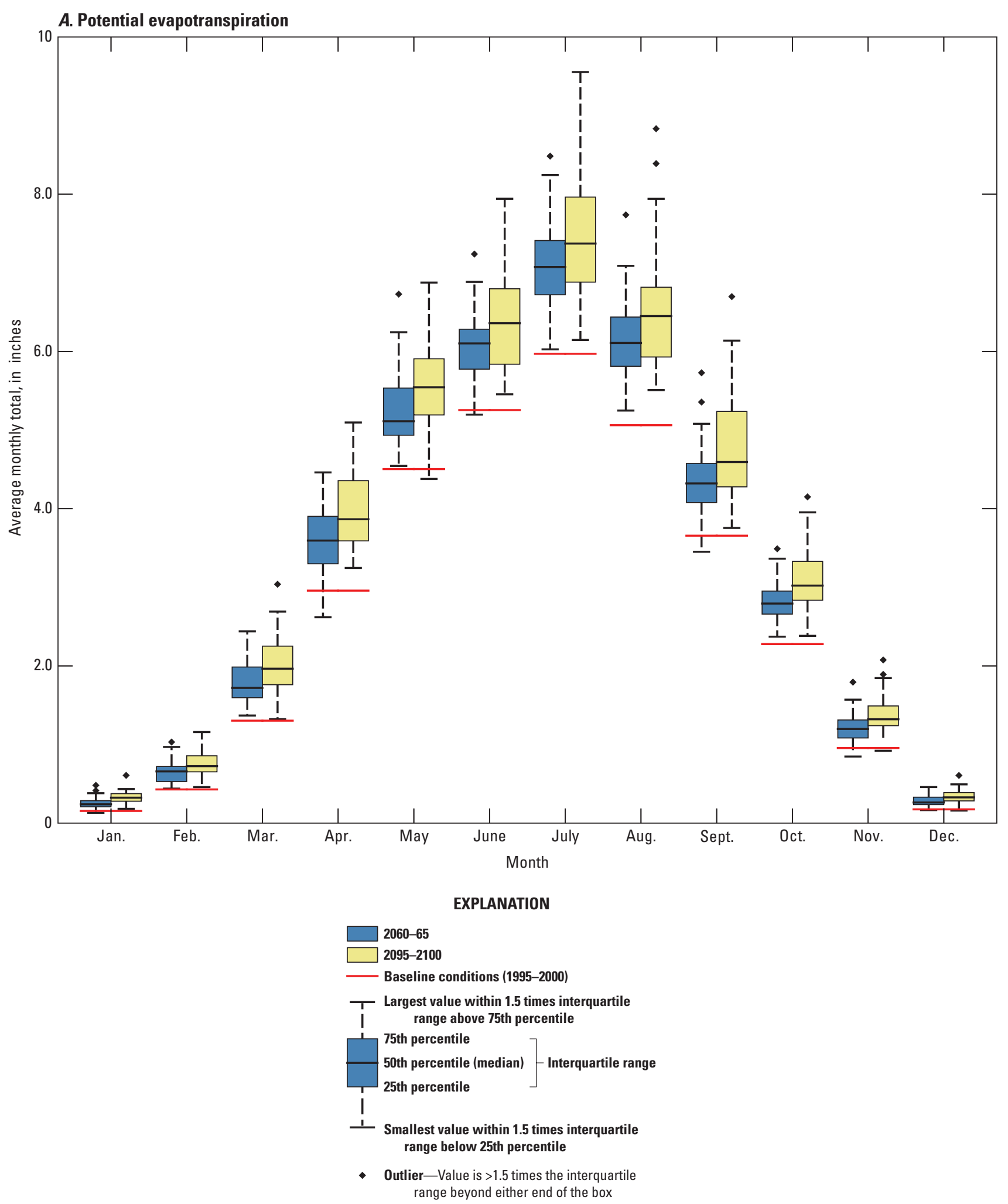

Figure 20. Climate-change scenario results for monthly watershedwide $A$, potential evapotranspiration; $B$, actual evapotranspiration; and $C$, resulting average soil moisture. The period 2060-65 is shown with the darker boxplot and 2095-2100 in the lighter boxplot. 


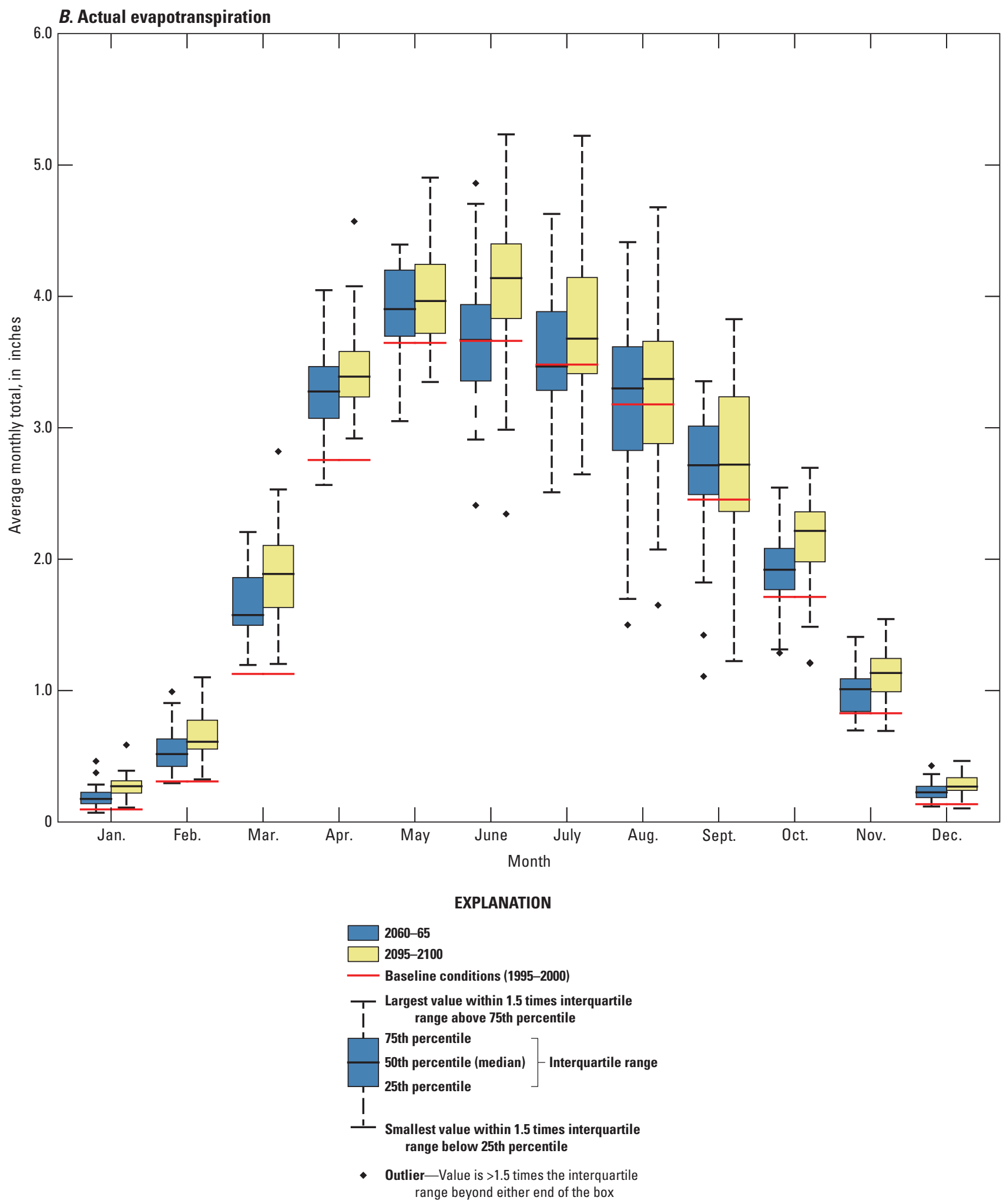

Figure 20. Climate-change scenario results for monthly watershedwide $A$, potential evapotranspiration; $B$, actual evapotranspiration; and $C$, resulting average soil moisture. The period 2060-65 is shown with the darker boxplot and 2095-2100 in the lighter boxplot.-Continued 


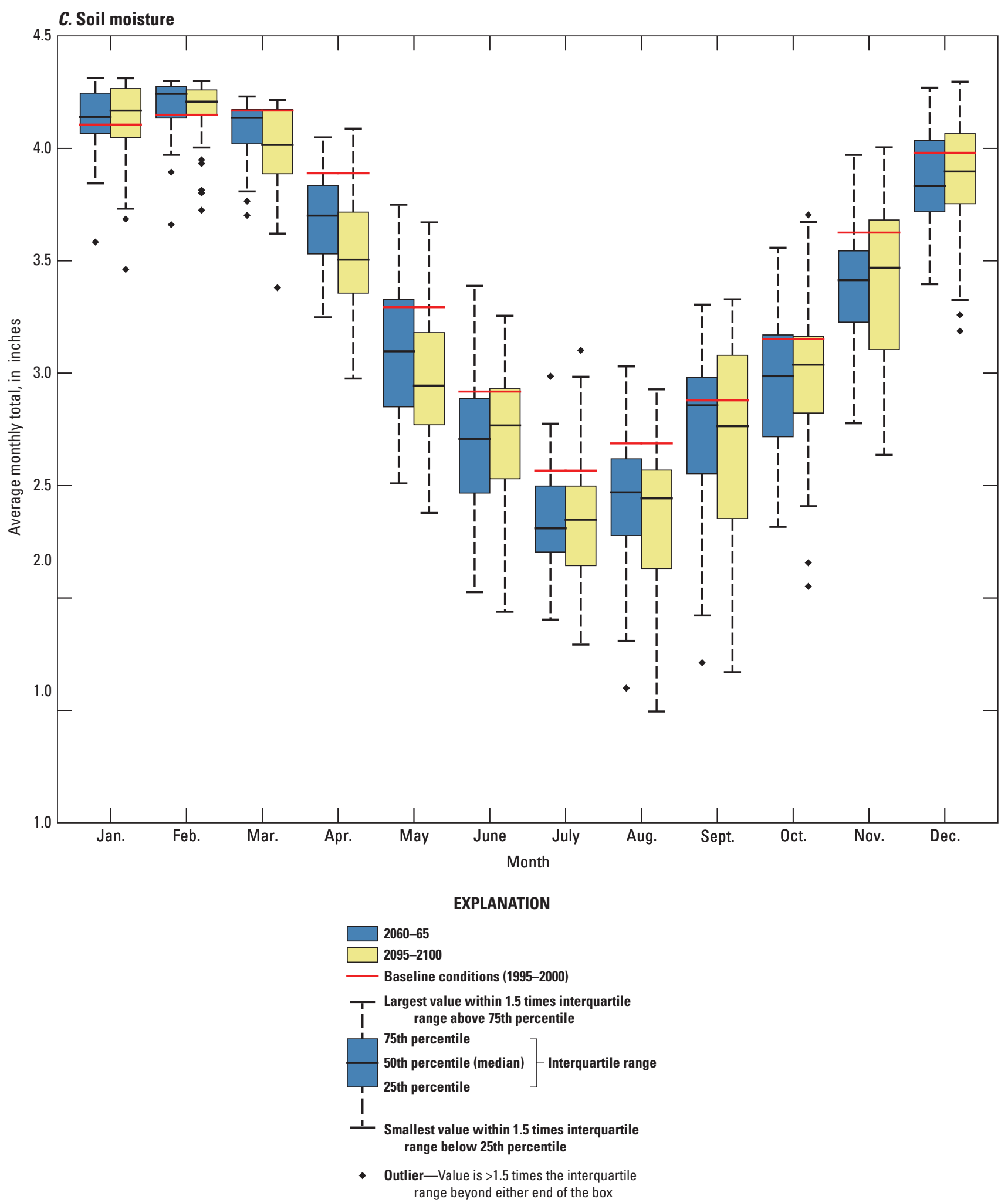

Figure 20. Climate-change scenario results for monthly watershedwide $A$, potential evapotranspiration; $B$, actual evapotranspiration; and $C$, resulting average soil moisture. The period 2060-65 is shown with the darker boxplot and 2095-2100 in the lighter boxplot.-Continued 

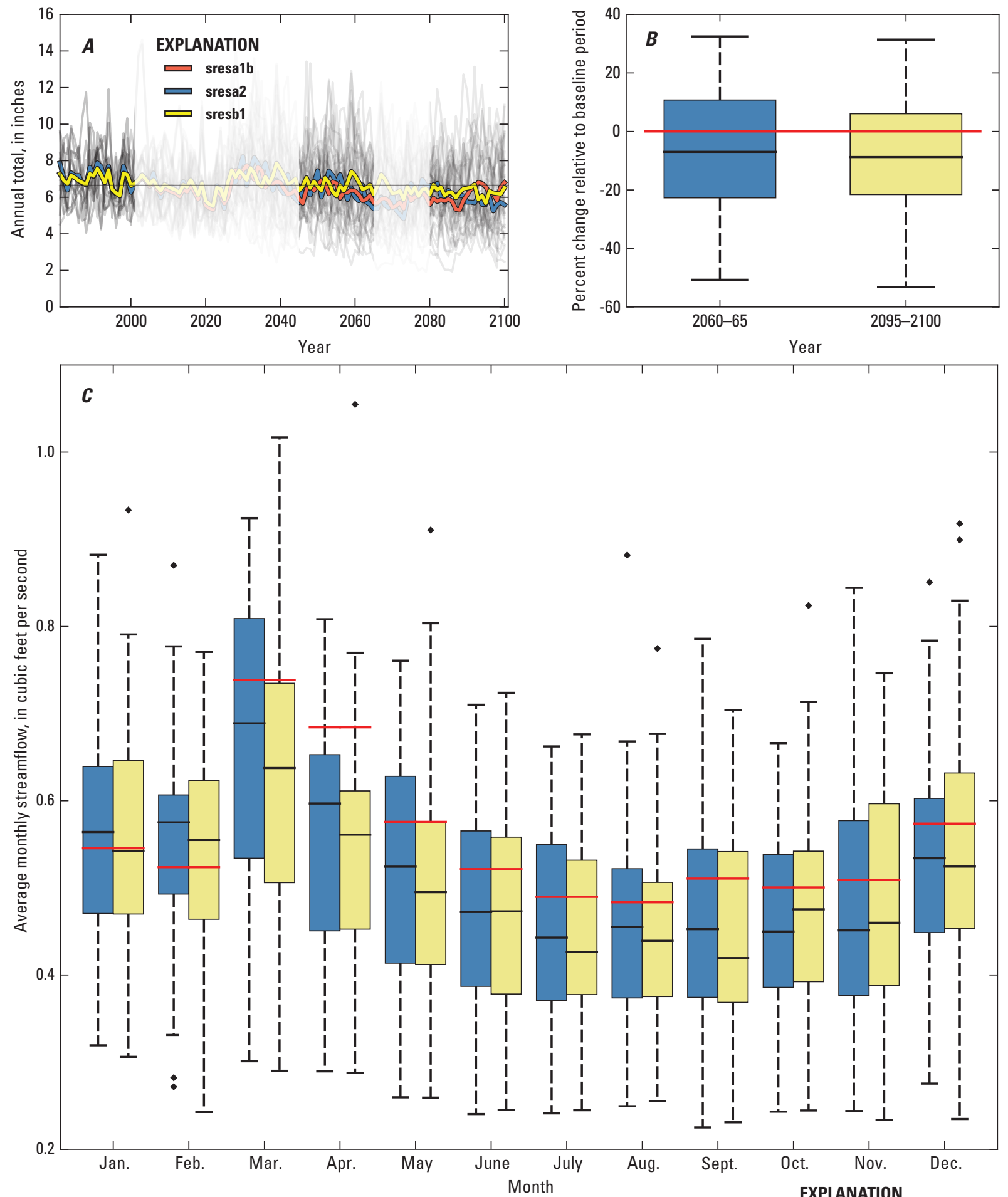

Figure 21. Climate-change scenario groundwater recharge results for watershedwide $A$, annual average time series; $B$, statistical summary; and $C$, monthly average recharge to the groundwater system. Panel $A$ shows the time series of model results; synthetic climate used to infill between General Circulation Model (GCM) outputs are greyed out. Uncertainty within the GCM/emission scenario time series is reflected by the envelope; the average of an emission scenario across GCMs is shown as a colored line. The horizontal line reflects measured the current conditions calculated using the average of all GCMs and emission scenarios. Panel $B$ and $C$ show a boxplot that distills the averages from the two GCMreported future periods (2060-65 and 2095-2100) and compares them to current conditions.

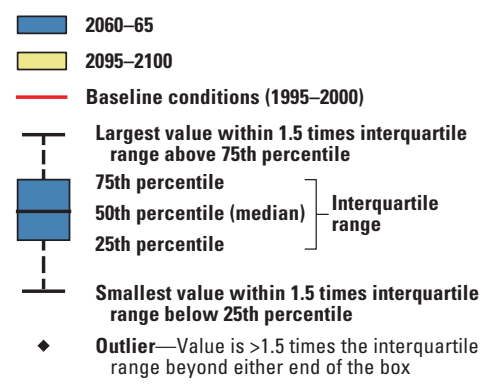




\section{Changes to Streamflow}

Streamflows in the BEC watershed are forecast to decrease in response to the simulated climate change used here, suggesting that additional future precipitation (fig. 7C) will be more than offset by increases in actual ET (fig. 19B). For brevity, only the results from the long-running streamgage at the Village of Black Earth are shown; other locations in the watershed showed similar simulation magnitude and timing of response. Thus, the reduction in annual streamflow (fig. 22B) is generally seen during all months in the year (fig. 22C ), with large reductions during March and April. This flattening of the monthly streamflow with climate change is an expected result given the forecasted increase in maximum and minimum temperatures reducing the amount of snow banked during the winter (fig. 7A and 7B, respectively). Near the end of the 21st century, annual low streamflow (90-percent flow duration $\left[\mathrm{Q}_{90}\right]$ ) drops appreciably (fig. 23). Low flows typically occur during August when temperatures are high and thus can be a stress on the cold water fishery. Annual high streamflow (10-percent flow duration $\left[\mathrm{Q}_{10}\right]$ ) is also reduced (fig. 24), though the forecast reduction is not as large as for low flows; however, the average annual high flow shown in figure 24 does not reflect the short-term high flows associated with storm events (for example, precipitation shown in fig. 9B). Moreover, GCM forecasts are commonly poor predictors of future extreme events. Therefore, the results shown in figure 24 should not be equated to forecast reduction of flooding with climate change, especially given that extreme events may become more prevalent in the future due to increased system energy imparted by high temperatures.

\section{Changes to Spring Discharge East of the Village of Cross Plains}

East of the Village of Cross Plains, measured streamflow approximately doubles over a short stream segment as a result of large groundwater discharge to a series of springs located in the streambed of Black Earth Creek. This phenomenon relates to the area being located at the terminus of continental glaciation (fig. 3), where the BEC valley is thinnest as it enters the unglaciated area of the watershed. This narrowing of the valley results in lower hydraulic conductivity bedrock "pinching" the groundwater system flowing westward in the higher conductivity glacio-fluvial sediments. This constriction, in turn, partially dams groundwater flow resulting in enhanced groundwater discharge to Black Earth Creek upstream of the constriction. This enhanced groundwater discharge is important for the cold-water fishery of Black Earth Creek (Novitzki, 1973) and is likely a source of system resiliency that results in a State of Wisconsin designation of Exceptional and Outstanding Water Resource downstream. Using the potential future climates from the GCMs to drive the coupled model shows that this area is projected to have a greater than 20 percent reduction in groundwater discharge (fig. 25), though with considerable uncertainty provided by the outlier results (the "whiskers" on the boxplots in fig. 25).

\section{Changes to Groundwater Levels}

As might be expected by the general drying of the system with simulated climate change, groundwater levels (or groundwater "heads") are forecast to decline appreciably across the BEC watershed. Upstream from springs near Cross Plains, the shallow water table is forecast to decline on the order of 15 feet by 2100 (fig. 26A), whereas the nearby deep Mt. Simon aquifer groundwater level is forecast to decline on the order of 20 feet during the same period (fig. 26B). In the middle portion of the watershed in the upper Paleozoic bedrock aquifer, the decline is forecast to be on the order 8 feet by 2100 (fig. 26C). These results indicate that drying will be more pronounced in areas where the upper groundwater system has high hydraulic conductivity, as is the case for the wells shown in figures $26 \mathrm{~A}$ and $26 \mathrm{~B}$.

\section{Changes to Stream Temperature}

All GCM models and scenarios result in a general increase in annual average stream temperatures during the 20-year simulation periods of 2046-65 and 2081-2100 (fig. 27). To simplify presentation, the annual average represents only May through September of each year. This value was chosen because it reflects a time when elevated and sustained stream temperatures are most likely, presenting an environment in which trout and other cold-water species are most vulnerable. On the basis of the GCM scenario averages (solid lines in fig. 27), the upper reaches of Black Earth Creek (BEC-015, table 4) remain the coolest of the three stream locations but have the largest amount of relative increase in annual average stream temperature (ranging from 2.9 to $5.7^{\circ} \mathrm{C}$ depending on GCM emission scenario). Smaller relative increases in simulated stream temperatures occur progressively downstream, ranging from 2.1 to $4.2^{\circ} \mathrm{C}$ at BEC-008 and 1.8 to $3.5^{\circ} \mathrm{C}$ at $\mathrm{BEC}-001$ (fig. 27). The $\mathrm{A} 2$ (red) and $\mathrm{A} 1 \mathrm{~B}$ (blue) emission scenarios show the largest gains in average stream temperature. A similar rate of increase between these two emission scenarios is evident during the first simulation period of 2046-65; however, the second simulation period of 2081-2100 shows a flattening of temperatures in the A1B emission scenario, whereas the A2 scenario continues to increase. The B1 emission scenario increases steadily in average annual stream temperatures, but the rate of change is less than that of the other scenarios and gains during the entire simulation period are the smallest. Similar to future forecasts of streamflow, stream temperature shows increasing variability (and thus uncertainty) across the scenarios as compared to current conditions (2000-10) for all modeled streams. 

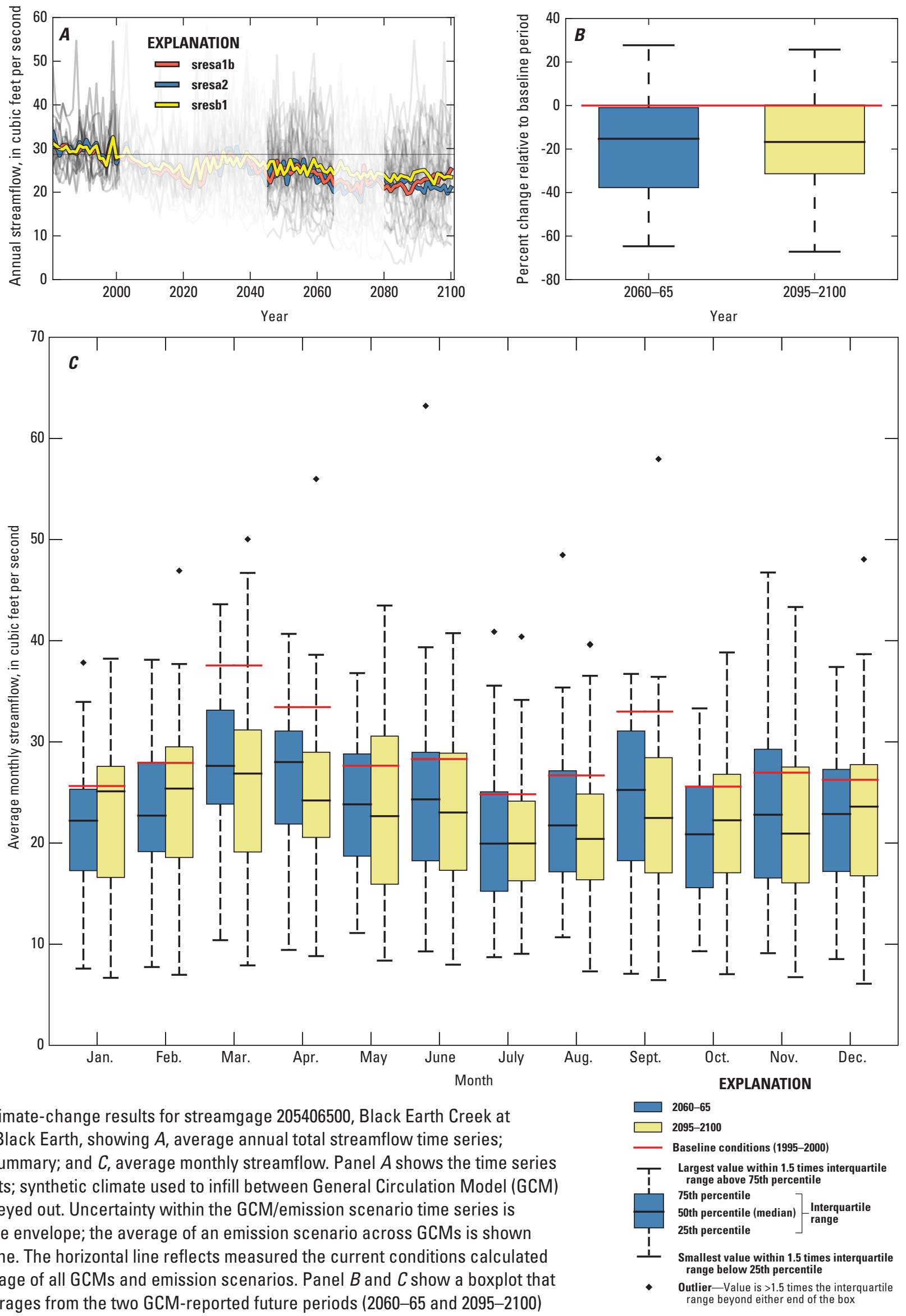

Figure 22. Climate-change results for streamgage 205406500, Black Earth Creek at the Village of Black Earth, showing $A$, average annual total streamflow time series; $B$, statistical summary; and $C$, average monthly streamflow. Panel $A$ shows the time series of model results; synthetic climate used to infill between General Circulation Model (GCM) outputs are greyed out. Uncertainty within the GCM/emission scenario time series is reflected by the envelope; the average of an emission scenario across GCMs is shown as a colored line. The horizontal line reflects measured the current conditions calculated using the average of all GCMs and emission scenarios. Panel $B$ and $C$ show a boxplot that distills the averages from the two GCM-reported future periods (2060-65 and 2095-2100) range beyond either end of the box and compares them to current conditions. 


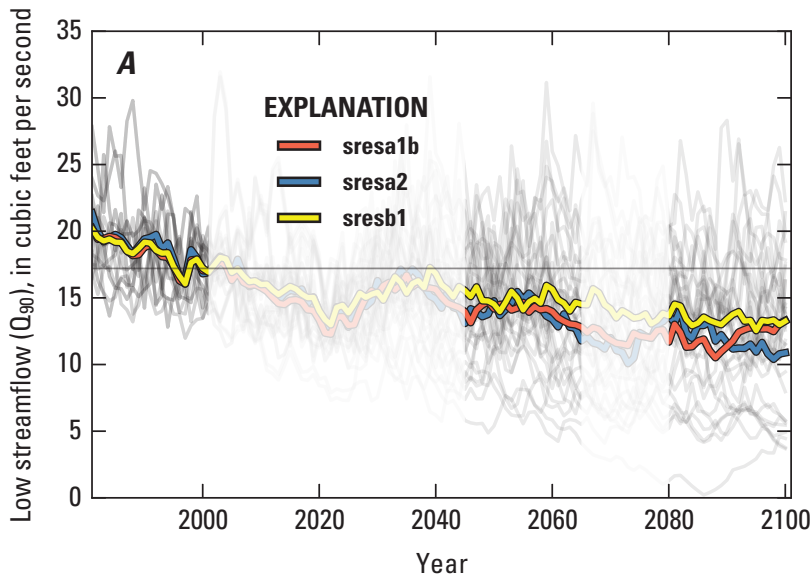

Figure 23. Climate-change results for streamgage 205406500, Black Earth Creek at the Village of Black Earth, showing average annual low $\left(0_{90}\right)$ streamflow. $A$, The left-hand panel shows the time series of model results; synthetic climate used to infill between General Circulation Model (GCM) outputs are greyed out. Uncertainty within the GCM/ emission scenario time series is reflected by the envelope; the average of an emission scenario across GCMs is shown as a colored line. The horizontal line in the left panel reflects measured the current conditions calculated using the average of all GCMs and emission scenarios. $B$, The right-hand panel shows a boxplot that distills the averages from the two GCM-reported future periods and compares them to current conditions.

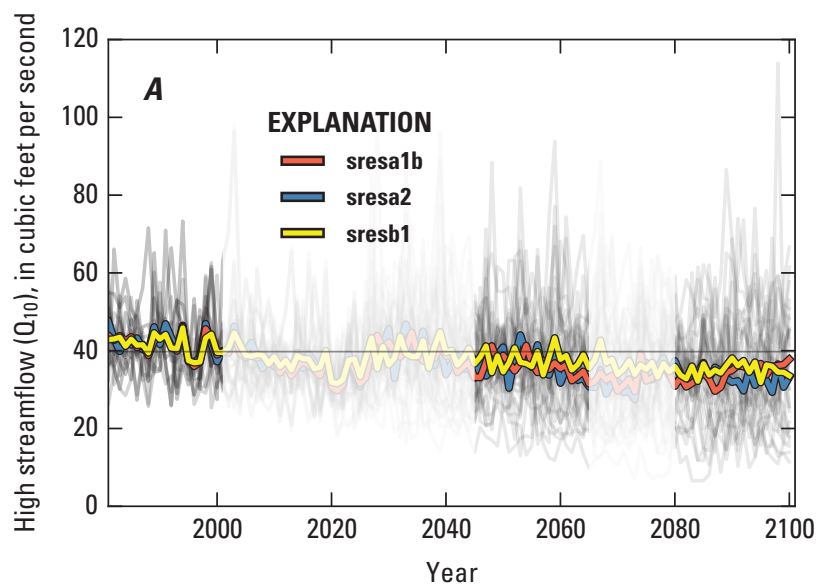

Figure 24. Climate-change results for streamgage 205406500, Black Earth Creek at the Village of Black Earth, showing average annual high $\left(0_{10}\right)$ streamflow. $A$, The left-hand panel shows the time series of model results; synthetic climate used to infill between General Circulation Model (GCM) outputs are greyed out. Uncertainty within the GCM/ emission scenario time series is reflected by the envelope; the average of an emission scenario across GCMs is shown as a colored line. The horizontal line in the left panel reflects measured the current conditions calculated using the average of all GCMs and emission scenarios. $B$, The right-hand panel shows a boxplot that distills the averages from the two GCM-reported future periods (2060-65 and 2095-2100) and compares them to current conditions.

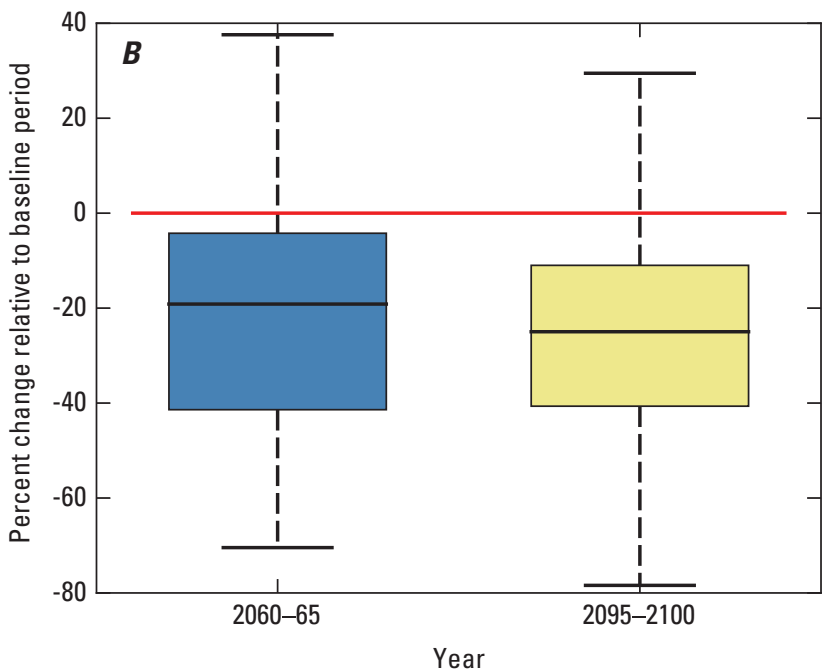

EXPLANATION
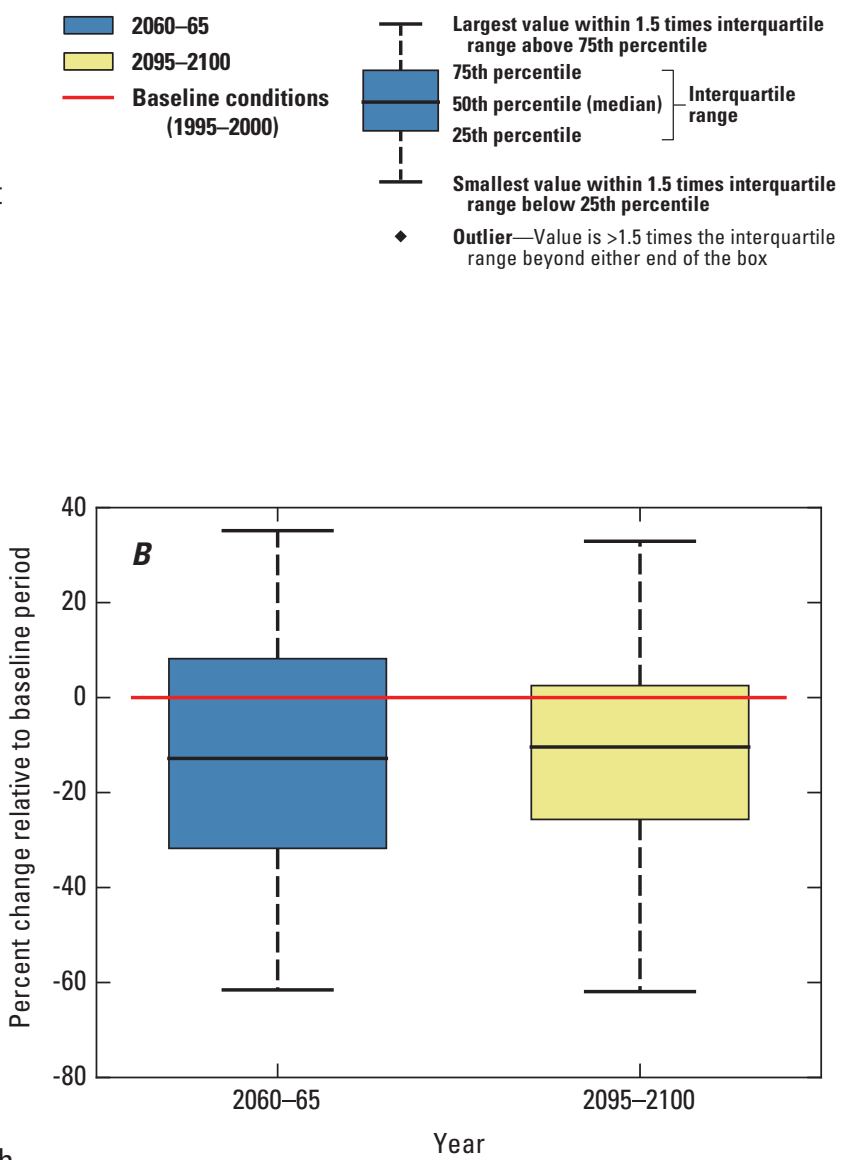

EXPLANATION

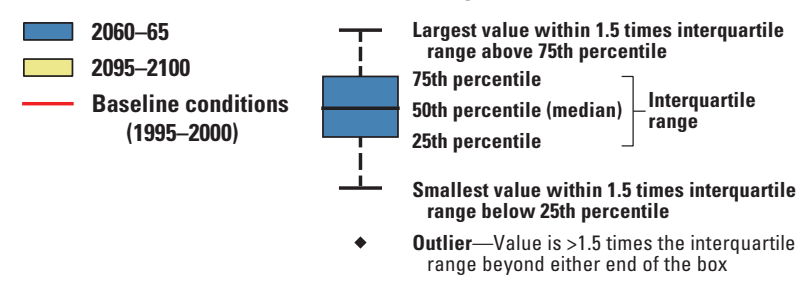



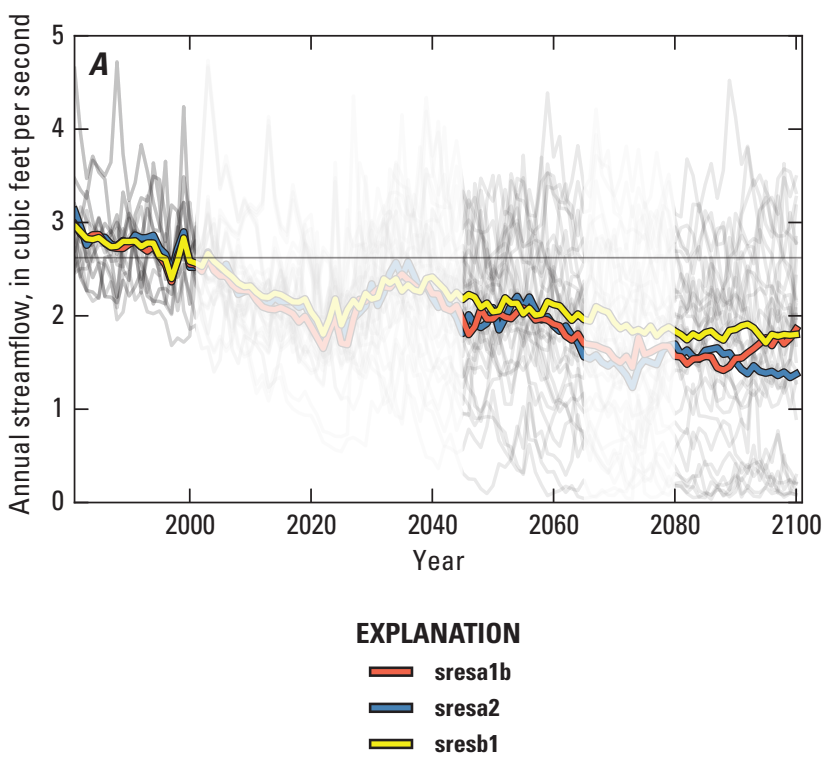

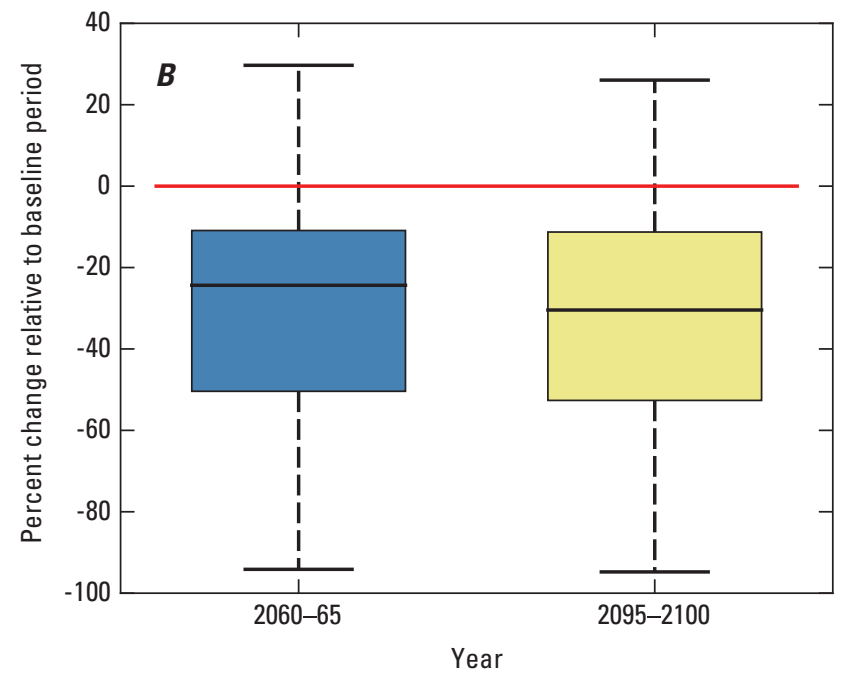

EXPLANATION

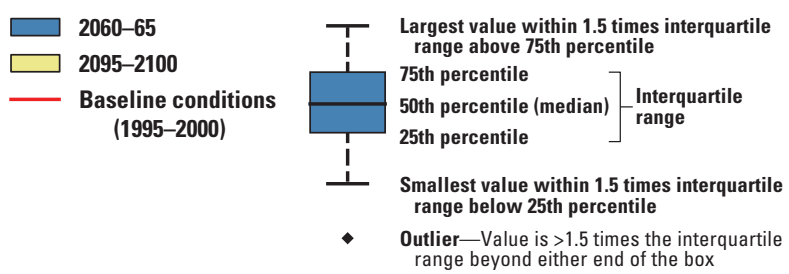

Figure 25. Climate-change results for the springs area east of the Village of Cross Plains. $A$, The left-hand panel shows the time series of model results; synthetic climate used to infill between General Circulation Model (GCM) outputs are greyed out. Uncertainty within the GCM/emission scenario time series is reflected by the envelope; the average of an emission scenario across GCMs is shown as a colored line. The horizontal line in the left panel reflects measured the current conditions calculated using the average of all GCMs and emission scenarios. $B$, The right-hand panel shows a boxplot that distills the averages from the two GCM-reported future periods and compares them to current conditions.

Increasing average stream temperatures as a result of climate change could present new challenges to maintaining Black Earth Creek as a cold-water fishery. Quantiles of daily mean stream temperatures representing the last 5 years of each simulation period (May through September only) were tabulated at BEC-001, BEC-008, and BEC-015 (table 5) as a way to estimate how often optimal temperatures needed to support a cold-water fishery are exceeded. Similar quantiles for the most recent measured daily mean stream temperature (2005 for BEC-001 and 2010-13 for BEC-008 and BEC-015) were estimated for comparison to represent current conditions. Using thresholds described by Bell (2006), each cell was color-coded to represent the optimal, upper critical, and upper incipient (lethal) stream temperatures generally tolerated by Salmo trutta (brown trout), a species commonly found throughout Black Earth Creek. The incidence of fish mortality may not necessarily occur for temperatures described as lethal in table 5 because the degree of thermal stress outside of these tolerance zones is a function of the exposure duration and rate at which temperature changes (Jonsson and Jonsson, 2009); moreover, the simulation looked at stream reaches and not localized groundwater discharge and associated cold-water refugia. Therefore, the information in table 5 should be used as a guideline and not as strict tolerances. The optimal range of stream temperature is currently met in the upper reaches of Black Earth Creek (BEC-015) but gradually enters a range of upper critical temperature toward the lower reaches (BEC-001). Optimal temperatures are exceeded with increasing frequency throughout the two simulation periods with greater occurrence in the A2 emission scenario. 

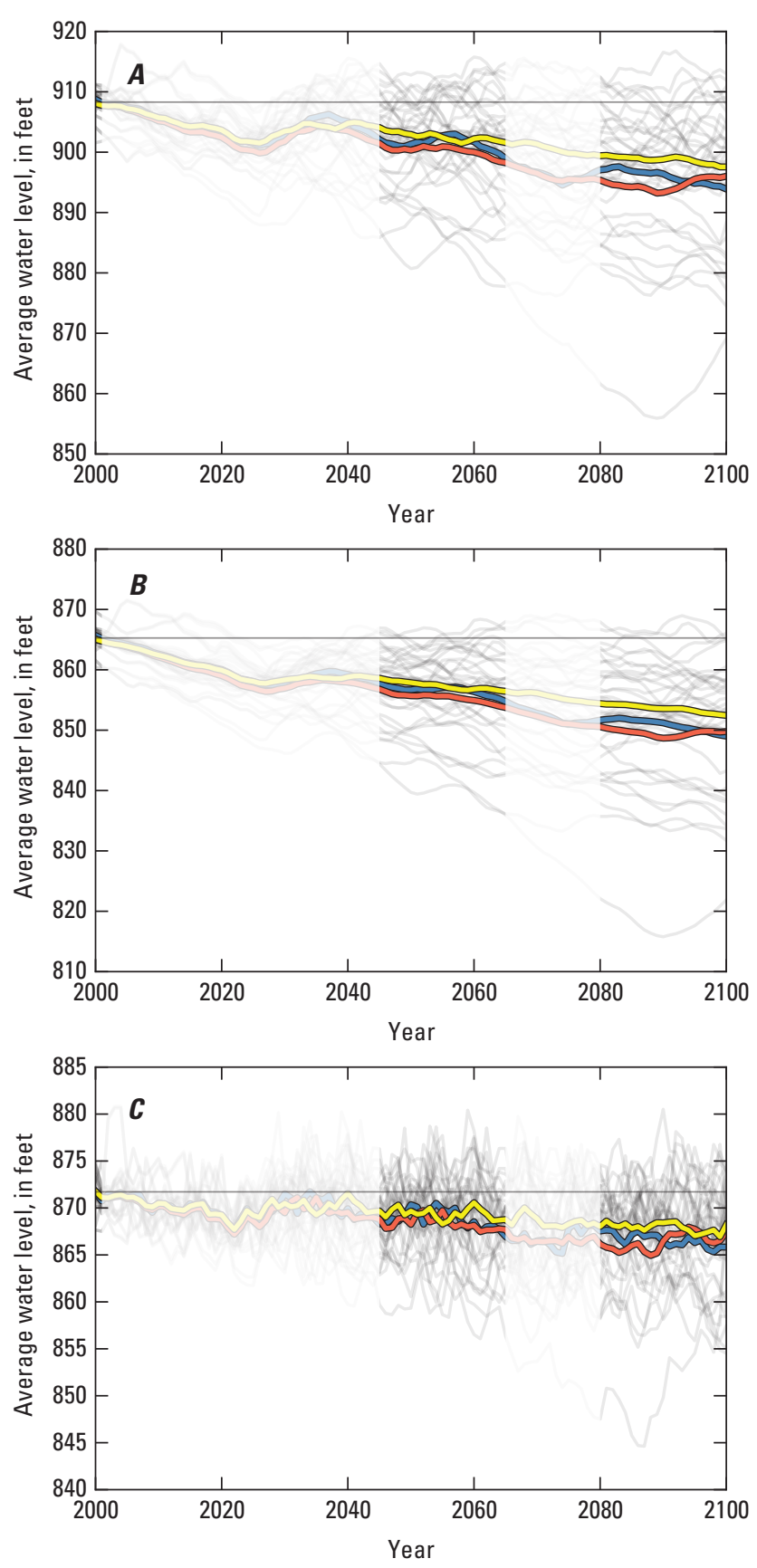

EXPLANATION

sresa1b

sresa2

ए sresb1

Figure 26. Forecast of groundwater levels for $A$, a shallow well in glacio-fluvial sediments located toward the upper portion of the watershed, $B$, a deep well open to the Mt. Simon bedrock aquifer in the upper portion of the watershed, and $C$, a well of intermediate depth open to the upper Paleozoic bedrock aquifer in the middle portion of the watershed near the Garfoot tributary. The left-hand panel reflects the forecast time series; the right-hand panel shows a boxplot summary of the left-hand time series.
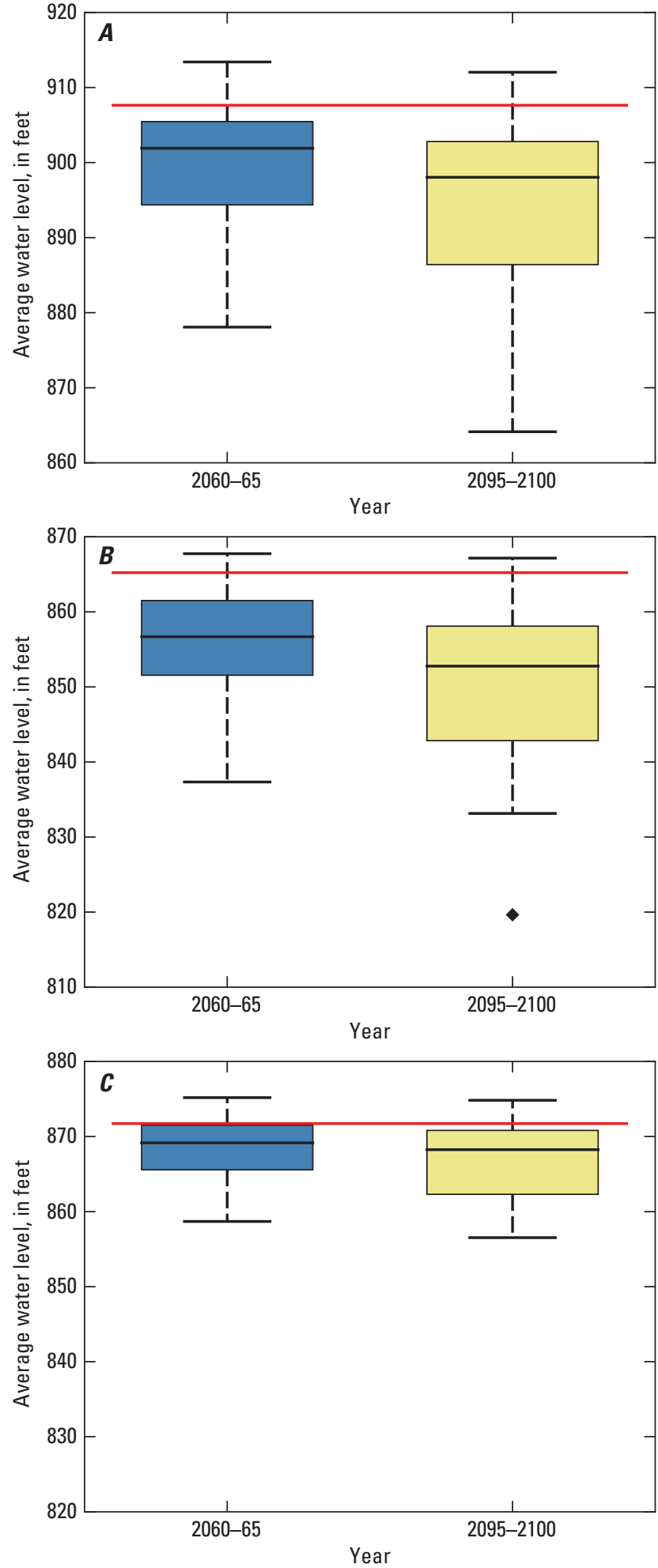

EXPLANATION

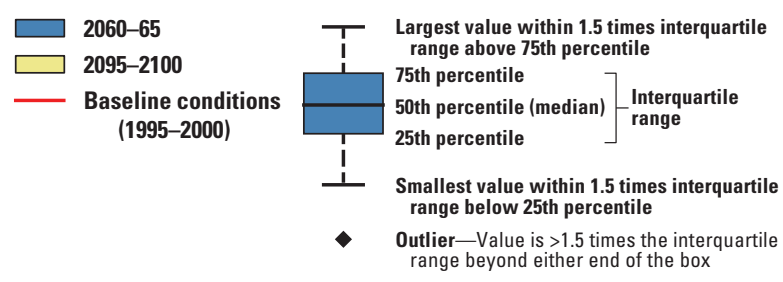



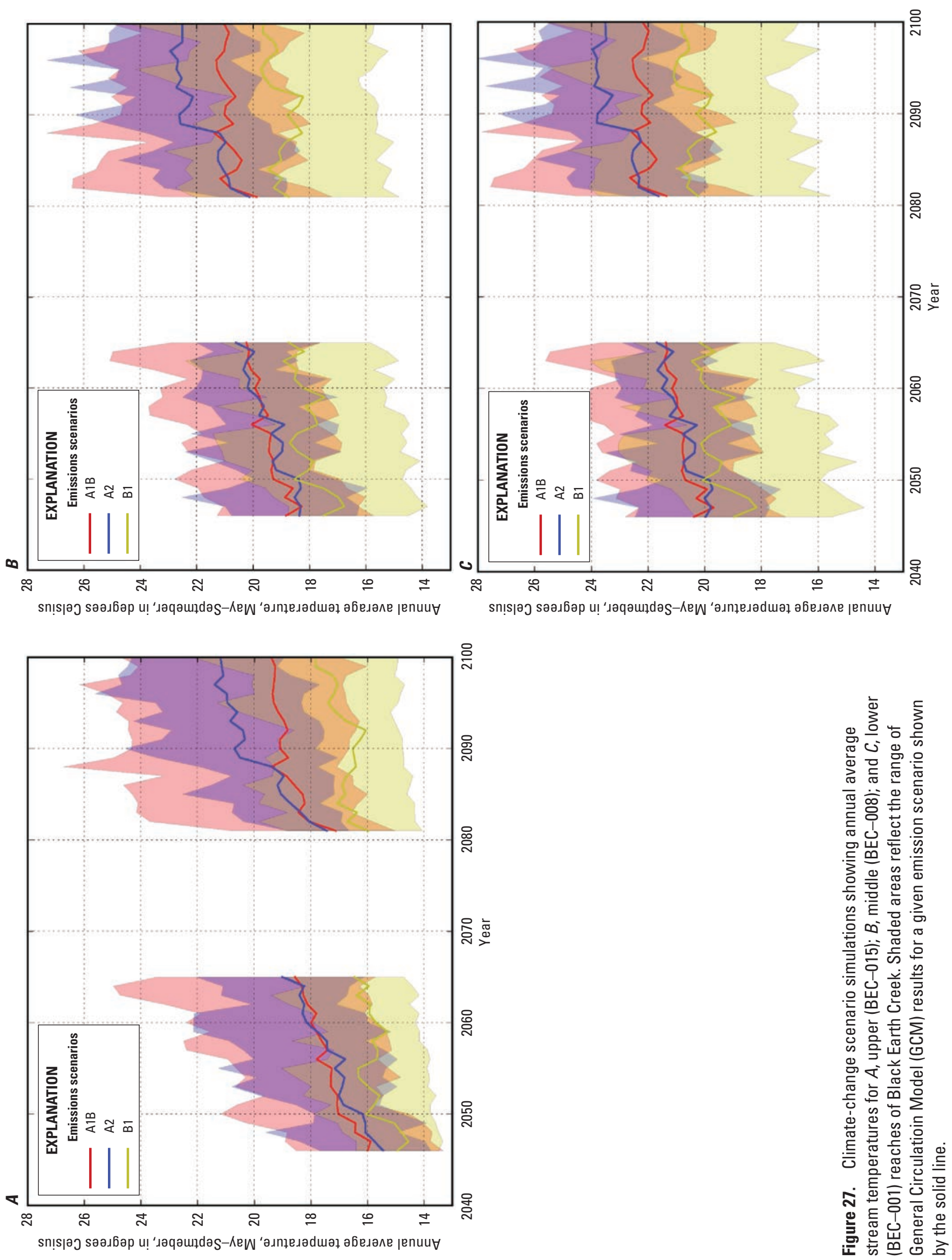
Table 5. Quantile estimation of daily mean stream temperature with associated color-coded tolerance of brown trout (Salmo trutta) for two simulation periods and three emission scenarios at reaches BEC-015, BEC-008, and BEC-001 of Black Earth Creek compared to measured values.

[Values represent only the months of May through September for simulation periods of 2060-65 and 2095-2100, and measured periods of 2005 and 2010-13. $\%$, percent; >, greater than; ${ }^{\circ} \mathrm{C}$, degrees Celsius; $\leq$, less than or equal to]

\begin{tabular}{|c|c|c|c|c|c|c|c|}
\hline \multicolumn{8}{|c|}{ Upper stream reach BEC-015 } \\
\hline \multirow[b]{2}{*}{ Percentile } & \multirow{2}{*}{$\begin{array}{l}\text { 2010-2013 } \\
\text { Measured }\end{array}$} & \multicolumn{3}{|c|}{ 2060-2065 } & \multicolumn{3}{|c|}{ 2095-2100 } \\
\hline & & B1 & A1B & A2 & B1 & A1B & $\mathbf{A 2}$ \\
\hline $90 \%$ & 16.4 & 18.0 & 20.5 & 21.0 & 19.9 & 21.5 & 24.1 \\
\hline $75 \%$ & 15.4 & 17.3 & 19.8 & 20.1 & 18.8 & 20.9 & 22.9 \\
\hline $50 \%$ & 14.4 & 16.1 & 18.3 & 18.6 & 17.4 & 19.7 & 21.4 \\
\hline $25 \%$ & 13.1 & 14.8 & 16.8 & 16.8 & 16.1 & 18.0 & 19.4 \\
\hline $10 \%$ & 11.6 & 14.0 & 15.4 & 15.4 & 15.0 & 16.5 & 17.7 \\
\hline $5 \%$ & 10.7 & 13.6 & 14.8 & 14.6 & 14.5 & 15.9 & 17.1 \\
\hline
\end{tabular}

\section{EXPLANATION}

Lethal $\left(>22^{\circ} \mathrm{C}\right)$

Critical $\left(18-22^{\circ} \mathrm{C}\right)$

Optimal $\left(\leq 18^{\circ} \mathrm{C}\right)$

\begin{tabular}{|c|c|c|c|c|c|c|c|}
\hline \multicolumn{8}{|c|}{ Intermediate stream reach BEC-008 } \\
\hline \multirow[b]{2}{*}{ Percentile } & \multirow{2}{*}{$\begin{array}{l}\text { 2010-2013 } \\
\text { Measured }\end{array}$} & \multicolumn{3}{|c|}{ 2060-2065 } & \multicolumn{3}{|c|}{ 2095-2100 } \\
\hline & & B1 & A1B & A2 & B1 & A1B & A2 \\
\hline $90 \%$ & 18.9 & 21.9 & 23.1 & 24.0 & 22.8 & 24.3 & 26.6 \\
\hline $75 \%$ & 17.5 & 20.9 & 22.5 & 22.8 & 21.7 & 23.4 & 25.3 \\
\hline $50 \%$ & 16.1 & 19.1 & 20.6 & 20.9 & 19.9 & 22.0 & 23.3 \\
\hline $25 \%$ & 14.1 & 16.5 & 18.2 & 18.3 & 17.6 & 19.1 & 20.5 \\
\hline $10 \%$ & 12.3 & 14.8 & 15.7 & 15.8 & 15.5 & 17.0 & 18.1 \\
\hline $5 \%$ & 11.5 & 13.9 & 14.7 & 14.3 & 14.7 & 16.1 & 17.4 \\
\hline
\end{tabular}

\begin{tabular}{|c|c|c|c|c|c|c|c|}
\hline \multicolumn{8}{|c|}{ Lower stream reach BEC-001 } \\
\hline \multirow[b]{2}{*}{ Percentile } & \multirow{2}{*}{$\begin{array}{c}2005 \\
\text { Measured }\end{array}$} & \multicolumn{3}{|c|}{ 2060-2065 } & \multicolumn{3}{|c|}{ 2095-2100 } \\
\hline & & B1 & A1B & $\mathbf{A} 2$ & B1 & A1B & $\mathbf{A 2}$ \\
\hline $90 \%$ & 23.1 & 24.2 & 24.9 & 25.6 & 24.6 & 25.7 & 27.7 \\
\hline $75 \%$ & 21.6 & 22.9 & 24.1 & 24.4 & 23.5 & 24.8 & 26.4 \\
\hline $50 \%$ & 19.7 & 20.6 & 21.8 & 22.1 & 21.1 & 23.0 & 24.3 \\
\hline $25 \%$ & 17.6 & 17.6 & 19.0 & 18.8 & 18.5 & 20.0 & 21.3 \\
\hline $10 \%$ & 15.1 & 15.4 & 16.2 & 16.3 & 16.2 & 17.4 & 18.5 \\
\hline $5 \%$ & 14.0 & 14.2 & 15.2 & 14.6 & 15.1 & 16.4 & 17.5 \\
\hline
\end{tabular}




\section{Example of Mitigation of Climate Effects with Land Use Change}

The climate-change scenarios presented previously assumed that the land use retained the same composition and distribution as the calibration period. Although characterizing future land use is outside the scope of this work, here we present a simple example showing how changes to future land use can be used to offset watershed drying that may occur with future climate. In this example, all input for the fully coupled model remained fixed with the exception of the preferential flow density. All calibrated values were increased by a factor of four over the watershed to reflect enhanced infiltration that could result from reducing soil compaction (for example, subsoiling; U.S. Forest Service, 2008) and increasing the number of low-impact development practices such as rain gardens, grass swales, and infiltration galleries. With enhanced infiltration, less water is available for runoff and, as a result, groundwater recharge increases. Changing this one model input resulted in modest mitigation of potential climate effects at the downstream locations of the BEC watershed (for example, about a 10-percent higher flow with enhanced infiltration than the base case climate scenario simulation at Village of Black Earth location shown in figures 22-24); however, the headwater streams within and adjoining the BEC watershed showed larger mitigation, and in some cases enhanced infiltration appears to offset the effects of climate change (fig. 28). This example demonstrates the power of the fully coupled model to explore not only the watershed response to stress but also effectiveness of potential mitigation strategies.

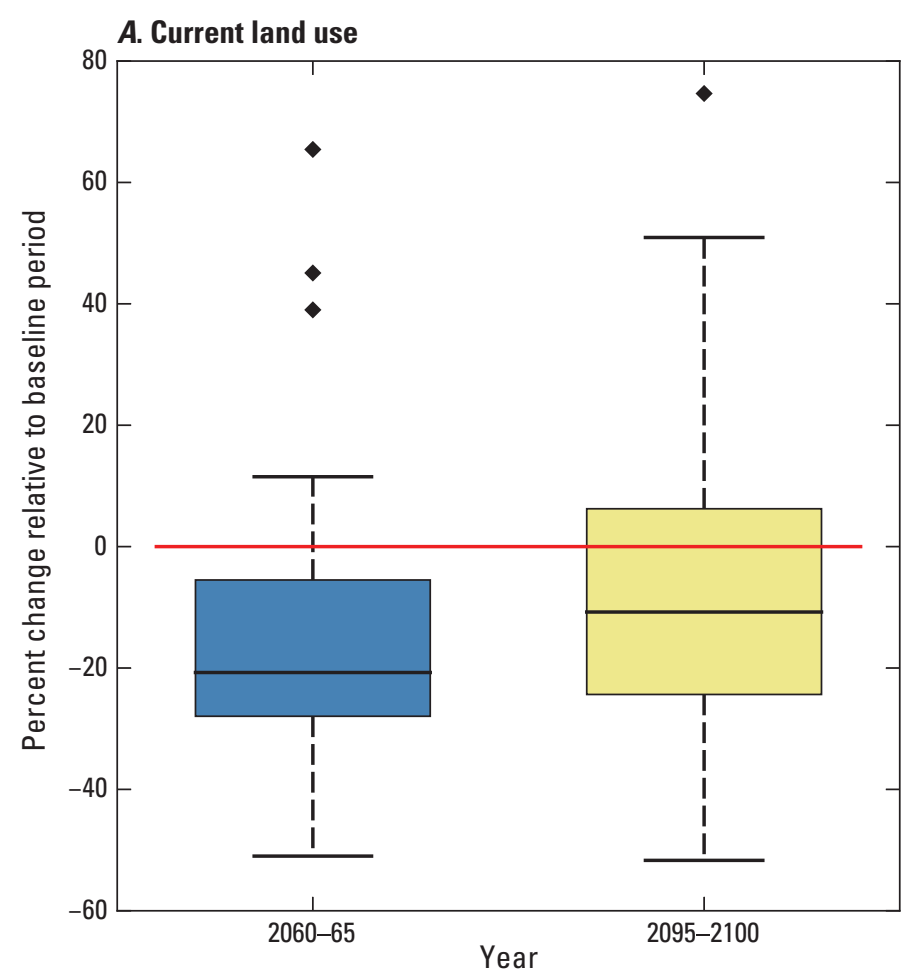

\section{$B$. Enhanced infiltration}

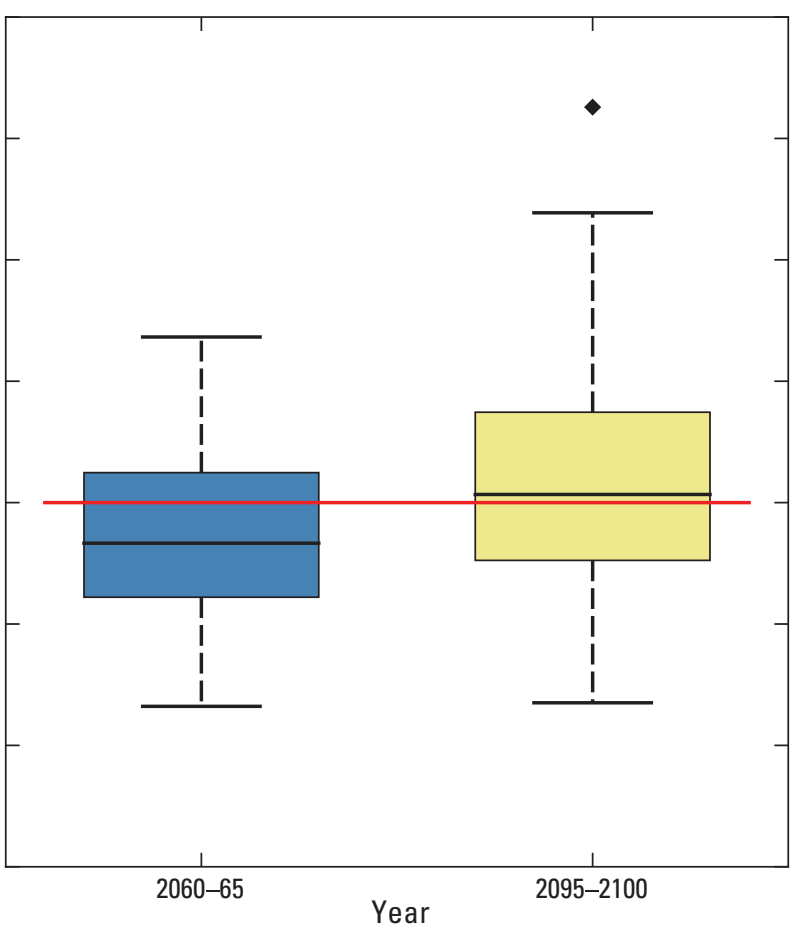

EXPLANATION
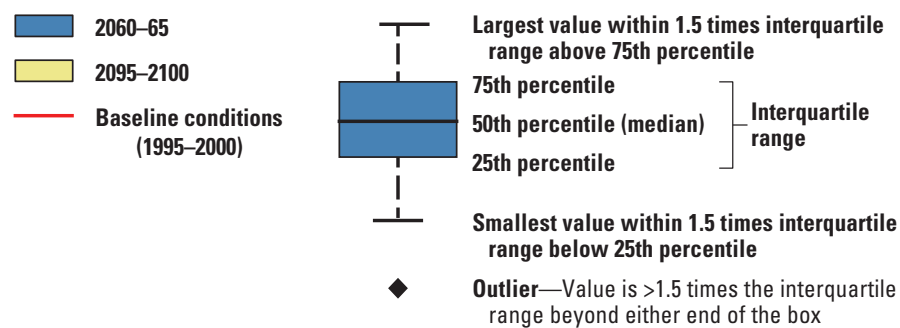

Figure 28. Example of land use change mitigating potential future climate change. The boxplots show climate-change simulations of annual average streamflow in a Black Earth Creek tributary (Brewery Creek) headwater location for two General Circulation Model reported future periods (2060-65 and 2095-2100). The boxplots depict $A$, a scenario where land use is the same as current conditions, and $B$, a simulation where future land use is modified to increase infiltration. 


\section{GSFLOW and SNTEMP Limitations and Assumptions}

Potential limitations of GCM-derived climate change forecasts are well recognized (Intergovernmental Panel on Climate Change, 2007) and thus are noted here but not expounded upon. Climate drivers used for the climate-change scenarios varied appreciably depending on the GCM and emission scenario selected; this uncertainty was reflected in hydrologic-flow and temperature model results. Moreover, the scenarios presented here did not include different potential land use or potential mitigation approaches such as enhanced rain garden density. Therefore, as with all forecasts of this type, the results are best considered to approximate potential outcomes of climate change.

Similar to all models, the BEC hydrologic and temperature process-based models described here are simplifications of the natural world, with corresponding limitations in model simulation capability and forecast suitability. For example, the SNTEMP model assumes homogeneous and instantaneous mixing when multiple sources of water are combined. Similarly, the MODFLOW model cell size is 328 feet $\times 328$ feet ( 100 meters $\times 100$ meters); discretization of the PRMS surface-water model (HRU) is even coarser. The conditions within the grid division (groundwater level, groundwater flow, evapotranspiration rate, soil moisture) are thus reduced to one average value for the entire model cell or HRU; therefore, even though the resolution of parts of the model grid is relatively high, the model would not be suitable as an unmodified starting point for many site-scale or local headwater problems or issues without additional refinement.

Likewise, temporal simplifications were needed to develop tractable models used for this work. Models were constructed using daily or larger time increments; thus, partialday ("continuous" or "storm-mode") simulations of individual storm events were not in the scope of this work. Actual flood peaks that occur in the watershed due to intense rainfall on the partial-day timescale will not be reflected by this modeling on the daily or larger time steps. Because of this averaging of partial-day stresses in the model, and the fact that the tool is developed by using watershed flows and not local hydraulic characteristics at any one location in the watershed, model results are reported in streamflow (discharge) and not local stream stage or flood peak. In addition, forecasts of future response assume an unchanging land use and vegetation composition-assumptions that likely do not represent future conditions optimally.

Although hydrologic parameters and aquifer and confining unit geometry in parts of the model area are generally not well known at smaller scales, data are more abundant and of better quality in some areas of the model domain. As a result, properties that provide the best match between measured and simulated flows and groundwater levels primarily reflect conditions in these more data-rich parts of the watershed. Moreover, not all observed targets were given equal weight in the calibration; thus, all targets are not comparably simulated (appendix 6). Therefore, the ability of the GSFLOW model to simulate the Black Earth Creek system is variable, where some features (for example, Black Earth Creek streamflow at the Village of Black Earth) are better represented than others (for example, Halfway Prairie Creek). As constructed and calibrated, the hydrologic model is best suited to simulate large-scale bulk properties of the hydrologic system instead of smaller-scale property variation. The seasonal variability of solar radiation and potential evapotranspiration was based on existing national datasets; more contemporaneous local datasets would improve these crucial variables that influence many of the hydrologic processes in the model. Finally, the models are currently limited in their ability to simulate frozen-ground conditions; therefore, simulated results may not capture all the short-term dynamics of the natural system during snowmelt periods.

Several assumptions and limitations are associated with instream temperature modeling. Perhaps most notably, SNTEMP is a successive steady-state model and therefore can only represent changes during the minimum averaging period - in this case, 1 day. In other words, because the minimum averaging period is 1 day, the model cannot discern changes to stream temperature that occurred on a subdaily scale. Consequently, changes in streamflow temperature cannot be well represented unless the change is gradually varying and sustained beyond the minimum averaging period. Another limiting assumption in SNTEMP is homogenous and instantaneous mixing wherever two sources of water are combined; no dispersion or diffusion is represented in the model. Finally, all boundary conditions are considered homogeneous and constant. This assumption has implications for the size of the network simulated for a single averaging period. Because the model is steady state, the water and associated thermal load must enter and exit within the 1-day averaging period. Given the relatively small geographical scale of tributaries to Black Earth Creek and the velocity of the stream at base flow conditions, the assumption of daily traveltime was likely violated only occasionally in this model. Nevertheless, potential for violations to this assumption may be important for some forecasts, such as reach-scale heat transport.

\section{Summary}

Separately constructed/calibrated transient surface-water and steady-state groundwater models were used to construct a single coupled transient groundwater/surface-water model for the Black Earth Creek watershed in south-central Wisconsin. The computer code GSFLOW was used to simulate the coupled hydrologic system; GSFLOW iteratively uses formulations of the Precipitation Runoff Modeling System (PRMS) surface-water model for hydrologic processes in the atmosphere, at land surface, and within the soil zone, and a MODFLOW groundwater model for unsaturated-zone, 
saturated-zone, and stream simulation. The coupled model was calibrated by using heads, streamflows, solar radiation, and snowpack measurements collected during water years 2000-7 (October 1, 1999 through September 30, 2007); calibration was done by use of advanced features in the PEST parameterestimation software suite. Simulated streamflows from the calibrated GSFLOW model and other basin characteristics were used for SNTEMP stream-temperature simulations for selected tributaries in the Black Earth Creek watershed. The SNTEMP model was calibrated to high-resolution stream temperature time-series data measured in 2005. The calibrated GSFLOW and SNTEMP models were then used to simulate effects of potential climate change for 2010 to 2100. An ensemble of climate models and emission scenarios were evaluated. The results of this study can be summarized as follows:

- Separate calibration of the uncoupled groundwater and surface-water models provided a representative initial parameter set for coupled model calibration.

- Daily stream temperatures measured during 2005 were successfully simulated by using a 1-dimensional, steady-state SNTEMP stream-temperature model; the model fit was acceptable for the range of groundwater inflow rates into the streams.

- Downscaled climate drivers for 2010-2100 showed increases in maximum and minimum air temperature during the scenario period. Scenarios of future precipitation did not show a monotonic trend like temperature. Uncertainty in the climate drivers increased over time for both temperature and precipitation.

- During the scenario period, growing-season length was simulated to increase by weeks, and potential and actual evapotranspiration rates were simulated to increase appreciably in response to increasing air temperature and longer growing season. Simulated actual evapotranspiration rates increased less than simulated potential evapotranspiration rates as a result of water limitation in the root zone during the summer highevapotranspiration period.

- The hydrologic-system response to climate change was characterized by a general reduction in recharge, streamflow, and seasonal dynamics. The reduction in dynamics reflects a diminished importance of the snowmelt pulse and, to a lesser extent, an increase in the importance of winter groundwater recharge.

- Stream temperatures are expected to increase with climate change. The estimated increase in annual average temperature ranged from approximately 3 to 6 degrees Celsius $\left({ }^{\circ} \mathrm{C}\right)$ by 2100 in upper, high-groundwaterinflow reaches of Black Earth Creek and 2 to $4{ }^{\circ} \mathrm{C}$ in the downstream reaches with less groundwater inflow.
- The climate drivers used for the climate change scenarios varied appreciably between the General Circulation Model and emission scenario selected; this uncertainty was reflected in hydrologic-flow and temperature model results. Thus, as with all forecasts of this type, the results are best considered one set of potential approximations of future climate change.

- Although not extensively tested, a simple simulation of land use change occurring concurrently with potential climate change demonstrated that some adverse effects can be mitigated with local actions. This result suggests that watershed-scale societal actions can offset adverse effects of larger climatic drivers of the system.

\section{Selected References}

Anderson, K.M., 2002, Hydrogeologic controls on flow to Frederick Springs in the Pheasant Branch Watershed, Middleton, Wisconsin: University of Wisconsin-Madison, $172 \mathrm{p}$.

Anderson, M.P., Woessner, W.W., and Hunt, R.J., 2015, Applied groundwater modeling - Simulation of flow and advective transport (2nd ed.): Academic Press, Inc., 564 p. [ISBN 9780120581030.]

Arcement, G.J., and Schneider, V.R., 1989, Guide for selecting Manning's roughness coefficients for natural channels and flood plains: U.S. Geological Survey Water-Supply Paper 2339, 67 p. [Also available at: http://pubs.usgs.gov/ wsp/2339/report.pdf.]

Bartholow, J.M., 1989, Stream temperature investigationsField and analytical methods: U.S. Fish and Wildlife Service Instream Flow Information Paper No. 13, Biological Report 89(17), 139 p.

Bartholow, J.M., 1991, A modeling assessment of the thermal regime for an urban sport fishery: Environmental Management, v. 15, no. 6, p. 833-845.

Bell, J.M., 2006, The assessment of thermal impacts on habitat selection, growth, reproduction, and mortality in brown trout (Salmo trutta L) - A review of the literature. Applied Ecological Services, AES Project 05-0206, 23 p.

Beven, K. and Binley, A., 1992, The future of distributed models: Model calibration and uncertainty prediction. Hydrol. Process., 6: 279-298, doi: 10.1002/hyp.3360060305.

Beven, K.J., and Freer, J., 2001, Equifinality, data assimilation, and uncertainty estimation in mechanistic modelling of complex environmental systems using the GLUE methodology: Journal of Hydrology, v. 249, no. 1-4, p. 11-29. 
Bradbury, K.R., Swanson, S.K., Krohelski, J.T., and Fritz, A.K., 1999, Hydrogeology of Dane County, Wisconsin: Madison, Wis., Wisconsin Geological and Natural History Survey, Open-File Report 1999-04, 66 p.

Brown, B.A., Peters, R.M., and Massie-Ferch, K., 2013, Preliminary bedrock geology of Dane County, Wisconsin: Wisconsin Geological and Natural History Survey Plate WOFR2013-01-plate01, 1 p.

Busby, M.W., 1963, Surface water, in Cline, D.R., Hydrology of Upper Black Earth Creek Basin Wisconsin: Geological Survey Water-Supply Paper 1669-C, p. 18-20.

Christiansen, D.E., Markstrom, S.L., and Hay, L.E., 2011, Impacts of climate change on growing season in the United States: Earth Interactions, v. 15, no. 33, p. 1-17.

Clayton, L., and Attig, J.W., 1997, Pleistocene geology of Dane County, Wisconsin. Wisconsin Geological and Natural History Survey Bulletin 95, 64 p.

Cline, D.Z., and Busby, M.W., 1963, Hydrology of Upper Black Earth Creek Basin Wisconsin: U.S. Geological Survey Water-Supply Paper 1669-C, 27 p.

Dane County Land Information Office and Fly Dane Partnership, 2001, Dane County (WI) 2000 two-foot vertical digital elevation model: Madison, Wis., Dane County Land Information Office.

Dane County Land Information Office, 2002, The 2000 digital land use inventory development procedures for Dane County, Wisconsin: Madison, Wis., Dane County Land Information Office.

Doherty, John, 2014a, PEST, Model-independent parameter estimation-User manual (5th ed., with slight additions): Brisbane, Australia, Watermark Numerical Computing.

Doherty, John, 2014b, Addendum to the PEST manual: Brisbane, Australia, Watermark Numerical Computing.

Doherty, John, and Hunt, R.J., 2009, Two statistics for evaluating parameter identifiability and error reduction: Journal of Hydrology, v. 366, p. 119-127, doi: 10.1016/j. jhydrol.2008.12.018.

Doherty, J.E., and Hunt, R.J., 2010, Approaches to highly parameterized inversion-A guide to using PEST for groundwater-model calibration. U.S. Geological Survey Scientific Investigations Report 2010-5169, 60 p. [Also available at http://pubs.usgs.gov/sir/2010/5169/.]

Dripps, W.R., 2003, The spatial and temporal variability of ground water recharge: University of Wisconsin-Madison, Department of Geology and Geophysics, Ph.D. dissertation, 231 p.
Dunne, T., and Black, R.D., 1970, An experimental investigation of runoff production in permeable soils: Water Resources Research, v. 6, no. 5, p. 1296-1311.

Field, S.J., and Graczyk, D.J., 1990, Hydrology, aquatic macrophytes, and water quality of Black Earth Creek, and its tributaries, Dane County, Wisconsin, 1985-86: U.S. Geological Survey Water-Resources Investigations Report 89-4089, 38 p. [Also available at http://pubs.usgs. gov/wri/1989/4089/report.pdf.]

Gebert, W.A., Walker, J.F., and Hunt, R.J., 2011, Groundwater recharge in Wisconsin-Annual estimates for 1970-99 using streamflow data: U.S. Geological Survey Fact Sheet 2009-3092, 4 p. [Also available at http://pubs.usgs.gov/ fs/2009/3092/pdf/FS2009_3092.pdf.]

Graczyk, D.J., Walker, J.F., Horwatich, J.A., and Bannerman, R.T., 2003, Effects of best-management practices in the Black Earth Creek priority watershed, Wisconsin, 1984-98: U.S. Geological Survey Water-Resources Investigations Report 03-4163, 24 p. [Also available at http://pubs.usgs. gov/wri/wri034163/pdf/wrir03-4163.pdf.]

Hancock, P.J., Hunt, R.J., and Boulton, A.J., 2009, PrefaceHydrogeoecology, the interdisciplinary study of groundwater dependent ecosystems: Hydrogeology Journal, v. 17, no. 1, p. 1-4, doi:10.1007/s10040-008-0409-8.

Harbaugh, A.W., 2005, MODFLOW-2005, the U.S. Geological Survey modular ground-water model-The groundwater flow process: U.S. Geological Survey Techniques and Methods, book 6, chap. A16 [variously paged]. [Also available at https://pubs.usgs.gov/tm/2005/tm6A16/PDF/ TM6A16.pdf.]

Harter, T., and Hopmans, J.W., 2004, Role of vadose zone flow processes in regional scale hydrology-Review, opportunities and challenges, in Feddes, R.A., de Rooij, G.H., and van Dam, J.C., eds., Unsaturated zone modeling-Progress, applications, and challenges: Dordrecht, Boston, Kluwer Academic, p. 179-208.

Hay, L.E., and Umemoto, M., 2007, Multiple-objective stepwise calibration using Luca: U.S. Geological Survey OpenFile Report 2006-1323, 25 p. [Also available at http://pubs. er.usgs.gov/publication/ofr20061323.]

Horton, R.E., 1933, The role of infiltration in the hydrological cycle: American Geophysical Union Transactions, v. 23, p. 479-482.

Hunt, R.J., Anderson, M.P., and Kelson, V.A., 1998, Improving a complex finite-difference ground water flow model through the use of an analytic element screening model: Ground Water, v. 36, no. 6, p. 1011-1017. 
Hunt, R.J., Bradbury, K.R., and Krohelski, J.T., 2001, The effects of large-scale pumping and diversion on the water resources in Dane County, Wisconsin: U.S. Geological Survey Fact Sheet 127-01, 4 p. [Also available at http://pubs. er.usgs.gov/usgspubs/fs/fs12701.]

Hunt, R.J., Doherty, J., and Tonkin, M.J., 2007, Are models too simple? Arguments for increased parameterization: Ground Water, v. 45, no. 3, p. 254-262, doi:10.1111/j.17456584.2007.00316.x.

Hunt, R.J., Doherty, J., and Walker, J.F., 2009, Parameter estimation and coupled groundwater/surface-water models-A PEST approach, in Conference Proceedings from the 1st PEST Conference, November 1-3, 2009, Potomac, Md.: Raleigh, North Carolina, Lulu Press, Inc.

Hunt, R.J., Feinstein, D.T., Pint, C.D., and Anderson, M.P., 2005, The importance of diverse data types to calibrate a watershed model of the Trout Lake Basin, northern Wisconsin, USA: Journal of Hydrology, v. 321, no. 1-4, p. 286-296. doi:10.1016/j.jhydrol.2005.08.005

Hunt, R.J., Prudic, D.E., Walker, J.F., and Anderson, M.P., 2008, Importance of unsaturated zone flow for simulating recharge in a humid climate: Ground Water, v. 46, no. 4, p. 551-560, doi:10.1111/j.1745-6584.2007.00427.x.

Hunt, R.J., and Steuer, J.J., 2000, Simulation of the recharge area for Frederick Springs, Dane County, Wisconsin: U.S. Geological Survey Water-Resources Investigations Report 00-4172, 33 p. [Also available at http://pubs.usgs. gov/wri/2000/4172/report.pdf.]

Hunt, R.J., and Steuer, J.J., 2001, Evaluating the effects of urbanization and land-use planning using ground-water and surface-water models: U.S. Geological Survey Fact Sheet 102-01, 4 p. [Also available at http://pubs.er.usgs.gov/publication/fs10201].

Hunt, R.J., Strand, Mac, and Walker, J.F., 2006, Measuring groundwater-surface water interaction and its effect on wetland stream benthic productivity, Trout Lake watershed, northern Wisconsin, USA: Journal of Hydrology, v. 320, p. 370-384.

Hunt, R.J., Walker, J.F., Selbig, W.R., Westenbroek, S.M, and Regan, R.S., 2013, Simulation of climate-change effects on streamflow, lake water budgets, and stream temperature using GSFLOW and SNTEMP, Trout Lake watershed, Wisconsin: U.S. Geological Survey Scientific Investigations Report 2013-5159, 118 p. [Also available at http://pubs. usgs.gov/sir/2013/5159/.]
Hunt, R.J., and Wilcox, D.A., 2003, Ecohydrology-Why hydrologists should care: Ground Water, v. 41, no. 3, p. 289, doi:10.1111/j.1745-6584.2003.tb02592.x.

Intergovernmental Panel on Climate Change, 2007, Summary for policymakers, in Climate change 2007-The physical science basis, Contributions of Working Group 1 to the Fourth Assessment Report of the Intergovernmental Panel on Climate Change: Cambridge and New York, Cambridge University Press, 18 p.

Jonsson, B., and Jonsson, N., 2009, A review of the likely effects of climate change on anadromous Atlantic salmon Salmo salar and brown trout Salmo trutta, with particular reference to water temperature and flow: Journal of Fish Biology, v. 75, p. 2381-2447.

Krohelski, J.T., Bradbury, K.R., Hunt, R.J., and Swanson, S.K., 2000, Numerical simulation of ground-water flow in Dane County, Wisconsin: Wisconsin Geological and Natural History Survey Bulletin, v. 98, 31 p.

Krohelski, J.T., Lin, Y., Rose, W.J., and Hunt, R.J., 2002, Simulation of Fish, Mud, and Crystal Lakes and the shallow ground-water system, Dane County, Wisconsin: U.S. Geological Survey Water-Resources Investigations Report 02-20, 18 p. [Also available at http://pubs.usgs.gov/ wri/2002/4014/report.pdf.]

Krug, W.R., and Goddard, G.L., 1986, Effects of urbanization on streamflow, sediment loads, and channel morphology in Pheasant Branch Basin near Middleton, Wisconsin: U.S. Geological Survey Water-Resources Investigations Report 85-4068, 82 p.

Leavesley, G.H., Lichty, R.W., Troutman, B.M., and Saindon, L.G., 1983, Precipitation-runoff modeling system-User's manual: U.S. Geological Survey Water-Resources Investigations Report 83-4238, 207 p. [Also available at http:// pubs.usgs.gov/wri/1983/4238/report.pdf.]

Leavesley, G.H., Markstrom, S.L., Viger, R.J., and Hay, L.E., 2005, USGS Modular Modeling System (MMS) Precipitation-Runoff Modeling System (PRMS) MMSPRMS, in Singh, V., and Frevert, D., eds., Watershed models: Boca Raton, Fla., CRC Press, p. 159-177.

Leopold, L.B., 1974, Water-A primer: San Francisco, W.H. Freeman Co., 172 p.

Maher, L.J., 1999, The early history of the Pheasant Branch watershed-Appendix 3: Report from the North Fork Pheasant Branch Watershed Committee, accessed January 5, 2016, at http://www.geology.wisc.edu/ maher/pheasant_ branch.html. 
Markstrom, S.L., Hay, L.E., Ward-Garrison, D.C., Risley, J.C., Battaglin, W.A., Bjerkle, D.M., Chase, K.J., Christiansen, D.E., Dudley, R.W., Hunt, R.J., Koczot, K.M., Mastin, M.C., Regan, R.S., Viger, R.L., Vining, K.C., and Walker, J.F., 2012, Integrated watershed scale response to climate change for selected basins across the United States: U.S. Geological Survey Scientific Investigations Report 2011-5077, 134 p. [Also available at http://pubs.usgs.gov/ sir/2011/5077/.]

Markstrom, S.L., Niswonger, R.G., Regan, R.S., Prudic, D.E., and Barlow, P.M., 2008, GSFLOW-Coupled GroundWater and Surface-Water Flow Model based on the integration of the Precipitation-Runoff Modeling System (PRMS) and the Modular Ground-Water Flow Model (MODFLOW-2005): U.S. Geological Survey Techniques and Methods, book 6, chap. D1, 240 p. [Also available at http:// pubs.usgs.gov/tm/tm6d1/.]

Markstrom, S.L., Regan, R.S., Hay, L.E., Viger, R.J., Webb, R.M.T., Payn, R.A., and LaFontaine, J.H., 2015, PRMSIV, the Precipitation-Runoff Modeling System, Version 4: U.S. Geological Survey Techniques and Methods, book 6, chap. B7, 158 p. [Also available at http://pubs.er.usgs.gov/ publication/tm6B7.]

McGrath, R.W., 1991, Investigation of atrazine contamination in bedrock aquifers, Western Dane County, Wisconsin: Department of Geology and Geophysics, University of Wisconsin-Madison, M.S. thesis, 218 p.

Niswonger, R.G., Panday, Sorab, and Ibaraki, Motomu, 2011, MODFLOW-NWT, A Newton formulation for MODFLOW-2005: U.S. Geological Survey Techniques and Methods, book 6, chap. A37, 44 p. [Also available at http:// pubs.usgs.gov/tm/tm6a37/pdf/tm6a37.pdf.]

Niswonger, R.G., and Prudic, D.E., 2005, Documentation of the Streamflow-Routing (SFR2) Package to include unsaturated flow beneath streams-A modification to SFR1: U.S. Geological Survey Techniques and Methods, book 6, chap. A13, 51 p. [Also available at https://pubs.usgs.gov/ tm/2006/tm6A13/pdf/tm6a13.pdf.]

Niswonger, R.G., Prudic, D.E., and Regan, R.S., 2006, Documentation of the Unsaturated-Zone Flow (UZF1) Package for modeling unsaturated flow between the land surface and the water table with MODFLOW-2005: U.S. Geological Survey Techniques and Methods, book 6, chap. A19, 74 p. [Also available at https://pubs.usgs.gov/tm/2006/tm6a19/ pdf/tm6a19.pdf.]

Novitzki, R.P., 1973, Improvement of trout streams in Wisconsin by augmenting low flows with ground water: U.S. Geological Survey Water-Supply Paper 2017, 52 p., [Also available http://pubs.er.usgs.gov/publication/wsp2017].
Parsen, M.J., Bradbury, K.R., Hunt, R.J., and Feinstein, D.T., 2016, The 2016 groundwater flow model for Dane County, Wisconsin: Wisconsin Geological and Natural History Survey Bulletin 110, 56 p.

R Core Team, 2015, R: A language and environment for statistical computing. R Foundation for Statistical Computing, Vienna, Austria, accessed 17 May 2016 at http://www.Rproject.org/.

Steuer, J.J., and Hunt, R.J., 2001, Use of a watershed-modeling approach to assess hydrologic effects of urbanization, North Fork Pheasant Branch Basin near Middleton, Wisconsin: U.S. Geological Survey Water-Resources Investigations Report 01-4113, 49 p. [Also available at https://pubs. er.usgs.gov/publication/wri014113.]

Swanson, S.K., 1996, A comparison of two methods for estimating groundwater recharge in Dane County, Wisconsin: Department of Geology and Geophysics, University of Wisconsin-Madison, M.S. thesis, 123 p.

Swanson, S.K., 2001, Hydrologic controls on spring flow near Madison, Wisconsin: Department of Geology and Geophysics, University of Wisconsin-Madison, Ph.D. thesis, 436 p.

Theurer, F.D., Voos, K.A., and Miller, W.J., 1984, Instream water temperature model: U.S. Fish and Wildlife Service Instream Flow Information Paper 16, FWS/OBS-85/15 [variously paged].

U.S. Forest Service, 2008, Using subsoiling to reduce soil compaction: U.S. Forest Service Report 0834-2828-MTDC, 15 p., accessed 15 February 2016, at http://www.fs.fed.us/td/pubs/pdfpubs/pdf08342828/pdf08342828dpi72.pdf.

U.S. Geological Survey, 2004a, National elevation dataset: accessed July 29, 2004, at http://gisdata.usgs.gov.

U.S. Geological Survey, 2004b, U.S. Geological Survey topographic maps: accessed July 29, 2004, at http://topomaps. usgs.gov/index.html.

U.S. Army Corps of Engineers, 1998, Runoff from snowmelt: Engineer Manual 1110-2-1406, $142 \mathrm{p}$.

UW Land Information and Computer Graphics Facility (LICGF), 1988, Dane County digital soils.

Viger, R.J., and Leavesley, G.H., 2007, The GIS Weasel user's manual: U.S. Geological Survey Techniques and Methods, book 6, chap. B4, 201 p. [Also available at http://pubs.usgs. gov/tm/2007/06B04/.]

Ward, D.S., Buss, D.R., Mercer, J.W., and Hughes, S.S., 1987, Evaluation of a groundwater corrective action at the ChemDyne hazardous waste site using a telescopic mesh refinement modeling approach: Water Resources Research, v. 23, no. 4, p. 603-617. 
Weiss, M., and Menzel, L., 2008, A global comparison of four potential evapotranspiration equations and their relevance to stream flow modelling in semi-arid environments: Advances in Geosciences, v. 18, p. 15-23.

Westenbroek, S.M., Doherty, J.E., Walker, J.F., Kelson, V.A., Hunt, R.J., and Cera, T.B., 2012, Approaches in highly parameterized inversion-TSPROC, A general time-series processor to assist in model calibration and result summarization: U.S. Geological Survey Techniques and Methods, book 7, chap. C7, 73 p. [Also available at http://pubs.usgs. gov/tm/tm7c7/.]

Westenbroek, S.M., Kelson, V.A., Dripps, W.R., Hunt, R.J., and Bradbury, K.R., 2010, SWB-A modified Thornthwaite-Mather Soil Water Balance code for estimating groundwater recharge. U.S. Geological Survey Techniques and Methods, book 6, chap. A31, 60 p. [Also available at http://pubs.usgs.gov/tm/tm6-a31/.]

Wisconsin Department of Natural Resources, 1998, GEODISC 2.1, Wisconsin Department of Natural Resources Geographic Services Section, May 1998.

Winter, T.C., Harvey, J.W., Franke, O.L., and Alley, W.M., 1998, Ground water and surface water-A single resource: U.S. Geological Survey Circular 1139, 79 p. [Also available at http://pubs.usgs.gov/circ/circ1139/.]

Winter, T.C., Rosenberry, D.O., and LaBaugh, J.W., 2003, Where does the ground water in small watersheds come from?: Ground Water, v. 41, no. 7, p. 989-1000, doi: 10.1111/j.1745-6584.2003.tb02440.x.

Wisconsin Initiative on Climate Change Impacts, 2011, Wisconsin's changing climate-Impacts and adaptation: Madison, Wis., Nelson Institute for Environmental Studies, University of Wisconsin-Madison and the Wisconsin Department of Natural Resources, 217 p. 

Appendixes 


\section{Appendix 1. Black Earth Creek Groundwater Model Construction and Calibration}

\section{Groundwater-Model Construction}

Groundwater flow within the Black Earth Creek watershed was simulated by using MODFLOW-2005 (Harbaugh, 2005), which uses a finite-difference scheme to solve the groundwater flow equation. The model was run both in steady state for uncoupled calibration, and in sequential steady state and daily time-step transient mode for fully coupled calibration. The watershed has been included within the domains of several regional modeling studies (McLeod 1975a, 1975b; Krohelski and others, 2000) that represent stages in the development and refinement of a countywide groundwater model. The initial model framework and boundary conditions (figs. 1-1 and 1-2) were taken from Dane County Regional Model (DCRM) documented by Krohelski and others (2000); the DCRM conceptualization was refined using work by Anderson (2002) and Swanson (2001) in nearby areas of Dane County. Calibration targets (heads, fluxes) included those used by Krohelski and others (2000) and additional calibration targets that were collected during this study (appendix 5). The groundwater-model construction methods followed those described by Hunt and Steuer (2000) and Hunt and others (2001) for the adjacent eastern Pheasant Branch watershed. The methods included a telescopic mesh refinement of a regional MODFLOW groundwater-flow model and automated calibration using a parameter-estimation program. The original DCRM grid spacing was 1,312.4 feet on a side; the refined grid is one-fourth of the spacing, or 328.1 feet (100 meters) on a side. Thus, every county-scale model node is represented by 16 nodes in the telescopic mesh refinement model.

The three-dimensional, finite-difference model employs a grid consisting of 316 rows and 340 columns with a uniform horizontal cell size of $328.1 \times 328.1$ feet $(100 \times 100$ meters $)$ and six layers, which results in a model domain of 218 square miles (56,514 hectares). The three-dimensional model grid had perimeter boundaries extracted from the existing DCRM using the telescopic-mesh approach of Ward and others (1987). Briefly, groundwater fluxes applied at the boundaries of the six-layer Black Earth Creek watershed MODFLOW grid were extracted from the three-layer DCRM; the three-layer fluxes were distributed to the six layers on the basis of layer transmissivity and supplied to the model domain by using the MODFLOW Well Package. Similarly, high capacity pumping from the DCRM was distributed to the six layers on the basis of layer-transmissivity and input with the MODFLOW Well Package. DCRM pumping rates were updated when new rates were available. The crystalline bedrock, assumed to be impervious, forms the bottom boundary of the model (figs. 1-2 and $1-3)$. Recharge flux is specified across the water table, which forms the upper boundary of the groundwater model.

Similar to Krohelski and others (2000), the aquifer was represented in the model by using the stratigraphic conceptualization of the Pleistocene sediments (fig. 1-2) by Clayton and Attig (1997), the bedrock (fig. 1-2) of Brown and others (2013), and the hydrogeologic framework of Bradbury and others (1999). Unconsolidated deposits (sand and gravel aquifer, layer 1) and the Upper Bedrock aquifer (layer 2) were also refined (fig. 1-3) following the Pleistocene geology of Dane County (Clayton and Attig, 1997). Hydraulic conductivity within the model domain was specified by using a combination of (1) piecewise-constant zones and (2) pilot points (Doherty, 2003; Doherty and others, 2010). This specification resulted in 379 adjustable parameters that provided a highly parameterized model requiring regularized inversion (Hunt and others, 2007) to calibrate. In the pilot-point approach, parameter values are estimated at a number of discrete locations distributed throughout the model domain; cell-by-cell parameterization then takes place through spatial interpolation from the pilot points to the model grid (or mesh). Zones were used for subglacial deposits and most bedrock units where the piecewise-constant assumption was not likely to be violated. Pilot points were used to represent geologic variability where it was believed to exist (fig. 1-4). Parameters represented by pilot points included (1) the horizontal $\left(\mathrm{K}_{\mathrm{h}}\right)$ and vertical $\left(\mathrm{K}_{\mathrm{v}}\right)$ hydraulic conductivity for the incised glacio-fluvial sediments and (2) $\mathrm{K}_{\mathrm{v}}$ for the Eau Claire shale confining unit (layer 5, fig. 1-2). In the glacio-fluvial sediments, vertical-anisotropy pilot points were co-located at each Kh pilot-point location. Additional discussion of the application of pilot points is given in appendix 3 and the calibrated values of hydraulic conductivity resulting from the pilot-point distribution are given in appendix 6.

All streams used the MODFLOW Streamflow Routing (SFR2) Package (Niswonger and Prudic, 2005) to allow accounting of streamflow. The SFR2 Package also limits the amount of water a stream can lose to the adjacent aquifer to the amount of water flowing in the stream. Streambed sediments are assumed to have a uniform thickness of 1 foot and a uniform vertical hydraulic conductivity, which is estimated during calibration. Lake Mendota, located outside of the Black Earth Creek watershed, was simulated by using the MODFLOW General Head Boundary (GHB) Package (fig. 1-1).

The areal distribution of recharge was calculated using the Soil-Water Balance (SWB) approach; the SWB approach and recharge array used in the Black Earth Creek watershed groundwater model (fig. 1-5) is described in detail in Westenbroek and others (2010). Recharge was specified to the MODFLOW model using the Unsaturated-Zone Flow (UZF) Package (Niswonger and others, 2006). Water leaving the soil zone (calculated by the SWB model) was specified as "infiltration" to the top of the unsaturated zone. Recharge to the saturated zone was calculated by the UZF Package using specified unsaturated-zone properties, including the vertical saturated hydraulic conductivity of the soil (input variable VKS) and a parameter that describes the relation of hydraulic conductivity to soil moisture (a Brooks-Corey epsilon or EPS variable), as 


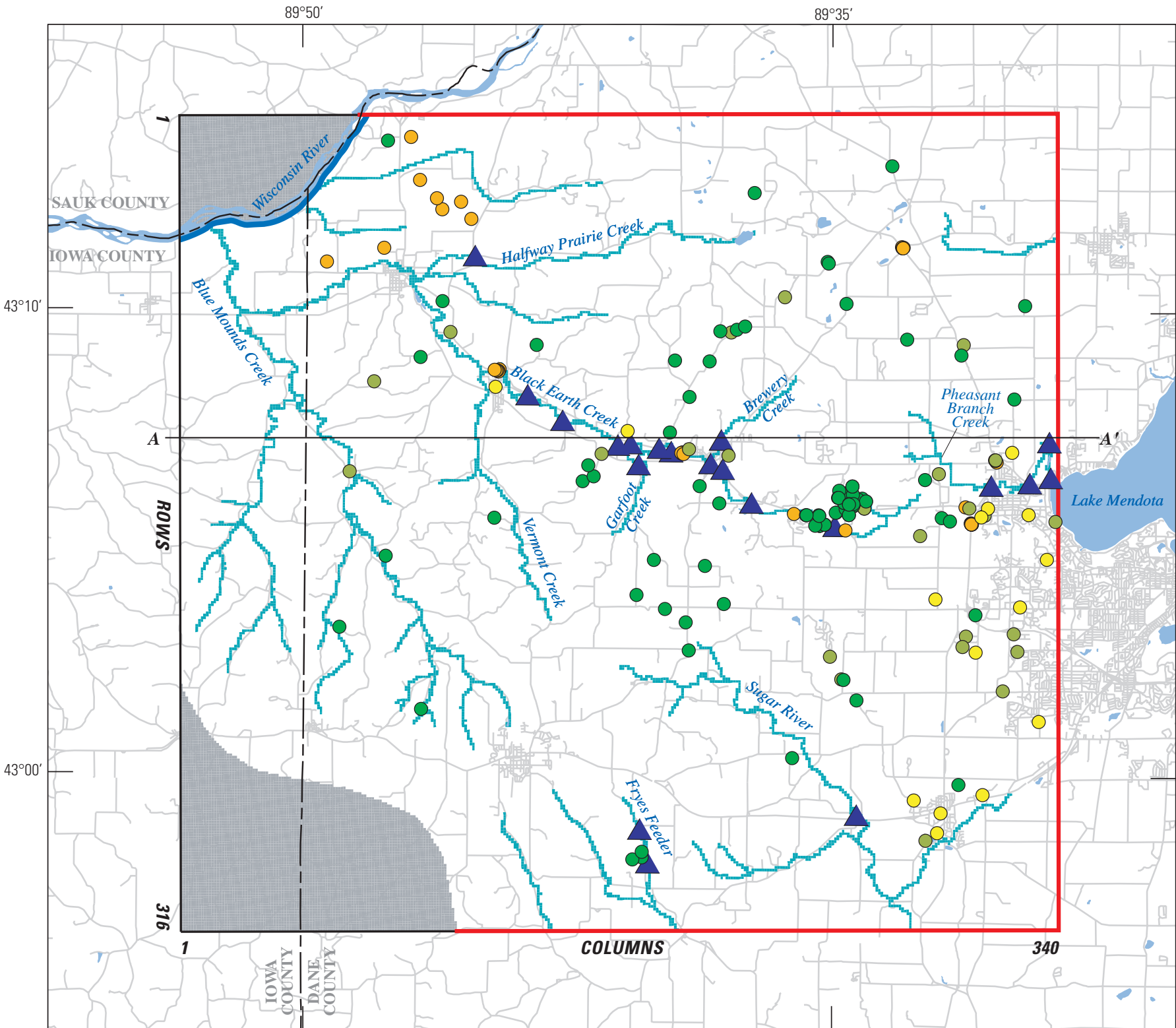

Base from Wisconsin Department of Natural Resources, $1998,1: 24,000$

Referenced to the Wisconsin Transverse Mercato coordinate system of 1983 based on the 1991 adjustment to the North American Datum of 1983 (WTM83, NAD83 [1991])
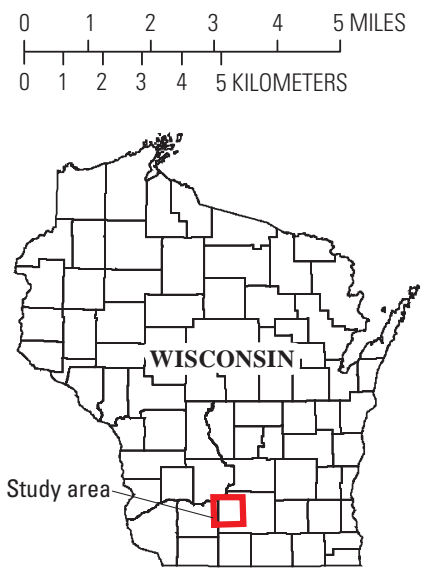

\section{EXPLANATION}

Regional feature

No flow cell

River cell

Stream cell

Specified flux perimeter boundary using rate extracted from Krohelski and others (2000)

MODFLOW boundary

A $\quad \mathbf{A}^{\prime}$ Trace of section shown in figure 1-3 MODFLOW-only head targets

Layer 1

Layers 2-4

Layer 5

Layer 6

Streamflow target

Figure 1-1. Black Earth Creek watershed MODFLOW model location, boundaries, groundwater elevation, and base flow targets. 


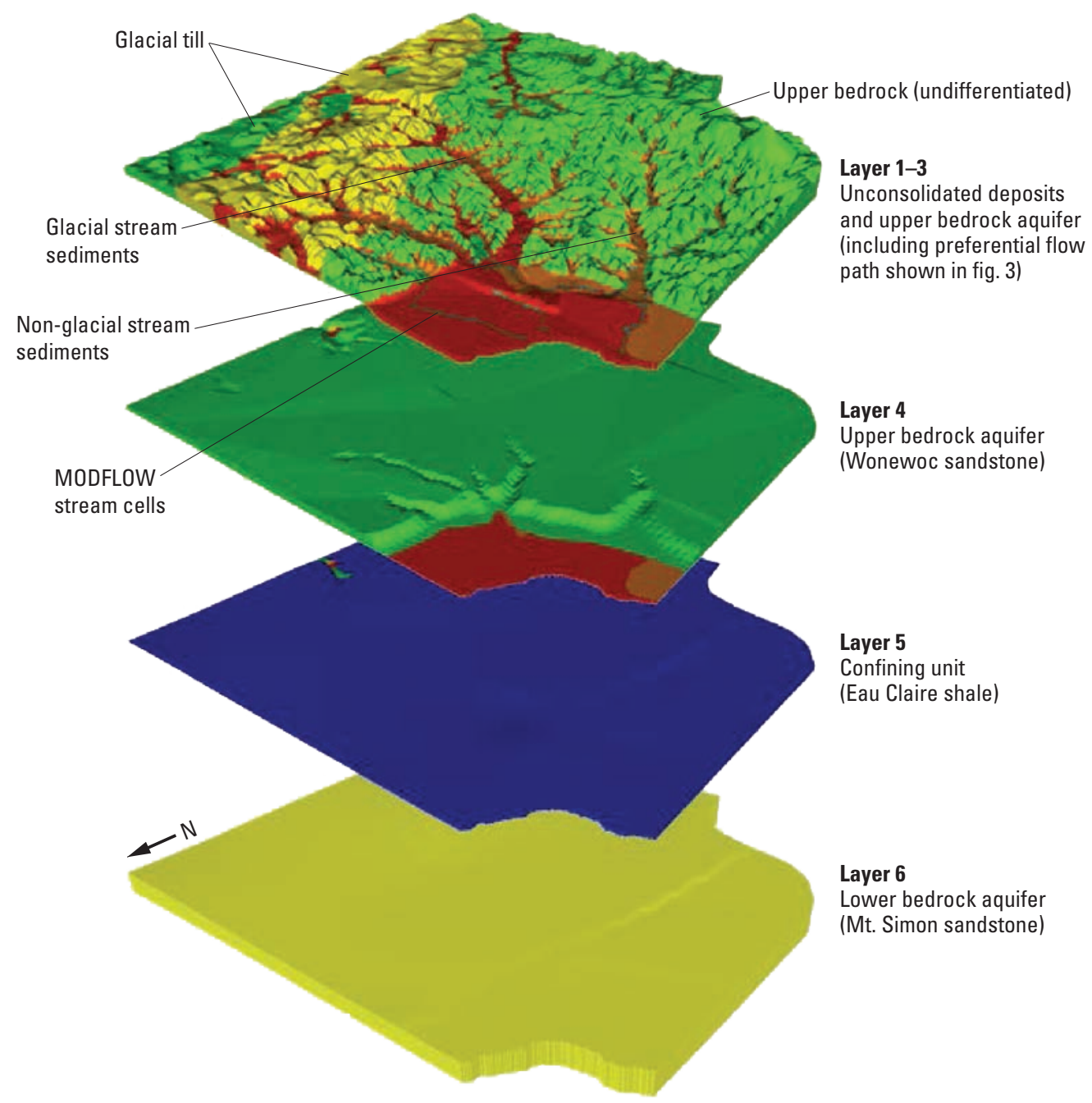

Figure 1-2. Black Earth Creek MODFLOW model layers, major hydrostratigraphic units, and stream cells.

well as the transient loading of water specified by the timevarying infiltration (input variable FINF) rate. Unsaturatedzone thickness also is used by UZF to simulate recharge and is calculated by subtracting the simulated water-table elevation from the land-surface elevation that is specified by the top elevation (input variable TOP) in MODFLOW's Layer Property Flow (LPF) Package. TOP is a critical parameter in the calculation of recharge within UZF, which differs from MODFLOW's Recharge (RCH) Package approach whereby the variable TOP for an unconfined top layer is commonly set to an arbitrary value because it is not used in most calculations of groundwater flow.

As described by Niswonger and others (2006), the UZF Package routes water through an assumed homogeneous unsaturated zone by using a one-dimensional kinematic wave approximation to Richards' equation that ignores capillary forces, and it can partition precipitation into evapotranspiration, runoff, unsaturated zone storage, and recharge. Two capabilities of the UZF Package are notable for model calibration. First, in transient models, water that leaves the root zone is routed through the unsaturated zone to the water table rather than being directly applied to the water table. This allows simulation of lags and mixing between infiltration events leaving the root zone before becoming water-table recharge. Second, the UZF Package can generate and route runoff to surface-water features in areas where the water table is at or above land surface or during periods when infiltration rates exceed the ability of the soil to transmit the water. This phenomenon is typically referred to as development of a "variable source area"; this capability can be invoked in steady-state and transient models (Hunt and others, 2008). More representative simulations of variable source areas result, which facilitate 
A

A

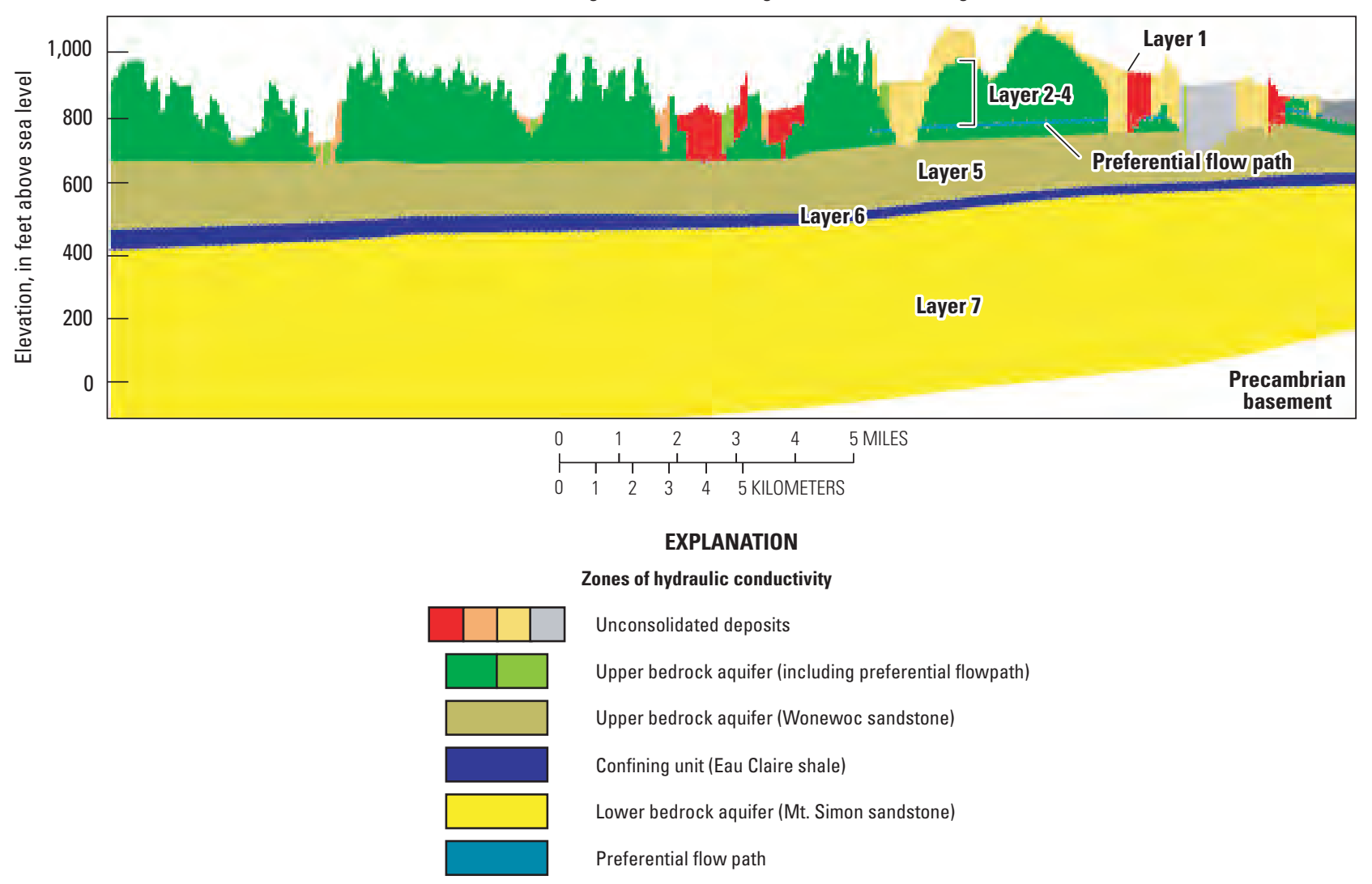

B

A

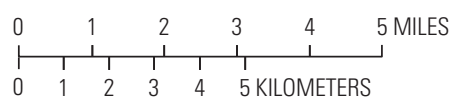

Figure 1-3. Layers and zones of hydraulic conductivity used in the calibrated groundwater model. Trace of section shown in figure 1-1. $A$, cross section with vertical exaggeration of about $100 \mathrm{X}$; $B$, the same cross section with no vertical exaggeration, reflecting the true dimensions of the system in the field.

more realistic simulations of groundwater/surface-water interaction dynamics. These areas represent potential variable source areas for surface-runoff generation when groundwater heads reach land surface and are therefore routed to surface water in the model through a UZF Package variable (the "Integer RUNoff BouNDry” or IRUNBND array; fig. 1-6) during model calibration. Moreover, the ability to remove and route water to adjacent surface-water features is superior to simulation of overpressurization of the groundwater system that can result from direct application of infiltration to the water table (Hunt and others, 2008). The fully coupled GSFLOW model does not use this explicit routing but instead routes overland flow by using surface-water hydrologic response unit cascades specified within the Precipitation-Runoff Modeling System surface-water model. 


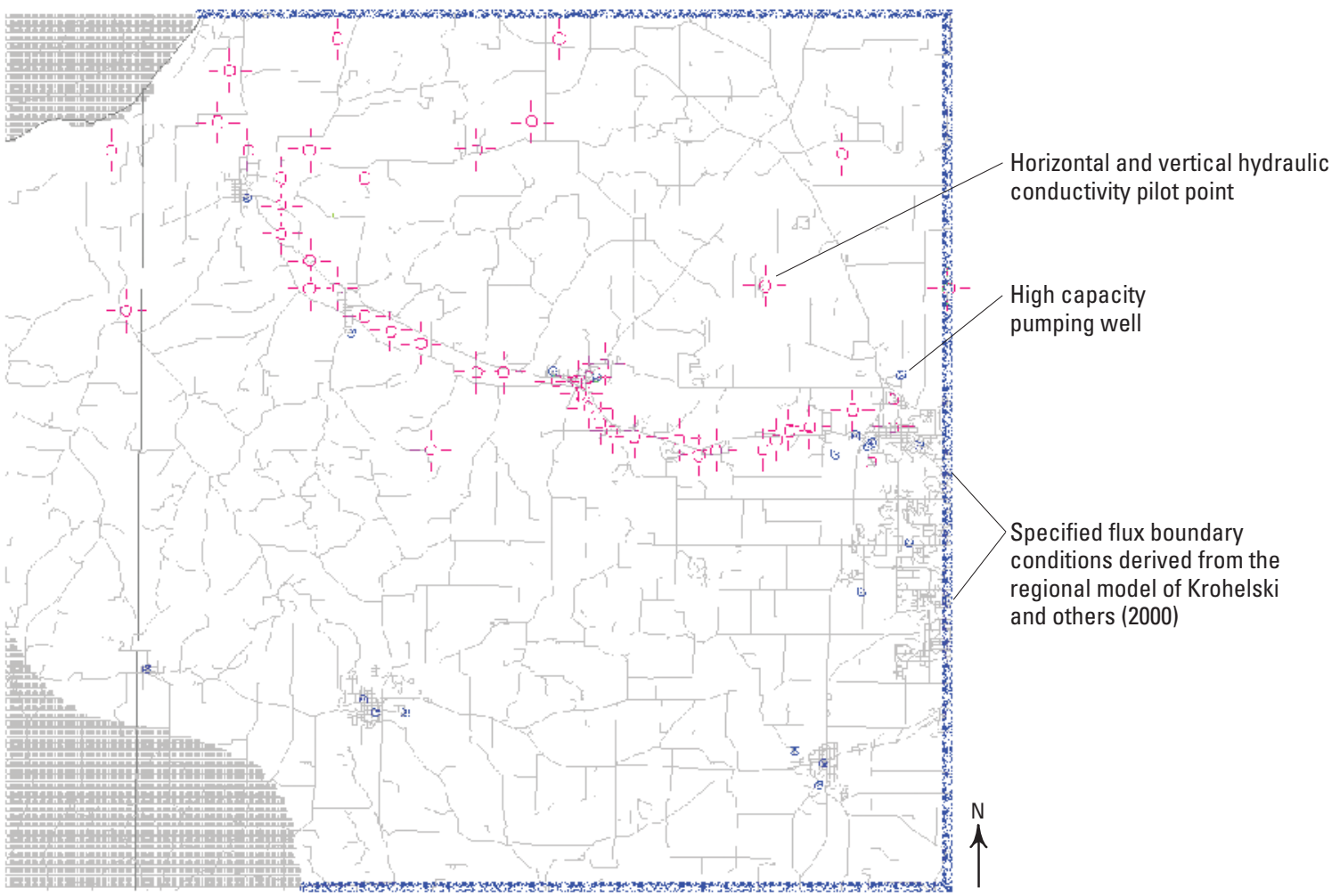

Figure 1-4. Location of the pilot points used for layers 1, 2, 3, and 5. Horizontal $\left(\mathrm{K}_{\mathrm{h}}\right)$ and vertical $\left(\mathrm{K}_{\mathrm{v}}\right)$ pilot points are collocated in layers 1 through 3 ; only $\mathrm{K}_{v}$ pilot points were used in layer 5 . Gray areas reflect inactive MODFLOW cells in layer 1.

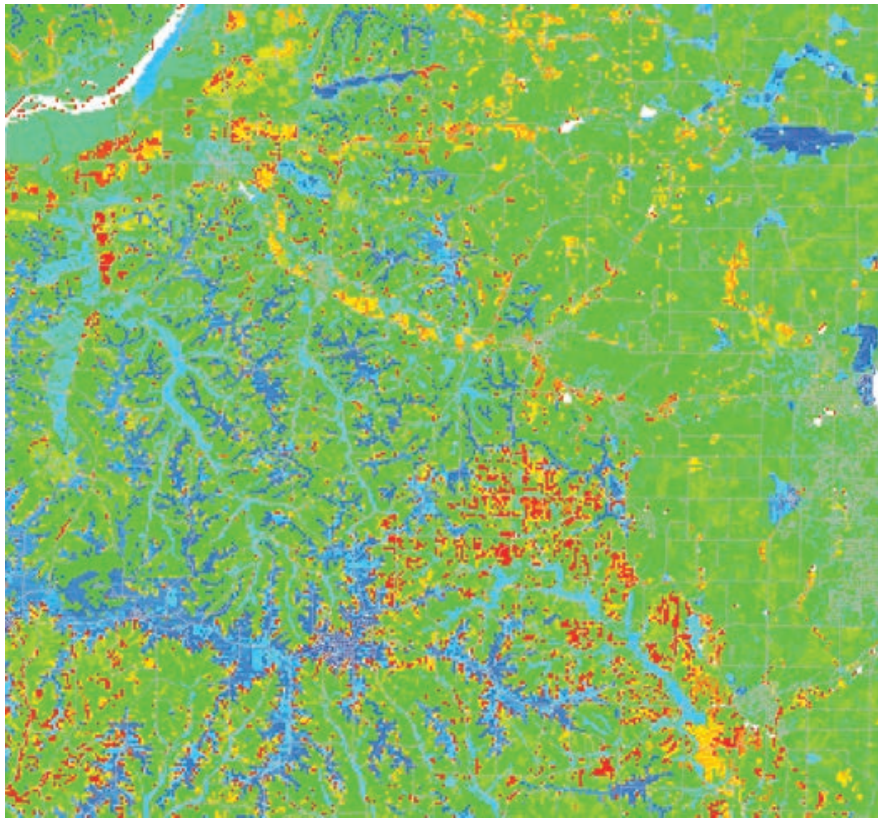

\section{EXPLANATION}

Recharge, in inches per year

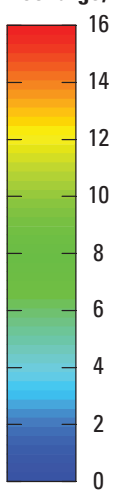

Figure 1-5. Recharge distribution calculated by the Soil-Water Balance approach of Westenbroek and others (2010). Warmer colors reflect higher recharge rates. Recharge rates were calibrated using a multiplier; thus, this relative distribution was retained even when the total recharge changed. Gray areas reflect inactive MODFLOW cells in layer 1. 


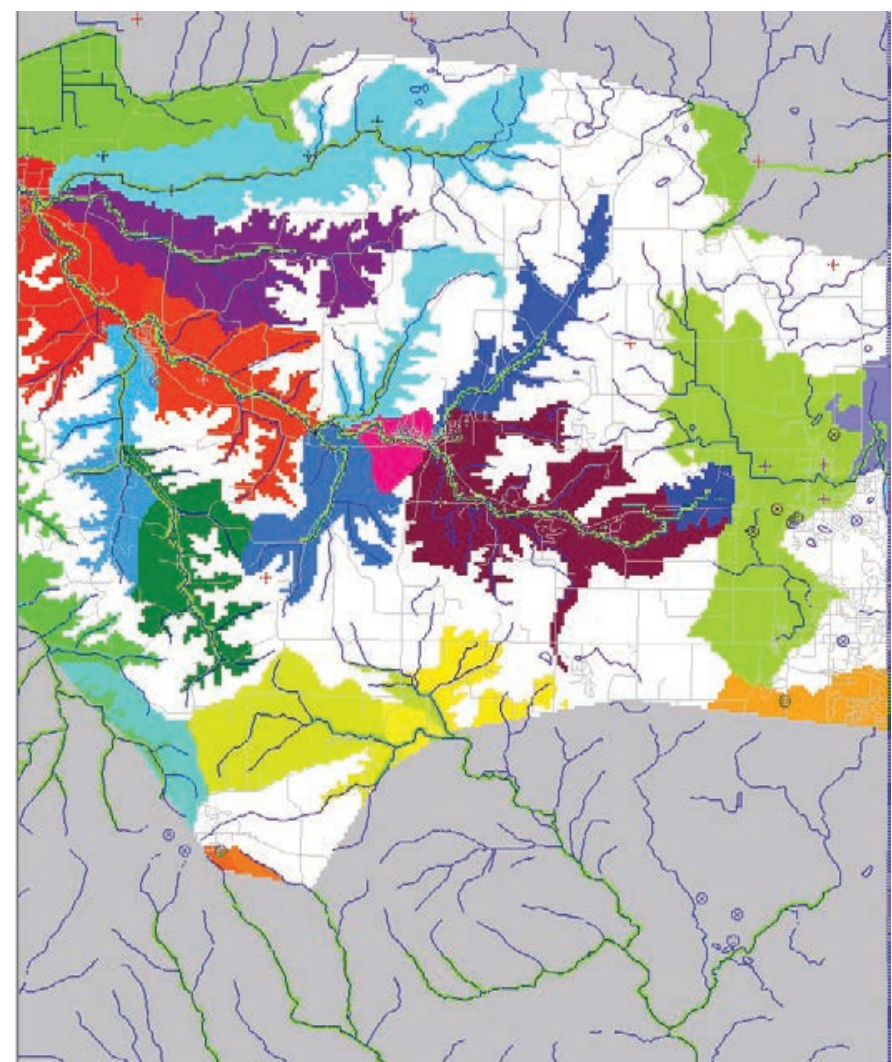

Figure 1-6. Unsaturated-Zone Flow (UZF) Package IRUNBND array used to route overland flow to surface-water features. Colored areas reflect areas grouped for routing; white represents areas where routing is not active.

\section{References Cited}

Anderson, K.M., 2002, Hydrogeologic controls on flow to Frederick Springs in the Pheasant Branch Watershed, Middleton, WI: University of Wisconsin-Madison, Department of Geology and Geophysics, M.S. Thesis, 172 p.

Bradbury, K.R., Swanson, S.K., Krohelski, J.T., and Fritz, A.K., 1999, Hydrogeology of Dane County, Wisconsin: Wisconsin Geological and Natural History Survey OpenFile Report 1999-04, 66 p.

Brown, B.A., Peters, R.M., and Massie-Ferch, K., 2013, Preliminary bedrock geology of Dane County, Wisconsin: Wisconsin Geological and Natural History Survey Plate WOFR2013-01-plate01, 1 p.

Clayton, L., and Attig, J.W., 1997, Pleistocene geology of Dane County, Wisconsin: Wisconsin Geological and Natural History Survey, Bulletin 95, 64 p.
Cline, D.Z., and Busby, M.W., 1963, Hydrology of Upper Black Earth Creek Basin, Wisconsin: U.S. Geological Survey Water-Supply Paper 1669-C, 27 p.

Doherty, John, 2003, Groundwater model calibration using pilot points and regularization: Ground Water, v. 41, no. 2, p. $170-177$.

Doherty, J.E., Fienen, M.N., and Hunt, R.J., 2010, Approaches to highly parameterized inversion-Pilot-point theory, guidelines, and research directions: U.S. Geological Survey Scientific Investigations Report 2010-5168, 36 p.

Harbaugh, A.W., 2005, MODFLOW-2005, the U.S. Geological Survey modular ground-water model-The groundwater flow process: U.S. Geological Survey Techniques and Methods, book 6, chap. A16 [variously paged].

Hunt, R.J., Doherty, J., and Tonkin, M.J., 2007, Are models too simple? Arguments for increased parameterization: Ground Water, v. 45, no. 3, p. 254-261, doi:10.1111/j.17456584.2007.00316.x

Hunt, R.J., Prudic, D.E., Walker, J.F., and Anderson, M.P., 2008, Importance of unsaturated zone flow for simulating recharge in a humid climate: Ground Water, v. 46, no. 4, p. 551-560, doi:10.1111/j.1745-6584.2007.00427.x.

Hunt, R.J., and Steuer, J.J., 2000, Simulation of the recharge area for Frederick Springs, Dane County, Wisconsin: U.S. Geological Survey Water-Resources Investigations Report 00-4172, 33 p.

Hunt, R.J., Steuer, J.J., Mansor, M.T.C., and Bullen, T.D., 2001, Delineating a recharge area for a spring using numerical modeling, Monte Carlo techniques, and geochemical investigation: Ground Water, v. 39, no. 5, p. 702-712, doi:10.1111/j.1745-6584.2001.tb02360.x

Krohelski, J.T., Bradbury, K.R., Hunt, R.J., and Swanson, S.K., 2000, Numerical simulation of ground-water flow in Dane County, Wisconsin: Wisconsin Geological and Natural History Survey Bulletin, v. 98, 31 p.

Markstrom, S.L., Niswonger, R.G., Regan, R.S., Prudic, D.E., and Barlow, P.M., 2008, GSFLOW-Coupled GroundWater and Surface-Water Flow Model based on the integration of the Precipitation-Runoff Modeling System (PRMS) and the Modular Ground-Water Flow Model (MODFLOW-2005): U.S. Geological Survey Techniques and Methods, book 6, chap. D1, 240 p.

McLeod, R.S., 1975a, A digital-computer model for estimating drawdowns in the sandstone aquifer in Dane County, Wisconsin: Wisconsin Geological and Natural History Survey Information Circular 28, 91 p. 
McLeod, R.S., 1975b, A digital-computer model for estimating hydrologic changes in the aquifer system in Dane County, Wisconsin: Wisconsin Geological and Natural History Survey Information Circular 30, 40 p.

Niswonger, R.G., and Prudic, D.E., 2005, Documentation of the Streamflow-Routing (SFR2) Package to include unsaturated flow beneath streams-A modification to SFR1: U.S. Geological Survey Techniques and Methods, book 6, chap. A13, 51 p.

Niswonger, R.G., Prudic, D.E., and Regan, R.S., 2006, Documentation of the Unsaturated-Zone Flow (UZF1) Package for modeling unsaturated flow between the land surface and the water table with MODFLOW-2005: U.S. Geological Survey Techniques and Methods, book 6, chap. A19, 74 p.

Swanson, S.K., 2001, Hydrologic controls on spring flow near Madison, Wisconsin: University of Wisconsin-Madison, Department of Geology and Geophysics, Ph.D. Thesis, 436 p.

Ward, D.S., Buss, D.R., Mercer, J.W., and Hughes, S.S., 1987, Evaluation of a groundwater corrective action at the ChemDyne hazardous waste site using a telescopic mesh refinement modeling approach: Water Resources Research, v. 23, no. 4, p. 603-617.

Westenbroek, S.M., Kelson, V.A., Dripps, W.R., Hunt, R.J., and Bradbury, K.R., 2010, SWB-A modified Thornthwaite-Mather Soil Water Balance code for estimating groundwater recharge. U.S. Geological Survey Techniques and Methods, book 6, chap. A31, 60 p. 


\section{Appendix 2. Surface-Water Model Construction}

The surface-water system was simulated using the Precipitation-Runoff Modeling System (PRMS) on a daily time step. PRMS is a modular, deterministic, distributed-parameter, physical-process basin model used to simulate and evaluate the effects of various combinations of precipitation, climate, and land use on basin response (Markstrom and others, 2015) This section contains additional detail regarding the development and initial parameterization of the PRMS surface-water model.

\section{Grid Rotation}

The 30-meter digital elevation map (DEM) of Wisconsin (Gesch and others, 2002) was clipped, rotated, and resampled to coincide with the boundaries of the groundwater-model grid. All of the gridded data used in this phase of the project were rotated about the lower left-hand coordinate of the MODFLOW grid. Limitations in the ArcInfo grid format do not allow for grids to be rotated relative to underlying projection coordinates. Because two of the tools used to assist in the parameterization of the PRMS model rely on the ArcInfo gridded data format, it was necessary to rotate the grids before further processing could occur.

Shapefiles were rotated using Hawth's Analysis Tools (version 3.27, http://www.spatialecology.com). The coordinate system of the model grids and shapefiles basically applies a rotation to the Wisconsin Transverse Mercator projection (Wisconsin State Cartographer's Office, 2009). The pivot point and rotation amount applied are as follows:

$\begin{aligned} \text { Pivot point: } \mathrm{X} & =528502.53 \mathrm{~m}(\mathrm{WTM} 83 / 91) \\ \mathrm{Y} & =274871.65 \mathrm{~m}(\mathrm{WTM} 83 / 91) \\ \text { Rotation angle } & =-0.65 \text { degrees }\end{aligned}$

\section{Hydrologic Response Units}

The surface-water modules included in the GSFLOW framework require that the model domain be split into discrete subareas, known as hydrologic response units (HRUs). Each HRU is assumed to be homogeneous with respect to hydrologic and physical characteristics such as slope, vegetation, land use, or soil type. Initial HRU parameterization was performed by use of a custom R script (R Development Core Team, 2015) written for this project. Because the hydrologic system is dominated by groundwater flow, a combination of surface-elevation differences and variations in the water table was used to construct the drainage network, which was then further subdivided into the final HRUs.
The GIS Weasel (Viger and Leavesley, 2007) was used to process the DEM, first by filling sinks, followed by generation of a flow-direction grid. The surface flow-direction grid was subsequently processed by use of the GIS Weasel's routines to generate a stream network and an initial two-plane HRU map. A flow-direction grid describing groundwater movement was generated by repeating the process using a water-table map derived from steady-state MODFLOW model run results as discussed in appendix 1 (fig. 2-1).

The two-plane HRU maps were merged together and further subdivided with a shapefile of buffered stream reaches to allow for separation of the near-stream areas from the upland areas. The result was a model consisting of 780 HRUs (fig. 2-2).

\section{Surface-Water Routing}

The PRMS model allows for surface flow to be routed to downslope HRUs. Each connection between a pair of HRUs or between an HRU and a stream segment must be specified explicitly. These connections were generated by means of the GIS Weasel (Viger and Leavesley, 2007) using the flowlines derived from the land-surface topography. Modifications were made by hand where the script failed to make the connections between HRUs properly. The resulting overland flow routing diagram contains 591 HRU-to-HRU connections, 300 HRUto-stream connections, and $51 \mathrm{HRU}$-to-farfield connections (fig. 2-3).

The surface-water and groundwater divides in the Black Earth Creek watershed are known to differ from one another (Cline and Busby, 1963). The PRMS model can simulate this feature of the Black Earth Creek watershed by allowing groundwater flow to be routed by means of a separate set of routing connections. The groundwater routing connections were generated by means of the GIS Weasel using the flowlines derived from the water-table surface (fig. 2-1). The resulting groundwater flow routing diagram contains 781 HRU-to-HRU connections, 240 HRU-to-stream connections, and 49 HRU-to-farfield connections (fig. 2-3).

\section{Parameterization of the Model}

The PRMS model contains hundreds of user-specified parameter values that can be used to tailor the model to the specific area of study. Some of these parameters are more important than others. This section contains a description of how some of the more important initial parameter values were derived. 

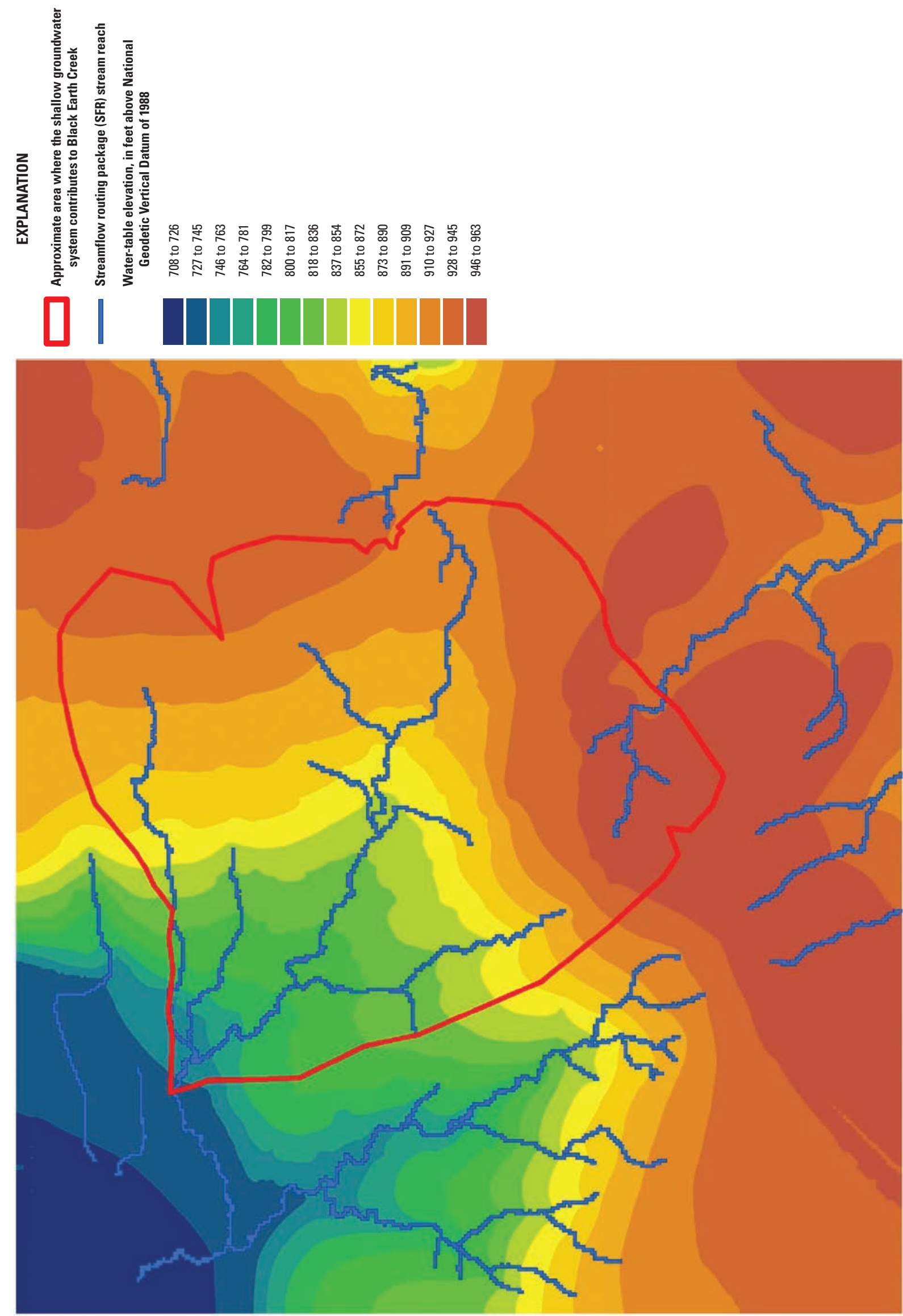

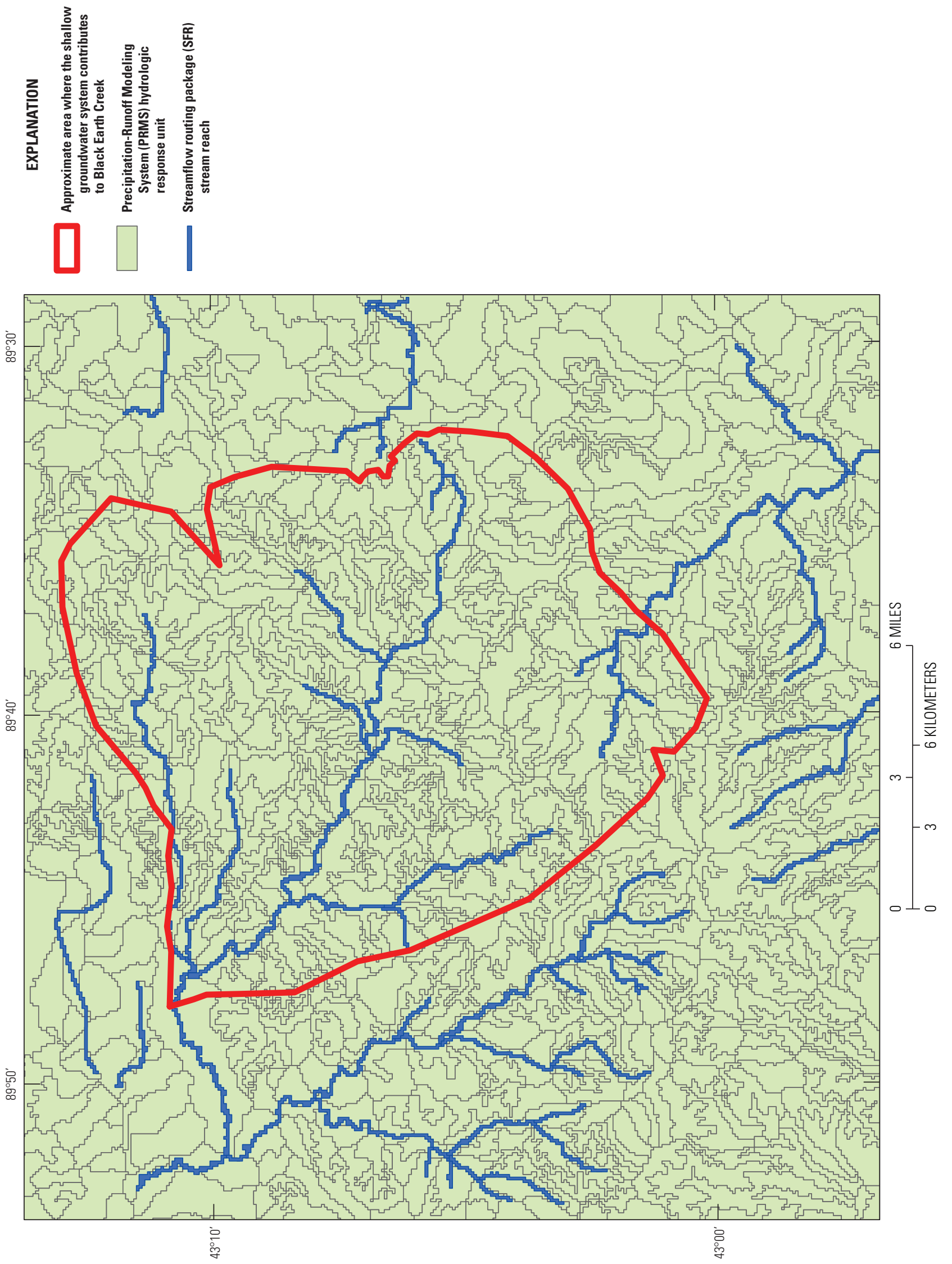

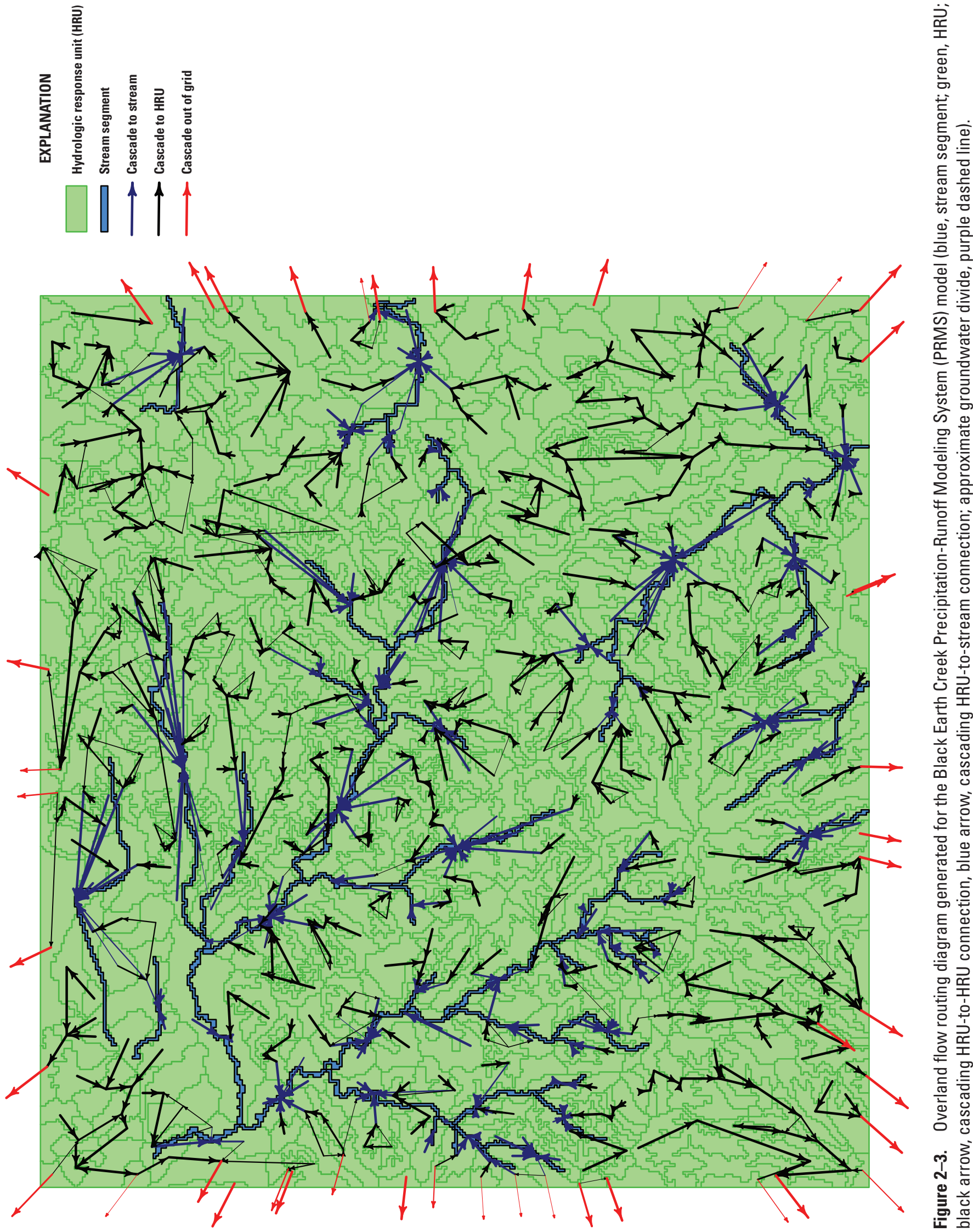

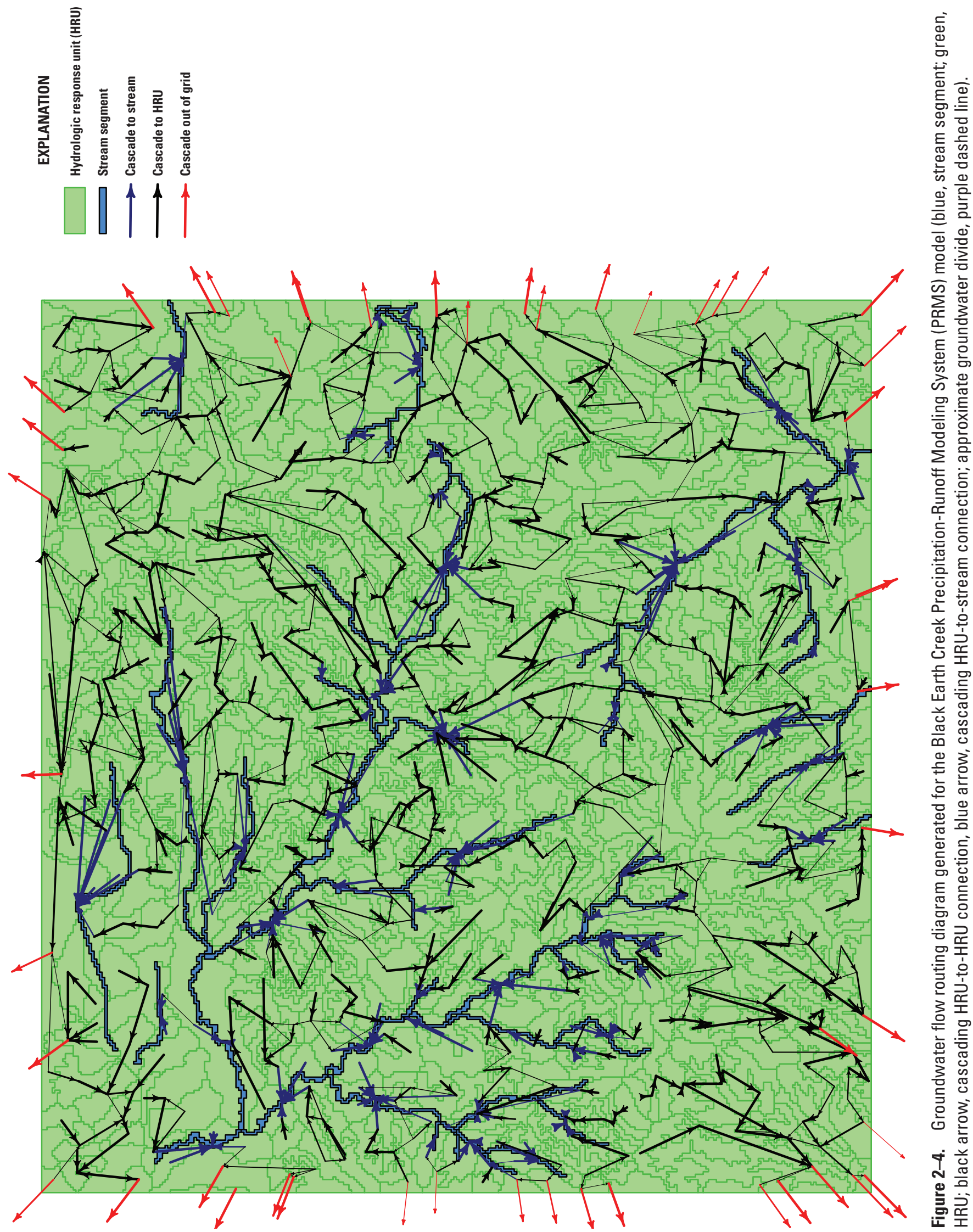
Initial parameter values were derived from recommended PRMS parameter value ranges (Leavesley and others, 1983). The values were assigned and distributed in accordance with HRU characteristics including HRU predominant land use, slope, aspect, soil type, and surficial glacial geology. The National Land Cover Database, 2001 edition (Eischeid and others, 2000), was used to assign majority land use codes to the HRUs. Surficial glacial geology was assigned on the basis of Pleistocene geology maps created for Dane County, Wisconsin (Clayton and Attig, 1997). Assignments were made in a similar manner as described in Viger and Leavesley (2007) by means of a custom R script.

A subset of the PRMS parameters may logically be associated with the predominant land use present within an HRU. The assumed values for a set of PRMS parameters relating to vegetative cover type, cover density, and interception rates relative to the predominant HRU land use are shown in table $2-1$.

Another set of parameters was distributed to the PRMS HRUs on the basis of an assumed relation between the predominant surficial glacial geology within the HRU. The assumed values for parameters relating to surface-water flow rates from the HRUs are shown in table 2-2.

The values of certain groundwater and soil related parameters as they were assumed to relate to the predominant surficial glacial geology within an HRU are shown in table 2-3.

Lastly, there is a small group of parameters that were determined through a calibration exercise that applied the Luca (Hay and Umemoto, 2007) calibration package to the Black Earth Creek PRMS model for a small subset of model parameters. These parameters are dday_slope and dday_intcp, which involve the estimation of solar radiation from air temperature data, and jh_coef, which involves the estimation of potential evapotranspiration. The parameters given in table 2-4 were generated as part of a multi-objective calibration exercise (L.E. Hay, U.S. Geological Survey, written commun., 2009).

\section{Climate Data Used for Model Forcing}

The PRMS model uses climate data as input to the hydrologic system. Daily values of precipitation and air temperature (maximum and minimum) are required inputs. Values of solar radiation and potential evapotranspiration can be input as specified data or calculated by the model. For this study, we chose to calculate these quantities using the cloud-cover solarradiation algorithm (ccsolrad_prms; Markstrom and others, 2008, p. 162) and the Jenson-Haise formulation for potential evapotranspiration (potet_jh_prms module; Markstrom and others, 2008, p. 164).

Data from a total of 26 precipitation stations and 19 air temperature stations were supplied to PRMS to simulate the hydrology of Black Earth Creek (table 2-5; fig. 2-5). The precipitation stations were either part of the U.S. Geological Survey streamgaging network, or were part of the National Oceanic and Atmospheric Administration's (NOAA) Cooperative Observer Network (COOP) program. Air temperature data were from the NOAA COOP program (National Climatic Data Center, 2004). In addition, a cooperator who lives in Mazomanie contributed data from a weather station situated in his backyard.

Table 2-1. Parameters assumed to be related to the predominant land use within each hydrologic response unit (HRU).

[HRU, hydrologic response unit]

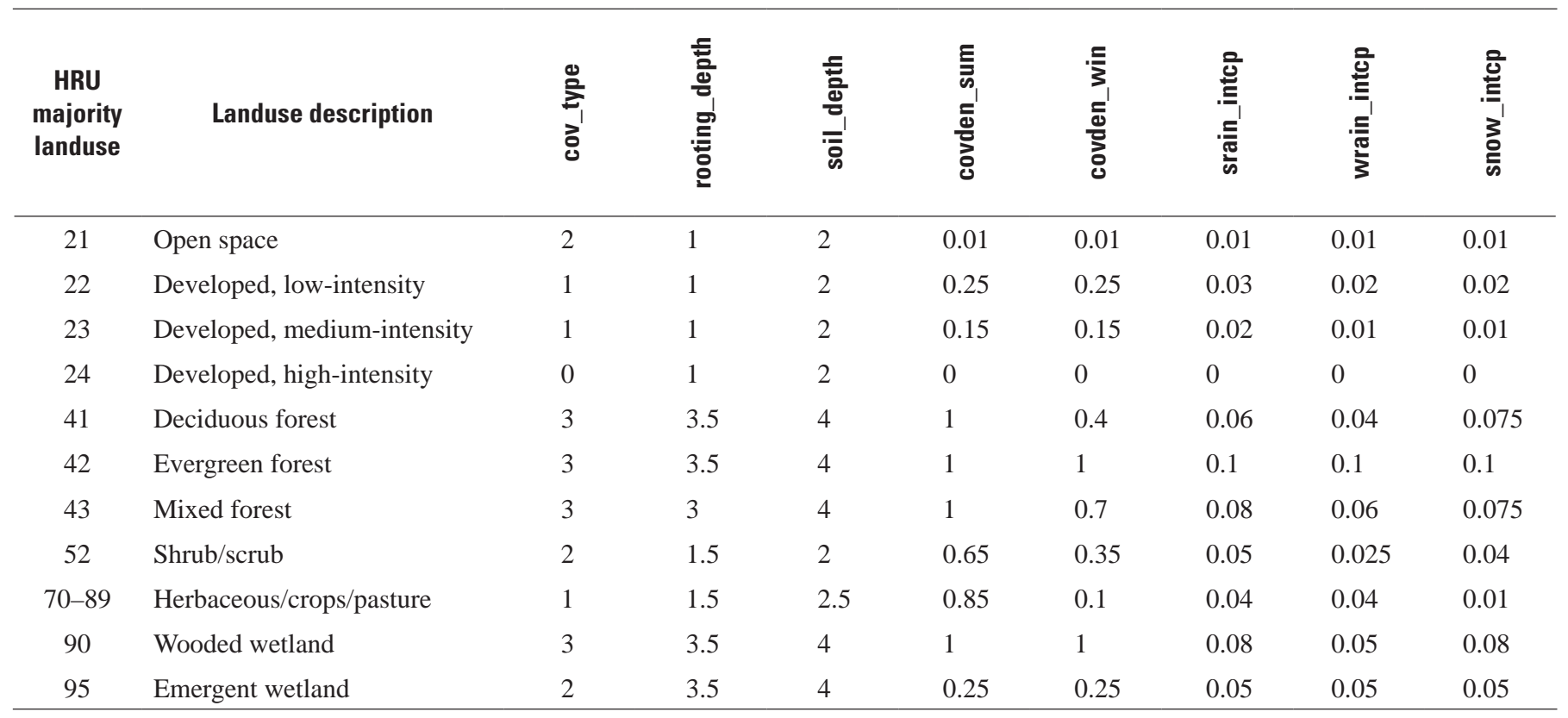


Table 2-2. Surface-water flow parameters assumed to be related to the predominant surficial glacial material in each hydrologic response unit (HRU).

\begin{tabular}{|c|c|c|c|c|c|c|c|c|c|c|}
\hline $\begin{array}{c}\text { Glacial } \\
\text { geology } \\
\text { code }\end{array}$ & $\begin{array}{c}\text { Glacial } \\
\text { geology } \\
\text { symbol }\end{array}$ & $\begin{array}{c}\text { Glacial geology } \\
\text { description }\end{array}$ & 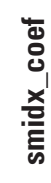 & 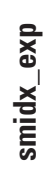 & 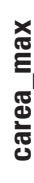 & 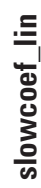 & 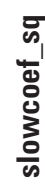 & 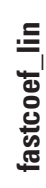 & 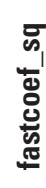 & $\frac{3}{4}$ \\
\hline
\end{tabular}

\begin{tabular}{|c|c|c|c|c|c|c|c|c|c|c|c|}
\hline 11 & $\mathrm{w}$ & Windblown sand & 0.0005 & 0.2 & 0.025 & 0.04 & 0.3 & 0.3 & 1 & 0.02 & 5 \\
\hline 21 & sm & $\begin{array}{l}\text { Nonglacial stream } \\
\text { sediment, modern } \\
\text { river }\end{array}$ & 0.001 & 0.21 & 0.25 & 0.015 & 0.15 & 0.12 & 0.8 & 0.08 & 0.5 \\
\hline 22 & sp & $\begin{array}{l}\text { Nonglacial stream } \\
\text { sediment, pre- } \\
\text { modern river }\end{array}$ & 0.001 & 0.21 & 0.25 & 0.015 & 0.1 & 0.1 & 0.8 & 0.08 & 0.5 \\
\hline 31 & su & $\begin{array}{l}\text { Glacial meltwater } \\
\text { sediment, } \\
\text { uncollapsed, flat } \\
\text { outwash plains }\end{array}$ & 0.0005 & 0.2 & 0.05 & 0.03 & 0.3 & 0.3 & 0.95 & 0.04 & 1 \\
\hline 32 & sc & $\begin{array}{l}\text { Glacial meltwater } \\
\text { sediment, collapsed, } \\
\text { hummocky }\end{array}$ & 0.0005 & 0.2 & 0.05 & 0.025 & 0.25 & 0.25 & 0.9 & 0.08 & 1 \\
\hline 33 & se & $\begin{array}{l}\text { Glacial meltwater } \\
\text { sediment, eroded, } \\
\text { gullied topography }\end{array}$ & 0.0005 & 0.21 & 0.05 & 0.02 & 0.2 & 0.2 & 0.85 & 0.1 & 1 \\
\hline 34 & so & $\begin{array}{l}\text { Glacial meltwater } \\
\text { sediment, overlain } \\
\text { with organic } \\
\text { postglacial } \\
\text { sediment }\end{array}$ & 0.0005 & 0.23 & 0.1 & 0.01 & 0.12 & 0.1 & 0.1 & 0.1 & 0.75 \\
\hline 41 & og & $\begin{array}{l}\text { Offshore lake } \\
\text { sediment, mostly } \\
\text { uncollapsed }\end{array}$ & 0.01 & 0.24 & 0.2 & 0.000001 & 0.000001 & 0.09 & 0.7 & 0.05 & 0.2 \\
\hline 42 & op & $\begin{array}{l}\text { Offshore lake } \\
\text { sediment, overlain } \\
\text { with postglacial } \\
\text { peat }\end{array}$ & 0.01 & 0.25 & 0.3 & 0.000001 & 0.000001 & 0.07 & 0.65 & 0.07 & 0.2 \\
\hline 43 & ое & $\begin{array}{l}\text { Offshore lake } \\
\text { sediment, eroded }\end{array}$ & 0.01 & 0.24 & 0.2 & 0.000001 & 0.000001 & 0.08 & 0.6 & 0.05 & 0.2 \\
\hline 51 & gs & Glacial till, sub-glacial & 0.0025 & 0.23 & 0.2 & 0.01 & 0.15 & 0.15 & 0.9 & 0.05 & 0.4 \\
\hline 52 & gh & $\begin{array}{l}\text { Glacial till, supra- } \\
\text { glacial, hummocky }\end{array}$ & 0.005 & 0.25 & 0.25 & 0.000001 & 0.000001 & 0.12 & 0.65 & 0.2 & 0.3 \\
\hline 55 & gk & $\begin{array}{l}\text { Glacial till, supra- } \\
\text { glacial, even more } \\
\text { hummocky }\end{array}$ & 0.005 & 0.27 & 0.3 & 0.000001 & 0.000001 & 0.1 & 0.6 & 0.2 & 0.3 \\
\hline 71 & ge & $\begin{array}{l}\text { Glacial till, supra- } \\
\text { glacial, eroded } \\
\text { slope }\end{array}$ & 0.005 & 0.24 & 0.2 & 0.000001 & 0.000001 & 0.08 & 0.75 & 0.2 & 0.3 \\
\hline 81 & $\mathrm{~h}$ & $\begin{array}{l}\text { Unglaciated hillslope } \\
\text { and upland }\end{array}$ & 0.001 & 0.21 & 0.1 & 0.015 & 0.12 & 0.1 & 0.8 & 0.1 & 0.6 \\
\hline 99 & wtr & Open water & 0.3 & 0.5 & 1 & 1 & 1 & 1 & 1 & 0.2 & 0 \\
\hline
\end{tabular}


The temperature and precipitation data from the weather stations were distributed to the HRUs by means of the PRMS module ide_dist. This module distributes temperature and precipitation values to the HRUs by interpolating horizontally and vertically between the nearest climate stations that have valid results. More details may be found in the PRMS manual (Markstrom and others, 2015).

\section{Variation of Growing Season with Changing Temperatures}

The growing season determines the period during which evapotranspiration from the vegetative portion of the HRUs can occur. It can be specified by two parameters: spring frost and fall frost. The spring frost parameter specifies the date for each HRU that is the beginning of the growing season. Likewise, the fall_frost parameter specifies the date for each HRU

Table 2-3. Groundwater and soil parameters assumed to be related to the predominant surficial glacial geology within a hydrologic response unit (HRU).

\begin{tabular}{|c|c|c|c|c|c|c|c|}
\hline $\begin{array}{l}\text { Glacial } \\
\text { geology } \\
\text { code }\end{array}$ & $\begin{array}{l}\text { Glacial } \\
\text { geology } \\
\text { symbol }\end{array}$ & Glacial geology description & 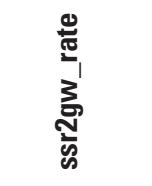 & 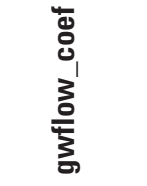 & 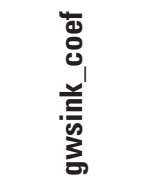 & $\sum_{\bar{\Sigma}}^{\triangleq}$ & 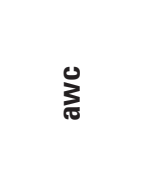 \\
\hline 11 & $\mathrm{w}$ & Windblown sand & 0.2 & 0.03 & 0.002 & 1 & 1.2 \\
\hline 22 & sp & $\begin{array}{l}\text { Nonglacial stream sediment, pre- } \\
\text { modern river }\end{array}$ & 0.05 & 0.004 & 0.0005 & 2 & 2 \\
\hline 31 & su & $\begin{array}{l}\text { Glacial meltwater sediment, } \\
\text { uncollapsed, flat outwash plains }\end{array}$ & 0.2 & 0.02 & 0.002 & 1 & 1 \\
\hline 34 & so & $\begin{array}{l}\text { Glacial meltwater sediment, } \\
\text { overlain with organic postglacial } \\
\text { sediment }\end{array}$ & 0.1 & 0.015 & 0.001 & 2 & 1.6 \\
\hline 41 & og & $\begin{array}{l}\text { Offshore lake sediment, mostly } \\
\text { uncollapsed }\end{array}$ & 0.01 & 0.0005 & 0.0001 & 3 & 3.1 \\
\hline 42 & op & $\begin{array}{l}\text { Offshore lake sediment, overlain } \\
\text { with postglacial peat }\end{array}$ & 0.01 & 0.0005 & 0.0001 & 3 & 3.3 \\
\hline 71 & ge & $\begin{array}{l}\text { Glacial till, supra-glacial, eroded } \\
\text { slope }\end{array}$ & 0.025 & 0.001 & 0.00015 & 2 & 2.8 \\
\hline 81 & $\mathrm{~h}$ & Unglaciated hillslope and upland & 0.075 & 0.002 & 0.00038 & 2 & 2.4 \\
\hline 99 & wtr & Open water & $1.0 \times 10^{-12}$ & $1.0 \times 10^{-12}$ & $1.0 \times 10^{-12}$ & 1 & $1.0 \times 10^{-12}$ \\
\hline
\end{tabular}


that is the end of the growing season. Both parameters are calculated as a solar day, defined as the time in days since the winter solstice. The two frost parameters were preprocessed by means of an algorithm described in Christiansen and others (2011) and documented in Markstrom and others (2012). A killing-frost temperature of -2.2 degrees Celsius, 28 degrees Fahrenheit, was used for each HRU. During model calibration, the frost parameters were determined as average values for the calibration period. During climate-change scenarios, the frost parameters were determined for each year in the simulation period by using minimum temperature input for each specific general circulation model (GCM) and emissions scenario.

A preprocessing program calculates the spring frost date and fall frost date for each calendar year for each HRU. The program then produces an input file for the model consisting of transpiration flags for each day for each HRU, indicating whether transpiration is on (flag=1) or off (flag $=0$ ). The GSFLOW model uses the climate_hru module to read the transpiration flags directly from the input file.

\section{References}

Christiansen, D.E., Markstrom, S.L., and Hay, L.E., 2011, Impacts of climate change on the growing season in the United States: Earth Interactions, v. 15, no. 33, p. 1-17.

Clayton, L., and Attig, J.W., 1997, Pleistocene geology of Dane County, Wisconsin: Wisconsin Geological and Natural History Survey, Bulletin 95, 65 p.

Cline, D.R., and Busby, M.W., 1963, Hydrology of Upper Black Earth Creek Basin, Wisconsin: U.S. Geological Survey Water-Supply Paper 1669-C, 27 p. [Also available at http://pubs.er.usgs.gov/publication/wsp1669C].

Table 2-4. Parameters generated from a multi-objective calibration exercise.

\begin{tabular}{lccl}
\hline \multicolumn{1}{c}{ Month } & dday_slope & dday_intcp & jh_coef \\
\hline January & 0.420 & -7.40 & 0.0085 \\
February & 0.535 & -12.56 & 0.009 \\
March & 0.584 & -18.92 & 0.01 \\
April & 0.661 & -26.59 & 0.0096 \\
May & 0.707 & -39.33 & 0.01 \\
June & 0.842 & -58.08 & 0.01 \\
July & 1.079 & -79.87 & 0.0095 \\
August & 0.892 & -65.10 & 0.01 \\
September & 0.713 & -45.60 & 0.012 \\
October & 0.601 & -30.81 & 0.012 \\
November & 0.617 & -21.89 & 0.012 \\
December & 0.438 & -12.56 & 0.0085 \\
\hline
\end{tabular}

Eischeid, J.K., Pasteris, P.A., Diaz, H.F., Plantico, M.S., and Lott, N.J., 2000, Creating a serially complete, national daily time series of temperature and precipitation for the western United States: Journal of Applied Meteorology, v. 39, no. 9, p. 1580-1591.

Gesch, D., Oimoen, M., Greenlee, S., Nelson, C., Steuck, M., and Tyler, D., 2002, The national elevation dataset: Photogrammetric Engineering and Remote Sensing, v. 68, p. 5-12.

Hay, L.E., and Umemoto, M., 2007, Multiple-objective stepwise calibration using Luca: U.S. Geological Survey OpenFile Report 2006-1323, 25 p., accessed December 1, 2015, at http://pubs.er.usgs.gov/publication/ofr20061323.

Leavesley, G., Lichty, R., Troutman, B., and Saindon, L., 1983, Precipitation-runoff modeling system-User's manual: U.S. Geological Survey Water Resources Investigations Report 83-4238, accessed December 1, 2015, at https:// pubs.er.usgs.gov/publication/wri834238.

Markstrom, S.L., Hay, L.E., Ward-Garrison, D.C., Risley, J.C., Battaglin, W.A., Bjerklie, D.M., Chase, K.J., Christiansen, D.E., Dudley, R.W., Hunt, R.J., Koczot, K.M., Mastin, M.C., Regan, R.S., Viger, R.J., Vining, K.C., and Walker, J.F., 2012, Integrated watershed-scale response to climate change for selected basins across the United States: U.S. Geological Survey Scientific Investigations Report 2011-5077, 134 p., accessed December 1, 2015, at http:// pubs.er.usgs.gov/publication/sir20115077.

Markstrom, S.L., Regan, R.S., Hay, L.E., Viger, R.J., Webb, R.M.T., Payn, R.A., and LaFontaine, J.H., 2015, PRMSIV, the Precipitation-Runoff Modeling System, Version 4: U.S. Geological Survey Techniques and Methods, book 6, chap. B7, 158 p., accessed December 1, 2015, at http://pubs. usgs.gov/tm/6b7.

National Climatic Data Center, 2004, Climatography of the United States No. 20-Monthly station climate summaries, 1971-2000: Asheville, N.C., National Oceanic and Atmospheric Administration, 653 p.

R Development Core Team, 2015, R-A language and environment for statistical computing: Vienna, Austria, R Foundation for Statistical Computing, accessed December 1, 2015, at http://www.R-project.org/.

Viger, R.J., and Leavesley, G.H., 2007, The GIS Weasel User's Manual: U.S. Geological Survey Techniques and Methods, book 6, chap. B4, 201 p., accessed December 1, 2015, at http://pubs.usgs.gov/tm/2007/06B04/.

Wisconsin State Cartographer's Office, 2015, Wisconsin Coordinate Reference Systems (2d ed.): Madison, Wisconsin, State Cartographer's Office, 120 p. [Also available at http:// www.sco.wisc.edu/images/stories/publications/WisCoordRefSys_June2015.pdf.] 
Table 2-5. National Weather Service Cooperative Observer Network (COOP) and U.S. Geological Survey weather stations used to provide input to the Precipitation-Runoff Modeling System (PRMS) model.

[USGS ID, U.S. Geological Survey identification number; NOAA, National Oceanic and Atmospheric Administration; COOPID, Cooperator Observer Network identification number; WI, Wisconsin; na, not applicable]

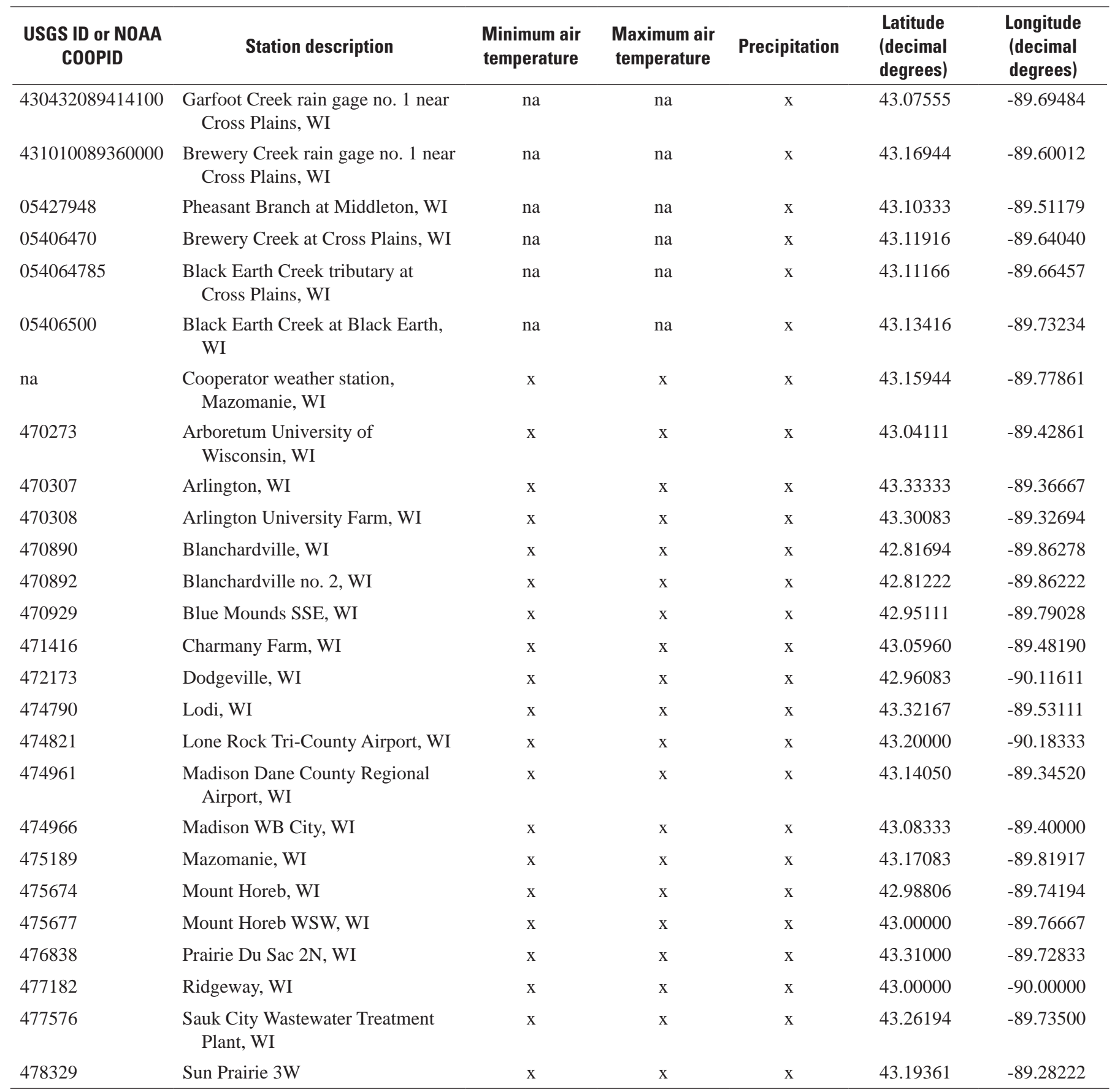



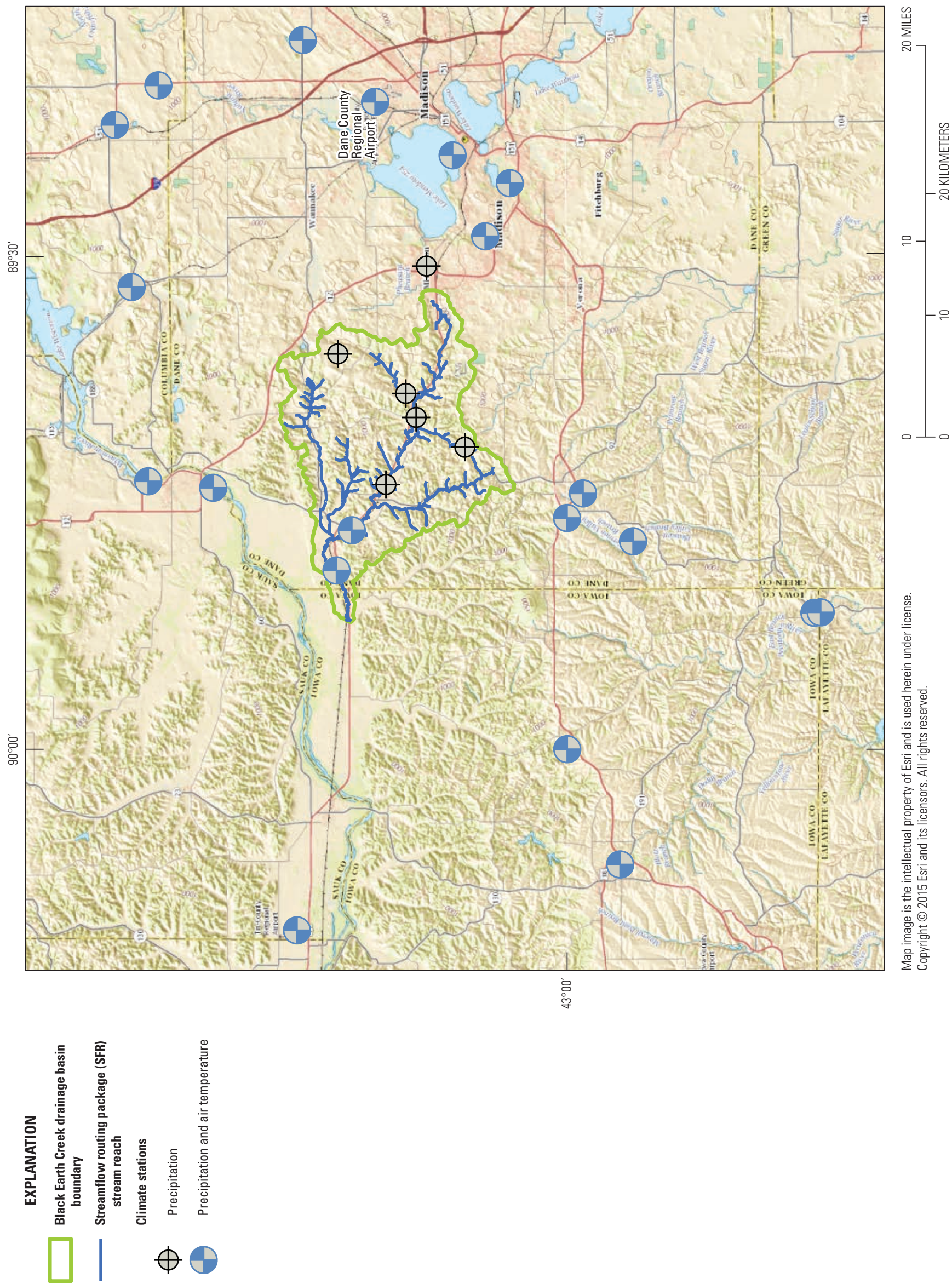

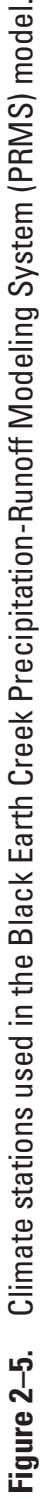




\section{Appendix 3. Model Calibration}

\section{Introduction}

The overall model-calibration strategy used the same approach as Hunt and others (2013). It involved calibrating the Precipitation-Runoff Modeling System (PRMS)-only and steady-state MODFLOW models independently as a first step. Then the complete coupled model was calibrated to further refine the parameters. For parameters related to the PRMS model and associated parameters in the coupled model, a stepwise procedure was used to isolate parameters controlling specific hydrologic processes (Hay and others, 2006).

\section{Time-Series Processing Approach}

In addition to issues of parameter insensitivity and correlation that affect coupled-model calibration (Doherty and Hunt, 2009, 2010a), there are also concerns with the issue of measurement/epistemic error noise and redundant information in the observations used to calibrate these models (Hunt and others, 2009). This is a primary concern here because surfacewater datasets commonly include many observations, especially with respect to the temporal density of the observations at a spatially distributed network; many of these data carry redundant insight into the system, as well as contribute to the measurement noise that is encountered during calibration. To enhance the signal-to-noise ratio within our observation data, we employed a time-series processing approach to the timeseries observations. In this approach, the raw observations were processed and distilled into characteristic aspects of the system (Walker and others, 2009) such as annual and monthly mean, and mean monthly flows. The simulated PRMS output was then processed in the same way as the raw observations and compared directly in the parameter-estimation process. We used the Time-Series Processor TSPROC (Doherty, 2008; Westenbroek and others, 2012), which allows the postprocessing to natively read the PRMS STATVAR and MODFLOW Gage (GAG) Package output files.

\section{Observation Weights}

In general, an estimate of uncertainty in the observations was the starting point for the weights for each observation group $\left(w_{q}\right)$. The weight was assigned to be the reciprocal of the uncertainty for each group, which is defined by the standard deviation of the data $\left(\sigma_{g}\right)$, thus

$$
w_{g}=\frac{1}{\sigma_{g}}
$$

where

$$
\begin{aligned}
& w_{g} \quad \text { is the weight for a particular observation } \\
& \text { group, and } \\
& \sigma_{g} \quad \text { is the standard deviation of the uncertainty } \\
& \text { for the observations. }
\end{aligned}
$$

The uncertainties were estimated by using the coefficient of variation (standard deviation divided by the mean) and an average value for each observation group; thus, the weight is estimated as

$$
w_{g}=\frac{1}{\mu_{g} C V_{g}}
$$

where

$$
\begin{gathered}
\mathrm{CV}_{\mathrm{g}} \quad \begin{array}{l}
\text { is the coefficient of variation for the } \\
\text { observation group, and }
\end{array} \\
\mu_{\mathrm{g}} \quad \begin{array}{l}
\text { is the average value for the observation } \\
\text { group. }
\end{array}
\end{gathered}
$$

For a log-transformed, normally distributed variable, the standard deviation in log space was determined by rearranging the equations relating log-space (y) to real space (x) (Miller and Freund, 1977):

$$
\sigma_{y}=\sqrt{\log \left(1+C V_{x}^{2}\right)} C V_{x}
$$

where

$$
\begin{gathered}
\mathrm{CV}_{\mathrm{x}} \quad \begin{array}{l}
\text { is the coefficient of variation of the real-space } \\
\text { observations, and }
\end{array} \\
\sigma_{\mathrm{x}} \quad \begin{array}{l}
\text { is the standard deviation of the log-space } \\
\text { observations. }
\end{array}
\end{gathered}
$$

Because the groups contained observations at different time scales, the number of observations differed considerably within each group and from station to station. To compensate for the number of observations, the weights were adjusted to represent an equivalent number of annual observations for step 1 and monthly observations for step 3 . This reasoning follows from the basic identity (Miller and Freund, 1977) that the standard deviation of the mean from a random sample of size $\mathrm{n}$ is given by the following equation

$$
\sigma_{m}=\frac{\sigma_{g}}{\sqrt{n}}
$$

where

$$
\begin{aligned}
& \sigma_{\mathrm{m}} \quad \begin{array}{l}
\text { is the standard deviation of the mean of the } \\
\text { observations, }
\end{array} \\
& \sigma_{\mathrm{g}} \quad \begin{array}{l}
\text { is the standard deviation for the observation } \\
\text { group, and }
\end{array} \\
& \mathrm{n} \\
& \text { is the sample size. }
\end{aligned}
$$


Because the weights are equal to the inverse of the standard deviation, the weight for a mean statistic becomes

$$
w_{m}=\frac{1}{\sigma_{m}}=\frac{\sqrt{n}}{\sigma_{g}}=w_{g} \sqrt{n}
$$

where

$$
\begin{aligned}
& w_{m} \quad \begin{array}{l}
\text { is the resulting weight for the mean of the } \\
\text { observation group, and }
\end{array} \\
& w_{g} \quad \begin{array}{l}
\text { is the base weight for the observation group } \\
\text { (from eq. 2). }
\end{array}
\end{aligned}
$$

After initial runs were performed, selected weights were adjusted manually to ensure that the information contained in the observation group was seen by the parameter estimation. Weights are subjective (Doherty and Hunt, 2010b), so the presentation focuses on results and parameters obtained; however, all weights used are available in the U.S. Geological Survey model archive associated with this report.

\section{Calibration Approach—Uncoupled Models}

The Black Earth Creek fully coupled model was incrementally calibrated by means of the parameter estimation program PEST (Doherty, 2014a, 2014b) using singular value decomposition. The PRMS surface-water model and the MODFLOW groundwater model were pre-calibrated before calibration of the fully coupled model. Sequential steps used in the first PRMS-only calibration are listed in table 3-1 (modified from Hay and others, 2006). Calibration efforts stayed within each step described below until all estimated parameters were within the bounds and seem to be reasonable for the hydrologic setting.

Table 3-1. Hydrologic processes associated with the individual steps in the Precipitation-Runoff Modeling System (PRMS)-only calibration procedure.

\begin{tabular}{cl}
\hline Step & \multicolumn{1}{c}{ Hydrologic processes } \\
\hline 1 & Solar radiation, potential evapotranspiration \\
2 & Snowmelt \\
3 & Runoff, infiltration, groundwater flow \\
\hline
\end{tabular}

\section{Step 1-Solar Radiation and Potential Evapotranspiration}

The first step in the parameter estimation process (table 3-2) involved estimating several parameters controlling incoming solar radiation and potential evapotranspiration (PET). The main driver for several of the hydrologic processes simulated in the PRMS model (for example, snowmelt and evapotranspiration) is incoming solar radiation. If the model is able to simulate incoming solar radiation correctly, parameters specific to other processes will be more realistic and likely to fall within acceptable ranges. Likewise, simulating PET correctly results in a more realistic simulation of infiltration, runoff, and groundwater-flow processes. Finally, simulating rather than specifying solar radiation allows for simulation of future climate conditions, where the amount of solar radiation is expected to differ from current or historic conditions (see appendix 2 for simulation method). Simulated values from other models, such as GCMs, could also be specified.

For this step, parameters associated with solar radiation and PET were used in the objective function. The following calibration targets were processed:

1. M ean monthly solar radiation.-Daily solar radiation for each month averaged across all years in the simulation period was used to capture the seasonal variation of solar radiation.

2. M ean monthly PET.-Daily PET for each month averaged across all years in the simulation period was used to capture the seasonal variation of PET.

Mean monthly solar radiation observations were obtained from a dataset developed for the United States by Hay and others (2006). The dataset consists of mean monthly values estimated at a network of climate-station sites (Snotel Telemetry and National Weather Service; http://www.wcc.nrcs.usda. gov/snow/; accessed April 7, 2016) by using multiple regression analysis. The mean monthly values of solar radiation for the site closest to the centroid of the Black Earth Creek watershed were used as the solar-radiation calibration target. Mean monthly PET estimates were obtained from mean monthly PET maps derived from the free-water evaporation atlas of Farnsworth and others (1982). The mean monthly values were interpolated to the centroid of the Black Earth Creek watershed to develop the PET calibration target. Unlike larger basins, the Black Earth Creek PRMS model was relatively insensitive to the spatial component of the Jenson-Haise relationship (parameter jh_coef_hru); therefore, a single PET target was assumed.

Parameters allowed to vary in this step included six parameters from the cloud-cover module (ccsolrad_prms; Markstrom and others, 2008, p. 162), two parameters from the PET module (potet_jh_prms module; Markstrom and others, 2008, p. 164), and one parameter from the soil-zone module (soilzone_prms; Markstrom and others, 2008, p. 169).

\section{Step 2-Snowmelt}

The second step of the parameter-estimation process involved parameters that control snow accumulation and melt throughout the watershed (table 3-3). The objective function for this group of parameters consisted of selected snowpack depths obtained from a nearby weather station (Truax Field) for the period October 1, 1999, to September 30, 2007. 
Table 3-2. Parameter types used in step 1 of the calibration: solar radiation and potential evapotranspiration.

[precip, precipitation; temp, temperature; PET, potential evapotranspiration; HRU, hydrologic response unit]

\begin{tabular}{|c|c|c|c|c|c|c|c|}
\hline \multirow{2}{*}{ Name } & \multirow{2}{*}{ Description } & \multicolumn{3}{|c|}{ Model-suggested values } & \multicolumn{3}{|c|}{ Calibrated values } \\
\hline & & Default & Minimum & Maximum & Average & Minimum & Maximum \\
\hline \multicolumn{8}{|c|}{ ccsolrad_prms module } \\
\hline ccov_intcp & $\begin{array}{l}\text { Monthly intercept in temperature } \\
\text { cloud cover relationship }\end{array}$ & 1.83 & 0 & 5 & 5 & 5 & 5 \\
\hline ccov_slope & $\begin{array}{l}\text { Monthly slope in temperature } \\
\text { cloud cover relationship }\end{array}$ & -0.13 & -0.5 & -0.01 & -0.04134 & -0.05182 & -0.02289 \\
\hline crad_coef & $\begin{array}{l}\text { Coefficient in cloud cover/solar } \\
\text { radiation relationship }\end{array}$ & 0.4 & 0.1 & 0.7 & 0.49409 & 0.49409 & 0.49409 \\
\hline crad_exp & $\begin{array}{l}\text { Exponent in cloud cover/solar } \\
\text { radiation relationship }\end{array}$ & 0.61 & 0.2 & 0.8 & 0.8 & 0.8 & 0.8 \\
\hline radj_sppt & $\begin{array}{l}\text { Adjustment to solar radiation on } \\
\text { precip day: summer }\end{array}$ & 0.44 & 0 & 1 & 1 & 1 & 1 \\
\hline radj_wppt & $\begin{array}{l}\text { Adjustment to solar radiation on } \\
\text { precip day: winter }\end{array}$ & 0.5 & 0 & 1 & 0.01333 & 0.01333 & 0.01333 \\
\hline \multicolumn{8}{|c|}{ potet_jh_prms module } \\
\hline jh_coef & $\begin{array}{l}\text { Monthly air temp coefficient: } \\
\text { Jensen-Haise PET }\end{array}$ & 0.014 & 0.005 & 0.06 & 0.01226 & 0.005 & 0.02746 \\
\hline jh_coef_hru & $\begin{array}{l}\text { HRU air temp coefficient: } \\
\text { Jensen-Haise PET }\end{array}$ & 13 & 5 & 20 & 5.07067 & 5.07067 & 5.07067 \\
\hline
\end{tabular}

Parameters allowed to vary in this stage included three from the precipitation module (climate_hru, Markstrom and others, 2015, p. 86-87), one from the interception module (intcp_prms; Markstrom and others, 2008, p. 165), and 10 from the snow computation module (snowcomp_prms; Markstrom and others, 2008, p. 166). Each of the parameters in table 3-3 was estimated as a single value. The most sensitive and identifiable parameters were tmax_allsnow, emis_noppt, den_max, adjust_snow, and den_init. Most of the remaining parameters remained relatively close to their starting values (0).

\section{Step 3-Runoff, Infiltration, and Base Flow Groundwater Flow}

The remaining step relies on processing daily streamflow data for the objective function targets. Data for water years 1985-2007 (October 1, 1985, to September 30, 2007) were used for the five long-term streamgages (fig. 1 in report) and other streamflow collected as part of the project (appendix 5). This step in the parameter-estimation process involved a group of parameters that control runoff, infiltration into the soil zone, and the rate and volume of flow from groundwater reservoirs to surface water (table 3-4). The following calibration targets were processed:

1. Log of daily streamflow: The natural log of daily streamflow was used to mitigate the undue influence of extremely high daily discharges.
2. Annual mean streamflow: This is the average streamflow for each water year during the simulation period and represents the streamflow portion of the annual hydrologic budget.

3. Monthly mean streamflow: This is the average streamflow for each month during the simulation and represents the total volume of streamflow for each month.

4. Monthly base flow: This is the average base flow for each month during the simulation and represents the groundwater contribution to streamflow. Daily base-flow separations were computed by using the local minimum algorithm from the TSPROC time-series processor (Westenbroek and others, 2012). The time-series processor uses the U.S. Geological Survey's HYSEP algorithms for computing base flow (Sloto and Crouse, 1996).

Parameters allowed to vary in this step included two from the climate distribution module (climate hru module; Markstrom and others, 2015, p. 86-87), two from the groundwater module (gwflow_casc_prms; Markstrom and others, 2008, p. 170), seven from the soil-zone module (soilzone prms; Markstrom and others, 2008, p. 169), and three from the runoff-generation module (srunoff_smidx_prms; Markstrom and others, 2008, p. 168). One parameter (adjust_rain) was varied by month, two parameters (smidx_coef and smidx_exp) were estimated with single values, and the remaining parameters were varied by subwatershed (table 3-4). The most sensitive and identifiable parameters were gwsink_coef, gwflow_coef, 
Table 3-3. Parameter types used in step 2 of the calibration: snowmelt.

[Precip, precipitation; HRU, hydrologic response unit; max, maximum; ET, evapotranspiration]

\begin{tabular}{|c|c|c|c|c|c|c|c|}
\hline \multirow{2}{*}{ Name } & \multirow{2}{*}{ Description } & \multicolumn{3}{|c|}{ Model-suggested values } & \multicolumn{3}{|c|}{ Calibrated values } \\
\hline & & Default & Minimum & Maximum & Average & Minimum & Maximum \\
\hline \multicolumn{8}{|c|}{ climate_hru_prms module } \\
\hline adjust_snow & $\begin{array}{l}\text { Monthly downscaling fractional } \\
\text { adjustment for snow for each } \\
\text { HRU }\end{array}$ & 0.01 & -0.25 & 1 & 0.06988 & -0.25 & 0.5 \\
\hline tmax_allsnow & $\begin{array}{l}\text { Precip all snow if HRU max } \\
\text { temperature below this value }\end{array}$ & 32 & -10 & 40 & 32.77165 & 32.77165 & 32.77165 \\
\hline \multicolumn{8}{|c|}{ intcp_prms module } \\
\hline potet_sublim & $\begin{array}{l}\text { Proportion of potential ET that is } \\
\text { sublimated from snow surface }\end{array}$ & 0.5 & 0.1 & 0.75 & 0.75 & 0.75 & 0.75 \\
\hline albset_rnm & Albedo reset: rain, melt stage & 0.6 & 0 & 1 & 0.07764 & 0.07764 & 0.07764 \\
\hline albset_sna & $\begin{array}{l}\text { Albedo reset: snow, accumulation } \\
\text { stage }\end{array}$ & 0.05 & 0.001 & 1 & 0.00351 & 0.00351 & 0.00351 \\
\hline albset_snm & Albedo reset: snow, melt stage & 0.2 & 0.001 & 1 & 0.06607 & 0.06607 & 0.06607 \\
\hline cecn_coef & $\begin{array}{l}\text { Monthly convection condensation } \\
\text { energy coefficient }\end{array}$ & 5 & 0 & 20 & 15.3375 & 15.3375 & 15.3375 \\
\hline den_init & Initial density of new-fallen snow & 0.1 & 0.01 & 0.5 & 0.0852 & 0.0852 & 0.0852 \\
\hline den_max & $\begin{array}{l}\text { Average maximum snowpack } \\
\text { density }\end{array}$ & 0.6 & 0.1 & 0.8 & 0.17371 & 0.17371 & 0.17371 \\
\hline
\end{tabular}

adjust_snow, and adjust_rain; however, several other parameters were moderately sensitive and identifiable, including soil_moist_max and carea_max.

\section{MODFLOW-Only Uncoupled Model}

The MODFLOW-only groundwater model was calibrated by using a parameter estimation program (PEST; Doherty, 2014a, 2014b). Nonsynchronous measurements from multiple time periods were used to maximize the number of calibration targets, which included the following steady-state targets:

1. Average base flows for May 1985, February 2007, and July 2007.
2. Average head conditions as represented by groundwater levels considered representative of average conditions during 1985-2007.

The overall calibration approach used here is one of regularized inversion (Hunt and others, 2007; Doherty and Hunt, 2010b) and differs from traditional nonlinear regression parameter estimation by the use of (1) pilot points (Doherty, 2003; Doherty and others, 2010) in addition to a traditional parameter zone approach, (2) Tikhonov regularization (Tikhonov, 1963a, 1963b; Doherty, 2003; Doherty and Hunt, 2010b), and (3) singular value decomposition (as suggested by Doherty and Hunt, 2010b). Additional information regarding the overview of the advantages of using these more 


\section{Simulation of Streamflow, Groundwater, and Stream Temperature in the Black Earth Creek Watershed}

Table 3-4. Parameter types used in step 3 of the calibration: runoff, infiltration, and groundwater flow.

[HRU, hydrologic response unit; GWR, groundwater reservoir]

\begin{tabular}{|c|c|c|c|c|c|c|c|}
\hline \multirow{2}{*}{ Name } & \multirow{2}{*}{ Description } & \multicolumn{3}{|c|}{ Model-suggested values } & \multicolumn{3}{|c|}{ Calibrated values } \\
\hline & & Default & Minimum & Maximum & Average & Minimum & Maximum \\
\hline \multicolumn{8}{|c|}{ climate_hru_prms module } \\
\hline adjust_rain & $\begin{array}{l}\text { Monthly downscaling } \\
\text { fractional adjustment for } \\
\text { rain for each HRU }\end{array}$ & 0.01 & -0.25 & 1 & 0.09447 & -0.25 & 0.44873 \\
\hline adjust_snow & $\begin{array}{l}\text { Monthly downscaling } \\
\text { fractional adjustment for } \\
\text { snow for each HRU }\end{array}$ & 0.01 & -0.25 & 1 & 0.06988 & -0.25 & 0.5 \\
\hline \multicolumn{8}{|c|}{ gwflow_casc_prms module } \\
\hline gwflow_coef & $\begin{array}{l}\text { Groundwater routing } \\
\text { coefficient for each GWR }\end{array}$ & 0.015 & 0 & 1 & 0.1257 & 0.0026 & 0.7501 \\
\hline gwsink_coef & $\begin{array}{l}\text { Groundwater sink coefficient } \\
\text { for each GWR }\end{array}$ & 0 & 0 & 1 & 0.06344 & 0.00000 & 0.56227 \\
\hline \multicolumn{8}{|c|}{ soilzone_prms module } \\
\hline sat_threshold & $\begin{array}{l}\text { Soil saturation threshold, } \\
\text { above field-capacity } \\
\text { threshold for each HRU }\end{array}$ & 999 & 1 & 999 & 6.78082 & 6 & 12 \\
\hline slowcoef_lin & $\begin{array}{l}\text { Linear gravity-flow reservoir } \\
\text { routing coefficient for } \\
\text { each HRU }\end{array}$ & 0.015 & 0 & 1 & 0.16588 & 0.00001 & 0.32746 \\
\hline slowcoef_sq & $\begin{array}{l}\text { Nonlinear gravity-flow } \\
\text { reservoir routing } \\
\text { coefficient for each HRU }\end{array}$ & 0.1 & 0 & 1 & 0 & 0 & 0.00001 \\
\hline soil_moist_max & $\begin{array}{l}\text { Maximum value of water for } \\
\text { soil zone for each HRU }\end{array}$ & 6 & 0 & 20 & 3.32745 & 0.4 & 5.02644 \\
\hline soil_rechr_max & $\begin{array}{l}\text { Maximum value for soil } \\
\text { recharge zone for each } \\
\text { HRU }\end{array}$ & 2 & 0 & 10 & 0.93202 & 0.06044 & 1.43793 \\
\hline soil2gw_max & $\begin{array}{l}\text { Maximum value for } \\
\text { soil-water excess to } \\
\text { groundwater for each } \\
\text { HRU }\end{array}$ & 0 & 0 & 5 & 0.1928 & 0 & 0.33234 \\
\hline ssr2gw_rate & $\begin{array}{l}\text { Coefficient to route water } \\
\text { from subsurface to } \\
\text { groundwater for each } \\
\text { HRU }\end{array}$ & 0.1 & 0 & 1 & 0.89838 & 0.11528 & 1.0 \\
\hline \multicolumn{8}{|c|}{ srunoff_smidx_prms module } \\
\hline carea_max & $\begin{array}{l}\text { Maximum contributing area } \\
\text { for each HRU }\end{array}$ & 0.6 & 0 & 1 & 0.08468 & 0 & 1 \\
\hline smidx_coef & $\begin{array}{l}\text { Coefficient in contributing } \\
\text { area computations for } \\
\text { each HRU }\end{array}$ & 0.01 & 0.0001 & 1 & 0.10286 & 0.10286 & 0.10286 \\
\hline smidx_exp & $\begin{array}{l}\text { Exponent in contributing } \\
\text { area computations for } \\
\text { each HRU }\end{array}$ & 0.3 & 0.2 & 0.8 & 0.2 & 0.2 & 0.2 \\
\hline
\end{tabular}


sophisticated tools for parameter estimation are discussed by Hunt and others (2007); the tools were applied in accordance with the guidelines given by Doherty and Hunt (2010b). A total of 379 adjustable parameter values were included in the MODFLOW-only calibration.

The pilot-point approach was used for (1) the horizontal and vertical hydraulic conductivity ( $\mathrm{K}_{\mathrm{h}}$ and $\mathrm{K}_{\mathrm{v}}$, respectively) of the glacio-fluvial Black Earth Creek sediments in the main stem of the creek valley and (2) for the $\mathrm{K}_{\mathrm{v}}$ of the Eau Claire shale (layer 5 ). The pilot points were initially placed using a grid and then augmented with additional pilot points to ensure appropriate coverage. A pilot-point approach allowed for a parameterization that it is not "hardwired" into specified zone geometries (Hunt and others, 2007). Other parameters such as glacial sediments and bedrock units were simulated using a zone approach, which reflects the higher confidence in their location and properties. Tikhonov regularization was used to inject "soft" information into the calibration process and to attain a unique solution to the inverse problem of model calibration. The Tikhonov condition was specified as a preferred difference (such as stating that the hydraulic conductivity should be uniform in this area). Doherty and Hunt (2010b) describe the PEST implementation of Tikhonov regularization in detail; briefly, the regularization process achieves this by supplementing the calibration observed dataset with a suite of pseudo observations, each of these pertaining to one or more parameters employed by the model, where the preferred condition is the "observation." Collectively, these provide a fallback position for parameters, or for relationships between parameters, in the event that little or no information resides in the observations in the calibration dataset. Apart from providing a fallback or default condition for parameters, and for relationships between them, Tikhonov regularization also provides constraints on the manner in which heterogeneity that is supported by the calibration dataset emerges in the estimated parameter field —only departures from background parameter fields that are geologically reasonable are used. Part of the art of formulating appropriate Tikhonov constraints for a particular parameter-estimation problem is to achieve a balance of good fit to measured data and reasonable parameters.

Soft-knowledge information was entered into the calibration by using Tikhonov regularization constraints. PEST adjusts the weights assigned to these equations such that all preferred conditions are seen as the objective function is minimized during the calibration process (Doherty, 2003, 2014a). The inversion process thus becomes a constrained minimization process in which a regularization objective function specifying adherence to the preferred system condition encapsulated in the regularization constraints is minimized subject to the constraint that the measurement objective function adheres to its user-specified target (if this can be achieved). This target is set on the basis of measurement noise considerations; however, as described by Doherty and Hunt (2010b), the appropriate tradeoff is specified by the modeler by way of the PHIMLIM variable in PEST and often requires review during the calibration process. If the PHIMLIM variable is set too low, parameter fields may become unrealistically variable as a result of fitting to noise; if set too high, parameter fields may fit the preferred condition too well, and the calibration process will fail to extract maximum information from the calibration dataset and the fit will be poor. The calibration used an established approach for setting PHILIM (Doherty and Hunt, 2010b, p. 20). Singular value decomposition tools in PEST (Doherty and Hunt, 2010b) were also used to ensure stability of the inversion.

\section{Calibration Approach-Fully Coupled Surface- Water/Groundwater Model}

After the calibration of the uncoupled MODFLOW and PRMS models, the MODFLOW and PRMS input files were slightly modified before the coupled model was run. Aquifer storage parameters and a second stress period was added to the optimal sequentially linked MODFLOW steady-state input files for GSFLOW runs; therefore, steady-state MODFLOW simulations provided initial conditions for all transient GSFLOW runs. Transient streamflow observations used to calibrate the fully coupled model were the same as used in the PRMS-only calibration. Transient head calibration used existing data and head data collected as part of this study. The existing datasets consisted of water levels for two wells collected by the Wisconsin Department of Natural Resources at the Refuse Hideaway Landfill in the upper reach of Black Earth Creek; these data spanned from 1991 to 2006. The new data consisted of a shorter dataset collected from six locations in the basin during 2005-6 (appendix 5).

The fully coupled model is transient and runs using a daily timestep; therefore, the head time-series data measured during the study were included in coupled-model calibration and were processed by using the TSPROC utility (Doherty, 2003; Westenbroek and others, 2012). The TSPROC-processed transient head data were used in the calibration by way of the following summary metrics:

1. Average: This is the average of the selected head time series for the period chosen and typically considered to represent the longer-term condition.

2. Range: This reports the range of all the values in the head time series for the period chosen and represents the system dynamics around the average condition.

3. Time-series difference: This reports the difference between the current value and the previous value in a time series and represents a "moving" drawdown that reflects the temporal dynamics of the time series.

Because the observed head data were measured at a higher frequency than the daily timestep used in the coupled model, the observed data were summarized into daily average values before differencing. Targets derived from the streamflow time-series data were directly ported from the PRMS-only calibration. 


\section{Simulation of Streamflow, Groundwater, and Stream Temperature in the Black Earth Creek Watershed}

Because forward run times were long, all parameters that varied during the calibration of the uncoupled models could not be evaluated in the fully coupled model calibration. The final fully coupled model varied only a subset of all possible model parameters (tables 3-5 and 3-6). The resulting 201 parameters estimated during the fully coupled calibration focused on (1) those parameters not specified in the steady-state MODFLOW-only calibration (for example, aquifer storage, unsaturated zone parameter SURFDEP), (2) those important for simulating the interface between the MODFLOW-only and PRMS-only models, and (3) those considered useful for calibration of coupled models (Jensen-Haise

Table 3-5. Precipitation-Runoff Modeling System (PRMS) parameter types estimated during calibration of the fully coupled GSFLOW model.

[HRU, hydrologic response unit; --, no data]

\begin{tabular}{|c|c|c|c|c|c|c|c|}
\hline \multirow{2}{*}{ Name } & \multirow{2}{*}{ Description } & \multicolumn{3}{|c|}{ Model-suggested values } & \multicolumn{3}{|c|}{ Calibrated values } \\
\hline & & Default & Minimum & Maximum & Average & Minimum & Maximum \\
\hline \multicolumn{8}{|c|}{ climate_hru_prms module } \\
\hline \multicolumn{8}{|c|}{ soilzone_prms module } \\
\hline sat_threshold & $\begin{array}{l}\text { Soil saturation threshold, } \\
\text { above field-capacity } \\
\text { threshold for each HRU }\end{array}$ & $1.0-13$ & 1.0-3.6 & $8.0-13$ & 6.12 & 1.1 & 13 \\
\hline slowcoef_sq & $\begin{array}{l}\text { Nonlinear gravity-flow } \\
\text { reservoir routing } \\
\text { coefficient for each } \\
\text { HRU }\end{array}$ & $0.06-0.14$ & 0.06 & 0.14 & 0.076 & 0.06 & 0.128 \\
\hline soil_moist_max & $\begin{array}{l}\text { Maximum value of water } \\
\text { for soil zone for each } \\
\text { HRU }\end{array}$ & 3.3-8.2 & $0.418-2.01$ & $3.30-9.18$ & 4.34 & 1.83 & 7.40 \\
\hline ssr2gw_rate & $\begin{array}{l}\text { Coefficient to route water } \\
\text { from subsurface to } \\
\text { groundwater for each } \\
\text { HRU }\end{array}$ & $0.0071-0.436$ & 0.000001 & $0.14-0.478$ & 0.155 & 0.00141 & 0.418 \\
\hline \multicolumn{8}{|c|}{ srunoff_smidx_prms module } \\
\hline smidx_coef & $\begin{array}{l}\text { Coefficient in contributing } \\
\text { area computations for } \\
\text { each HRU }\end{array}$ & $0.000128-0.0279$ & $0.015-0.0001$ & $0.035-0.127$ & 0.012 & 0.0001 & 0.0279 \\
\hline
\end{tabular}


coefficient, saturated $\mathrm{K}_{\mathrm{v}}$ of the unsaturated zone). The fully coupled model calibration used singular value decomposition on 84 base parameters. Of these 84 possible parameters, the information content of the multi-objective function observation data supported approximately 66 linear combinations (singular values) using a typical stability criterion (PEST variable
EIGTHRESH $=5.0 \mathrm{E}-07)$. For the specific yield parameter, the calibrated multiplier in table 3-6 results in a value of 0.14 for unconsolidated sediments and 0.05 for the bedrock. For the specific storage parameter, the calibrated multipler shown in table 3-6 results in a value of $9.259 \times 10^{-6} \mathrm{ft}^{-1}$ for both unconsolidated sediments and bedrock.

Table 3-6. MODFLOW parameter types estimated during calibration of the fully coupled GSFLOW model. Parameter names that represent a single parameter do not display minimum and maximum calibrated values.

[ft/d, foot per day; --, no data; m, meter]

\begin{tabular}{|c|c|c|c|c|c|c|c|}
\hline \multirow{2}{*}{ Name } & \multirow{2}{*}{ Description } & \multirow{2}{*}{$\begin{array}{l}\text { Starting } \\
\text { value }\end{array}$} & \multirow{2}{*}{$\begin{array}{l}\text { Lower } \\
\text { bound }\end{array}$} & \multirow{2}{*}{$\begin{array}{l}\text { Upper } \\
\text { bound }\end{array}$} & \multicolumn{3}{|c|}{ Calibrated values } \\
\hline & & & & & Average & Minimum & Maximum \\
\hline streamkv & $\begin{array}{l}\text { Streambed vertical hydraulic } \\
\text { conductivity (ft/d) }\end{array}$ & 0.081 & 0.01 & 0.01 & 0.1284 & -- & -- \\
\hline IXkhmult & $\begin{array}{l}\text { Multiplier for horizontal } \\
\text { hydraulic conductivity } \\
\text { array, one for each layer } \\
\text { (dimensionless) }\end{array}$ & 0.59-1.10 & 0.00001 & 0.0001 & -- & 0.7190018 & 1.265379 \\
\hline IXkvmult & $\begin{array}{l}\text { Multiplier for vertical } \\
\text { hydraulic conductivity } \\
\text { array, one for each layer } \\
\text { (dimensionless) }\end{array}$ & $0.52-2.03$ & 0.00001 & 0.0001 & -- & 0.4681404 & 2.448969 \\
\hline s_mult & $\begin{array}{l}\text { Multiplier for confined } \\
\text { aquifer storage/specific } \\
\text { storage (dimensionless) }\end{array}$ & 0.33 & 0.01 & 50 & 0.2374090 & -- & -- \\
\hline sy_mult & $\begin{array}{l}\text { Multiplier for unconfined } \\
\text { aquifer storage/specific } \\
\text { yield (dimensionless) }\end{array}$ & 0.90 & 0.01 & 10 & 0.9402462 & -- & -- \\
\hline surfdep & $\begin{array}{l}\text { Land surface depression } \\
\text { variable used to smooth } \\
\text { UZF Package solution (m) }\end{array}$ & 1.37 & 0.01 & 0.0001 & 1.954951 & -- & -- \\
\hline vksat multiplier & $\begin{array}{l}\text { Multiplier applied to } \\
\text { initial saturated vertical } \\
\text { hydraulic conductivity } \\
\text { used by UZF Package } \\
\text { (dimensionless) }\end{array}$ & 0.07 & 0.01 & 0.0001 & 0.0007199 & -- & -- \\
\hline
\end{tabular}




\section{References}

Doherty, John, 2003, Groundwater model calibration using pilot points and regularization: Ground Water, v. 41, no. 2, p. $170-177$.

Doherty, John, 2008, PEST surface water utilities: Brisbane, Australia, Watermark Numerical Computing and University of Idaho, 141 p., accessed September 28, 2011, at http:// www.pesthomepage.org/getfiles.php?file=swutils.pdf.

Doherty, John, 2014a, PEST, Model-independent parameter estimation-User manual (5th ed., with slight additions): Brisbane, Australia, Watermark Numerical Computing.

Doherty, John, 2014b, Addendum to the PEST manual: Brisbane, Australia, Watermark Numerical Computing.

Doherty, J.E., Fienen, M.N., and Hunt, R.J., 2010, Approaches to highly parameterized inversion-Pilot-point theory, guidelines, and research directions: U.S. Geological Survey Scientific Investigations Report 2010-5168, 36 p.

Doherty, John, and Hunt, R.J., 2009, Two statistics for evaluating parameter identifiability and error reduction: Journal of Hydrology, v. 366, p. 119-127, doi: 10.1016/j. jhydrol.2008.12.018.

Doherty, John, and Hunt, R.J., 2010a, Response to comment on "Two statistics for evaluating parameter identifiability and error reduction": Journal of Hydrology, v. 380, p. 489-496, doi:10.1016/j.jhydrol.2009.10.012.

Doherty, J.E., and Hunt, R.J., 2010b, Approaches to highly parameterized inversion-A guide to using PEST for groundwater-model calibration: U.S. Geological Survey Scientific Investigations Report 2010-5169, 60 p.

Farnsworth, R.K., Thompson, E.S., and Peck, E.L., 1982, Evaporation atlas for the contiguous 48 United States: U.S. National Atmospheric and Oceanic Administration Technical Report NWS 33, 26 p., 4 pl.

Hay, L.E., Leavesley, G.H., Clark, M.P., Markstrom, S.L., Viger, R.J., and Umemoto, Makiko, 2006, Step wise, multiple objective calibration of a hydrologic model for a snowmelt dominated basin: Journal of the American Water Resources Association, v. 42, no. 4, p. 877-890.

Hunt, R.J., Doherty, John, and Tonkin, M.J., 2007, Are models too simple? Arguments for increased parameterization: Ground Water, v. 45, no. 3, p. 254-262, doi:10.1111/j.17456584.2007.00316.x.

Hunt, R.J., Doherty, J., and Walker, J.F., 2009, Parameter estimation and coupled groundwater/surface-water models-A PEST approach, in Conference Proceedings from the 1st PEST Conference, November 1-3, 2009, Potomac, Maryland.
Hunt, R.J., Walker, J.F., Selbig, W.R., Westenbroek, S.M, and Regan, R.S., 2013, Simulation of climate-change effects on streamflow, lake water budgets, and stream temperature using GSFLOW and SNTEMP, Trout Lake watershed, Wisconsin: U.S. Geological Survey Scientific Investigations Report 2013-5159, 118 p.

Markstrom, S.L., Niswonger, R.G., Regan, R.S., Prudic, D.E., and Barlow, P.M., 2008, GSFLOW-Coupled GroundWater and Surface-Water Flow Model based on the integration of the Precipitation-Runoff Modeling System (PRMS) and the Modular Ground-Water Flow Model (MODFLOW-2005): U.S. Geological Survey Techniques and Methods, book 6, chap. D1, 240 p.

Markstrom, S.L., Regan, R.S., Hay, L.E., Viger, R.J., Webb, R.M.T., Payn, R.A., and LaFontaine, J.H., 2015, PRMSIV, the Precipitation-Runoff Modeling System, Version 4: U.S. Geological Survey Techniques and Methods, book 6, chap. B7, 158 p., accessed December 1, 2015, at http://pubs. usgs.gov/tm/6b7.

Miller, I., and Freund, J.E., 1977, Probability and statistics for engineers: Englewood Cliffs, N.J., Prentice-Hall, 530 p.

Sloto, R.A., and Crouse, M.Y., 1996, HYSEP-A computer program for streamflow hydrograph separation and analysis: U.S. Geological Survey Water-Resources Investigations Report 96-4040, 46 p.

Tikhonov, A.N., 1963a, Solution of incorrectly formulated problems and the regularization method: Soviet Mathematics Doklady, v. 4, p. 1035-1038.

Tikhonov, A.N., 1963b, Regularization of incorrectly posed problems: Soviet Mathematics Doklady, v. 4, p. 1624-1637.

Walker, J.F., Hunt, R.J., Doherty, J., and Hay, L., 2009, Processing time-series data to calibrate a surface-water model in small headwater watersheds, in Conference Proceedings from the 1st PEST Conference, November 1-3, 2009, Potomac, Maryland.

Westenbroek, S.M., Doherty, J.E., Walker, J.F., Kelson, V.A., Hunt, R.J., and Cera, T.B., 2012, Approaches in highly parameterized inversion-TSPROC, A general time-series processor to assist in model calibration and result summarization: U.S. Geological Survey Techniques and Methods, book 7, chap. C7, 73 p. 


\section{Appendix 4. Temperature Model Construction and Calibration}

\section{Introduction}

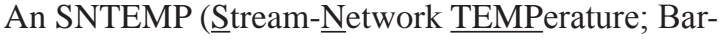
tholow, 1989; 1991) stream-temperature model was developed to predict daily mean and maximum stream temperatures at select locations along the main stem and tributaries of Black Earth Creek. This section describes the model framework, data collection and synthesis, and calibration/verification procedures for the Black Earth Creek stream-temperature model.

\section{Model Framework}

The instream water temperature model SNTEMP, developed and supported by the U.S Fish and Wildlife Service, was selected to predict stream temperatures in Black Earth Creek and its tributaries. A modified version of SNTEMP called Stream Temperature for Windows (http://www.normandeau. $\mathrm{com} /$ pages/services/instream_flow_streamtemp.asp) provided a graphical user interface to simplify data entry and export. SNTEMP is a steady-state, one-dimensional (horizontal) heat transport model that predicts daily mean and maximum temperatures as a function of stream distance and environmental heat flux (Bartholow, 1991). A heat transport equation describes the downstream movement of heat energy in the water and actual exchange of heat energy between the water and its surrounding physical environment (Theurer and others, 1984). Net heat flux is calculated by parameter inputs describing the meteorological, hydrological, stream geometry, and shade setting for a dendritic network of main stem and tributary stream segments that constitute Black Earth Creek.

\section{Model Input and Calibration/Verification Data}

SNTEMP consists of several component modules that describe the physical setting of the study area. These modules can be broken into three broad categories: stream geometry, meteorology, and hydrology. SNTEMP assumes that all input data, including meteorological and hydrological variables, can be represented by 24-hour averages (Bartholow, 1991). Many of the model input parameters were taken from published, historical data sources. Environmental sensors were deployed to measure weather parameters within the watershed and stream temperature at strategic locations in the stream network. The calibration period was May-September 2005. The locations of the weather and temperature sensors, where the tan area represents the topographic contributing area to Black Earth Creek, are shown in figure 4-1.

Black Earth Creek, including its tributaries, was split into 32 stream segments. Each segment is characterized as having uniform width, groundwater accretion rates, and relatively homogeneous topographic and riparian vegetation conditions with major transitions in between. The farthest upstream segment began west of the town of Middleton at Low Road and terminated at Bridge Street in the town of Mazomanie. Each stream segment requires a physical description of stream geometry, hydrology, and shading variables. Meteorological variables are more global in nature and were applied to all stream segments universally. The linear structure and conceptual model of Black Earth Creek and its tributaries used in the SNTEMP model are shown in figure 4-2. This section documents the sources of input and calibration/verification data.

\section{Stream Geometry}

Stream geometry data consist of the network layout of the main stem and all tributaries, site elevations, stream widths, Manning's n values, and shade estimates. Stream widths were measured at select locations in the field and then supplemented using spatially rectified aerial photography for areas that were difficult to reach. SNTEMP allows the user to describe stream width as a function of flow. Because the amount of information required to develop this relationship was beyond the scope of this project, it was assumed the width of the stream segment remained constant and did not change with increasing flow. The thermal gradient applied to each reach made use of default values. Manning's n values were estimated based on reported ranges for natural channels (Gupta, 1989). Due to the high degree of uncertainty associated with selecting an appropriate Manning’s n value, each stream segment initially received the same value. Adjustments to Manning's n were made during model calibration. Elevation, latitude, longitude, and river kilometer locations were acquired through a global positioning system (GPS). Stream azimuth was determined using topographic maps. Stream geometry parameters for each stream reach described in the Black Earth Creek network model are listed in table 4-1.

\section{Stream Shading}

Topographic angle, vegetation offset from stream bank, crown width, shade density, and riparian vegetation height were measured throughout the summer of 2005 using methods described in Bartholow (1989) and Fitzpatrick and others (1998). Measurements were taken at several random locations on the left and right banks of each stream segment and then were averaged to provide a single value for each stream segment bank.

In areas that were inaccessible, shading values were estimated using spatially rectified aerial photographs. Stream shading parameters for each stream reach described in the Black Earth Creek stream network model are listed in table 4-2. 


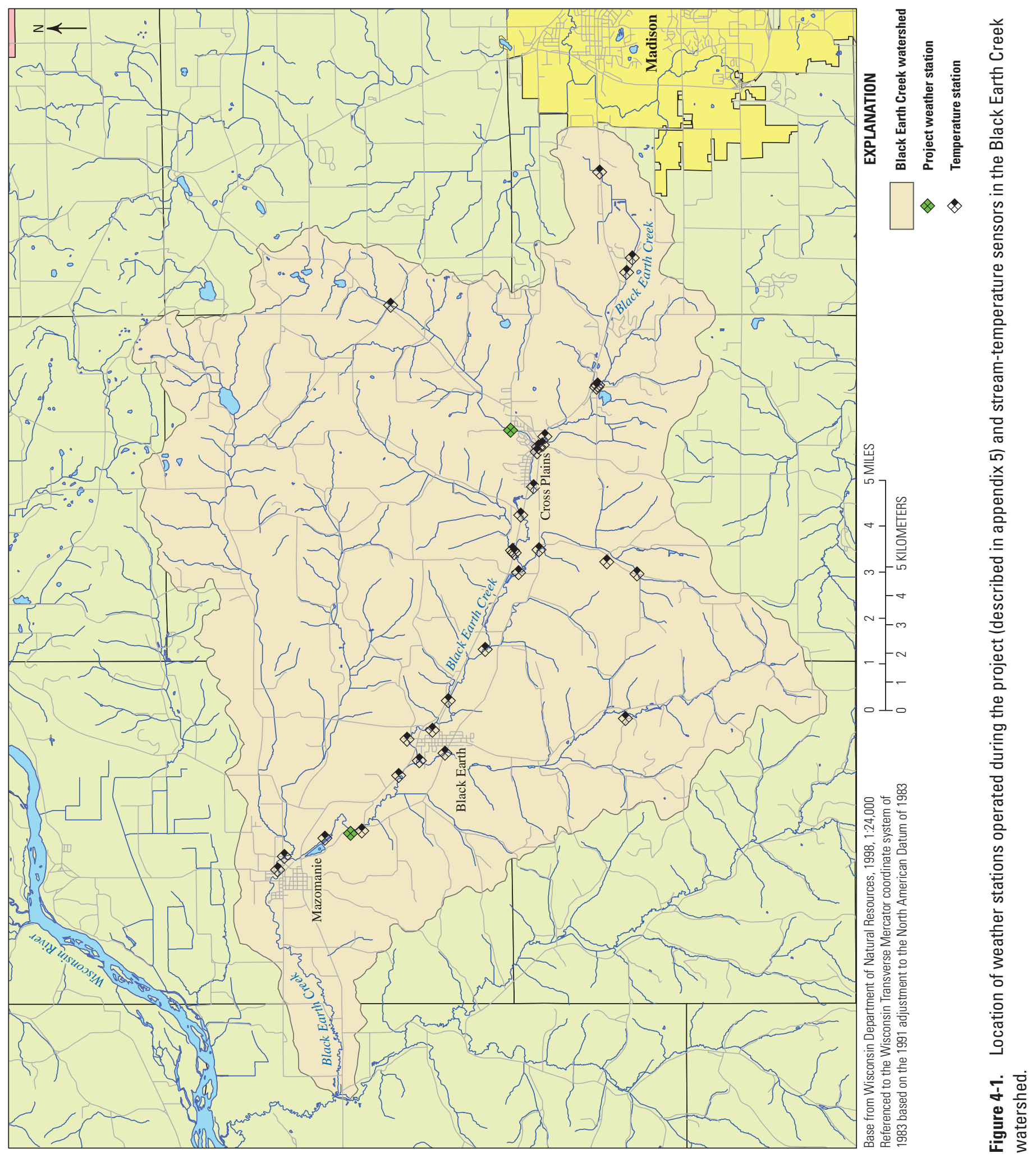




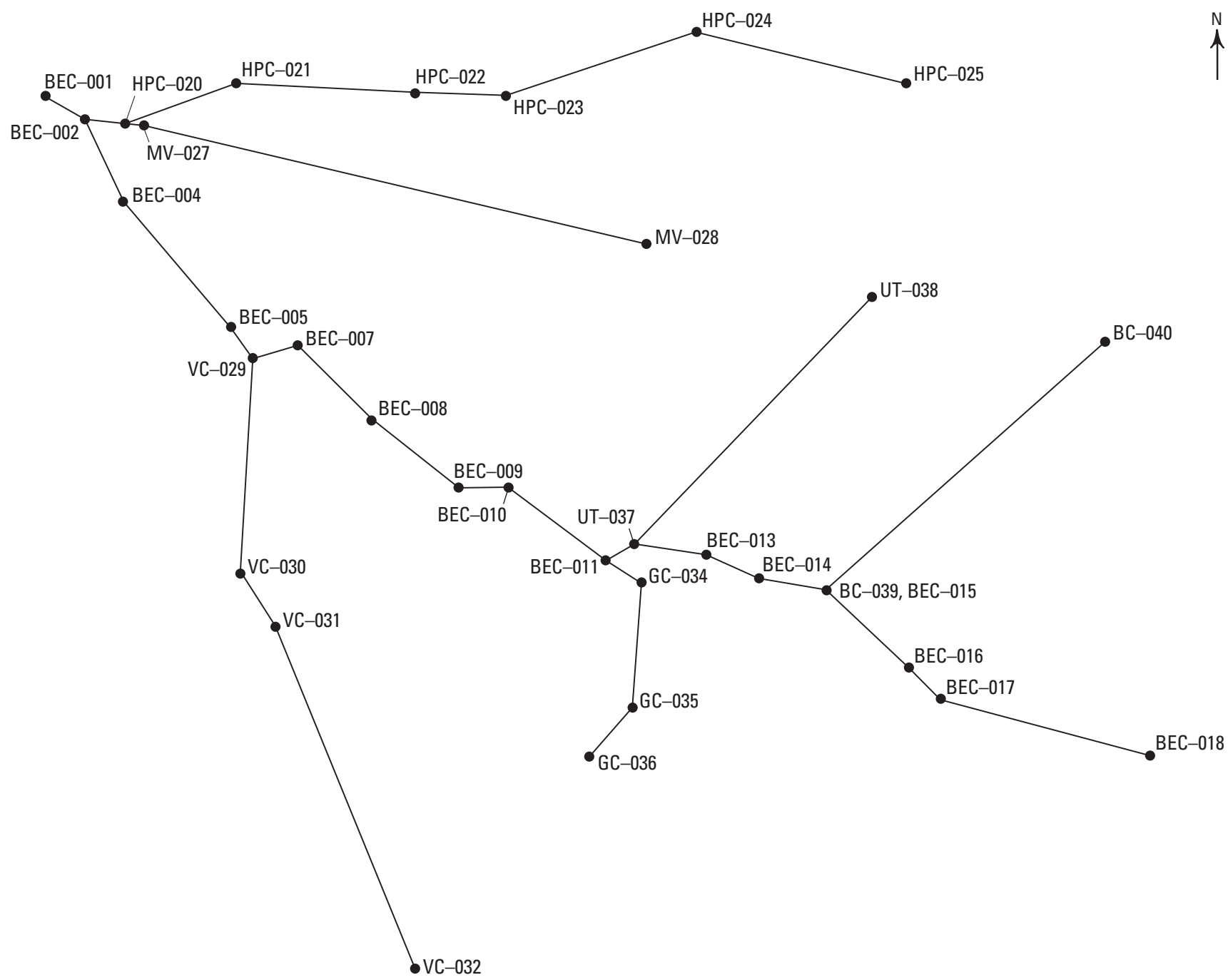

Figure 4-2. Conceptual model illustrating linear structure of stream network used in SNTEMP [BEC, Black Earth Creek; HPC, Halfway Prairie Creek; MV, Marsh Valley Creek; VC, Vermont Creek; UT, Unnamed tributary; GC, Garfoot Creek; $\mathrm{BC}$, Brewery Creek]. 
Table 4-1. Stream geometry characteristics for stream reaches described in SNTEMP.

[Longitude is not reported because only latitude is required for calculation of solar radiation drivers. deg, degree; $\mathrm{m}$, meter]

\begin{tabular}{|c|c|c|c|c|c|c|c|c|}
\hline \multirow{2}{*}{ Stream name } & \multicolumn{2}{|c|}{ Stream reach } & \multirow[b]{2}{*}{ Degrees } & \multicolumn{2}{|l|}{ Latitude } & \multirow{2}{*}{$\begin{array}{l}\text { Azimuth } \\
\text { (deg) }\end{array}$} & \multirow{2}{*}{ Manning's n } & \multirow{2}{*}{ Width (m) } \\
\hline & From & To & & Minutes & Seconds & & & \\
\hline Black Earth Creek & BEC-018 & BEC-017 & 43 & 9 & 14 & 285.9 & 0.035 & 2.00 \\
\hline Black Earth Creek & BEC-017 & BEC-016 & 43 & 9 & 14 & 302.2 & 0.035 & 2.00 \\
\hline Black Earth Creek & BEC-016 & BEC-015 & 43 & 9 & 14 & 324.2 & 0.035 & 2.00 \\
\hline Black Earth Creek & BEC-015 & BEC-014 & 43 & 8 & 2 & 280.4 & 0.035 & 7.00 \\
\hline Black Earth Creek & BEC-014 & BEC-013 & 43 & 7 & 31 & 296.3 & 0.035 & 6.00 \\
\hline Black Earth Creek & BEC-013 & BEC-012 & 43 & 7 & 15 & 278.2 & 0.035 & 6.10 \\
\hline Black Earth Creek & BEC-012 & BEC-011 & 43 & 6 & 50 & 237.7 & 0.035 & 9.78 \\
\hline Black Earth Creek & BEC-011 & BEC-010 & 43 & 8 & 50 & 308.5 & 0.035 & 10.20 \\
\hline Black Earth Creek & BEC-010 & BEC-009 & 43 & 10 & 56 & 269.9 & 0.035 & 10.20 \\
\hline Black Earth Creek & BEC-009 & BEC-008 & 43 & 11 & 11 & 309.5 & 0.035 & 21.68 \\
\hline Black Earth Creek & BEC-008 & BEC-007 & 43 & 11 & 1 & 317.4 & 0.035 & 21.68 \\
\hline Black Earth Creek & BEC-007 & BEC-006 & 43 & 9 & 34 & 251.9 & 0.035 & 10.45 \\
\hline Black Earth Creek & BEC-006 & BEC-005 & 43 & 6 & 58 & 325.7 & 0.035 & 9.66 \\
\hline Black Earth Creek & BEC-005 & BEC-004 & 43 & 6 & 3 & 321.6 & 0.035 & 20.00 \\
\hline Black Earth Creek & BEC-004 & BEC-002 & 43 & 6 & 55 & 336.0 & 0.035 & 20.00 \\
\hline Black Earth Creek & BEC-002 & BEC-001 & 43 & 8 & 2 & 300.8 & 0.035 & 20.00 \\
\hline Halfway Prairie Creek & HPC-025 & HPC-024 & 43 & 10 & 35 & 284.4 & 0.035 & 1.50 \\
\hline Halfway Prairie Creek & HPC-024 & HPC-023 & 43 & 10 & 34 & 250.4 & 0.035 & 3.00 \\
\hline Halfway Prairie Creek & HPC-023 & HPC-022 & 43 & 10 & 9 & 271.9 & 0.035 & 3.00 \\
\hline Halfway Prairie Creek & HPC-022 & HPC-021 & 43 & 8 & 19 & 273.2 & 0.035 & 3.00 \\
\hline Halfway Prairie Creek & HPC-021 & HPC-020 & 43 & 6 & 58 & 248.9 & 0.035 & 4.00 \\
\hline Halfway Prairie Creek & HPC-020 & MV-019 & 43 & 6 & 53 & 277.8 & 0.035 & 5.00 \\
\hline Marsh Valley Creek & MV-028 & MV-027 & 43 & 5 & 57 & 284.1 & 0.035 & 3.50 \\
\hline Marsh Valley Creek & MV-027 & MV-026 & 43 & 5 & 25 & 271.9 & 0.035 & 3.51 \\
\hline Vermont Creek & VC-032 & $\mathrm{VC}-031$ & 43 & 8 & 8 & 339.0 & 0.035 & 3.44 \\
\hline Vermont Creek & $\mathrm{VC}-031$ & $\mathrm{VC}-030$ & 43 & 11 & 13 & 329.7 & 0.035 & 3.81 \\
\hline Vermont Creek & VC-030 & BEC-029 & 43 & 9 & 7 & 3.0 & 0.035 & 2.00 \\
\hline Garfoot Creek & GC-036 & GC-035 & 43 & 7 & 33 & 40.1 & 0.035 & 1.50 \\
\hline Garfoot Creek & GC-035 & GC-034 & 43 & 7 & 33 & 3.8 & 0.035 & 2.00 \\
\hline Garfoot Creek & GC-034 & BEC-033 & 43 & 6 & 25 & 303.8 & 0.035 & 2.50 \\
\hline Unnamed tributary & UT-038 & BEC-037 & 43 & 6 & 50 & 222.1 & 0.035 & 1.00 \\
\hline Brewery Creek & BC-040 & BEC-039 & 43 & 9 & 44 & 226.4 & 0.035 & 3.00 \\
\hline
\end{tabular}




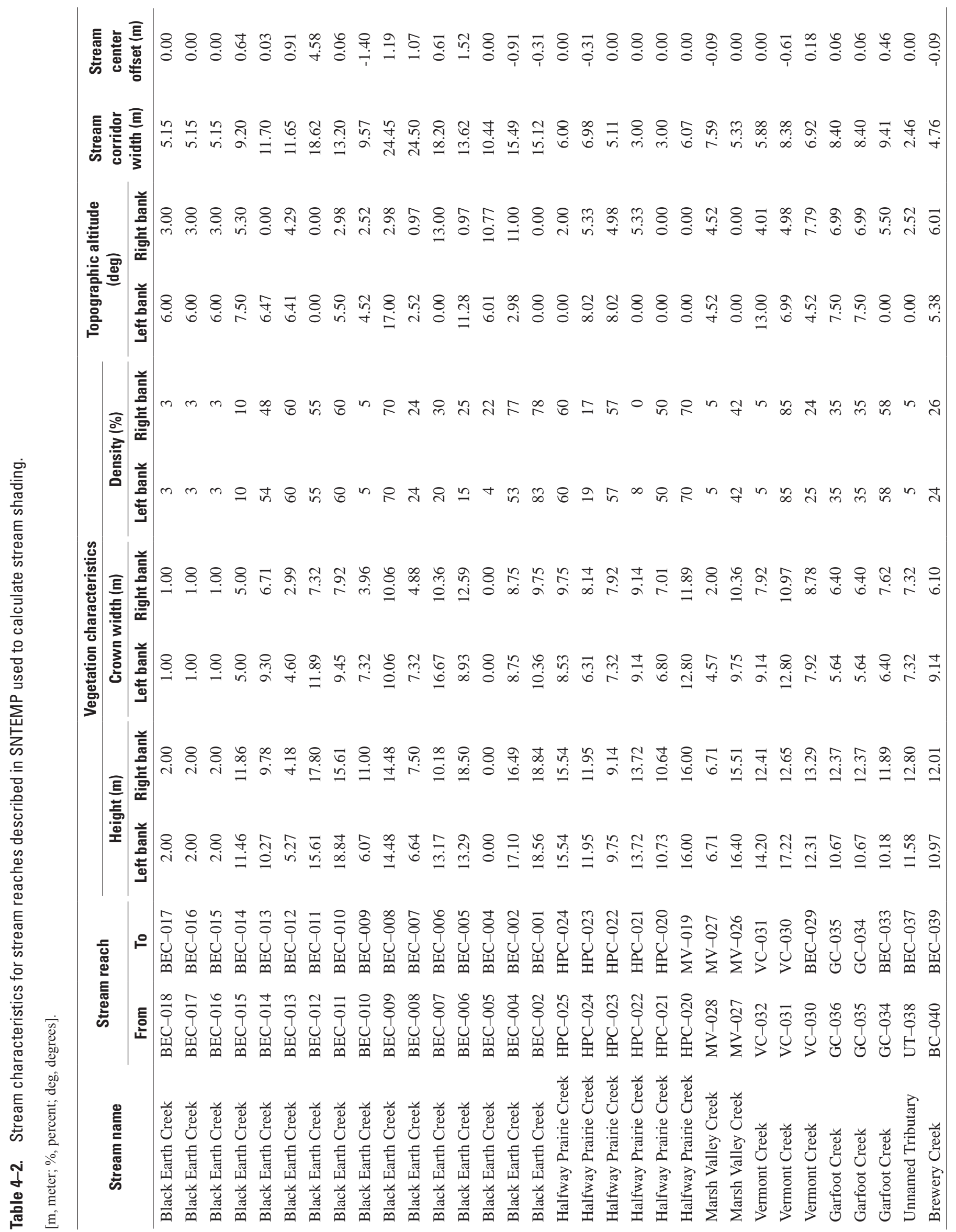




\section{Meteorology}

Meteorological data consist of solar radiation, air temperature, relative humidity, wind speed, and cloud cover. These variables are used by SNTEMP to calculate solar radiation. The user can also directly enter solar radiation if data are available. Two weather stations were established within the Black Earth Creek watershed (fig. 4-1). Both stations measured air temperature, solar radiation, precipitation, wind speed, and relative humidity. SNTEMP uses only one set of meteorological data; therefore, data from both locations were synthesized into a single daily mean value and applied to the entire watershed. Cloud cover was estimated using a calculated percent possible sunshine for Madison, Wisconsin (http:// aa.usno.navy.mil). Dust coefficients and ground reflectivity were taken from published values described in Tennessee Valley Authority (1972). Dust coefficients were a constant value of 0.06 based on average optical air mass values for Madison, Wisconsin, during summer months. A ground reflectivity value of 0.24 was used for all stream segments to an average vegetative cover of leaves. Although point solar radiation data were available, better agreement between predicted and observed stream temperatures was achieved using values calculated within SNTEMP. Default values were used for all other meteorological variables required by SNTEMP.

\section{Hydrology}

Hydrologic data consist of stream discharge and water temperatures from surface-water and groundwater sources. SNTEMP requires upstream discharge and temperature data for each modeled stream segment, except for zero-flow headwaters. Daily mean discharge data used in the SNTEMP model were estimated using a calibrated version of the GSFLOW model described in this report. The starting point of each headwater segment of each tributary was assumed to be zeroflow headwaters and thus did not require stream temperatures for model execution. SNTEMP allows the user to assume a zero-flow headwater discharge, which disregards any associated recorded temperature data because there cannot be any water temperature if there is no water discharge. SNTEMP cannot simulate changes in stream temperature from nonpoint sources of runoff unless treated as point sources. This level of detail was beyond the scope of this project. To minimize large differences between measured and simulated daily mean temperature as a result of nonpoint runoff, daily precipitation depths greater than 0.5 inches were removed from the calibration period, which was a total of 11 days.

Instantaneous stream temperature was recorded at 15-minute intervals in 28 locations throughout the drainage network (fig. 4-2). Daily mean temperatures were then computed from the instantaneous values and used as calibration targets for SNTEMP predictions. The locations of each streamtemperature recorder were selected to better characterize areas that typically result in longitudinal changes in stream temperature such as confluences with tributaries, point sources, known groundwater seeps, and major transitions in riparian shading. Each recorder was placed in the stream channel using methods described by Bartholow (1989). An attempt was made to capture stream temperature near all tributary headwaters; however, in most cases there was insufficient discharge to cover the temperature sensor resulting in measurements of air temperature rather than water temperature.

Groundwater temperature was based on measurements from monitoring wells located within the Black Earth Creek watershed (U.S. Geological Survey, unpub. data, 2005). Mean groundwater temperatures during the period of model calibration (May-September) showed little variation from a constant 10 degrees Celsius in 2005 and 2013 and were consistent to those reported by Novitzki (1973). The daily mean groundwater temperature was, therefore, assumed to remain constant and was universally applied to each stream segment in the model.

\section{References}

Bartholow, J.M., 1989, Stream temperature investigationsField and analytical methods: U.S. Fish and Wildlife Service Instream Flow Information Paper No. 13, Biological Report 89(17), 139 p.

Bartholow, J.M., 1991, A modeling assessment of the thermal regime for an urban sport fishery: Environmental Management, v. 15, no. 6, p. 833-845.

Fitzpatrick, F.A., Waite, I.R., D’Arconte, P.J., Meador, M.R., Maupin, M.A., and Gurtz, M.E., 1998, Revised methods for characterizing stream habitat in the National Water-Quality Assessment Program: U.S. Geological Survey WaterResources Investigations Report 98-4052, 67 p.

Gupta, R.S., 1989, Hydrology and hydraulic systems: Englewood Cliffs, N.J., Prentice Hall.

Novitzki, R.P., 1973, Improvement of trout streams in Wisconsin by augmenting low flows with ground water: U.S. Geological Survey Water-Supply Paper 2017, 52 p.

Tennessee Valley Authority, 1972, Heat and mass transfer between a water surface and the atmosphere: Norris, Tenn., Water Resources Research Laboratory Report 14, 166 p.

Theurer, F.D., Voos, K.A., and Miller, W.J., 1984, Instream water temperature model: U.S. Fish and Wildlife Service Instream Flow Information Paper 16, FWS/OBS-85/15 [variously paged]. 


\section{Appendix 5. Field Data Collection (2004-2005)}

\section{Introduction}

As a result of various existing and project related datacollection efforts, extensive datasets were available for model calibration. These datasets are described below.

\section{Surface Water Discharge}

In addition to the long-term gage operating just east of the Village of Black Earth (Black Earth Creek near Black Earth, station 05406500), 10 other streamflow locations were monitored during October 2004 through September 2005 (table 5-1). Data collected at these locations were published by Waschbusch and others (2005) and can be accessed at http://wi.water.usgs.gov/data/index.html.

\section{Precipitation Measurements}

In addition to the existing weather stations in the watershed area, two additional precipitation gages were installed during the October 2004 through September 2005 (appendix 4, fig. 4-1; table 5-2); data collected at these locations were published by Waschbusch and others (2005) can be accessed at http://wi.water.usgs.gov/data/index.html.

\section{Surface-Water Temperature}

Surface water temperature was collected at 28 sites (appendix 4, fig. 4-1) and is described in appendix 4.

\section{Seepage Runs}

In addition to time-series streamflow monitoring, two synoptic surveys were performed during base flow conditions, referred to as "seepage runs," at 28 locations in the basin (appendix 1, fig. 1-1) in February and July 2005 (tables 5-1 through 5-4). Initial modeling (appendix 1) was used to identify locations within the basin where data collection could enhance model calibration. The period of the data collection coincided with a relatively dry period compared to the longterm average (fig. 9A, main report) and results are published by Waschbusch and others (2005).

Table 5-1. Streamflow monitoring locations.

[No., number]

\begin{tabular}{|c|c|c|c|c|}
\hline $\begin{array}{l}\text { Station } \\
\text { number }\end{array}$ & Station name & $\begin{array}{c}\text { Latitude } \\
\text { (degrees, minutes, } \\
\text { seconds) }\end{array}$ & $\begin{array}{c}\text { Longitude } \\
\text { (degrees, minutes, } \\
\text { seconds) }\end{array}$ & $\begin{array}{l}\text { Drainage area } \\
\text { (square miles) }\end{array}$ \\
\hline 05406450 & Black Earth Creek near Cross Plains & $43^{\circ} 05^{\prime} 16^{\prime \prime}$ & $-89^{\circ} 34^{\prime} 35^{\prime \prime}$ & 3.32 \\
\hline 054064509 & Black Earth Creek Low Flow Site No. 3 near Cross Plains & $43^{\circ} 05^{\prime} 49^{\prime \prime}$ & $-89^{\circ} 37^{\prime} 33^{\prime \prime}$ & 9.02 \\
\hline 05406460 & Black Earth Creek at Cross Plains & $43^{\circ} 06^{\prime} 40^{\prime \prime}$ & $-89^{\circ} 38^{\prime} 45^{\prime \prime}$ & 12.8 \\
\hline 05406465 & Brewery Creek at County Highway K at Cross Plains & $43^{\circ} 08^{\prime} 56^{\prime \prime}$ & $-89^{\circ} 35^{\prime} 50^{\prime \prime}$ & 3.26 \\
\hline 054064775 & Black Earth Creek Tributary, at County Highway KP & $43^{\circ} 06^{\prime} 43^{\prime \prime}$ & $-89^{\circ} 39^{\prime} 26^{\prime \prime}$ & 0.2 \\
\hline 054064895 & Garfoot Creek at Braun Road near Cross Plains & $43^{\circ} 05^{\prime} 13^{\prime \prime}$ & $-89^{\circ} 41^{\prime} 25^{\prime \prime}$ & 1.8 \\
\hline 054064915 & Garfoot Creek at County Highway KP near Cross Plains & $43^{\circ} 06^{\prime} 42^{\prime \prime}$ & $-89^{\circ} 40^{\prime} 54^{\prime \prime}$ & 5.86 \\
\hline 05406500 & Black Earth Creek at Black Earth & $43^{\circ} 08^{\prime} 03^{\prime \prime}$ & $-89^{\circ} 43^{\prime} 56^{\prime \prime}$ & 45.6 \\
\hline
\end{tabular}

Table 5-2. Precipitation monitoring locations.

\begin{tabular}{llcc}
\hline Station number & Station name & $\begin{array}{c}\text { Latitude } \\
\text { (degrees, minutes, seconds) }\end{array}$ & $\begin{array}{c}\text { Longitude } \\
\text { (degrees, minutes, seconds) }\end{array}$ \\
\hline 054064895 & Garfoot Creek at Braun Road near Cross Plains & $43^{\circ} 05^{\prime} 13^{\prime \prime}$ & $-89^{\circ} 41^{\prime} 25^{\prime \prime}$ \\
05406465 & Brewery Creek at County Highway K at Cross Plains & $43^{\circ} 08^{\prime} 56^{\prime \prime}$ & $-89^{\circ} 35^{\prime} 50^{\prime \prime}$ \\
\hline
\end{tabular}




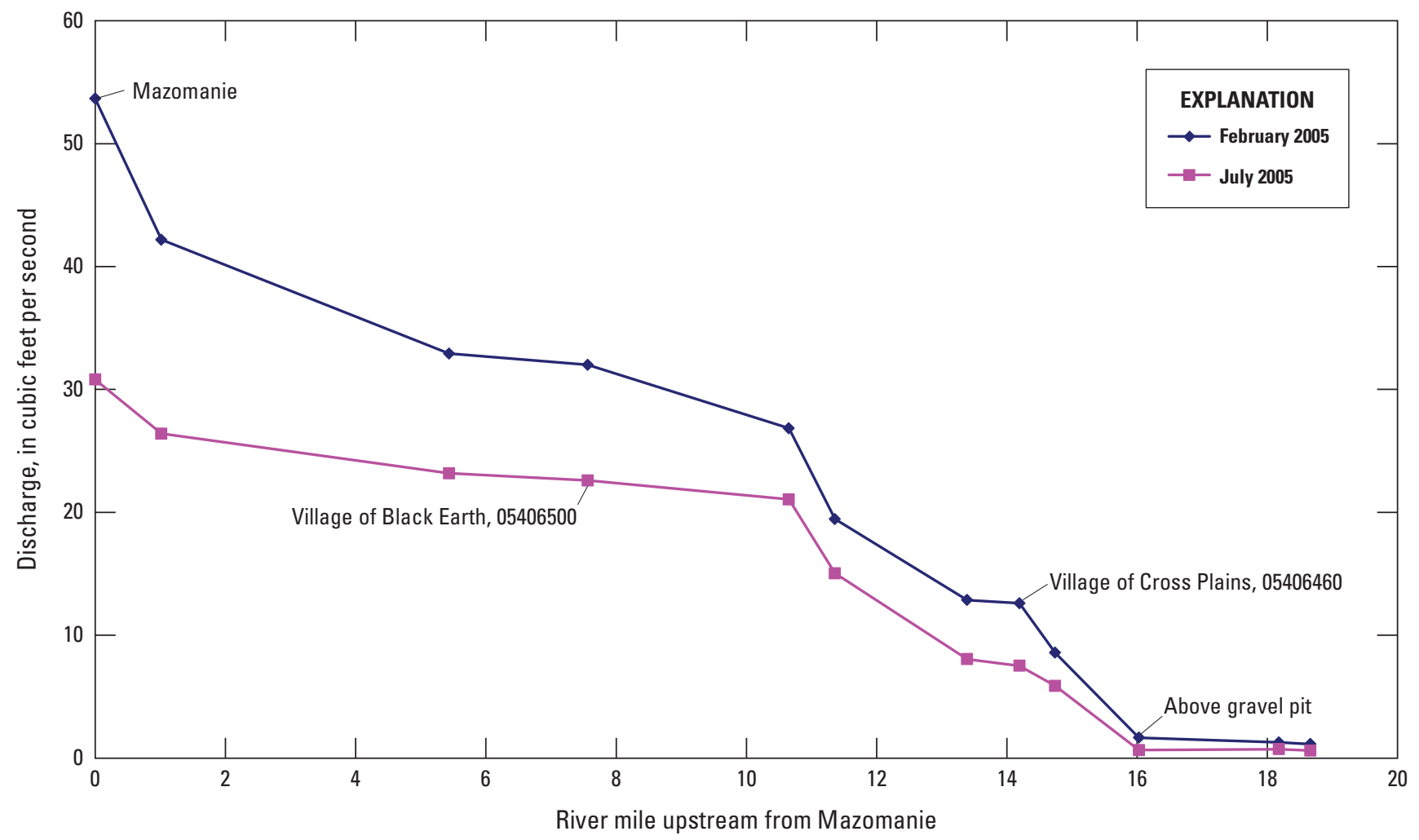

Figure 5-1. Seepage run results and stream discharge along Black Earth Creek stream system.

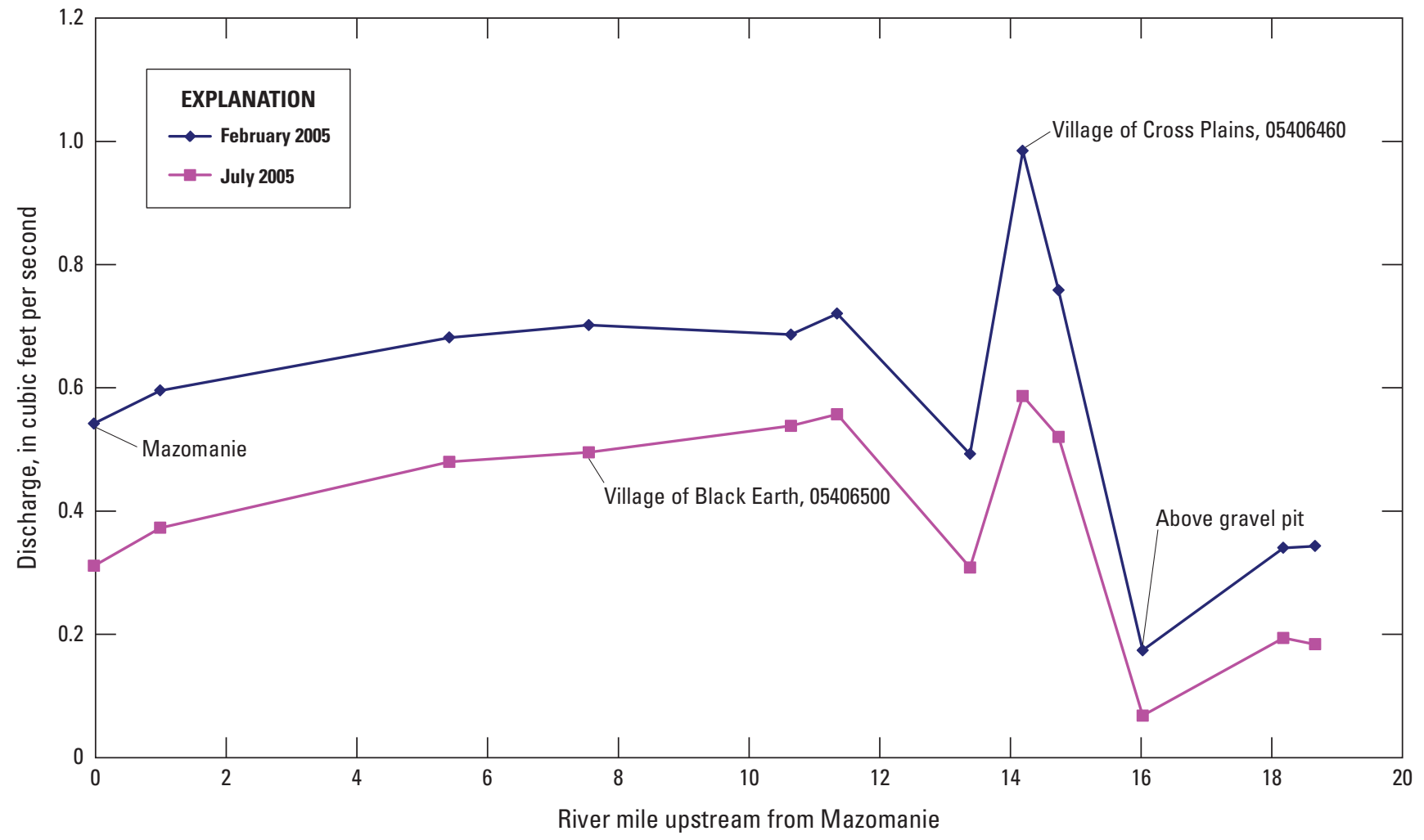

Figure 5-2. Seepage run results and stream discharge normalized by upstream watershed area. 


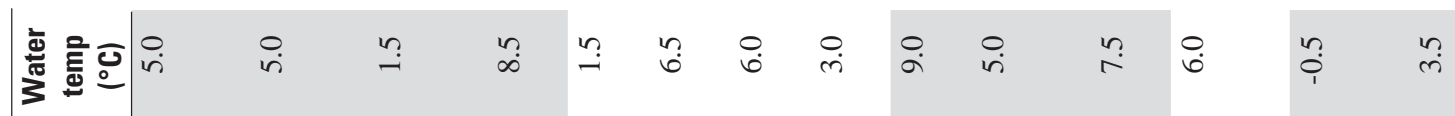

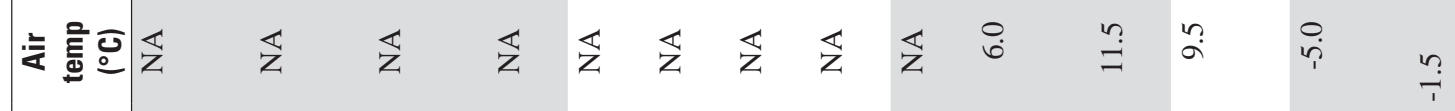

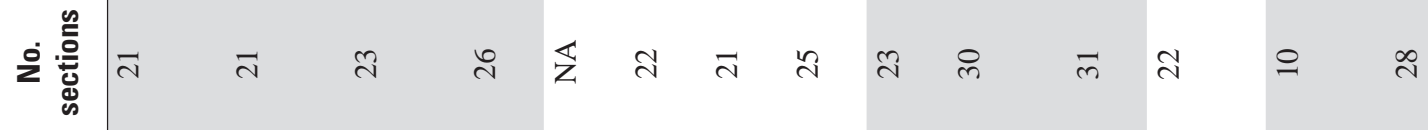

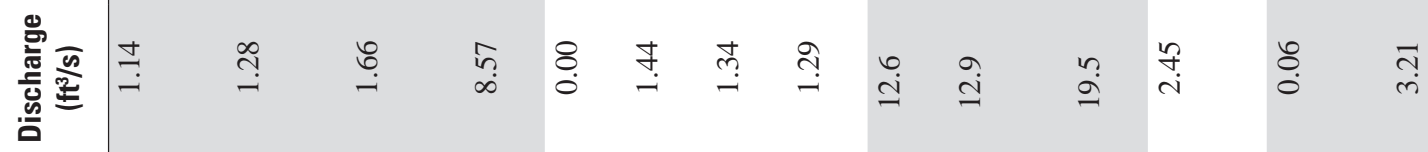

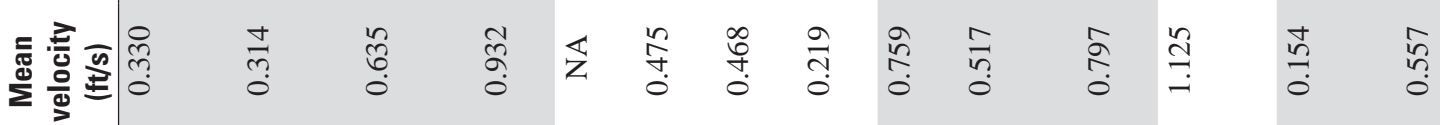

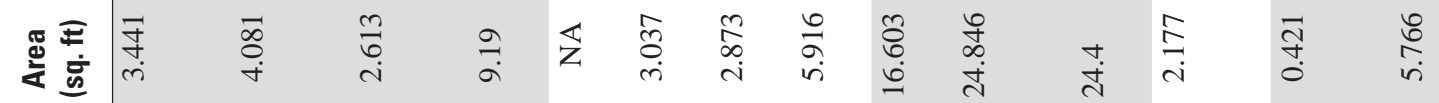

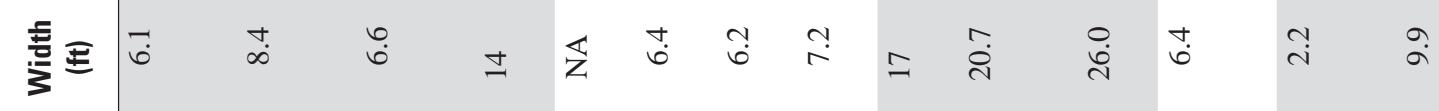

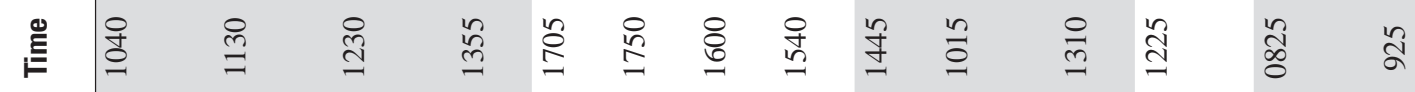

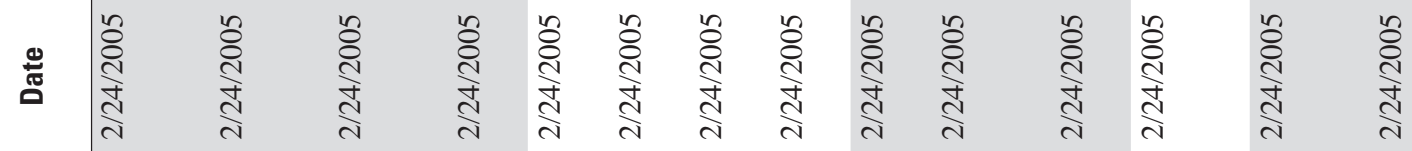

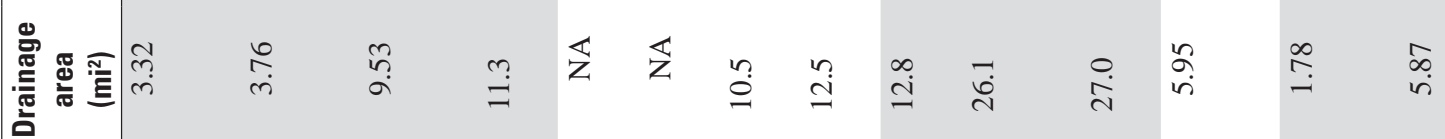

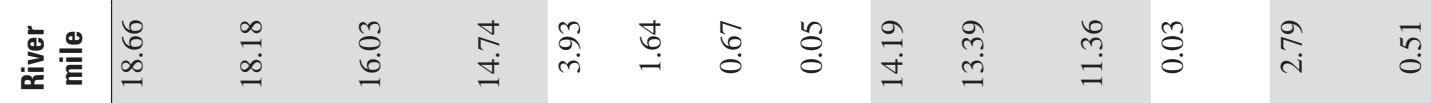

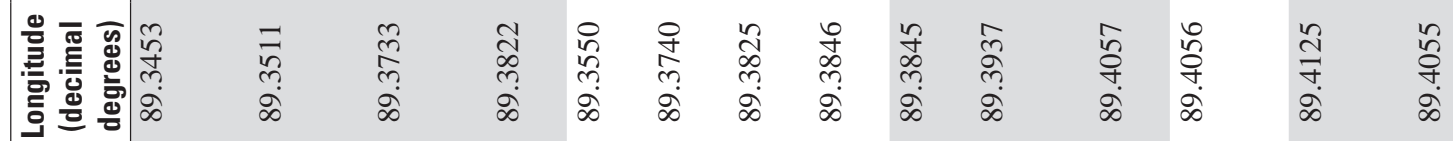

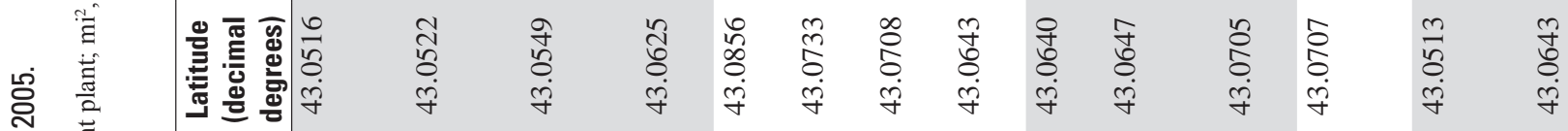

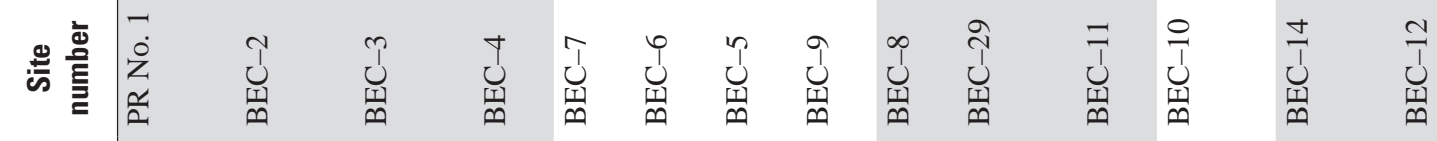

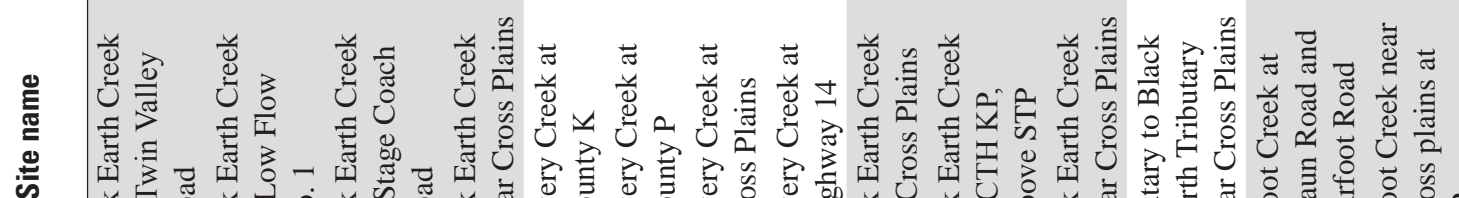

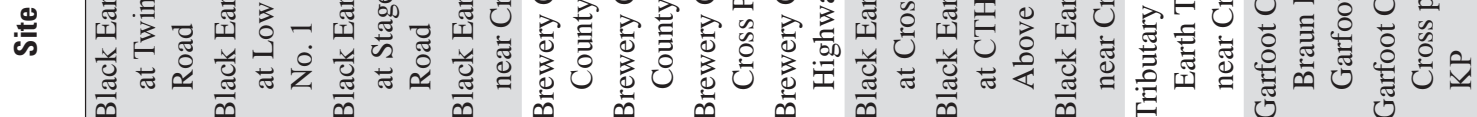




\begin{tabular}{|c|c|c|c|c|c|c|c|c|c|c|c|c|c|c|c|c|}
\hline 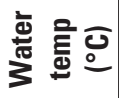 & 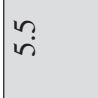 & $\overleftrightarrow{z}$ & $\ddot{\theta}$ & $\stackrel{\circ}{+}$ & $\stackrel{\llcorner}{n}$ & นึ & 우 & 루 & ํำ & 우 & بִ & $\stackrel{\leftrightarrow}{i}$ & $\stackrel{\llcorner}{\sim}$ & $\stackrel{\circ}{\dot{m}}$ & $\stackrel{\llcorner}{i}$ & $\stackrel{\circ}{\circ}$ \\
\hline 安言导 & $\ddot{0}$ & $\overleftarrow{z}$ & ֻุ & $\stackrel{\circ}{+}$ & ㅇ. & $\stackrel{\text { Lִ }}{i}$ & ำ & & $\stackrel{0}{0}$ & $\because$ & $\overleftrightarrow{z}$ & $\stackrel{\circ}{+}$ & $\stackrel{1}{0}$ & $\stackrel{\circ}{\dot{m}}$ & $\stackrel{L}{n}$ & 艺 \\
\hline $2 \stackrel{0}{2}$ & $\tilde{\curvearrowright}$ & 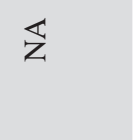 & $\stackrel{\text { N }}{ }$ & $\tilde{m}$ & $\stackrel{m}{m}$ & $\vec{m}$ & নి & $\stackrel{\nu}{v}$ & $\stackrel{\text { }}{ }$ & ஜి & $\stackrel{\varphi}{-1}$ & $\mathscr{N}$ & $\vec{\sim}$ & $\stackrel{ \pm}{\sim}$ & $\stackrel{\sim}{\sim}$ & $\stackrel{\sim}{\sim}$ \\
\hline 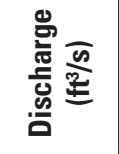 & $\begin{array}{l}\infty \\
\dot{\omega} \\
\sim\end{array}$ & $\begin{array}{l}\text { 오 } \\
\text { ஸे }\end{array}$ & $\begin{array}{l}\mathscr{0} \\
\ddot{n}\end{array}$ & 号 & $\begin{array}{l}\text { on } \\
\text { in }\end{array}$ & $\begin{array}{l}\text { iे } \\
\text { }\end{array}$ & 犬ี & $\hat{\text { ฒે }}$ & $\begin{array}{l}\mathscr{D} \\
\ddot{n}\end{array}$ & $\begin{array}{l}\stackrel{L}{\sim} \\
\text { ம் }\end{array}$ & 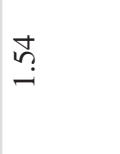 & $\begin{array}{l}\infty \\
\infty \\
\dot{1}\end{array}$ & $\begin{array}{l}\hat{0} \\
\dot{0}\end{array}$ & ले & 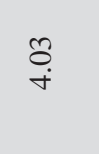 & $\stackrel{\bullet}{\check{r}}$ \\
\hline 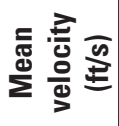 & $\begin{array}{l}\overrightarrow{\tilde{\sigma}} \\
\stackrel{-}{-}\end{array}$ & $\overleftrightarrow{z}$ & $\stackrel{ }{\exists}$ & 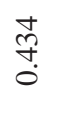 & 苞 & $\stackrel{m}{\oplus}=$ & 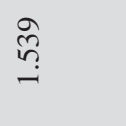 & $\stackrel{\mathscr{m}}{\stackrel{\sim}{\sim}}$ & જิ & $\begin{array}{c}\overrightarrow{\tilde{m}} \\
\text { } \\
0\end{array}$ & $\begin{array}{l}\text { Oे } \\
\text { بn } \\
0\end{array}$ & 早 & 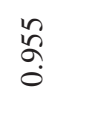 & $\begin{array}{c}\infty \\
\infty \\
i \\
0 \\
0\end{array}$ & $\begin{array}{l}\infty \\
\stackrel{\infty}{0} \\
0\end{array}$ & $\begin{array}{l}\stackrel{0}{0} \\
\infty \\
0\end{array}$ \\
\hline 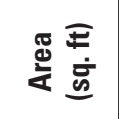 & 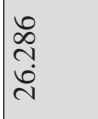 & $\overleftarrow{z}$ & $\begin{array}{c}\infty \\
\substack{+\infty \\
\dot{m}}\end{array}$ & $\begin{array}{l}\stackrel{N}{\hat{b}} \\
\stackrel{\Theta}{-}\end{array}$ & $\begin{array}{l}\text { Nิ } \\
\stackrel{\overbrace{}}{=} \\
=\end{array}$ & $\begin{array}{l}\text { } \\
\text { ठุ. } \\
\ddot{2}\end{array}$ & 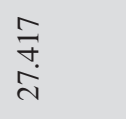 & $\stackrel{\text { nִ }}{\hat{m}}$ & $\underset{\stackrel{L}{N}}{\stackrel{\sim}{*}}$ & $\begin{array}{l}\infty \\
\infty \\
\stackrel{1}{\sim}\end{array}$ & $\begin{array}{l}\hat{\emptyset} \\
\ddot{\theta}\end{array}$ & $\begin{array}{l}10 \\
\stackrel{1}{0} \\
0 \\
0 \\
-1\end{array}$ & $\begin{array}{l}\infty \\
\stackrel{\infty}{n} \\
\tilde{\omega}\end{array}$ & $\underset{\substack{t \\
\text { in } \\
\text { in }}}{ }$ & 点 & $\begin{array}{l}\infty \\
\stackrel{\infty}{\omega} \\
\infty \\
\infty\end{array}$ \\
\hline 吾玉 & $\stackrel{m}{\stackrel{N}{N}}$ & $\overleftarrow{z}$ & $\ddot{\sigma}$ & 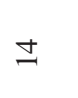 & 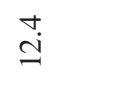 & $\stackrel{\llcorner}{\sim}$ & $\stackrel{\stackrel{n}{\forall}}{\vec{\forall}}$ & $\stackrel{\stackrel{\sim}{d}}{ }$ & $\hat{\text { iे }}$ & 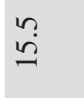 & $\stackrel{\sim}{*}$ & $\stackrel{\llcorner}{\sigma}$ & $\vec{\infty}$ & $\vec{n}$ & $\begin{array}{l}\stackrel{L}{\infty} \\
\infty\end{array}$ & 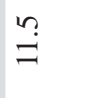 \\
\hline$\stackrel{\mathscr{E}}{E}$ & 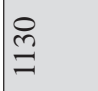 & $\overleftarrow{z}$ & 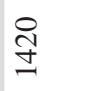 & $\stackrel{0}{\stackrel{0}{n}}$ & $\stackrel{0}{\stackrel{0}{0}}$ & $\underset{-}{ }$ & $\stackrel{\mathscr{I}}{\underset{\sim}{\sim}}$ & 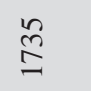 & 周 & $\stackrel{\text { ஸ̂ }}{\underline{-1}}$ & $\frac{10}{8}$ & 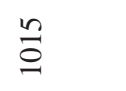 & $\stackrel{\stackrel{L}{N}}{\stackrel{\sim}{\sim}}$ & $\stackrel{\stackrel{N}{\exists}}{\exists}$ & $\stackrel{\text { }}{\underset{\exists}{*}}$ & 농 \\
\hline 龸 & 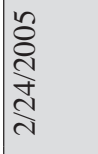 & 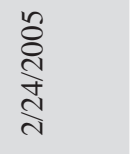 & $\begin{array}{l}\stackrel{0}{O} \\
\stackrel{N}{\mathcal{N}} \\
\stackrel{N}{N}\end{array}$ & $\begin{array}{l}\stackrel{2}{\circ} \\
\stackrel{N}{1} \\
\stackrel{\text { N }}{\sim}\end{array}$ & 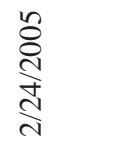 & 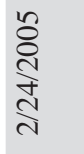 & 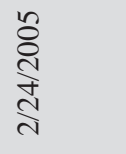 & 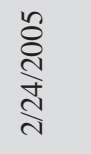 & 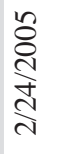 & 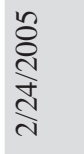 & 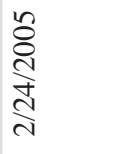 & 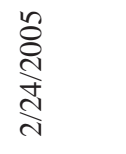 & 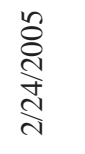 & 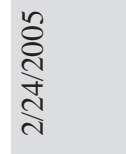 & 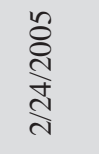 & 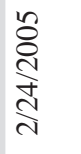 \\
\hline 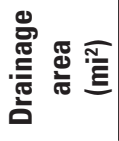 & कें & $\begin{array}{l}\dot{0} \\
\dot{\text { lे }}\end{array}$ & $\overleftrightarrow{z}$ & $\overleftrightarrow{z}$ & $\stackrel{g}{\underset{I}{J}}$ & $\begin{array}{c}m \\
\infty \\
\dot{\sigma}\end{array}$ & $\stackrel{\infty}{\stackrel{0}{R}}$ & ஜ் & 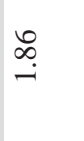 & $\stackrel{8}{\sim}$ & $\begin{array}{l}8 \\
6\end{array}$ & $\begin{array}{l}\text { กิ } \\
\text { ஸุ }\end{array}$ & $\hat{\oplus}$ & $\vec{\infty}$ & $\begin{array}{l}m \\
\text { ma } \\
\stackrel{-}{\circ}\end{array}$ & $\stackrel{9}{\stackrel{9}{ \pm}}$ \\
\hline 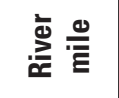 & $\stackrel{\leftrightarrow}{0}$ & น̊ำ & \&̆ & $\begin{array}{l}\stackrel{0}{0} \\
0\end{array}$ & $\stackrel{\sigma}{0}$ & $\begin{array}{l}\text { अे } \\
\text { ம் }\end{array}$ & $\underset{\text { Oे }}{-}$ & 0 & ஸึ? & $\begin{array}{l}\text { ले } \\
\text { ம் }\end{array}$ & $\begin{array}{l}8 \\
\infty \\
\infty\end{array}$ & $\begin{array}{l}\text { mे } \\
\text { ले }\end{array}$ & $\stackrel{N}{0}$ & $\begin{array}{l}\stackrel{\imath}{i} \\
\stackrel{i}{ }\end{array}$ & ర़ & $\stackrel{8}{0}$ \\
\hline 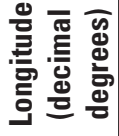 & $\begin{array}{l}\stackrel{+}{7} \\
\overrightarrow{7} \\
\stackrel{\infty}{\infty}\end{array}$ & $\overleftrightarrow{Z}$ & $\begin{array}{l}\stackrel{9}{\overrightarrow{7}} \\
\stackrel{+}{\infty} \\
\infty\end{array}$ & 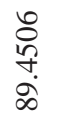 & 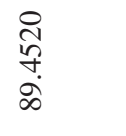 & $\begin{array}{l}8 \\
0 \\
4 \\
0 \\
\infty\end{array}$ & \begin{tabular}{l}
$\stackrel{0}{1}$ \\
\multirow{2}{+}{} \\
$\infty$ \\
$\infty$
\end{tabular} & \begin{tabular}{l}
$\stackrel{\text { 尔 }}{f}$ \\
\multirow{+}{\infty}{} \\
$\infty$
\end{tabular} & \begin{tabular}{l}
$\hat{\sigma}$ \\
\multirow{2}{+}{} \\
$\stackrel{0}{\infty}$
\end{tabular} & 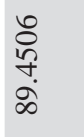 & $\begin{array}{l}\text { शे } \\
\text { ले } \\
\text { ळ. }\end{array}$ & 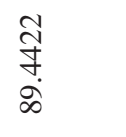 & $\begin{array}{l}\text { 9) } \\
0 \\
+ \\
\infty \\
\infty\end{array}$ & 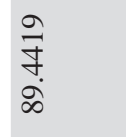 & $\begin{array}{l}\infty \\
\stackrel{0}{0} \\
\stackrel{+}{+} \\
\infty \\
\infty\end{array}$ & $\begin{array}{l}\infty \\
\stackrel{1}{0} \\
\infty \\
\infty \\
\infty\end{array}$ \\
\hline 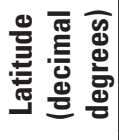 & $\begin{array}{l}\tilde{D} \\
\stackrel{\alpha}{o} \\
\ddot{y} \\
\dot{\gamma}\end{array}$ & $\overleftrightarrow{z}$ & 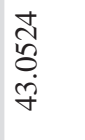 & 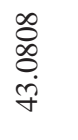 & 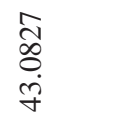 & $\begin{array}{l}0 \\
\ddot{0} \\
0 \\
\ddot{y}\end{array}$ & 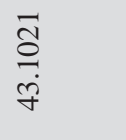 & 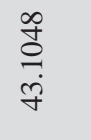 & 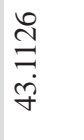 & $\begin{array}{l}\tilde{I} \\
\overrightarrow{\tilde{F}} \\
\dot{F}\end{array}$ & $\begin{array}{l}\stackrel{\mathcal{N}}{\exists} \\
\underset{\sim}{\tilde{y}}\end{array}$ & 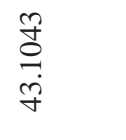 & 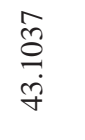 & $\begin{array}{l}\text { 告 } \\
\text { Oे. } \\
\text { r্ }\end{array}$ & 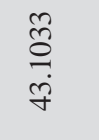 & $\begin{array}{l}\vec{m} \\
\stackrel{0}{0} \\
\ddot{y}\end{array}$ \\
\hline 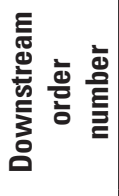 & 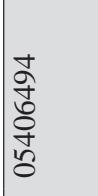 & $\begin{array}{l}8 \\
0 \\
0 \\
0 \\
\square \\
0\end{array}$ & 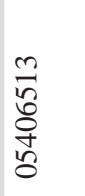 & 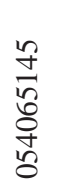 & 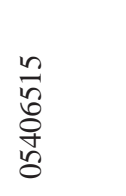 & $\begin{array}{l}\infty \\
0 \\
0 \\
0 \\
0 \\
\bigsqcup \\
0\end{array}$ & 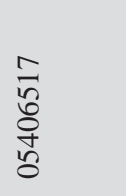 & 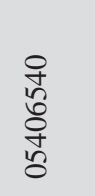 & 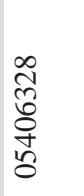 & 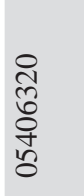 & 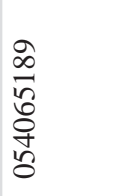 & 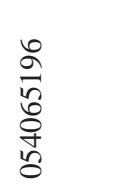 & 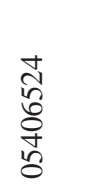 & 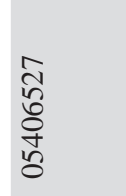 & \begin{tabular}{l} 
तิ \\
ర్ \\
0 \\
\multirow{0}{0}{}
\end{tabular} & 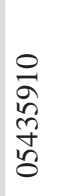 \\
\hline 总 & $\begin{array}{l}m \\
\vdots \\
u \\
\text { y1 } \\
m\end{array}$ & $\overleftarrow{z}$ & $\begin{array}{l}0 \\
\vdots \\
\substack{11 \\
0}\end{array}$ & 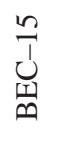 & $\begin{array}{l}\infty \\
\vec{u} \\
\text { 章 } \\
0\end{array}$ & $\begin{array}{l}\vec{J} \\
u \\
1 \\
0\end{array}$ & $\underset{\substack{0 \\
\text { I1 } \\
0}}{0}$ & 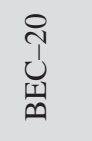 & 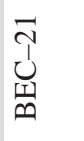 & 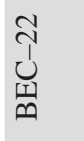 & $\begin{array}{l}\stackrel{N}{N} \\
\bigcup_{\substack{1 \\
\infty}}\end{array}$ & 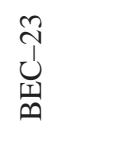 & 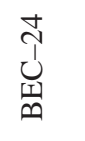 & $\begin{array}{c}\text { N } \\
\text { ù } \\
\text { II }\end{array}$ & 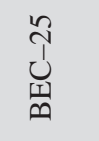 & 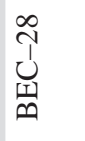 \\
\hline 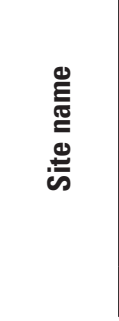 & 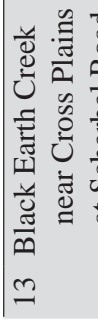 & 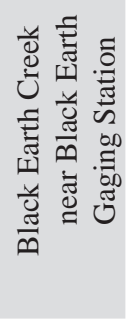 & 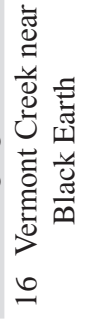 & 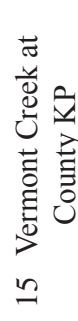 & 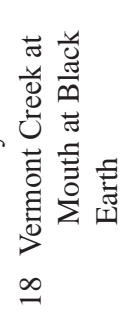 & 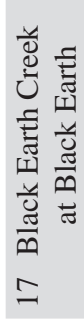 & 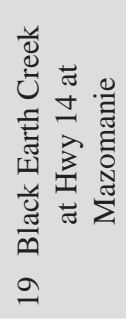 & 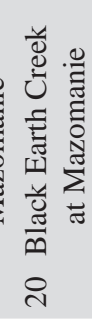 & 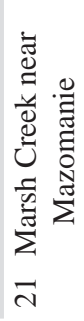 & 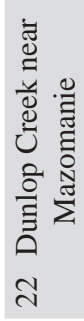 & 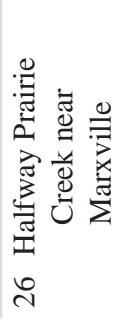 & 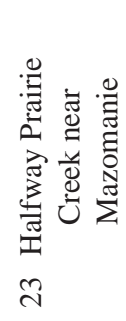 & 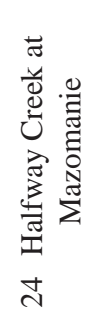 & 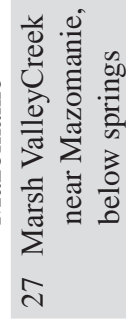 & 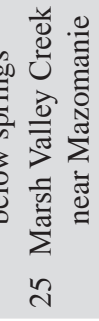 & 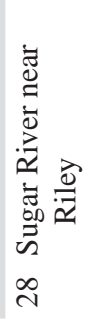 \\
\hline
\end{tabular}




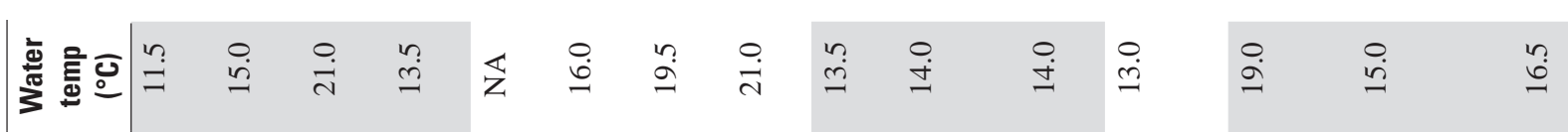

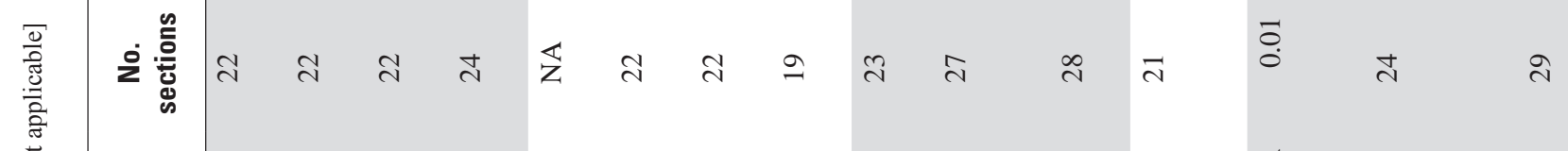

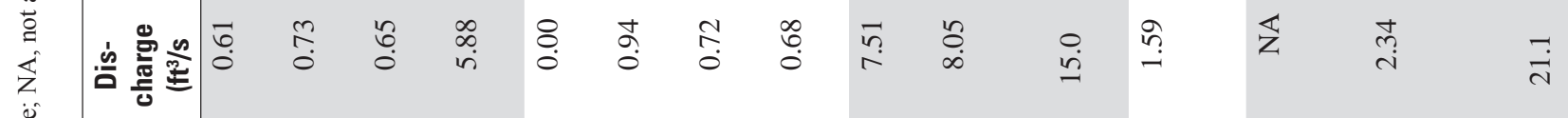

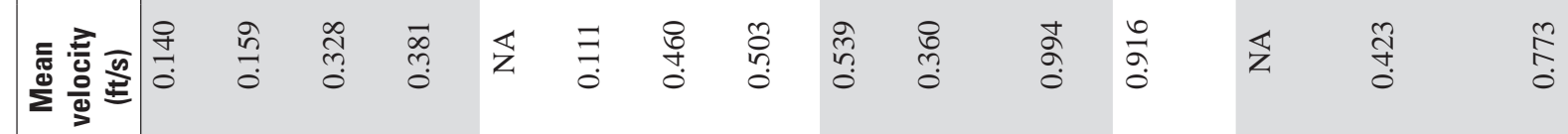

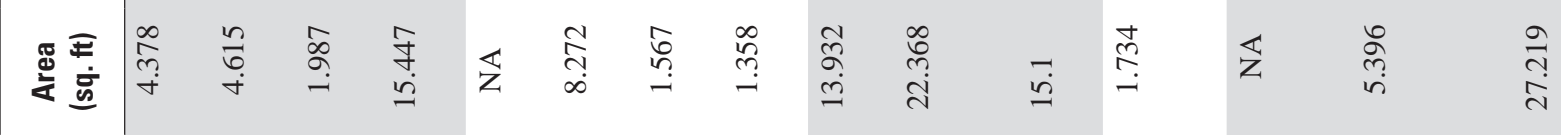

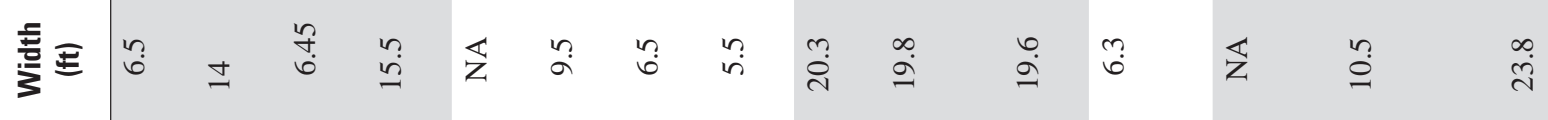

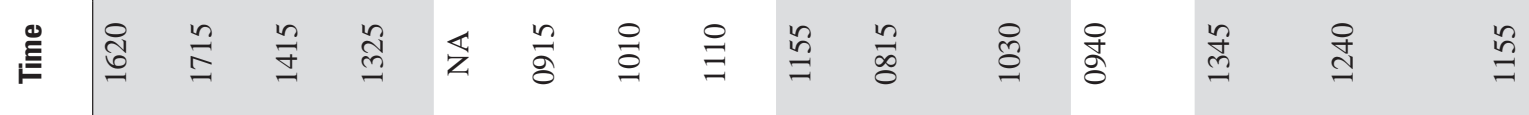

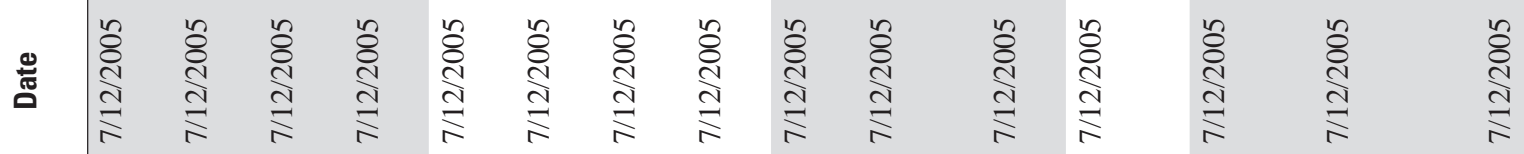

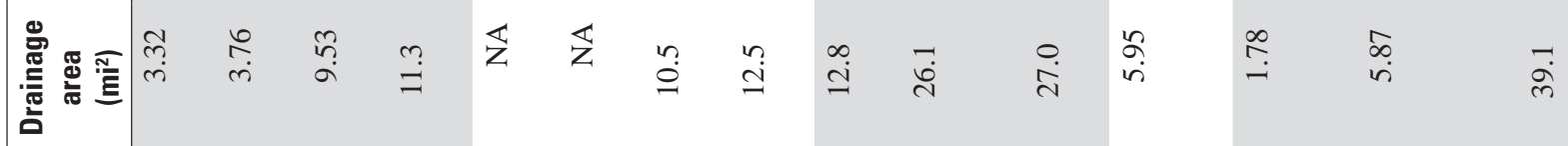

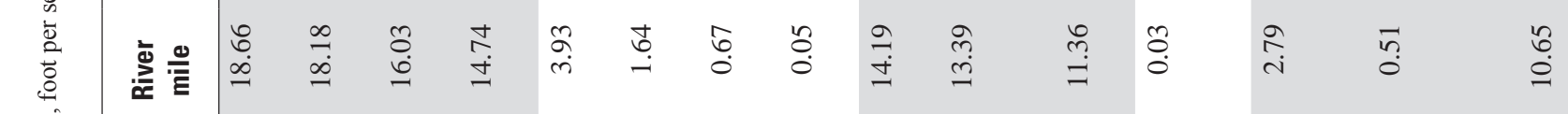

$\stackrel{\text { m }}{\rightleftarrows}$

蒫

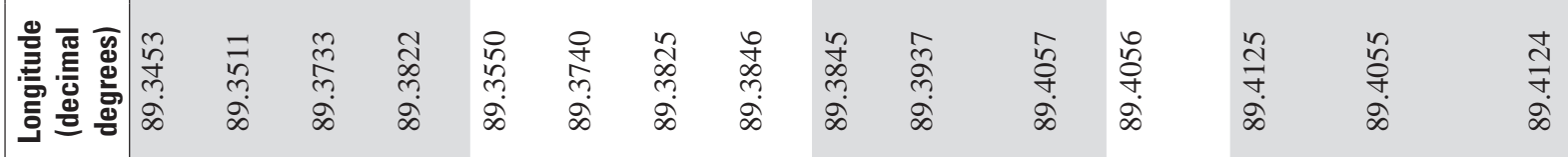

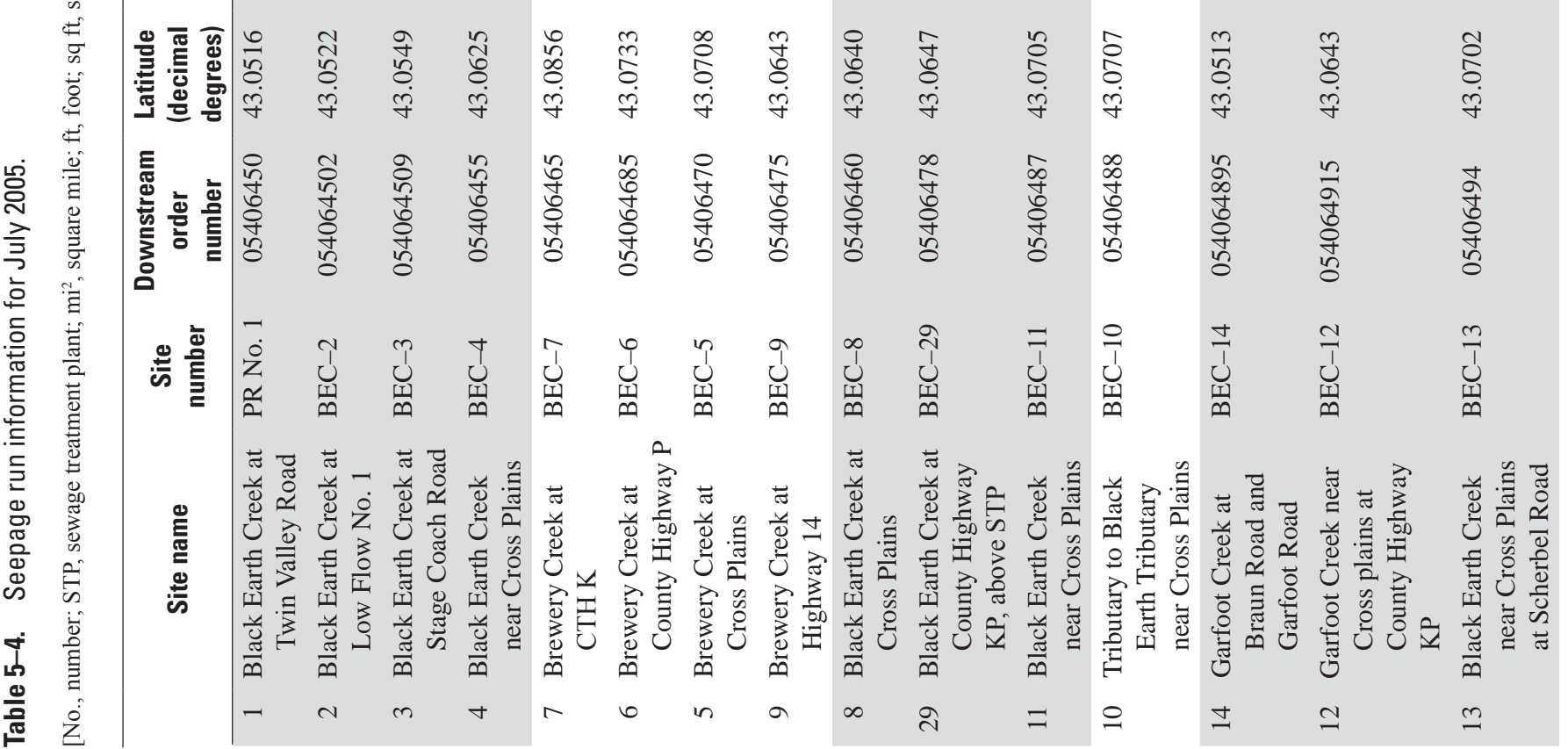




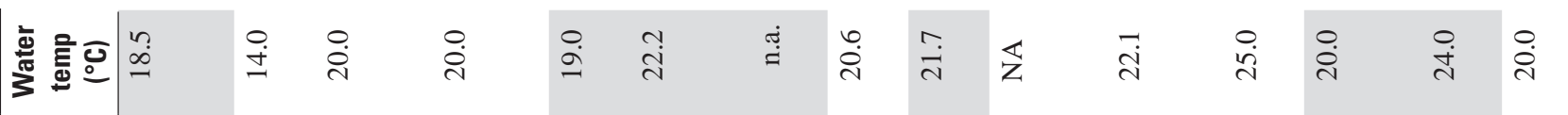
离

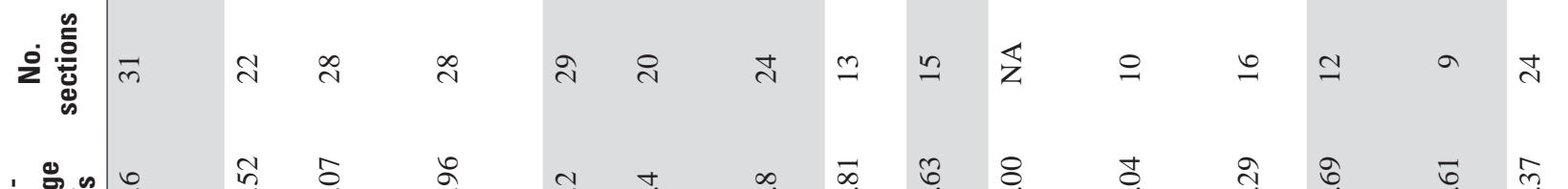

藮 ๘ 递蹗

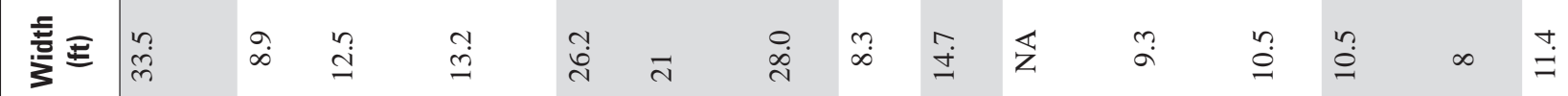

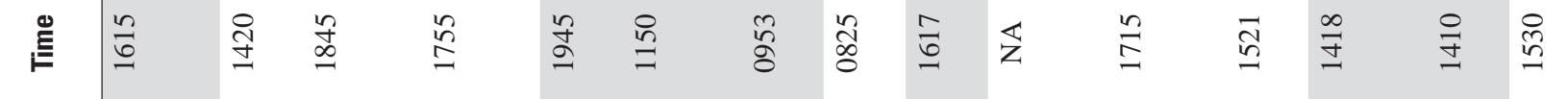

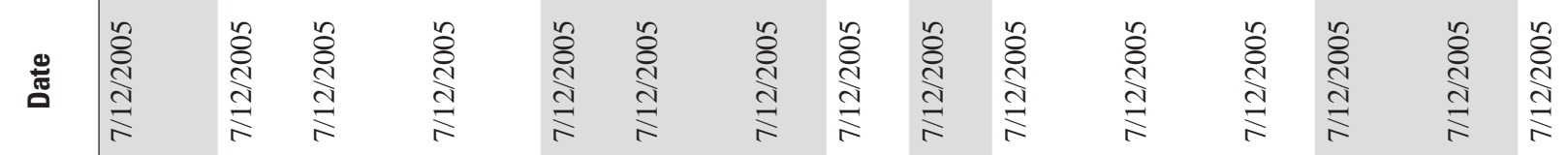

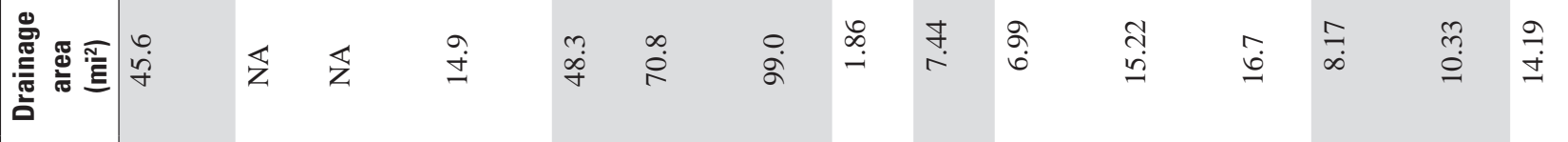

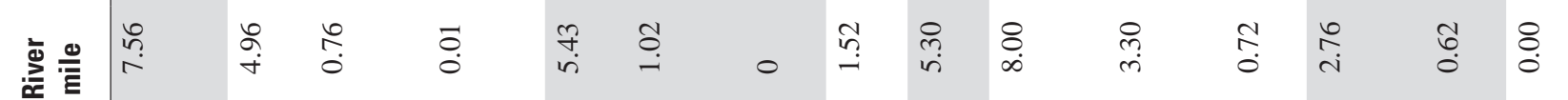

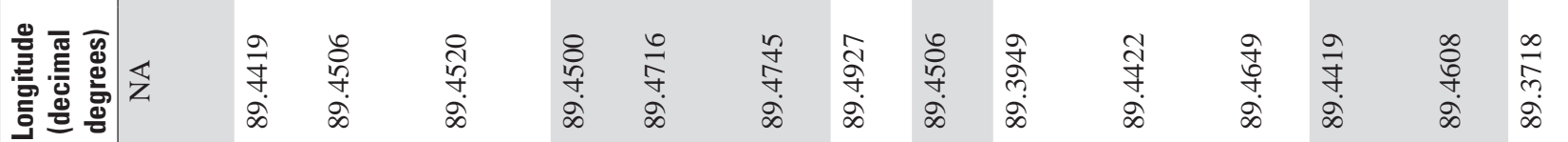

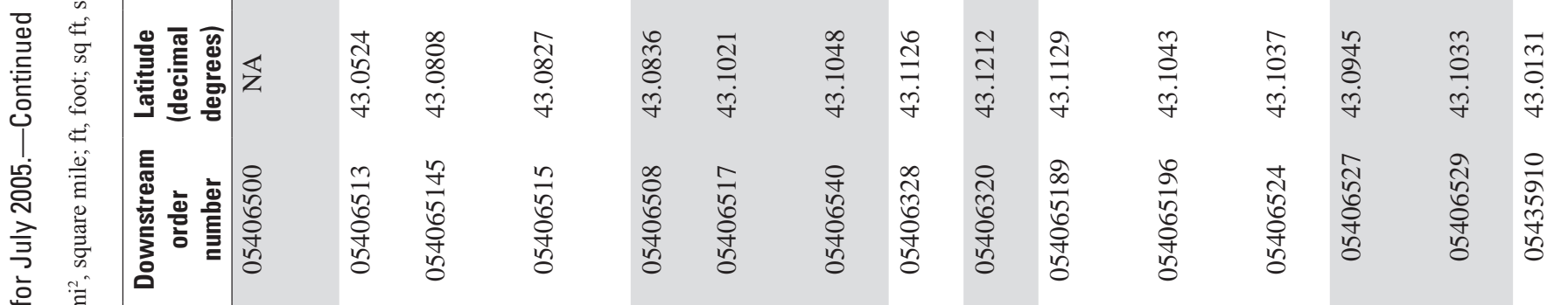

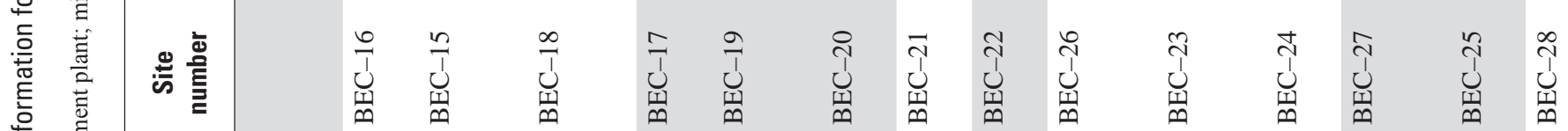




\section{Groundwater Elevation}

In addition to existing data used for model calibration, groundwater elevation time-series data were collected at five locations within the Black Earth Creek watershed during 2005-7 (table 5-5). The water levels were collected using unvented pressure transducers with a 1-hour recording interval and were compensated for atmospheric pressure fluctuations using a barometric pressure transducer. These data are reported in Waschbusch and others (2005) and can also be accessed online at http://maps.waterdata.usgs.gov/mapper/index.html. Recorded water levels were compared to hand measurements made approximately monthly; the differences between the observed and recorded values were used to adjust the recorded time series.

\section{References Cited}

Waschbusch, R.J., Olson, D.L., and Marsh, S.B., 2005, Water resources data-Wisconsin, water year 2005: U.S. Geological Survey Water-Data Report WI-05-1, 982 p.

Table 5-5. Description of sites with continuous-record groundwater levels in the Black Earth Creek watershed.

\begin{tabular}{|c|c|c|c|c|c|}
\hline Station number & $\begin{array}{c}\text { Station well identifier } \\
\text { and name }\end{array}$ & Type & $\begin{array}{l}\text { Well depth } \\
\text { (feet) }\end{array}$ & $\begin{array}{c}\text { Latitude } \\
\text { (degrees, minutes, } \\
\text { seconds) }\end{array}$ & $\begin{array}{c}\text { Longitude } \\
\text { (degrees, minutes, } \\
\text { seconds) }\end{array}$ \\
\hline 430511089410301 & DN1363 FF-12 & Potentiometric surface & 228.8 & $43^{\circ} 05^{\prime} 11^{\prime \prime}$ & $-89^{\circ} 41^{\prime} 03^{\prime \prime}$ \\
\hline 430511089410302 & DN1364 FF-13 & Potentiometric surface & 175.3 & $43^{\circ} 05^{\prime} 11^{\prime \prime}$ & $-89^{\circ} 41^{\prime} 03^{\prime \prime}$ \\
\hline 430544089342201 & DN1239 P-36D & Potentiometric surface & 239.9 & $43^{\circ} 05^{\prime} 44^{\prime \prime}$ & $-89^{\circ} 34^{\prime} 22^{\prime \prime}$ \\
\hline 430516089345101 & DN1484 P-38 & Water table & 23.7 & $43^{\circ} 05^{\prime} 16^{\prime \prime}$ & $-89^{\circ} 34^{\prime} 51^{\prime \prime}$ \\
\hline 430532089351401 & DN1404 Mt. Simon deep & Potentiometric surface & 448 & $43^{\circ} 05^{\prime} 32^{\prime \prime}$ & $-89^{\circ} 35^{\prime} 15^{\prime \prime}$ \\
\hline
\end{tabular}




\section{Appendix 6. Calibration}

\section{Precipitation-Runoff Modeling System (PRMS)- Only Calibration Results}

The results for step 1 of the Black Earth Creek model calibration of solar radiation and potential evapotranspiration (ET) are given in figures 6-1 and 6-2, respectively, where both are well simulated. The results for step 2 of the calibration, snowpack, are given in figure $6-1 \mathrm{C}$. The model does a reasonable job of reproducing the onset of the snowpack in the fall, the end of the snowpack in spring, and the general pattern of accumulation and ablation. The agreement is not exact due to localized variations in snowpack depth. We selected a single hydrologic response unit (HRU) (number 289) to represent the data collected at the Truax Field meteorological station, and in addition to the distance from the station and the Black Earth Creek watershed, the local conditions are likely different between HRU 289 and the Truax Field station; however, on the basis of the results shown in figure 6-1C, the model is reasonably representing the overall variation in the snowpack.

The results for step 3 of the calibration-surface-water runoff and soil infiltration - are shown in figures 6-2 through 6-4. Because the Precipitation-Runoff Modeling System (PRMS) model was built specifically for a coupled GSFLOW model, we adjusted the parameters until the results represented a reasonable starting point for the GSFLOW calibration. The adjustment was done partly because most of the parameters would have to be revisited during the GSFLOW model calibration and partly because the PRMS model uses a different set of processes than GSFLOW to represent groundwater flow. The results for annual streamflow in Black Earth Creek and its tributary streams (figs. 6-2 through 6-7) show a reasonable representation of the annual water budget. The monthly mean streamflow plots reproduce the general seasonal patterns at the sites but are less robust in their ability to track the month-tomonth variations in flow. The mean monthly plots represent the mean calculated for each month during the calibration period (for example, observation 1 is the mean of all January monthly flows during the calibration period, observation 12 is the mean of all December monthly flows during the calibration period). The results for Black Earth Creek at Mazomanie (fig. 6-7), which is the outlet of the watershed, indicate that the overall annual budget of the watershed is being reproduced and that much of the seasonal variation of flow out of the watershed is being reproduced with sufficient accuracy to form a starting point for fully coupled model calibration. Because uncoupled results are only interim steps to the final fully coupled model calibration, detailed discussion on calibration of the uncoupled models is not provided. Improvement in calibration obtained from the fully coupled model is shown by comparing the initial PRMS-only calibration best-fit results in figures 6-2 through 6-7 to their equivalent plots from the fully couple model calibration in figures 6-14 through 6-19.

\section{Uncoupled MODFLOW-only Calibration Results}

After the soft-knowledge and simulated best-fit tradeoff was selected, the resulting parameter sets are reasonable given other values reported for the watershed (table 2 in main report). The glacio-fluvial sand and gravel sediments in the Black Earth Creek main stem had the highest hydraulic conductivities in the watershed, reflecting coarse sediments deposited when the glacial ice front was at its farthest extent (Clayton and Attig, 1997). Horizontal to vertical hydraulic conductivity $\left(\mathrm{K}_{\mathrm{h}}\right.$ and $\mathrm{K}_{\mathrm{v}}$, respectively) anisotropy ratio (table 2 in main report) were reasonable, with $\mathrm{K}_{\mathrm{h}}$ greater than $\mathrm{K}_{\mathrm{v}}$ in most cases. The MODFLOW-only model was able to adequately simulate the head observations; final calibration statistics are listed in table 6-1. Simulated heads tracked observed heads over the range of head values (fig. 6-8), for the 2005 contemporaneous measurements (fig. 6-9), and for head difference targets (fig. 6-10). Average base flows for the tributary streams were generally well simulated for the entire watershed (fig. 6-11), Black Earth Creek headwaters (fig. 6-12), and Black Earth Creek tributaries (fig. 6-13). Overall, the model fit to observed data is better than for previous modeling efforts in the watershed for a larger range of observation types, despite the higher number of targets and additional types of calibration constraints used.

\section{Fully Coupled GSFLOW Calibration Results}

Potential and actual evaporation, timing, and magnitude of snowpack accumulation and snowmelt were simulated by using the uncoupled PRMS model calibration (fig. 6-1); the associated parameters for these processes were not adjusted by subsequent calibration. Observed flow characteristics for the Black Earth Creek watershed were well represented (fig. 6-14) at the streamgaging station with the longest record, Black Earth Creek at Black Earth (station 05406500), which reflected the weight at this location during calibration. The other streamgages with multiple years of record during the calibration period were acceptably simulated (figs. 6-15 and fig. 6-16). Streamgages with 1-year records collected as part of the study were also acceptably simulated (figs. 6-17 through 6-19). Of these, the most downstream streamgage, Black Earth Creek at Mazomanie (station 05406540), was relatively better simulated (fig. 6-19) than other streamgages with 1 year of record. Hunt and others (2005) point out the statistical influence typical of the most downstream gage, so it too was given elevated weighting during calibration. 


\section{A. Basinwide monthly solar radiation}

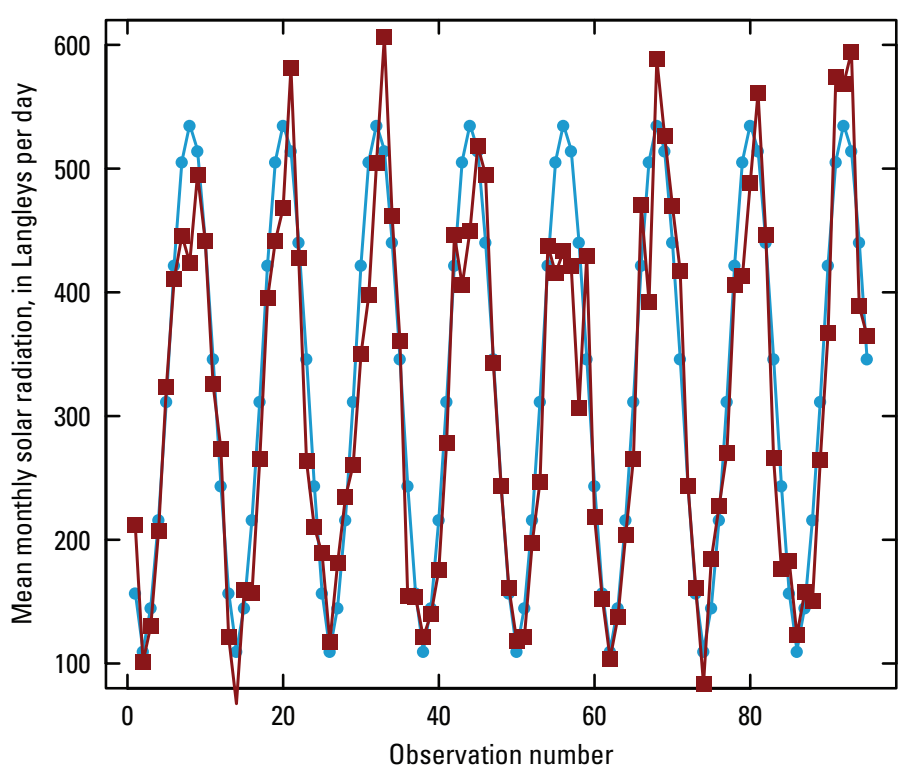

C. Snowpack depth at Truax Field

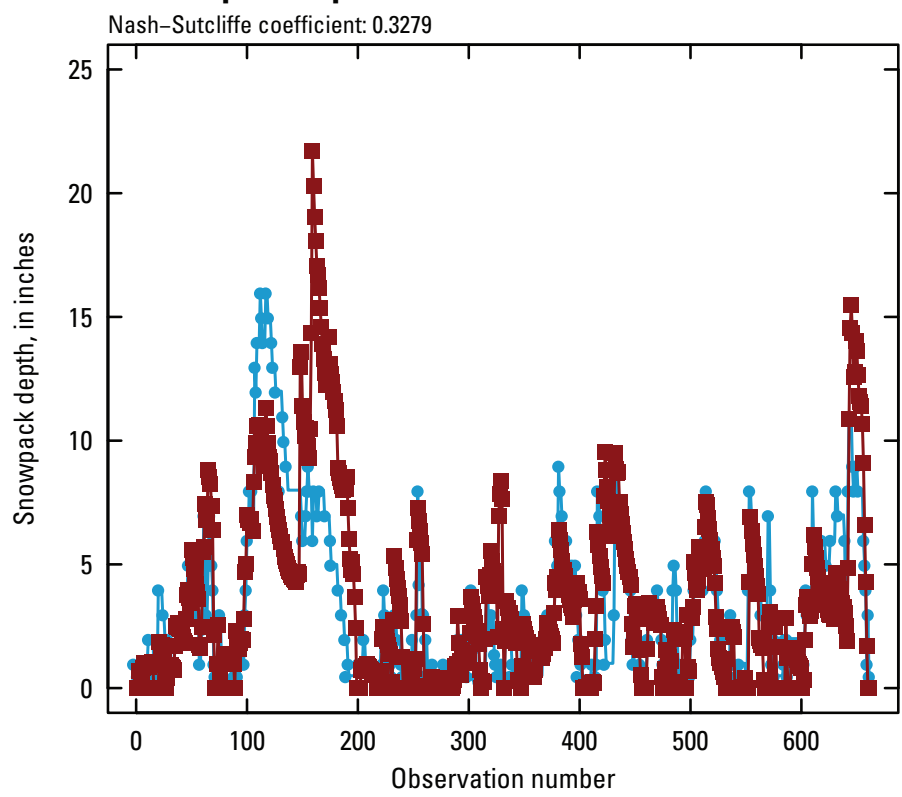

B. Basinwide monthly potential evapotransporation (PET) Nash-Sutcliffe coefficient: 0.8396

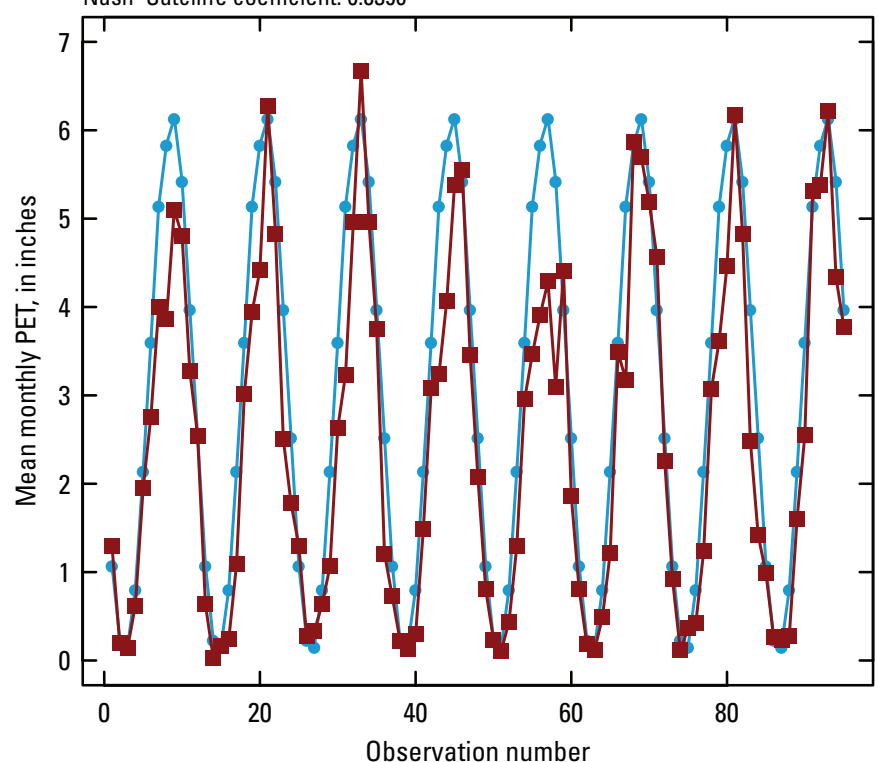

Figure 6-1. A, Solar radiation and $B$, potential evapotranspiration results for step 1 calibration, and $C$, snowpack results for step 2 calibration. Blue lines and symbols are observed data; red lines and symbols are the model-simulated equivalent quantity. For figure readability and to facilitate comparison across figures, the $x$-axis shows the observation number as a temporally sequential order of the observation. The $\mathrm{x}$-axis spans the 2000-7 calibration period and does not display gaps in the observed time series. 
A. Daily streamflow

Nash-Sutcliffe coefficient: 0.65

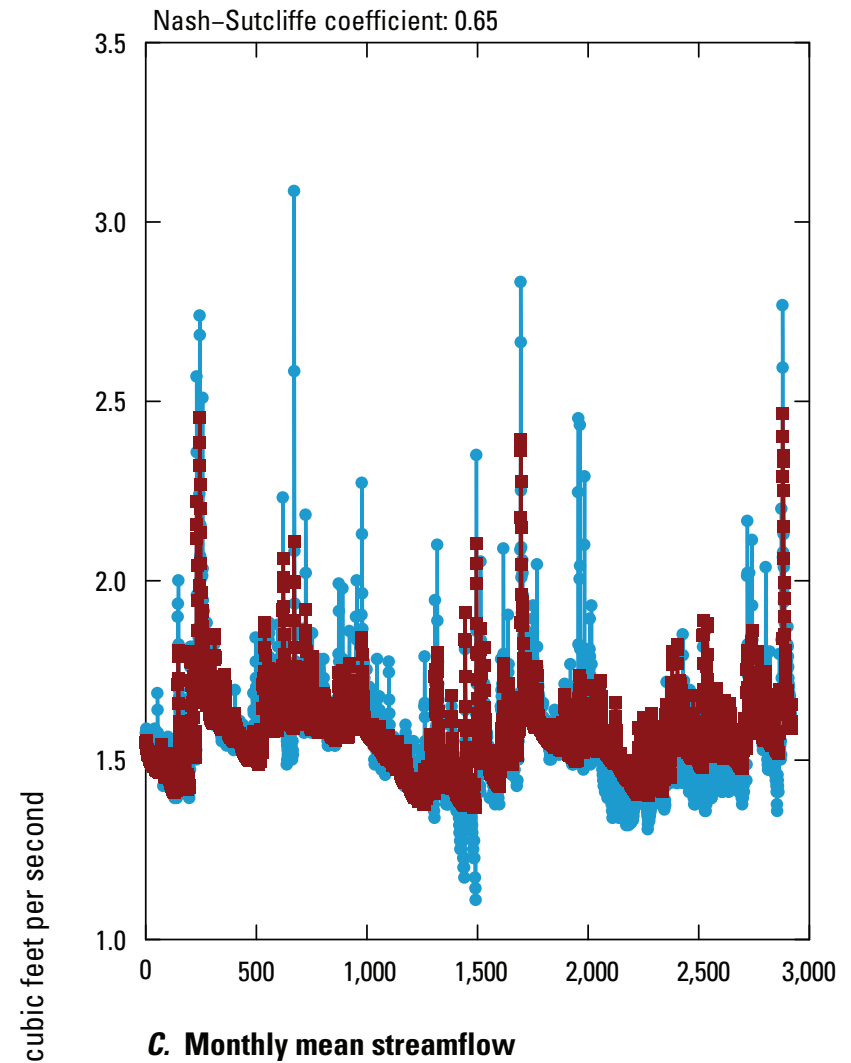

Nash-Sutcliffe coefficient: 0.71

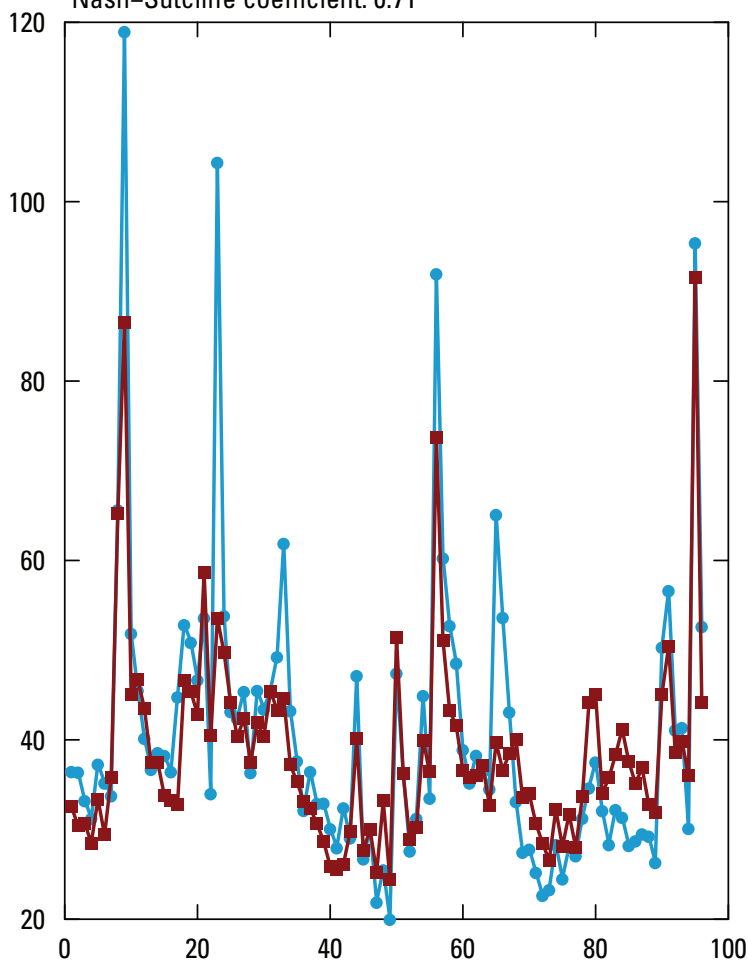

\section{B. Annual mean streamflow}
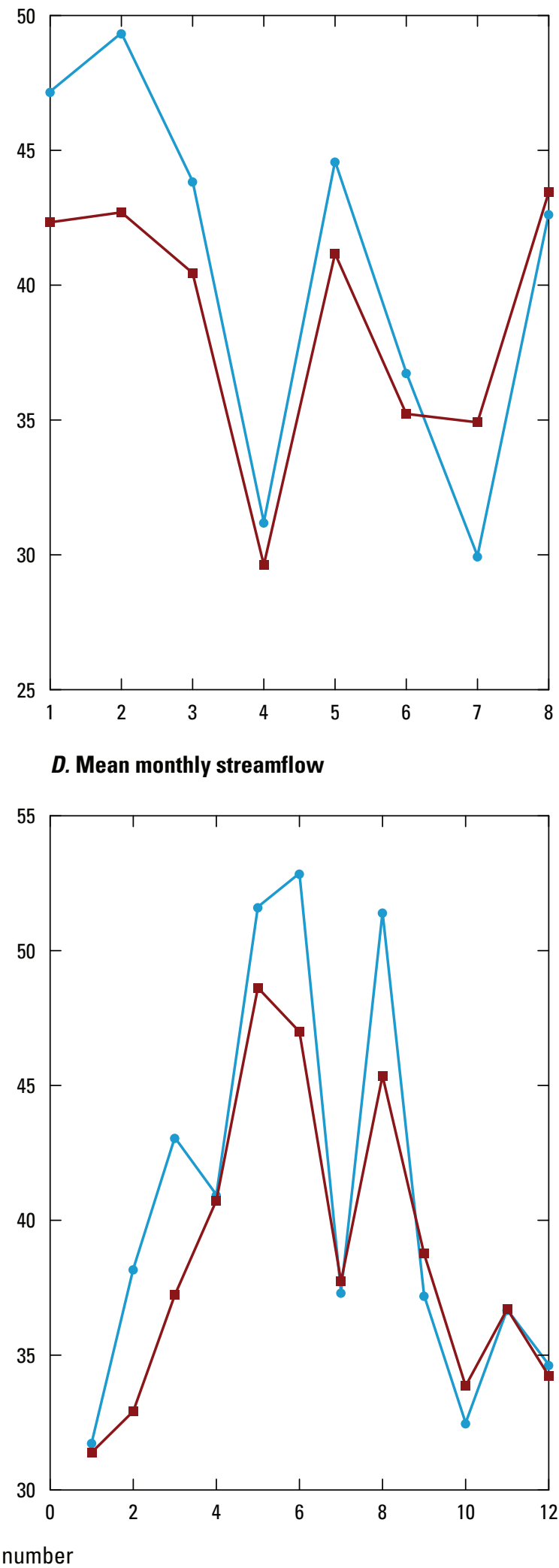

Figure 6-2. Initial uncoupled calibration results for long-term streamgage 05406500, Black Earth Creek at Black Earth, for $A$, the $\log$ of daily streamflow; $B$, mean annual streamflow; $C$, monthly mean streamflow; and $D$, mean monthly streamflow calculated for 8 years of record. Blue lines represent observed data; red lines and symbols are the PRMS-only model-simulated equivalent quantity. These results were interim results for calibration as these observations were included in the final fully coupled model calibration. 
A. Daily streamflow

Nash-Sutcliffe coefficient: 0.097

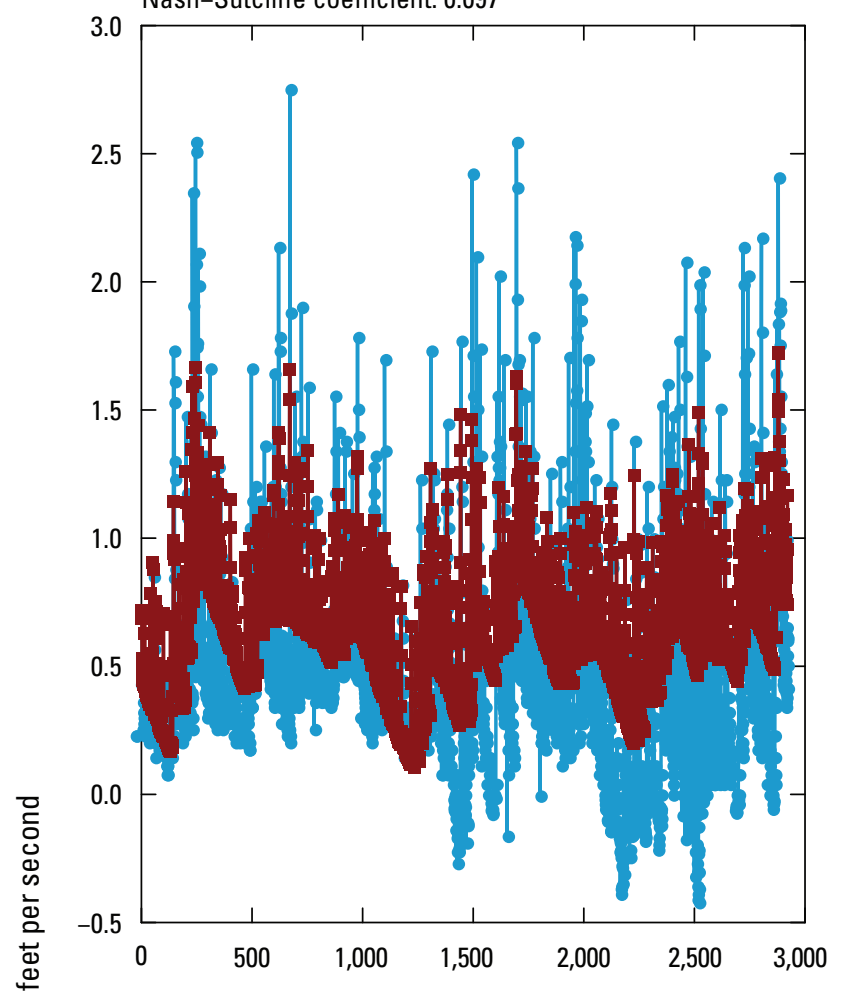

C. Monthly mean streamflow

Nash-Sutcliffe coefficient: 0.4

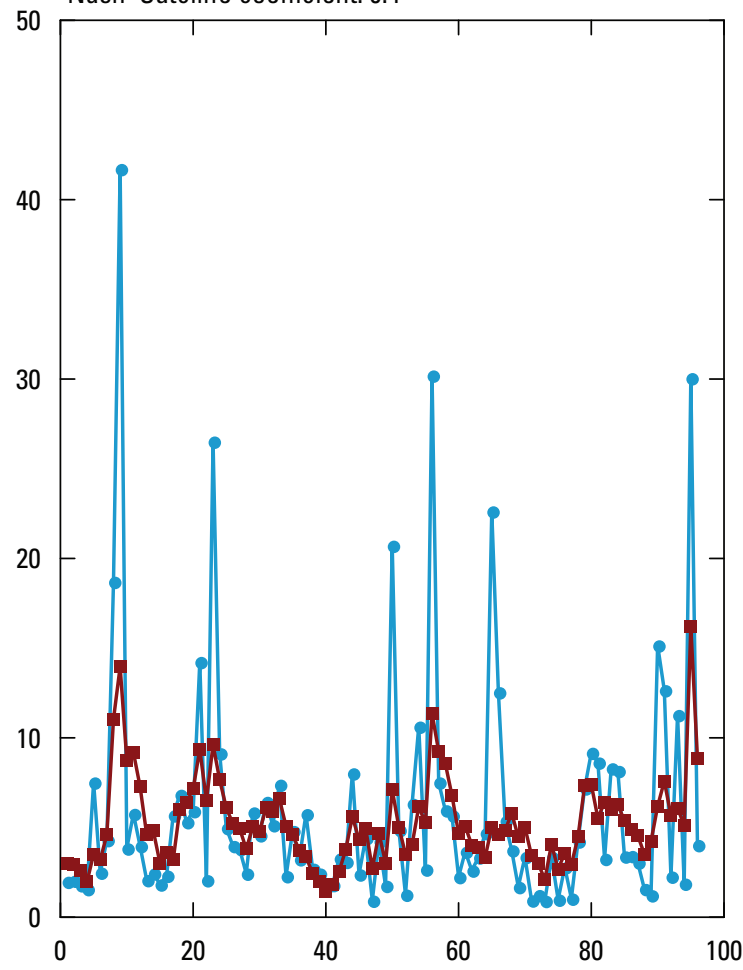

\section{B. Annual mean streamflow}

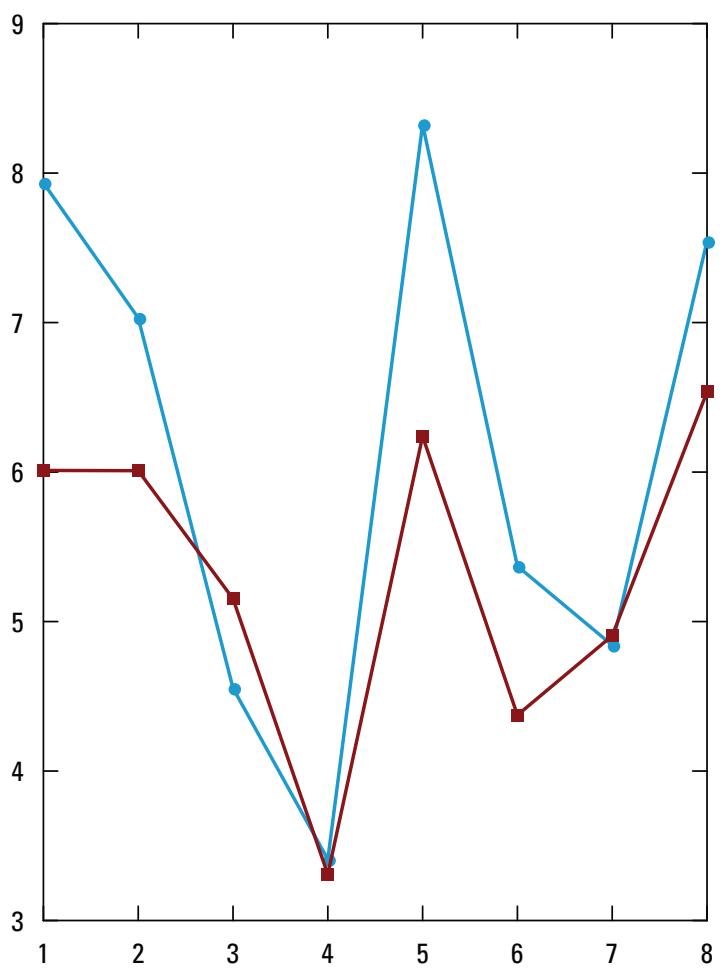

D. Mean monthly streamflow

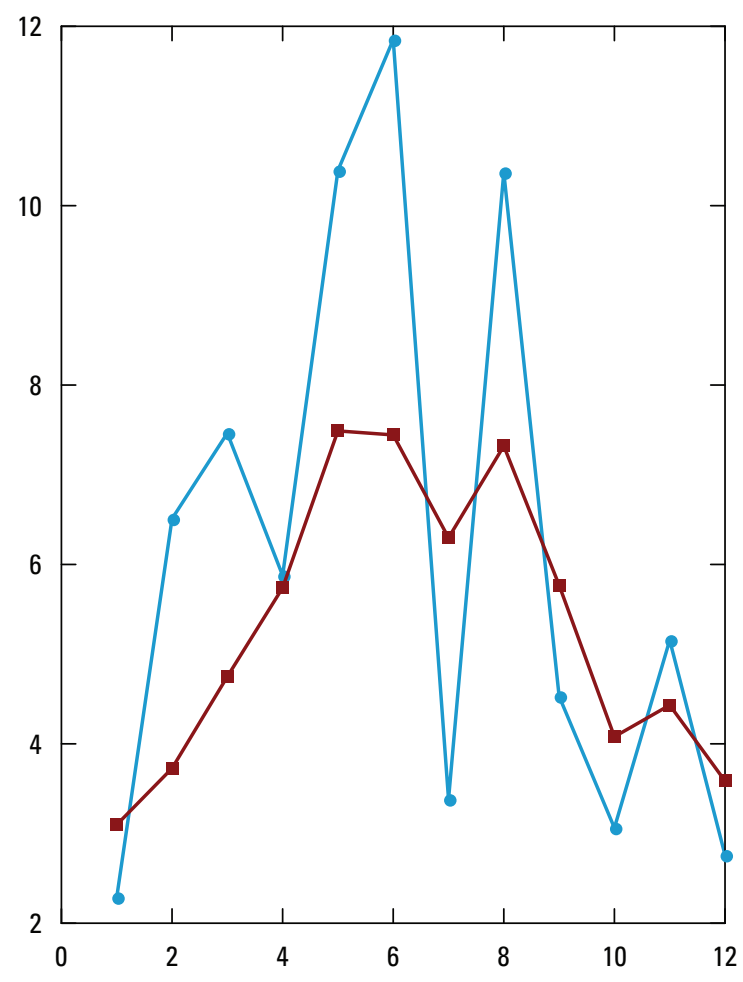

Observation number

Figure 6-3. Initial uncoupled calibration results for long-term streamgage 05427948, Pheasant Branch at Middleton, for $A$, the $\log$ of daily streamflow; $B$, mean annual streamflow; $C$, monthly mean streamflow; and $D$, mean monthly streamflow calculated for 8 years of record. Blue lines represent observed data; red lines and symbols are the PRMS-only model-simulated equivalent quantity. These results were interim results for calibration as these observations were included in the final fully coupled model calibration. 
A. Daily streamflow

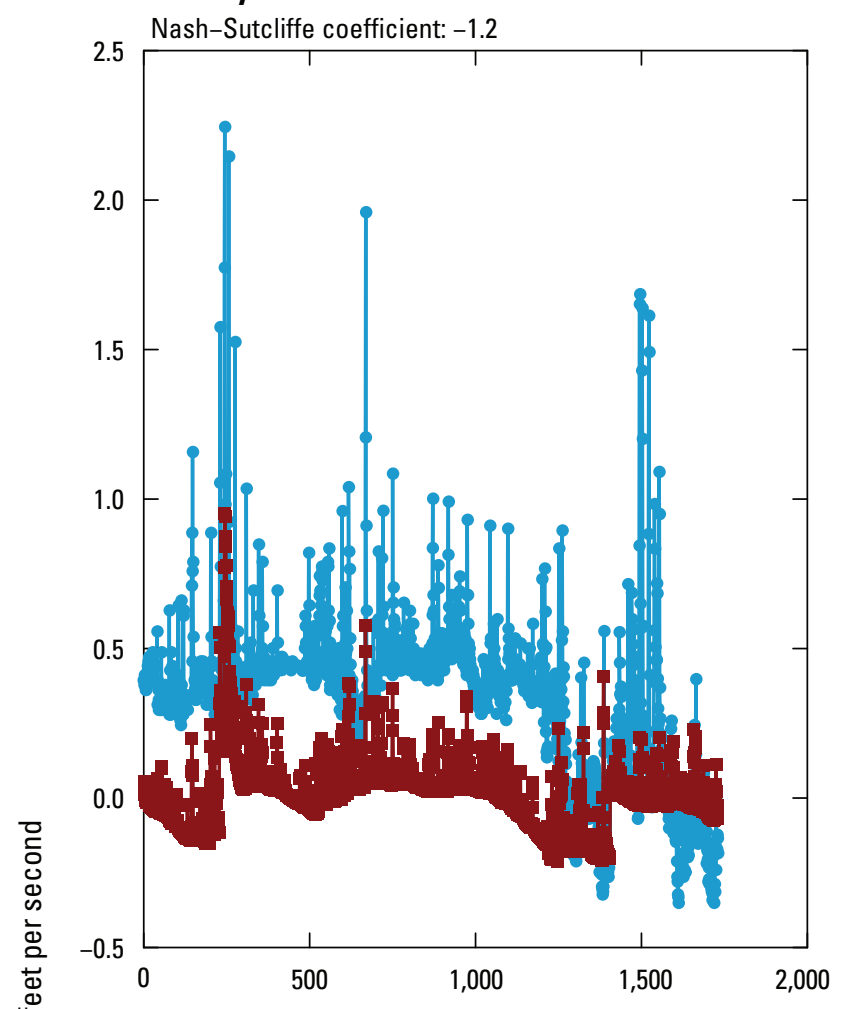

C. Monthly mean streamflow

Nash-Sutcliffe coefficient: -0.5

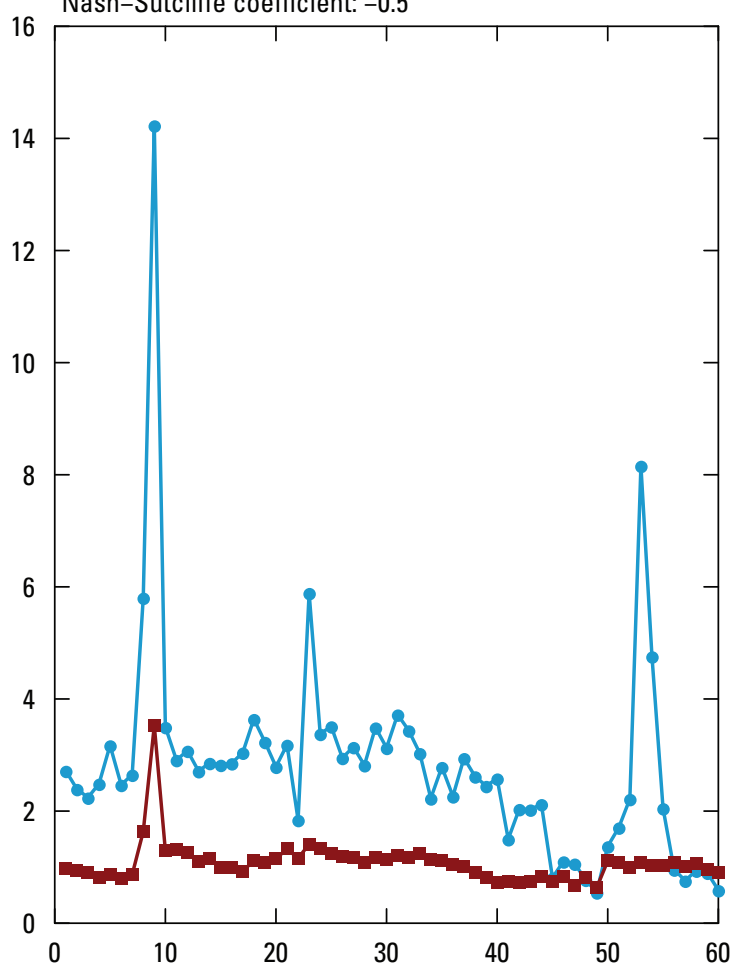

B. Annual mean streamflow

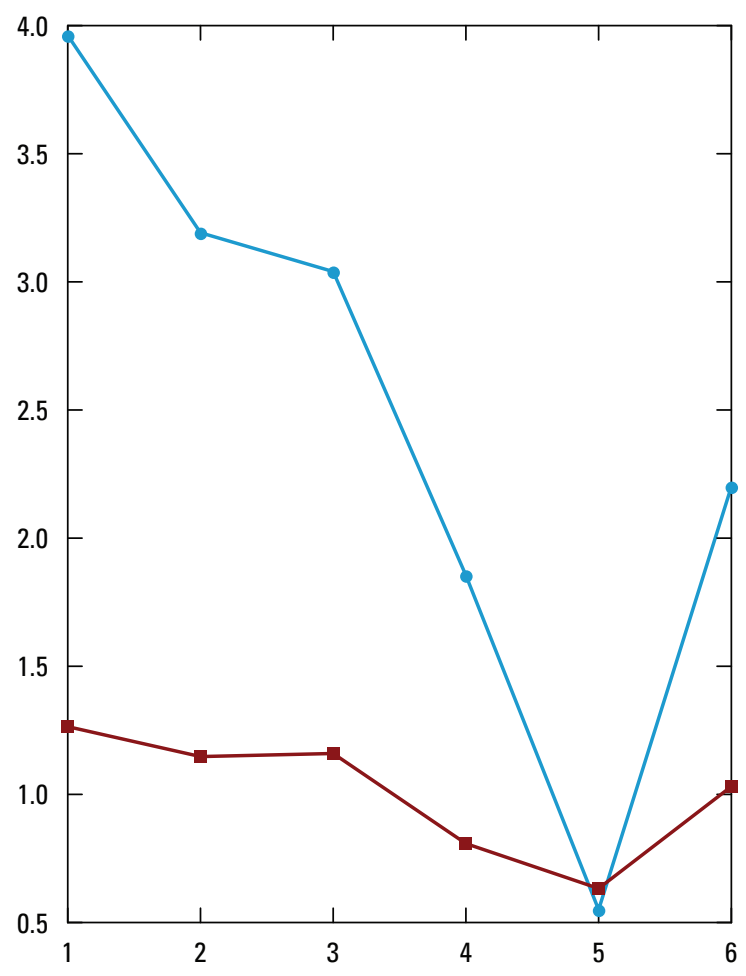

D. Mean monthly streamflow

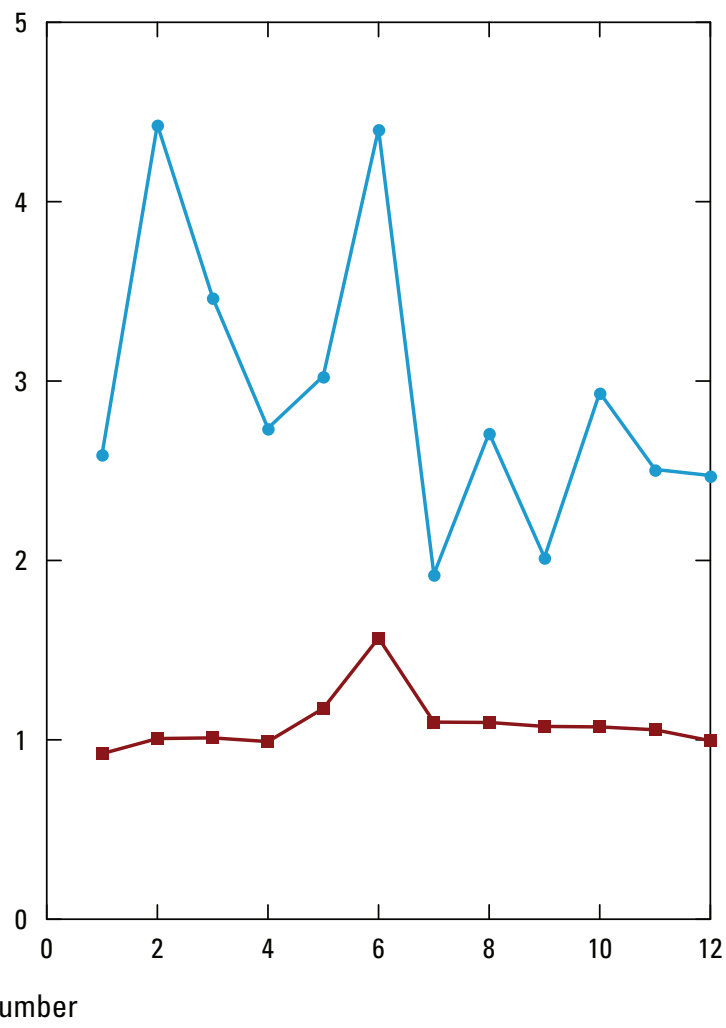

Figure 6-4. Initial uncoupled calibration results for long-term streamgage 05427948, Brewery Creek at Cross Plains, for $A$, the $\log$ of daily streamflow; $B$, mean annual streamflow; $C$, monthly mean streamflow; and $D$, mean monthly streamflow calculated for 6 years of record. Blue lines represent observed data; red lines and symbols are the PRMS-only model-simulated equivalent quantity. These results were interim results for calibration as these observations were included in the final fully coupled model calibration. 
A. Daily streamflow

Nash-Sutcliffe coefficient: 0.47

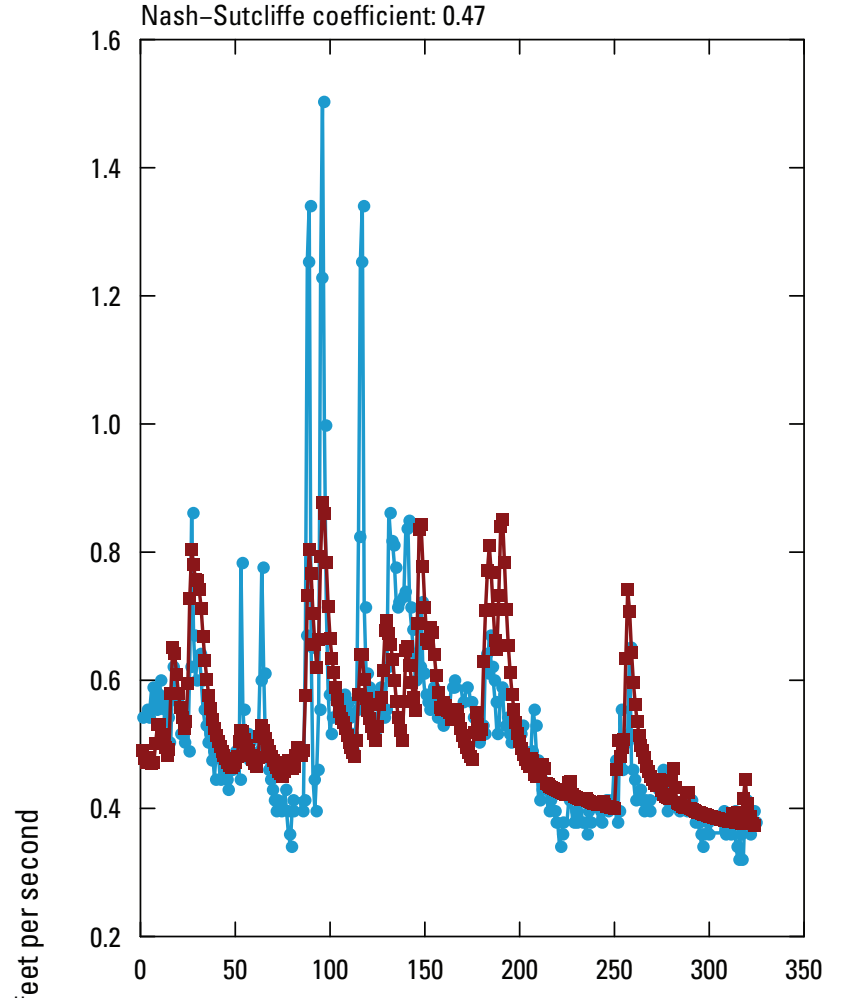

C. Monthly mean streamflow

Nash-Sutcliffe coefficient: 0.51

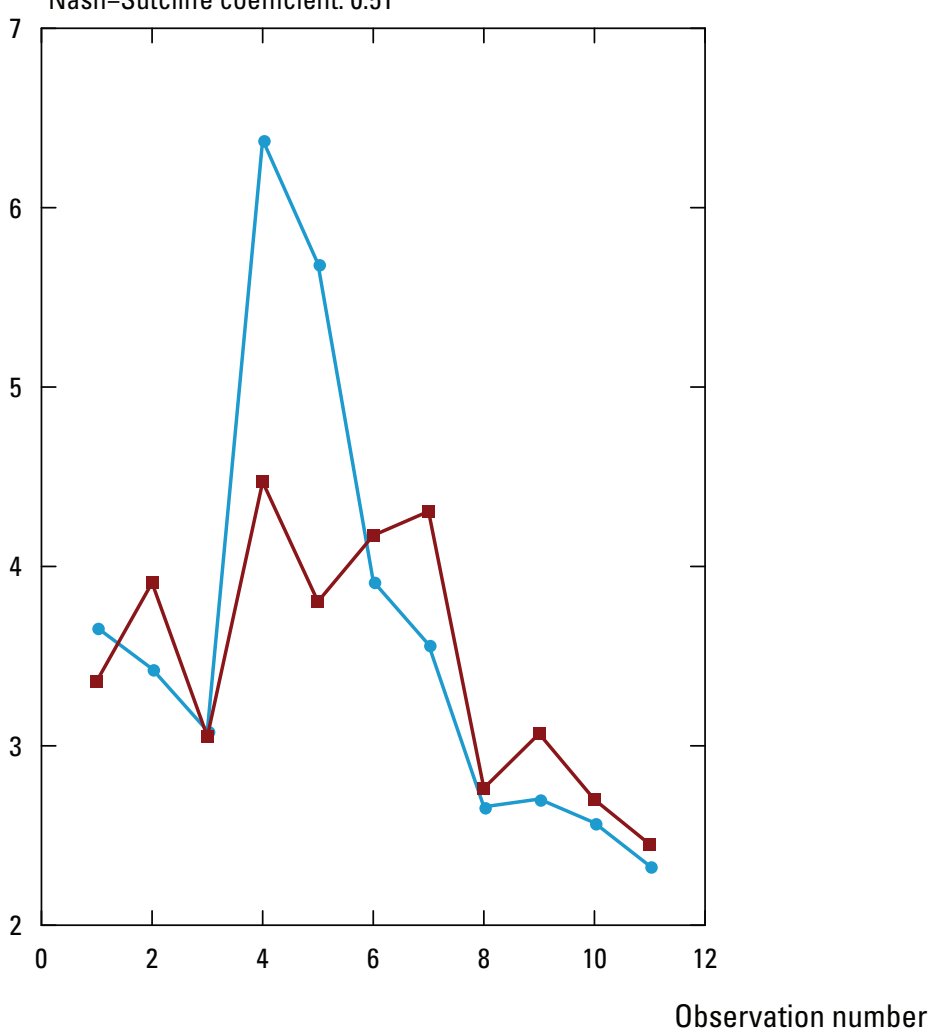

\section{B. Annual mean streamflow}

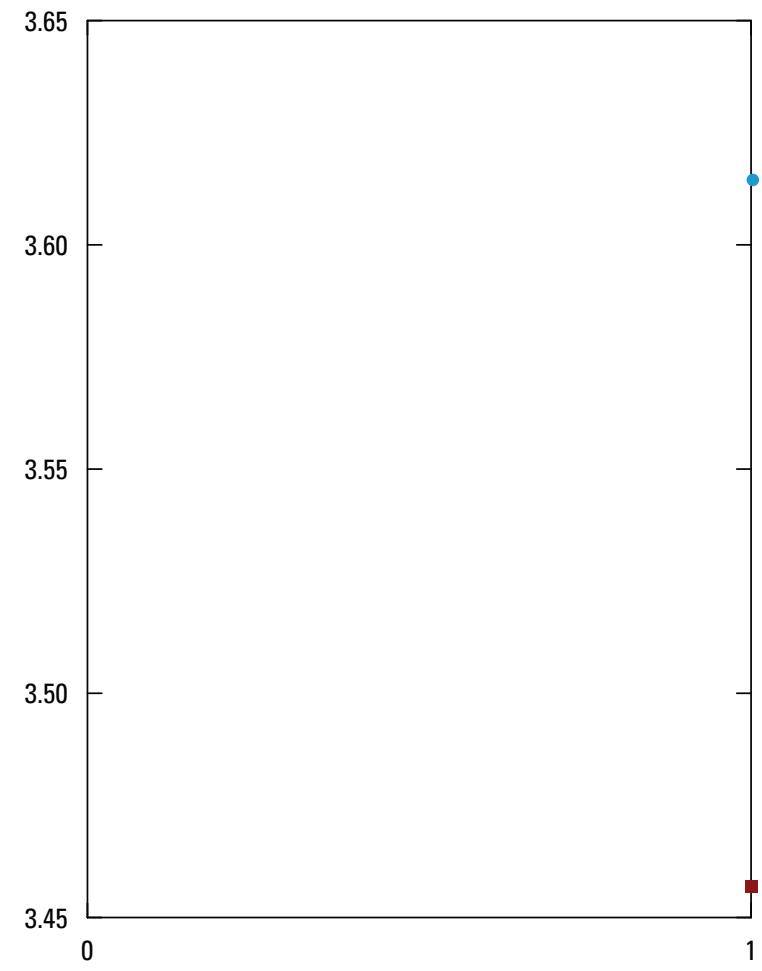

Figure 6-5. Initial uncoupled calibration results for one-year streamgage 054066491, Garfoot Creek near Cross Plains, for $A$, the $\log$ of daily streamflow; $B$, mean annual streamflow; and $C$, monthly mean streamflow. Blue lines represent observed data; red lines and symbols are the PRMS-only model-simulated equivalent quantity. These results were interim results for calibration as these observations were included in the final fully coupled model calibration. 
A. Daily streamflow

Nash-Sutcliffe coefficient: 0.38

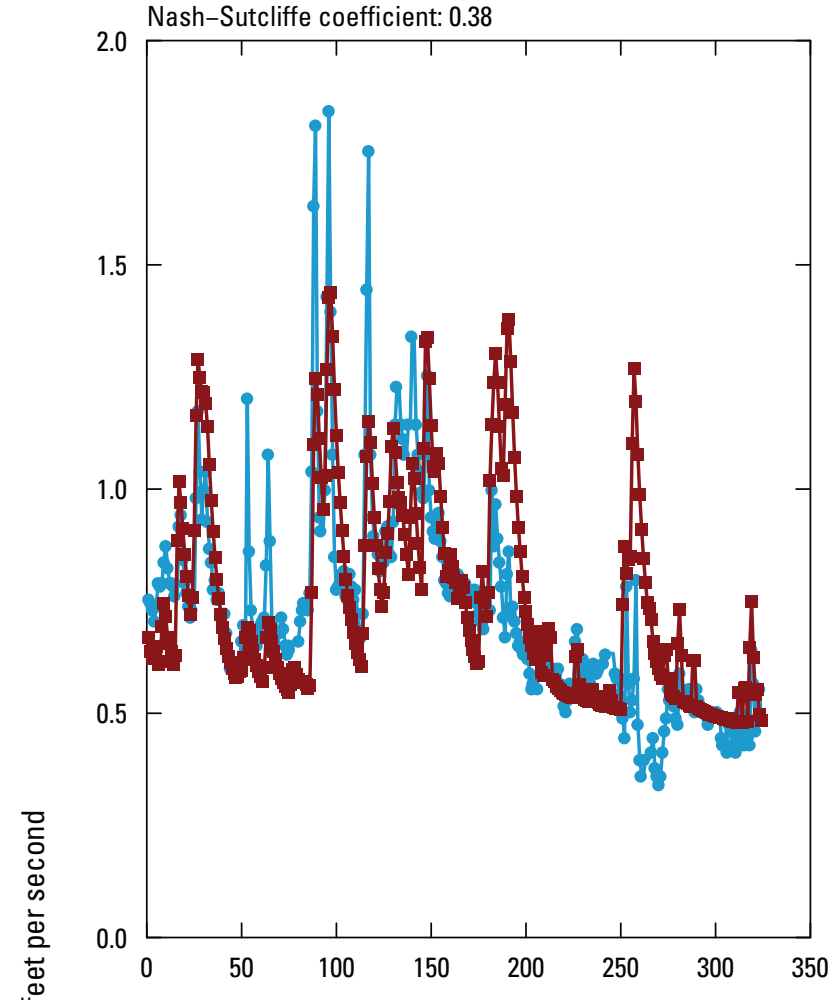

B. Annual mean streamflow

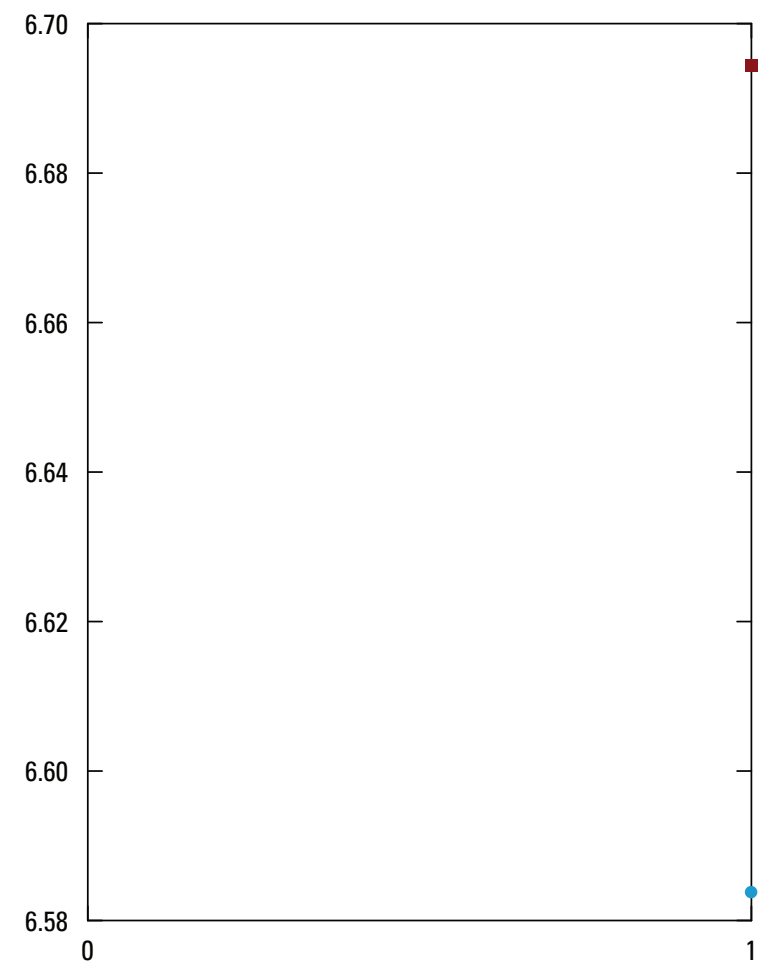

C. Monthly mean streamflow

Nash-Sutcliffe coefficient: 0.56

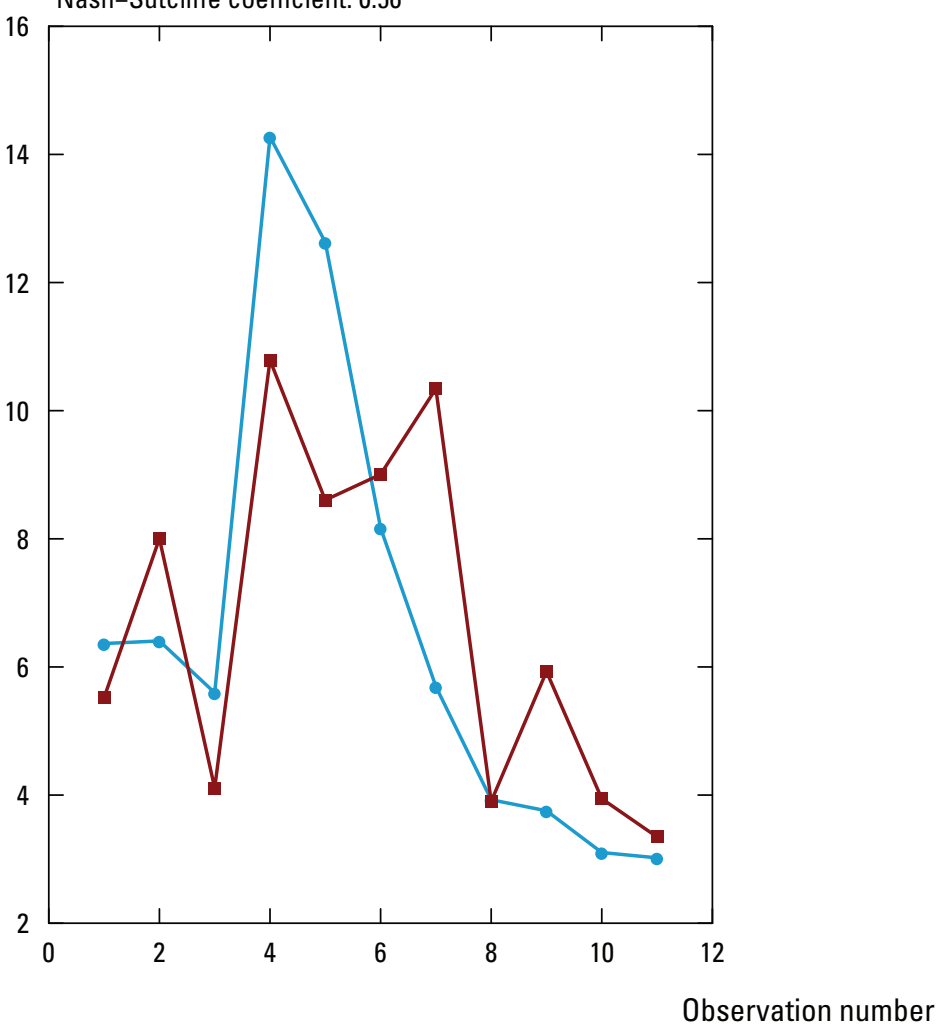

Figure 6-6. Initial uncoupled calibration results for one-year streamgage 054065145, Vermont Creek at Highway KP, for $A$, the $\log$ of daily streamflow; $B$, mean annual streamflow; and $C$, monthly mean streamflow. Blue lines represent observed data; red lines and symbols are the PRMS-only model-simulated equivalent quantity. These results were interim results for calibration as these observations were included in the final fully coupled model calibration. 
A. Daily streamflow

Nash-Sutcliffe coefficient: 0.29

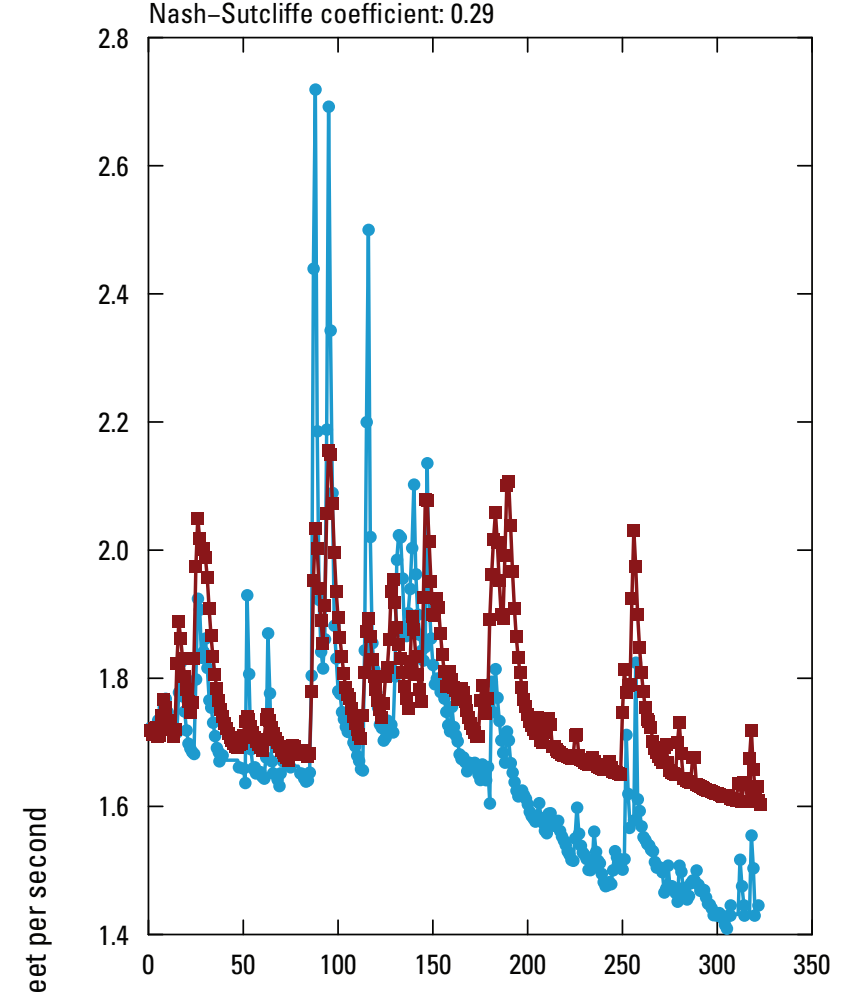

\section{B. Annual mean streamflow}

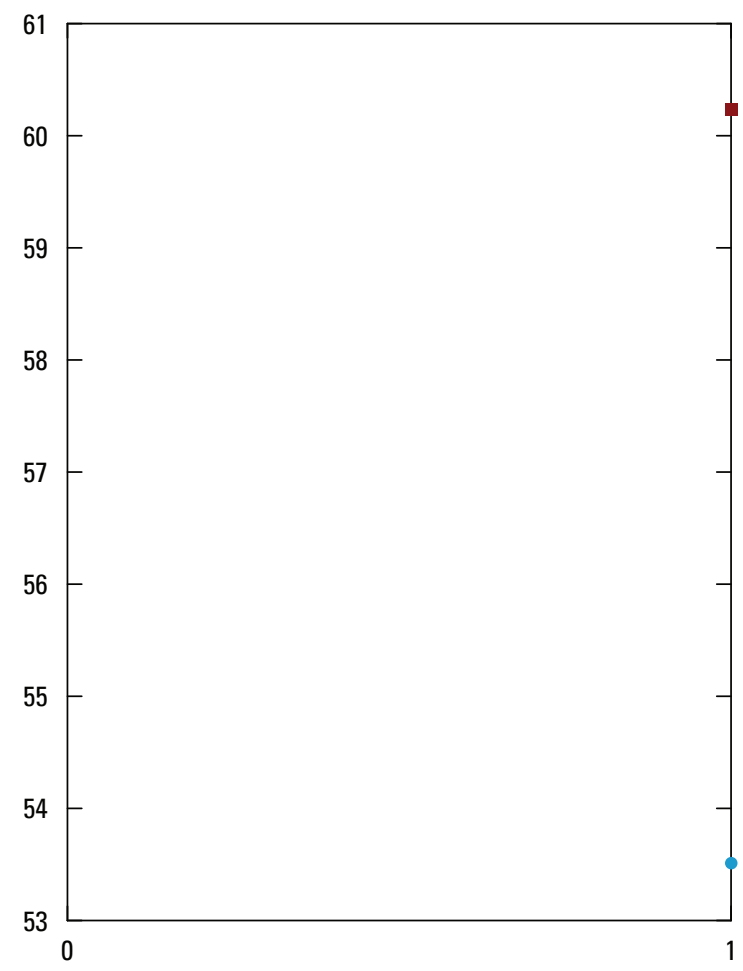

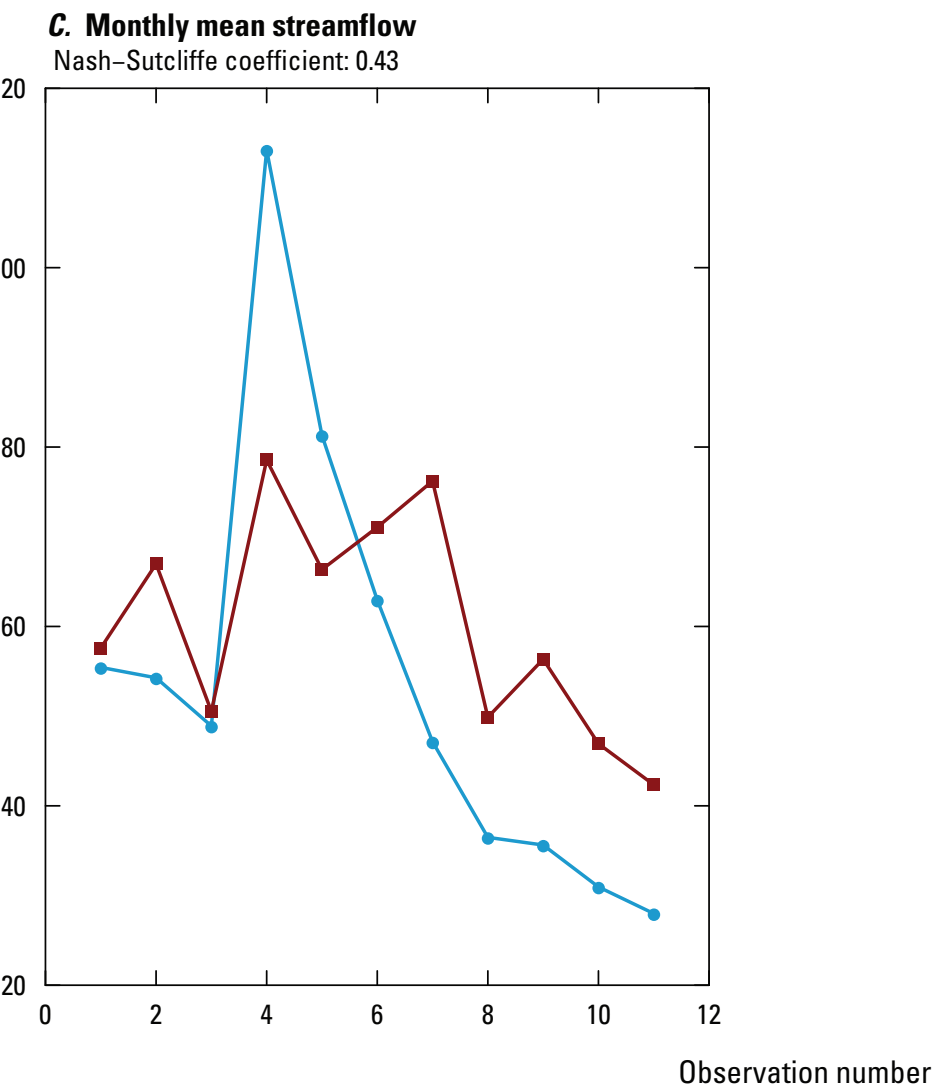

Figure 6-7. Initial uncoupled calibration results for one-year streamgage 05406540 , Black Earth Creek at Mazomanie, for $A$, the $\log$ of daily streamflow; $B$, mean annual streamflow; and $C$, monthly mean streamflow. Blue lines represent observed data; red lines and symbols are the PRMS-only model-simulated equivalent quantity. These results were interim results for calibration as these observations were included in the final fully coupled model calibration. 
Table 6-1. MODFLOW-only head calibration statistics. Error residual statistics or differences are calculated as observed minus simulated value.

[ft, feet above National Geodetic Vertical Datum of 1929 (geodetic datum)]

\begin{tabular}{lr}
\hline \multicolumn{2}{c}{ Head calibration (183 targets) } \\
\hline Mean error (ft) & 0.78 \\
Mean absolute error (ft) & 10.39 \\
Root mean squared error (ft) & 14.73 \\
Maximum residual & 55.42 \\
Minimum residual & -58.70 \\
\hline
\end{tabular}

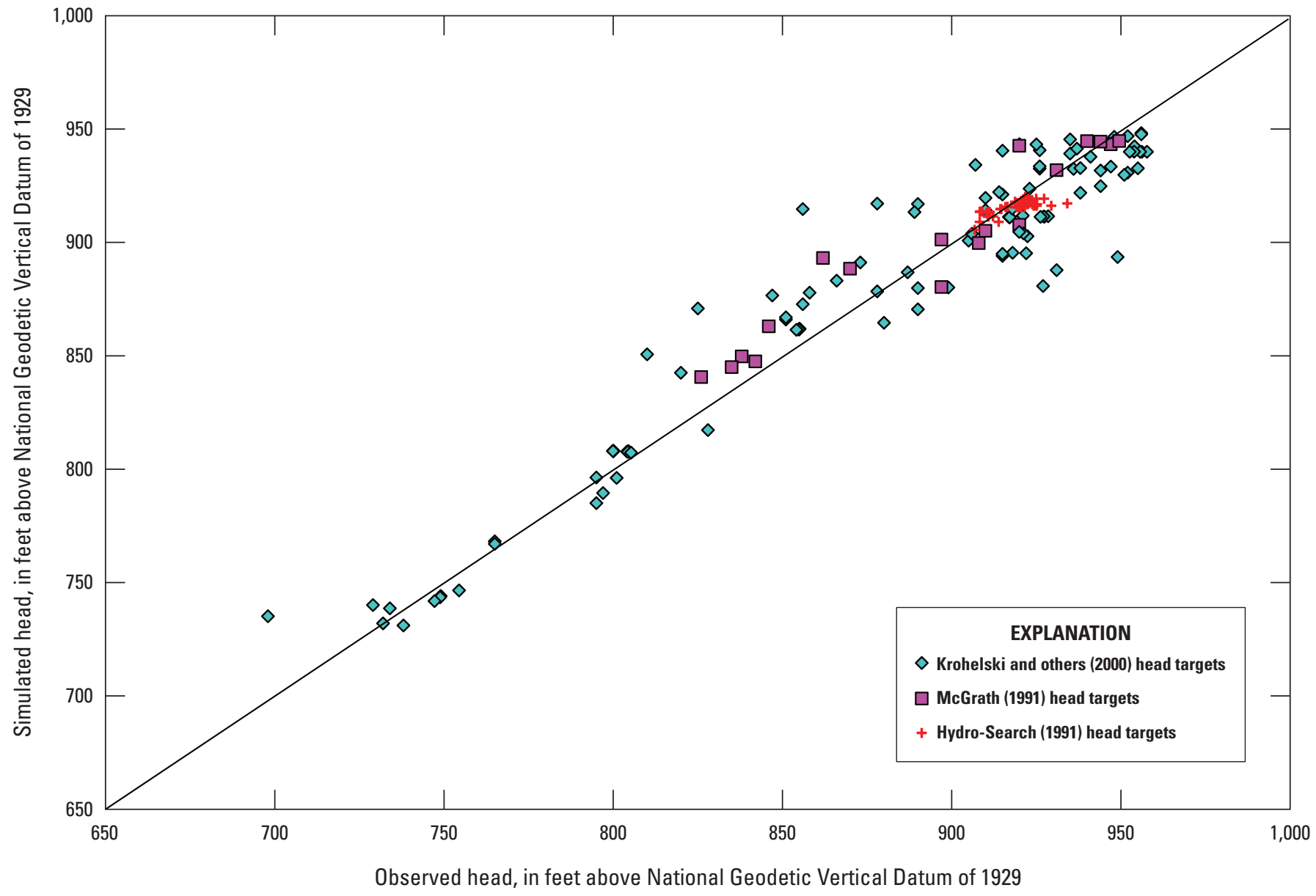

Figure 6-8. Observed heads compared to heads simulated by the optimal MODFLOW-only model. 


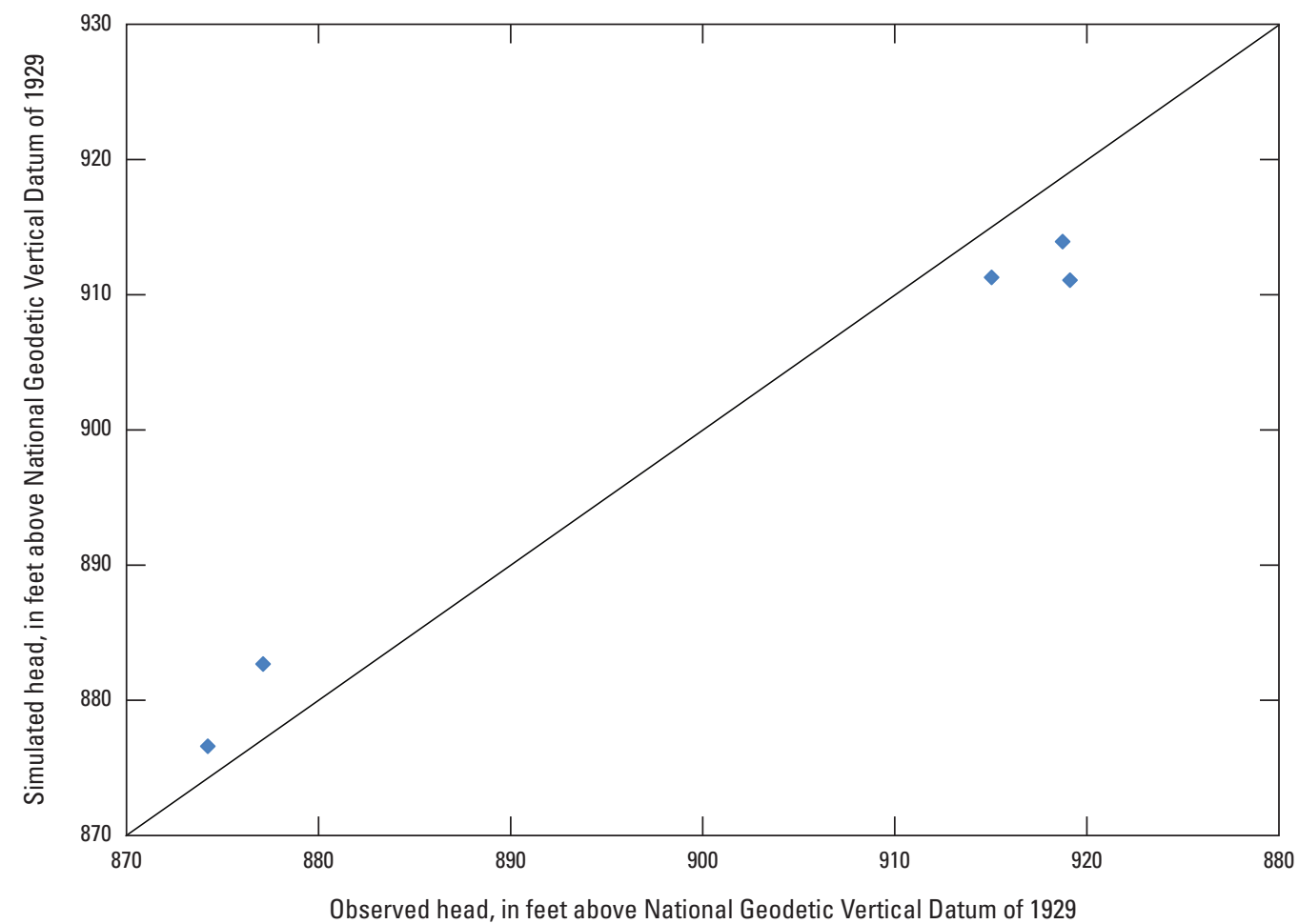

Figure 6-9. Heads measured in 2005 (appendix 5) compared to heads simulated by the optimal MODFLOW-only model. These head targets are used for calibration of the fully coupled model (fig. $6-23)$.

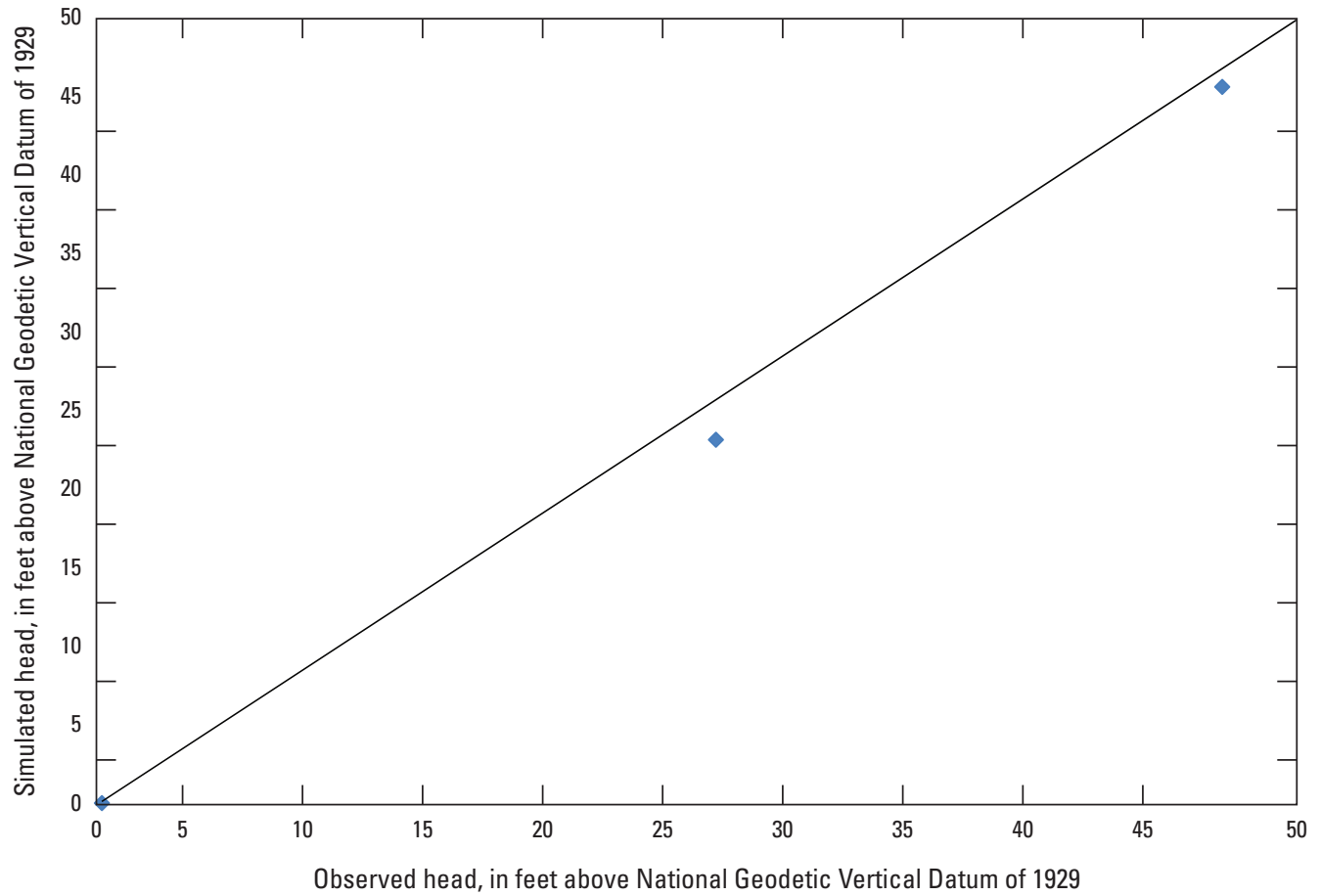

Figure 6-10. Vertical head differences calculated using observed heads compared to vertical head differences calculated using heads simulated by the optimal MODFLOW-only model. 


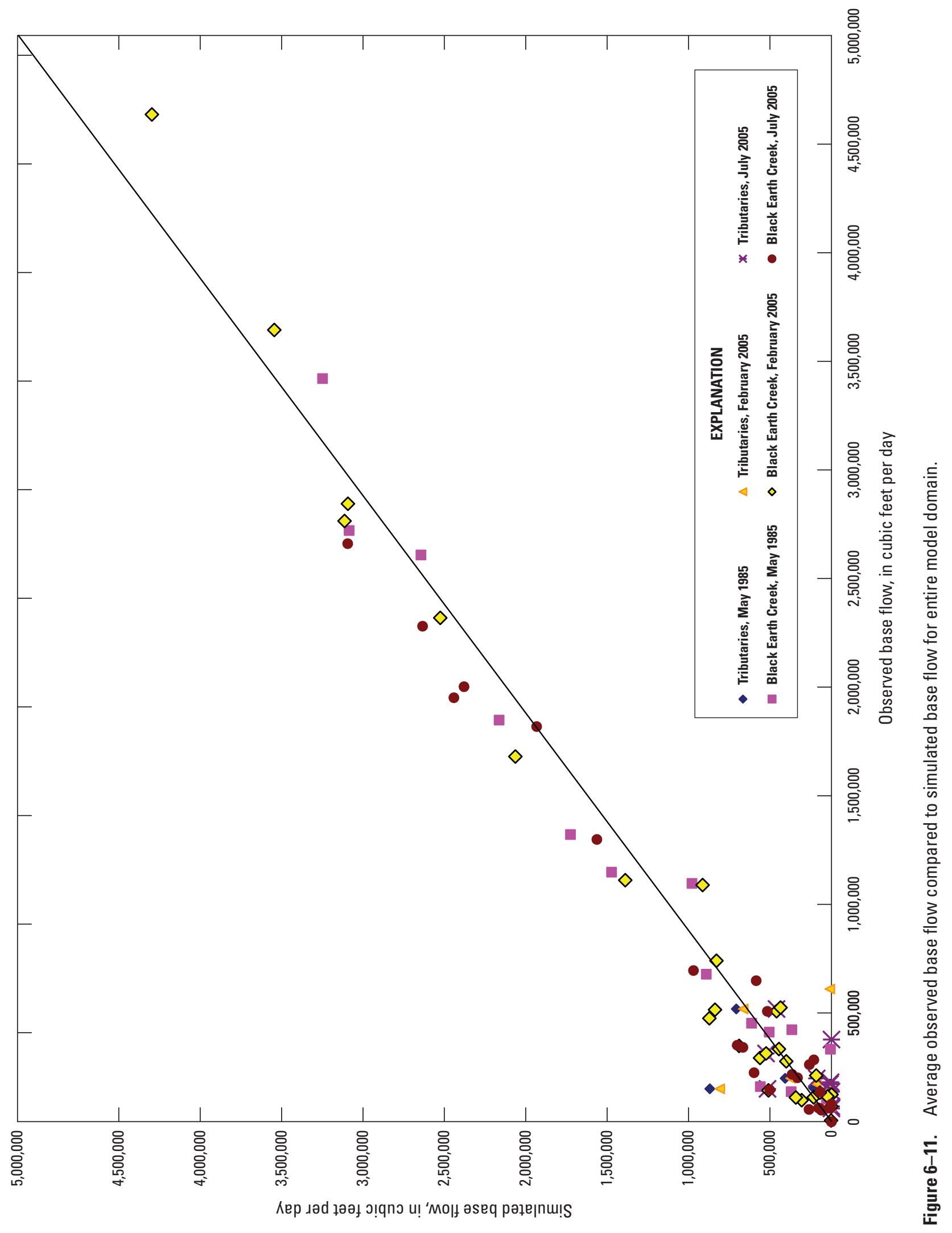




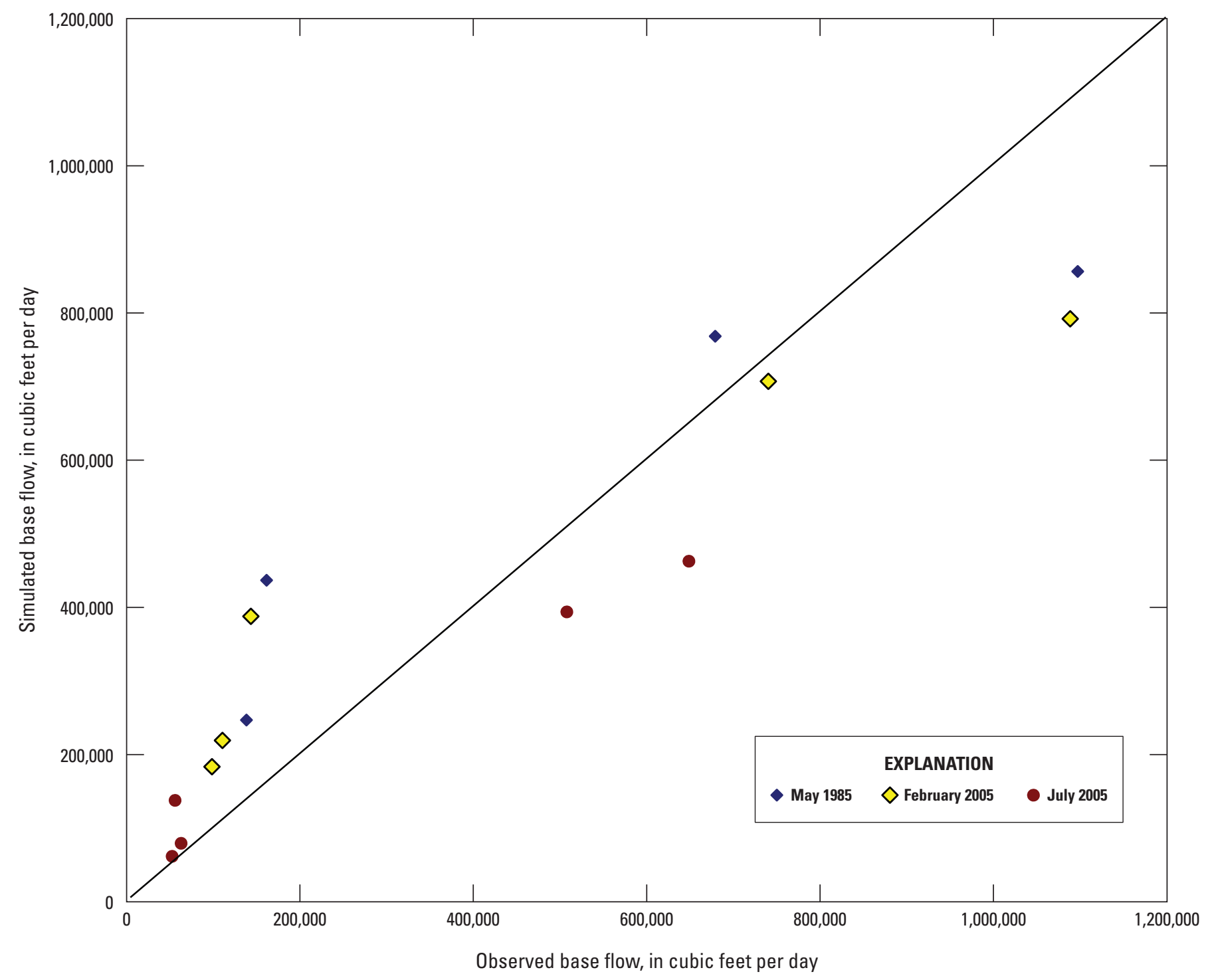

Figure 6-12. Average observed base flow compared to simulated base flow for Black Earth Creek headwater locations. 


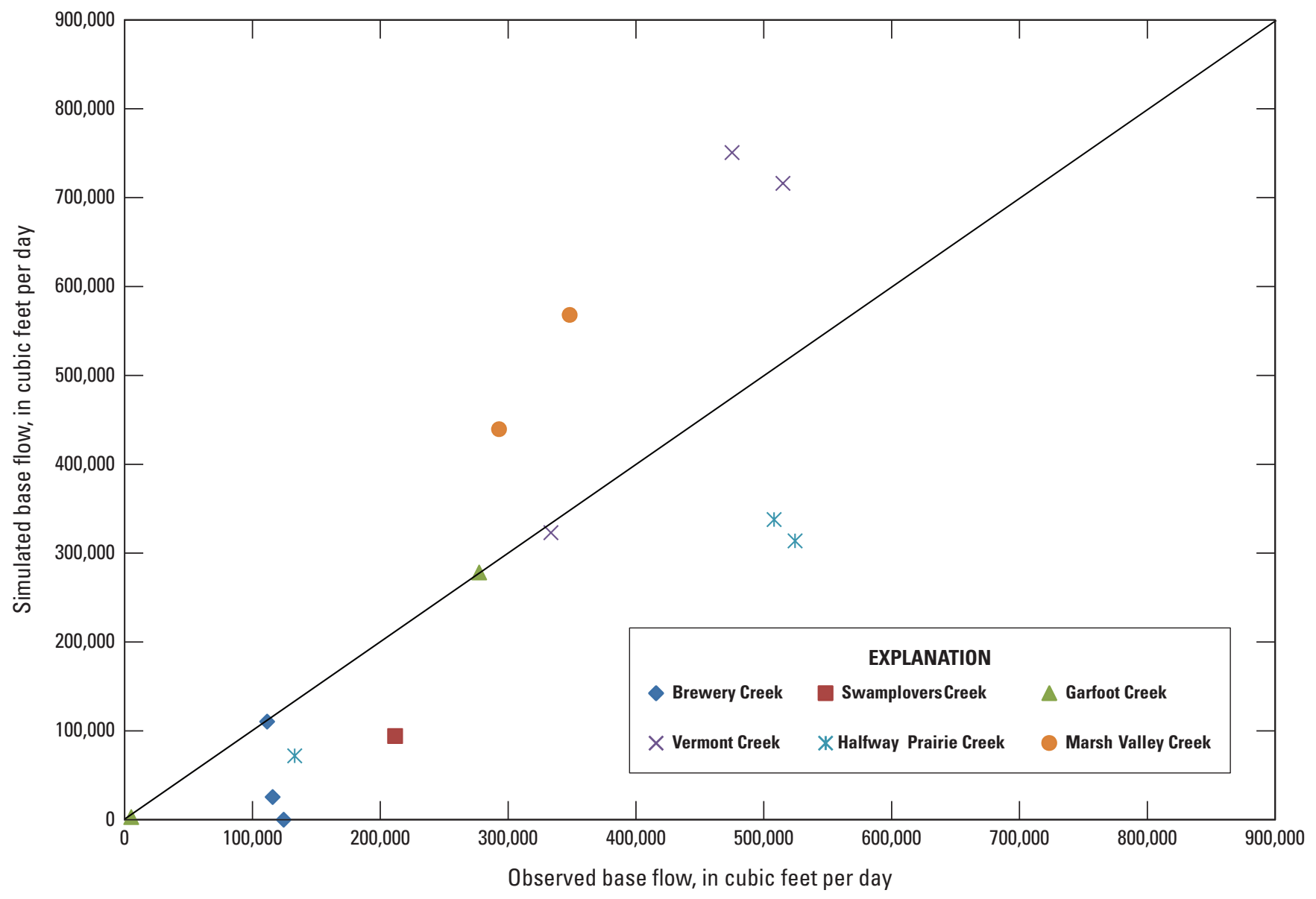

Figure 6-13. February 2005 observed base flow compared to simulated base flow for tributaries of Black Earth Creek. 


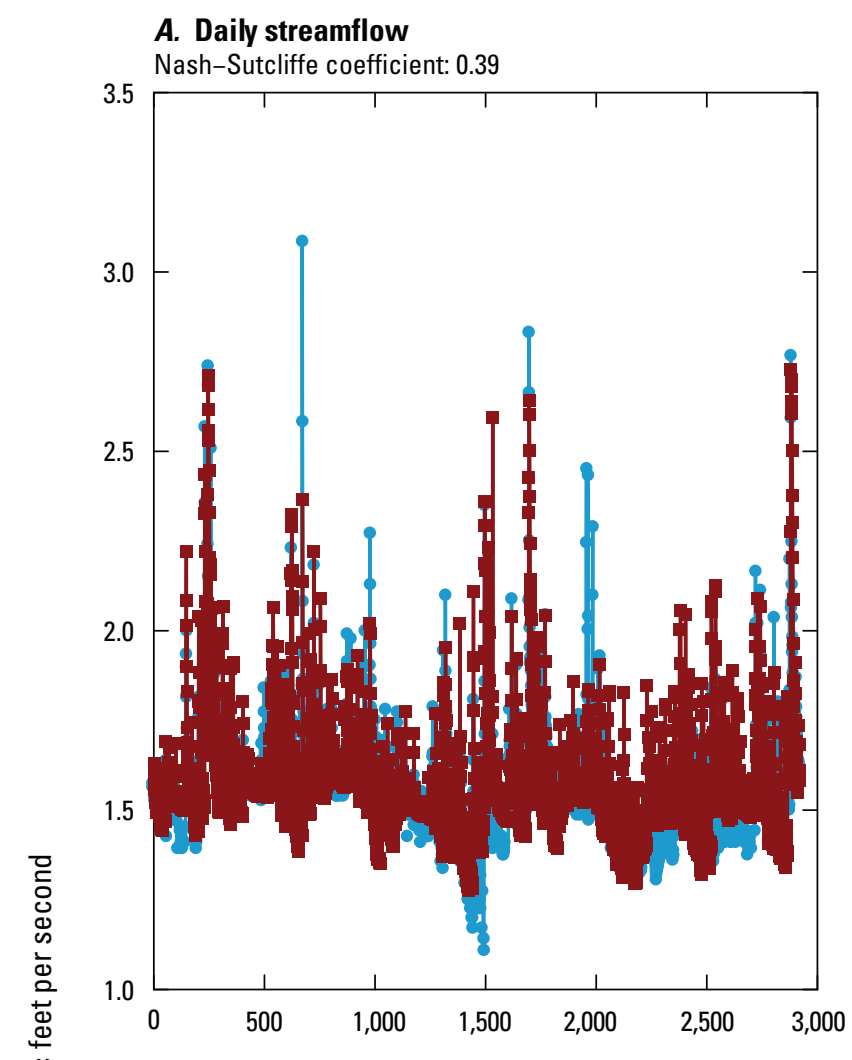

\section{B. Annual mean streamflow}
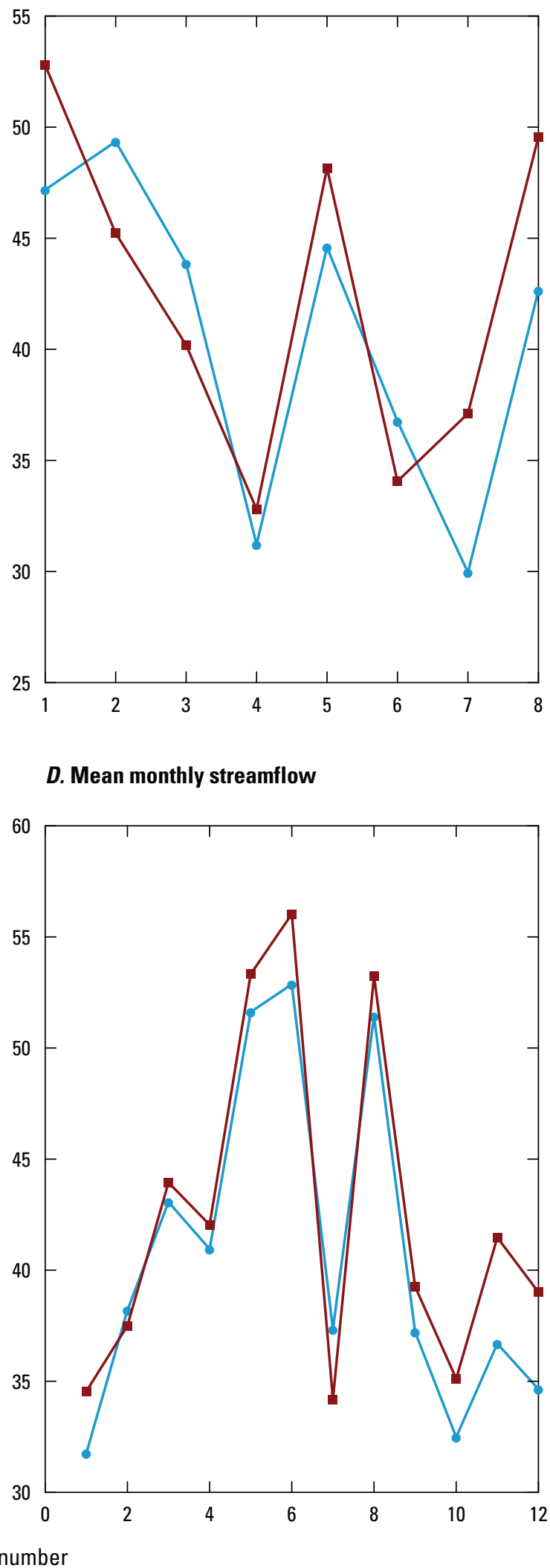

Figure 6-14. Calibration results for long-term streamgage 05406500, Black Earth Creek at Black Earth, for $A$, the log of daily streamflow; $B$, mean annual streamflow; $C$, monthly mean streamflow; and $D$, mean monthly streamflow calculated for 8 years of record. Blue lines represent observed data; red lines and symbols are the fully coupled model-simulated equivalent quantity. This location has the longest record in the basin, thus was given high importance during calibration. 
A. Daily streamflow

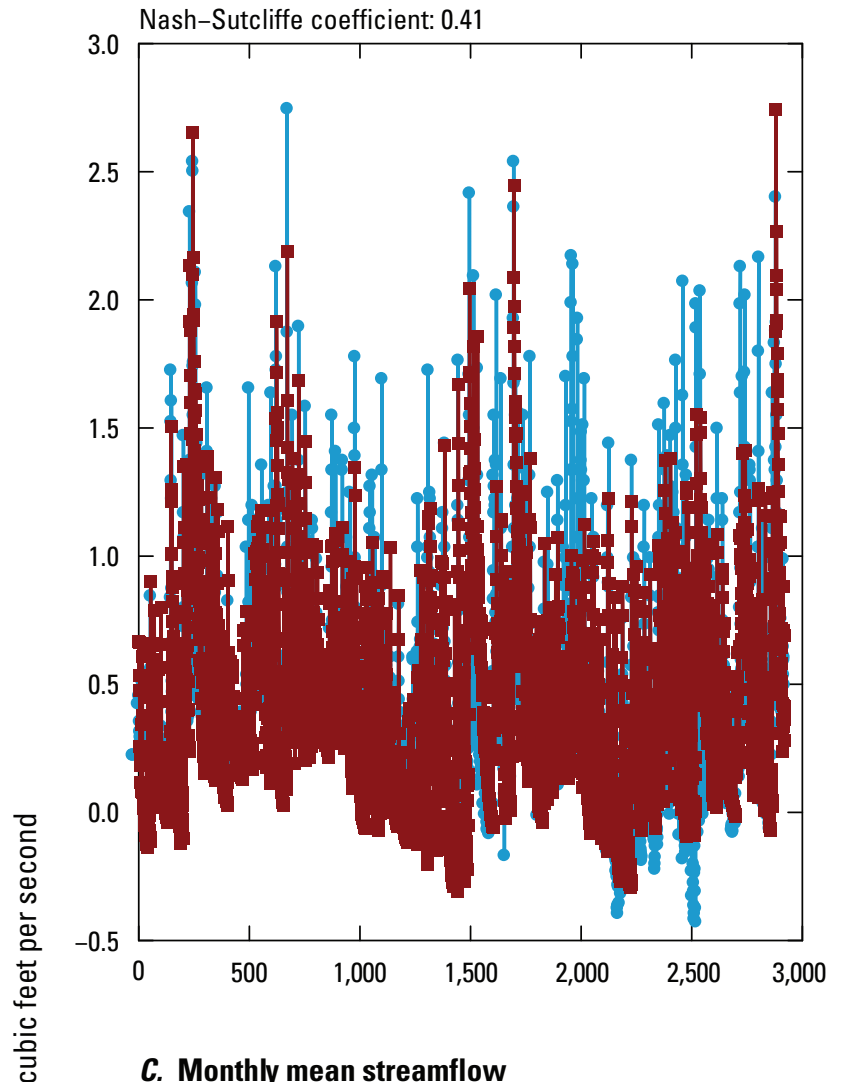

Nash-Sutcliffe coefficient: 0.68

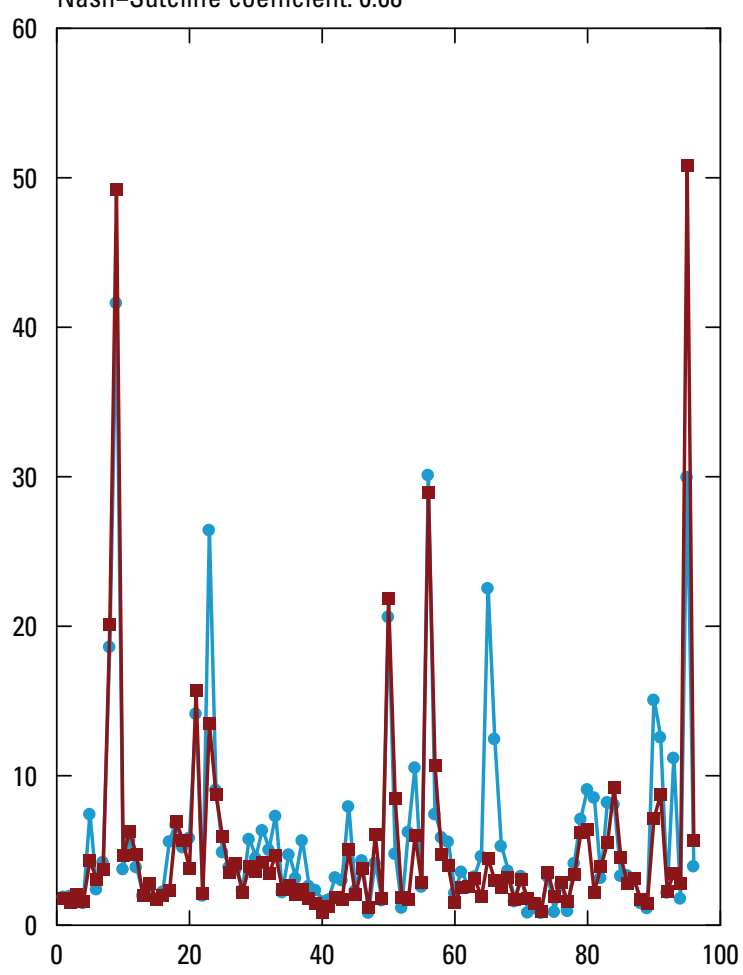

\section{B. Annual mean streamflow}

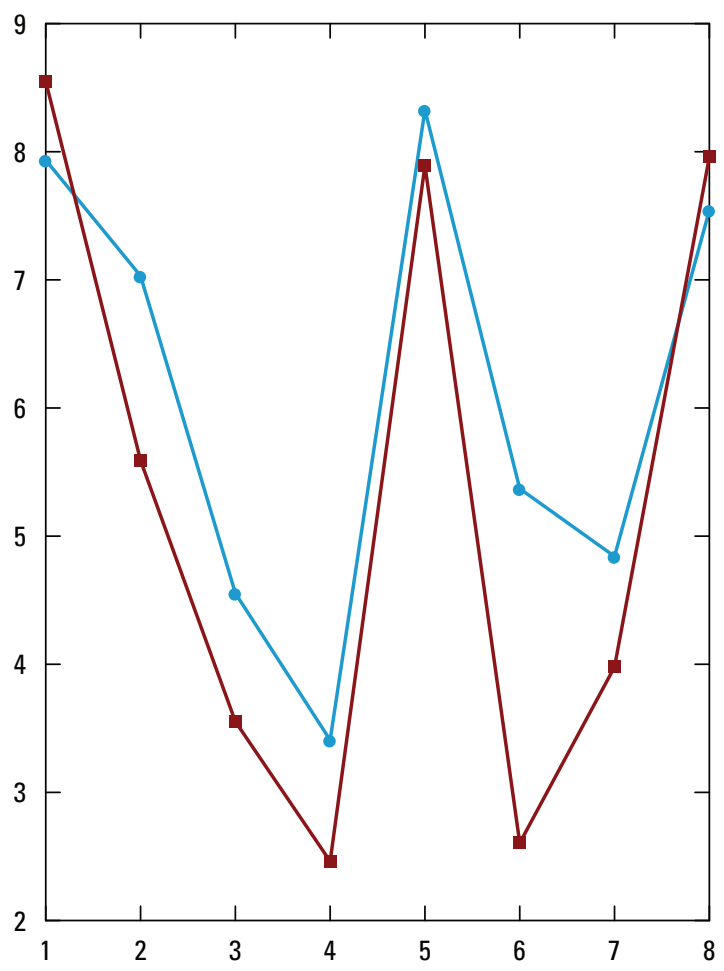

D. Mean monthly streamflow

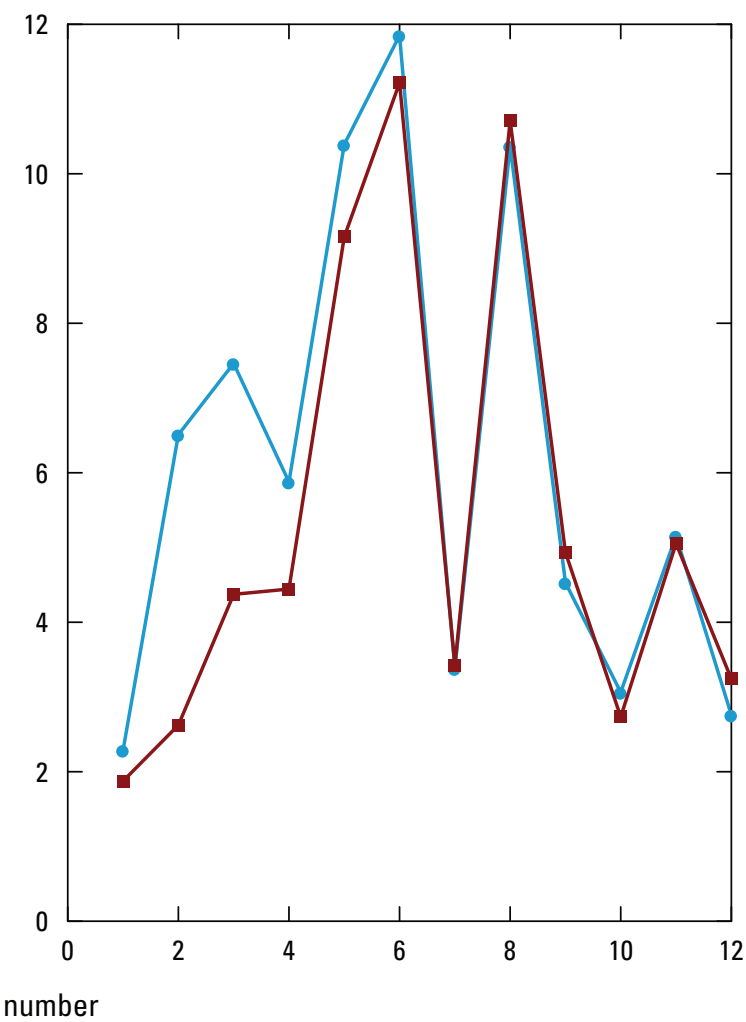

Figure 6-15. Calibration results for long-term streamgage 05427948, Pheasant Branch at Middleton, for $A$, the log of daily streamflow; $B$, mean annual streamflow; $C$, monthly mean streamflow; and $D$, mean monthly streamflow calculated for 8 years of record. Blue lines represent observed data; red lines and symbols are the fully coupled model-simulated equivalent quantity. 


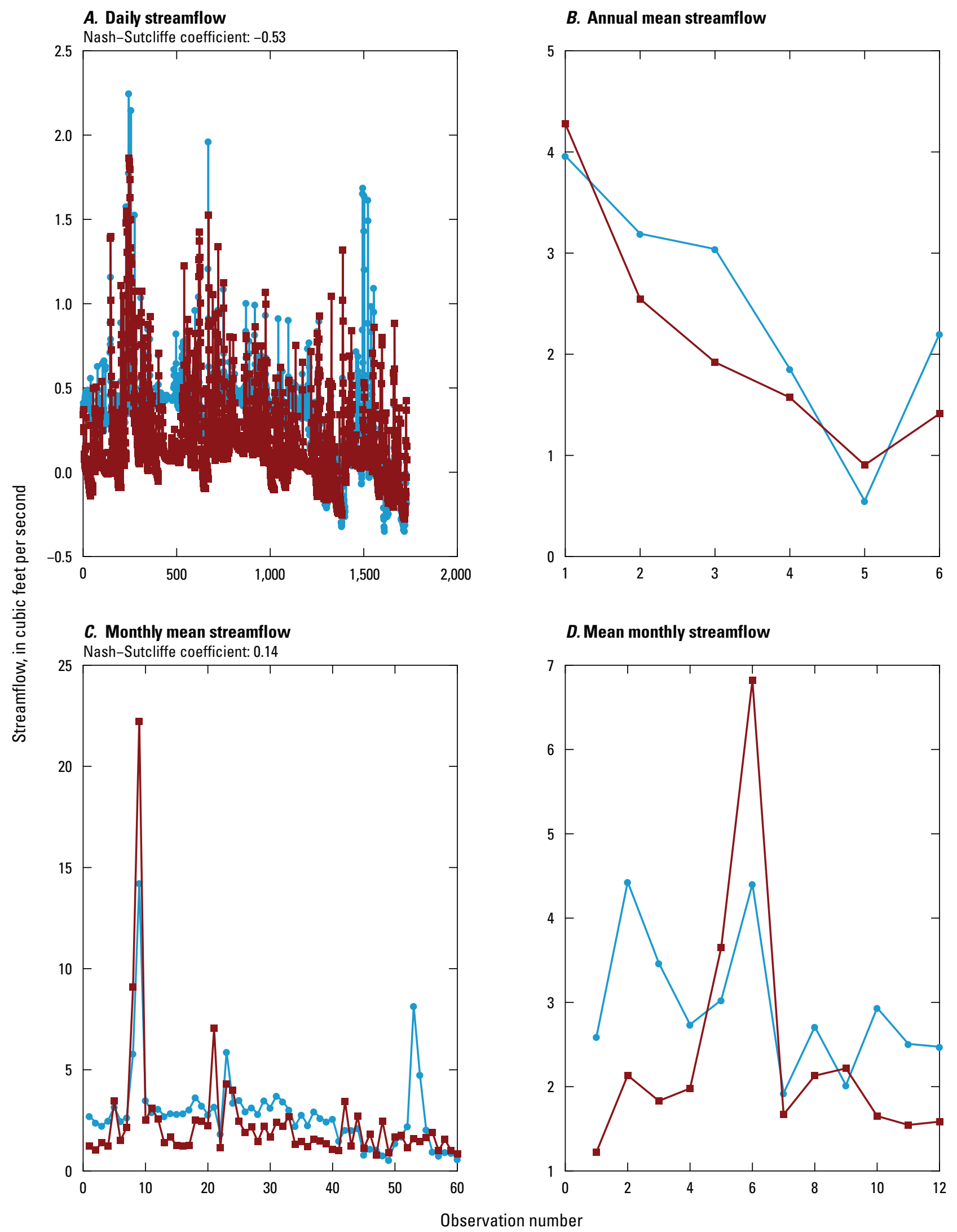

Figure 6-16. Calibration results for long-term streamgage 05406470, Brewery Creek at Cross Plains, for $A$, the log of daily streamflow; $B$, mean annual streamflow; $C$, monthly mean streamflow; and $D$, mean monthly streamflow calculated for 8 years of record. Blue lines represent observed data; red lines and symbols are the fully coupled model-simulated equivalent quantity. 


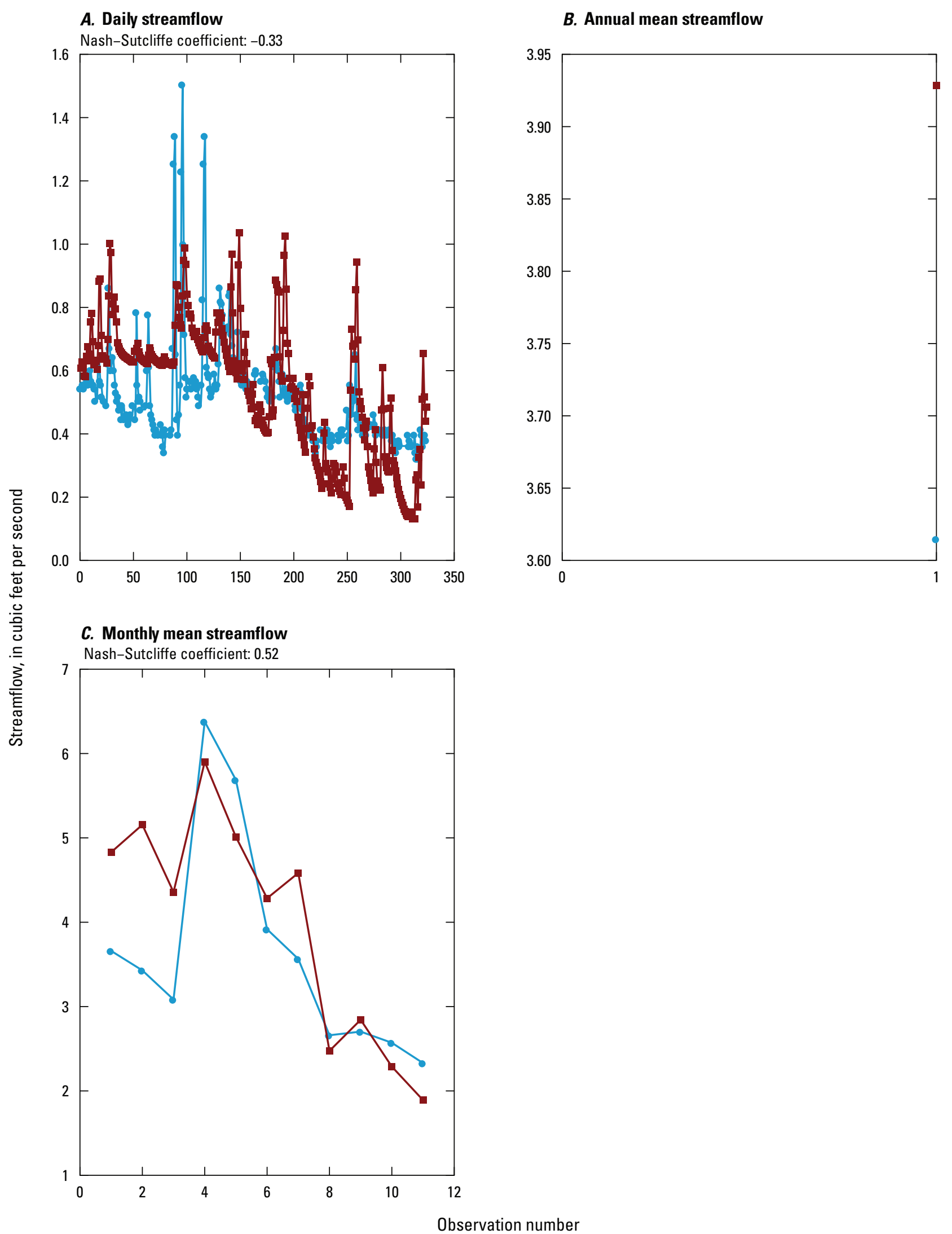

Figure 6-17. Calibration results for 1-year streamgage 05406491, Garfoot Creek near Cross Plains, for $A$, the log of daily streamflow; $B$, mean annual streamflow; and $C$, monthly mean streamflow. Blue lines represent observed data; red lines and symbols are the fully coupled model-simulated equivalent quantity. 


\section{A. Daily streamflow}

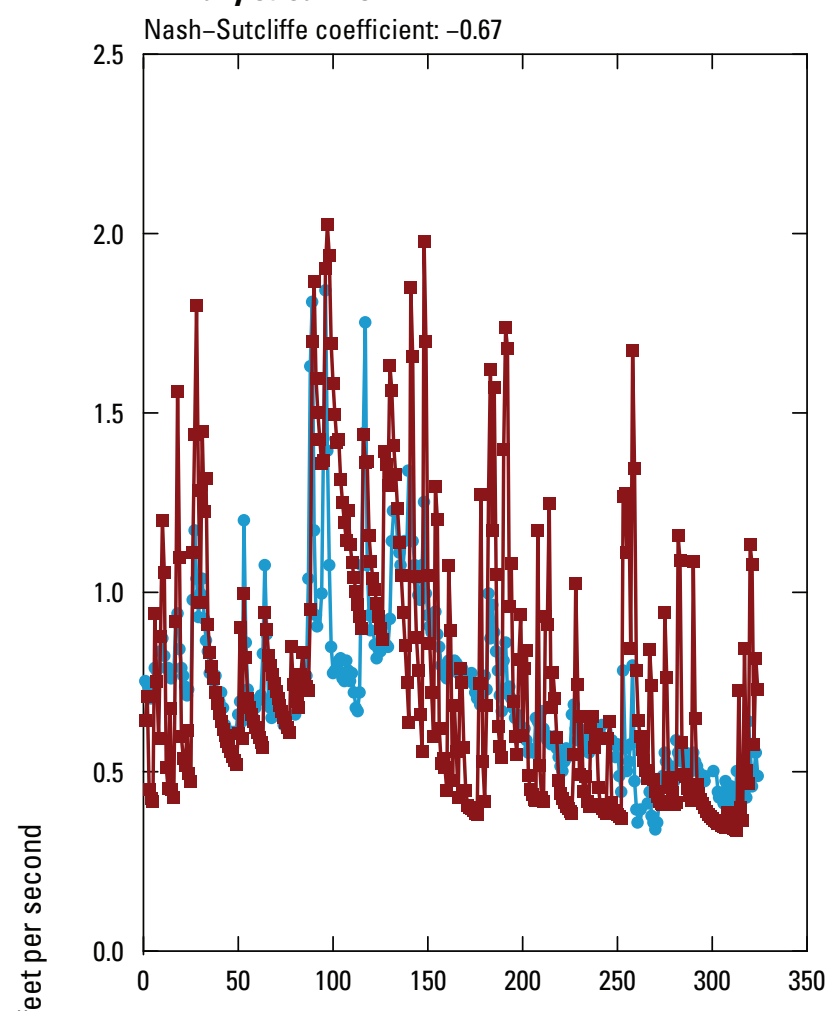

B. Annual mean streamflow

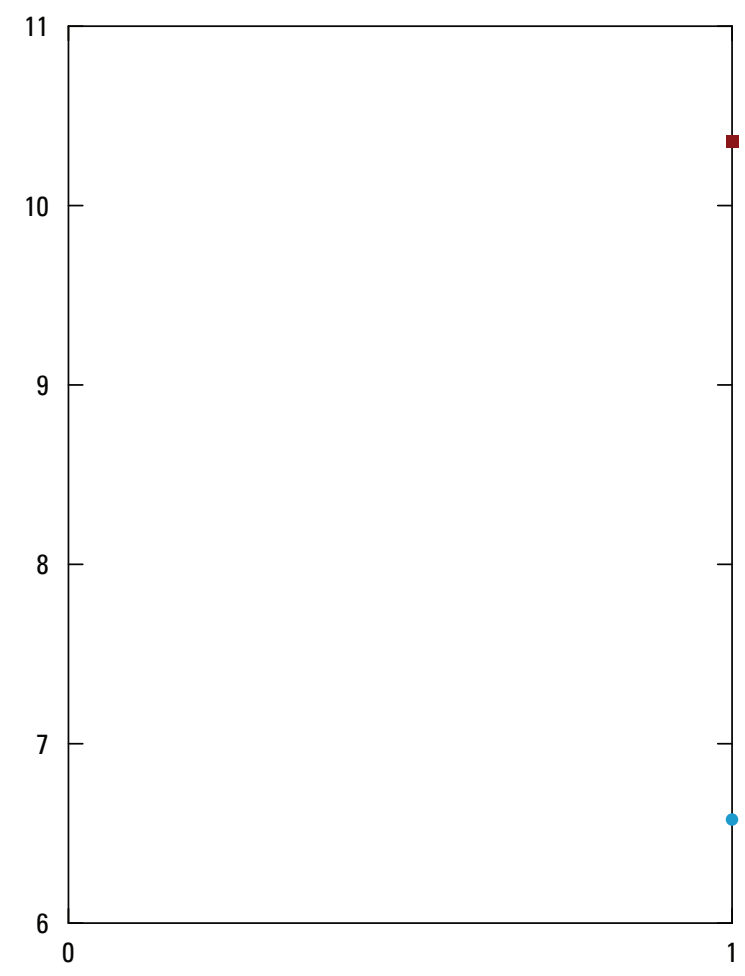

\section{Monthly mean streamflow}

Nash-Sutcliffe coefficient: -1.7

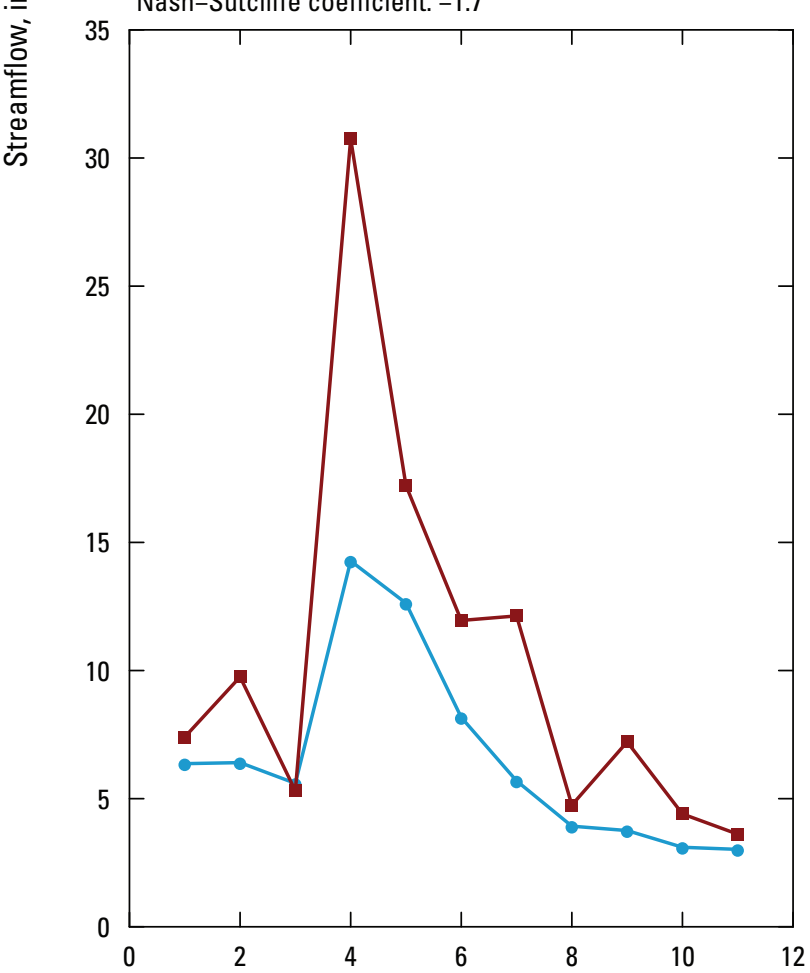

Observation number

Figure 6-18. Calibration results for 1-year streamgage 054065145, Vermont Creek near Highway KP, for $A$, the log of daily streamflow; $B$, mean annual streamflow; and $C$, monthly mean streamflow. Blue lines represent observed data; red lines and symbols are the fully coupled model-simulated equivalent quantity. 


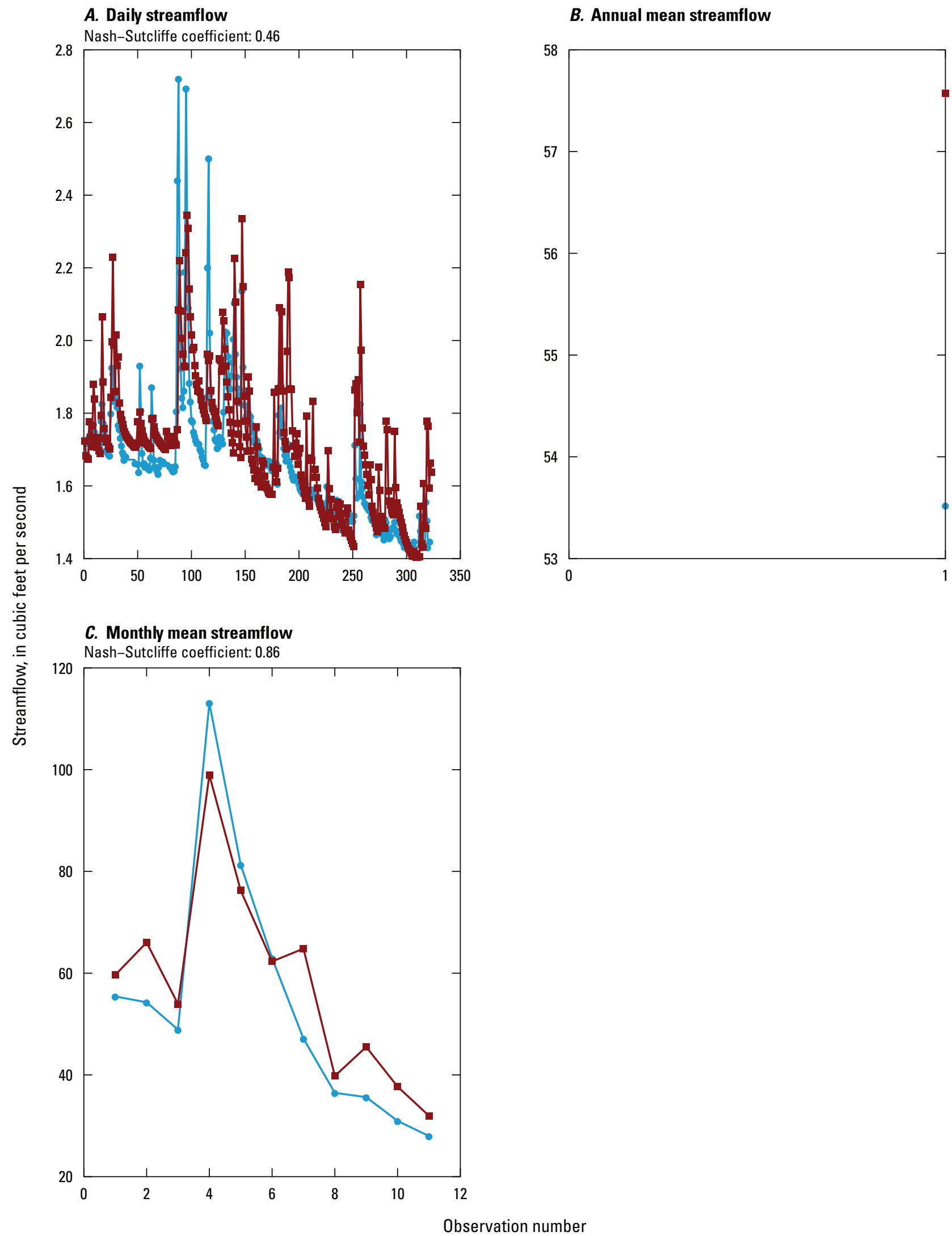

Figure 6-19. Calibration results for 1-year streamgage 05406540, Black Earth Creek at Mazomanie, for $A$, the log of daily streamflow; $B$, mean annual streamflow; and $C$, monthly mean streamflow. Blue lines represent observed data; red lines and symbols are the fully coupled model-simulated equivalent quantity. This location reflects the most downstream observation for the Black Earth Creek watershed. 
Simulated groundwater levels were generally similar to timing and magnitudes of observed trends in groundwater levels (figs. 6-20 through 6-22) and mean groundwater level (fig. 6-23A). Because the number of head targets was so few, plots of spatial residuals are not shown. The range of variation in groundwater levels (fig. 6-23B) was systematically lower than that in the observed data, probably a result of spatial averaging over the nodal scale and temporal daily averaging of actual climate and soil-zone processes operating on a subdaily timescale. This type of spatial averaging should have less of an effect on observations that integrate many nodes (such as streamflow) than on observations involving responses at the node or subnode scale (such as groundwater levels at an individual well). Finally, the slightly lower simulated groundwater dynamics also may result from using a homogeneous unsaturated zone for the model, which precludes preferential flowpaths that can short-circuit the more homogenous matrix. The poorest simulation of dynamics at the Mount Simon deep well indicates a structural issue with the model making the perimeter boundary conditions static during the simulation period and with the model's representation of the interconnection between the upper and lower aquifers; the dynamic nature of the observed heads may reflect an interconnection between the aquifers that is not included in the model.

Initially, all aquifer hydraulic conductivity values were fixed at optimal values obtained during the MODFLOW-only calibration to reduce the number of parameters included in the long run times of the fully coupled model. However, to obtain an adequate fit during the final fully coupled calibration, layer-wide multipliers for the horizontal and vertical hydraulic conductivity of all six layers were included in the calibration. Multipliers on average changed little (multiplier $=1.02, n=12$ ) but a few individual multipliers changed appreciably (maximum, $\mathrm{K}_{\mathrm{v}}$ multiplier layer $2=2.4$; minimum, $\mathrm{K}_{\mathrm{v}}$ multiplier layer $4=0.47$ ). The resulting hydraulic conductivity fields are shown in figures 6-24 through 6-27. The result underscores the need to revise initial model conceptualizations and calibration approaches with the fully coupled model, even after calibration of the uncoupled models.

\section{A. Refuse Hideaway well 36s}

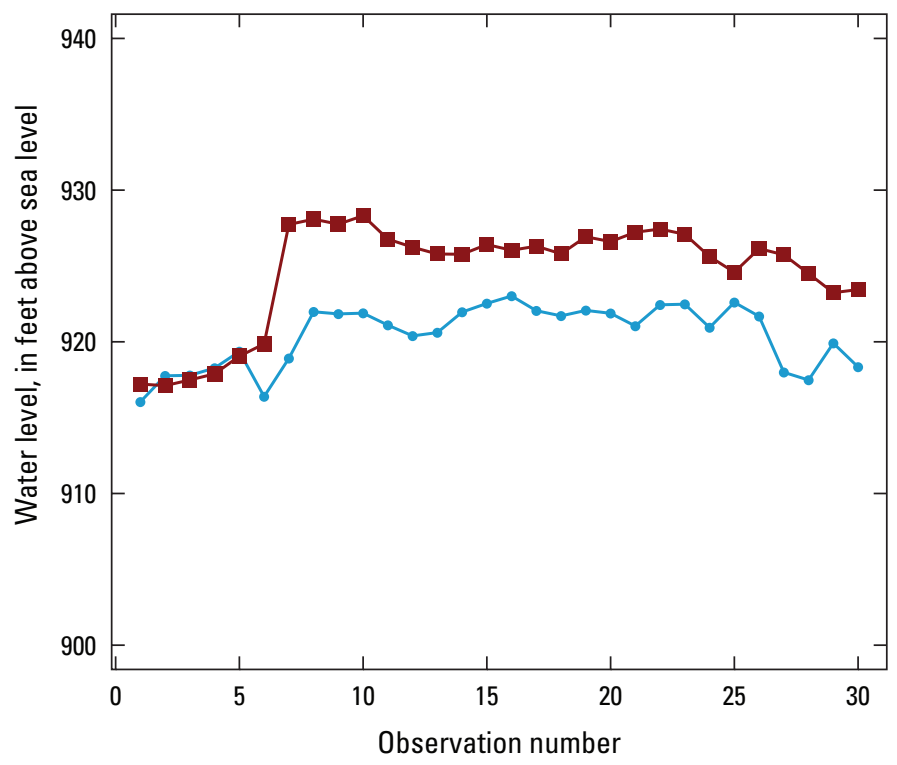

B. Refuse Hideaway well 36d

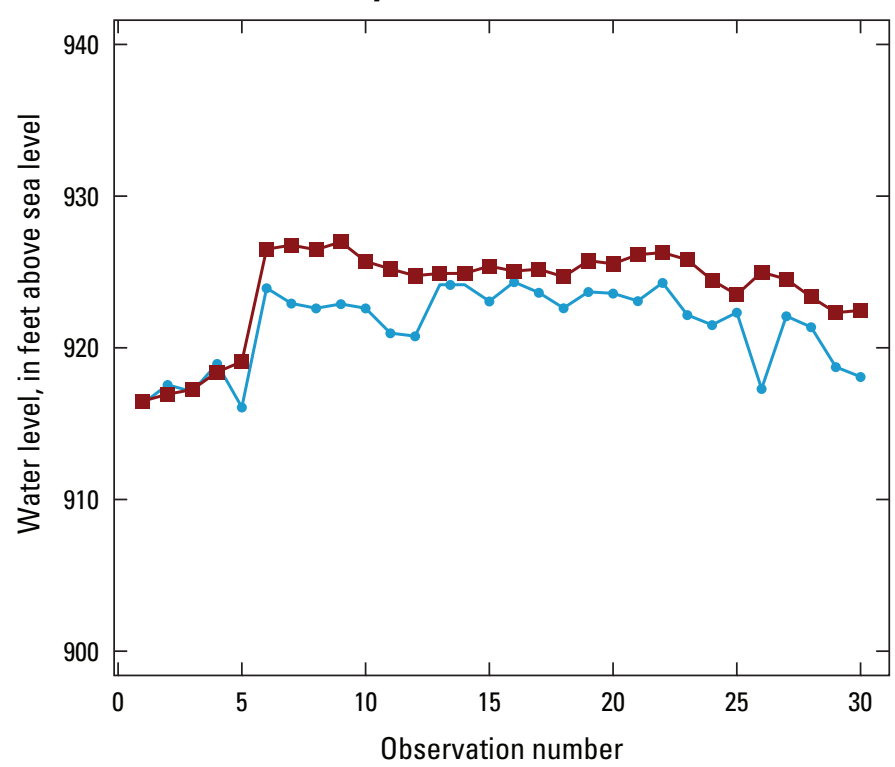

Figure 6-20. Calibration results for 1991-2006 at Refuse Hideaway wells $A, 36 \mathrm{~s}$; and B, 36d. Blue lines represent observed data; red lines and symbols are the fully coupled model-simulated equivalent quantity. 

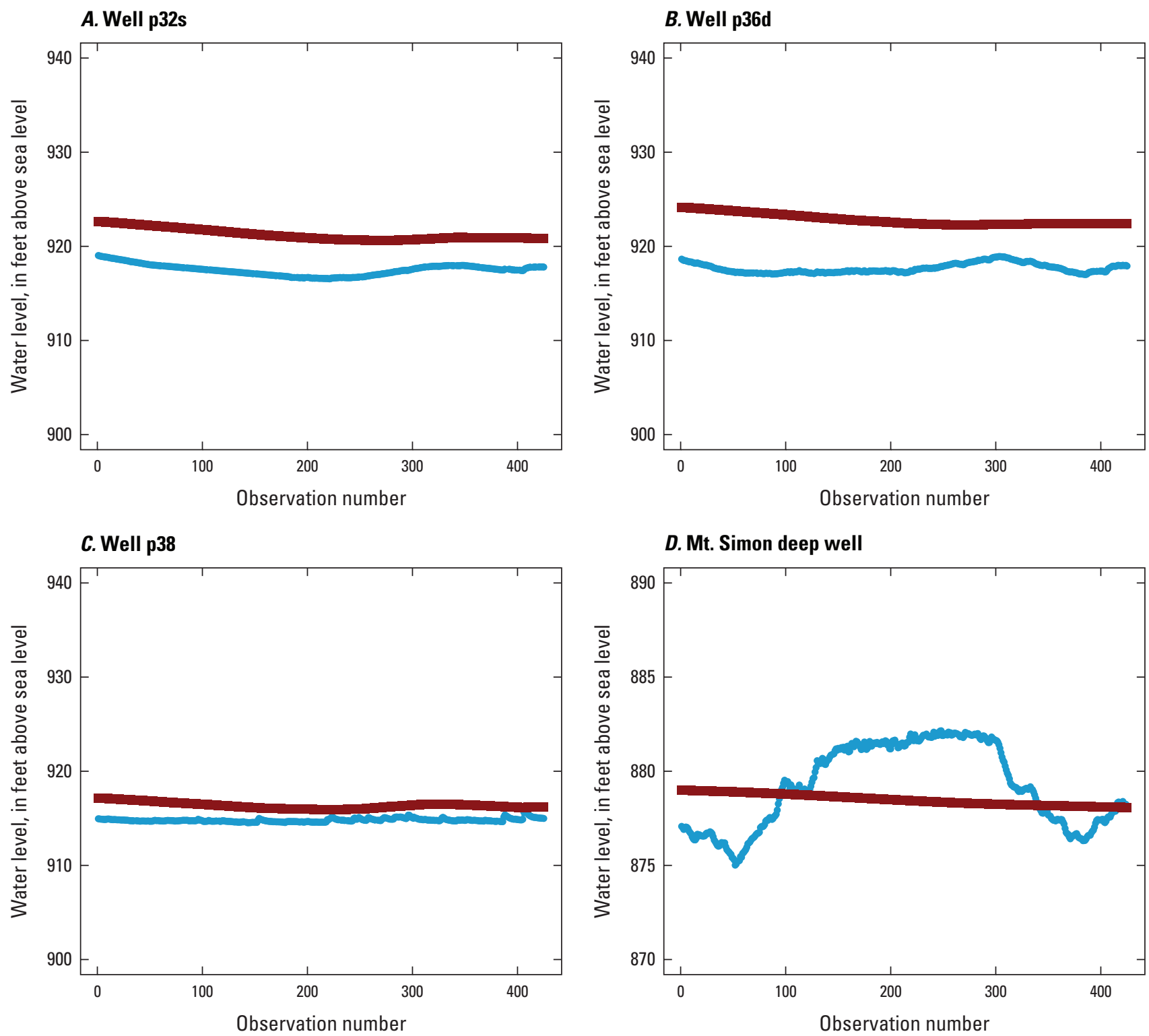

Figure 6-21. Calibration results for 2005-6 at Refuse Hideaway wells $A, 32 \mathrm{~s} ; B, 36 \mathrm{~d} ; C$, p38; and $D$, the Mount Simon deep well. Blue lines represent observed data; red lines and symbols are the fully coupled model-simulated equivalent quantity. 

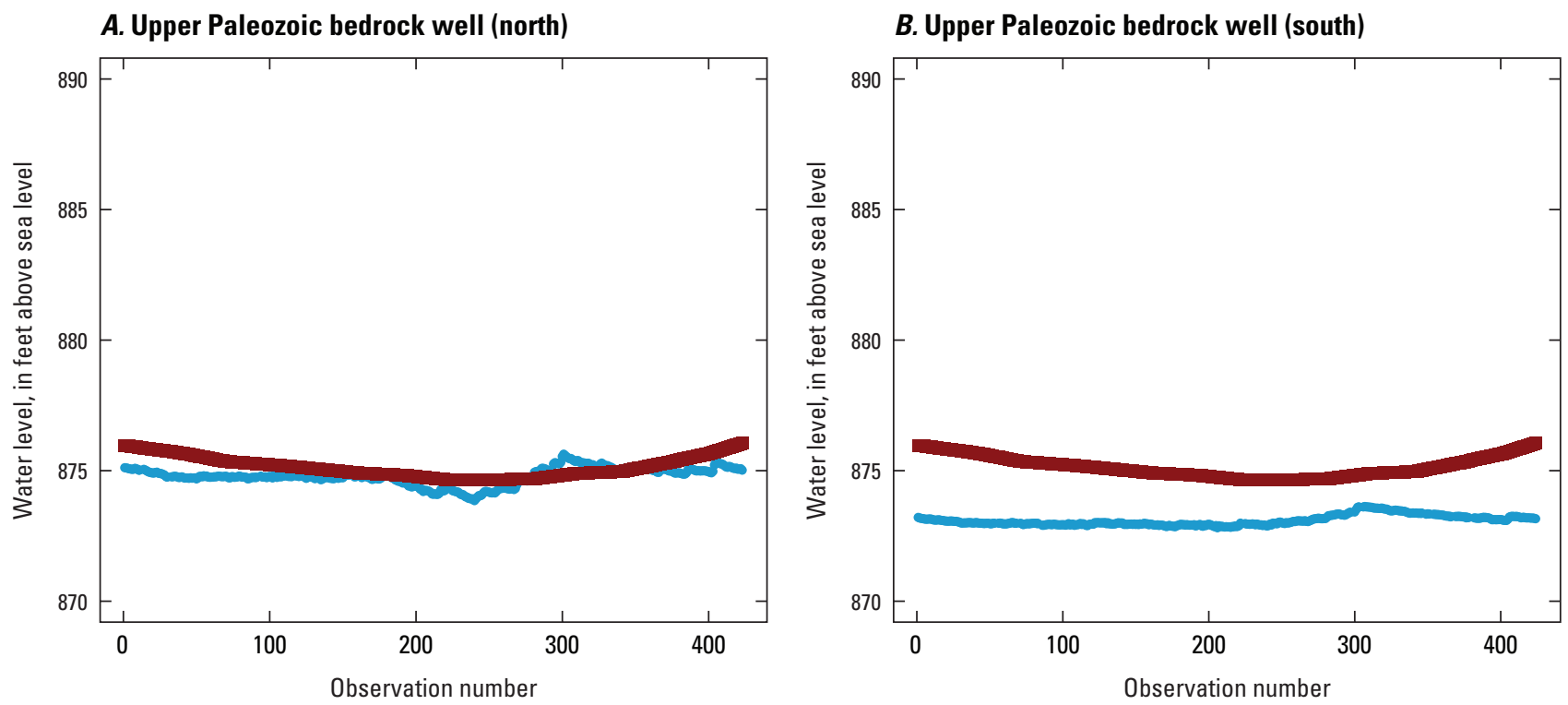

Figure 6-22. Calibration results for 2005-6 at Upper Paleozoic bedrock wells $A$, north and $B$, south. Blue lines represent observed data; red lines and symbols are the fully coupled model-simulated equivalent quantity.
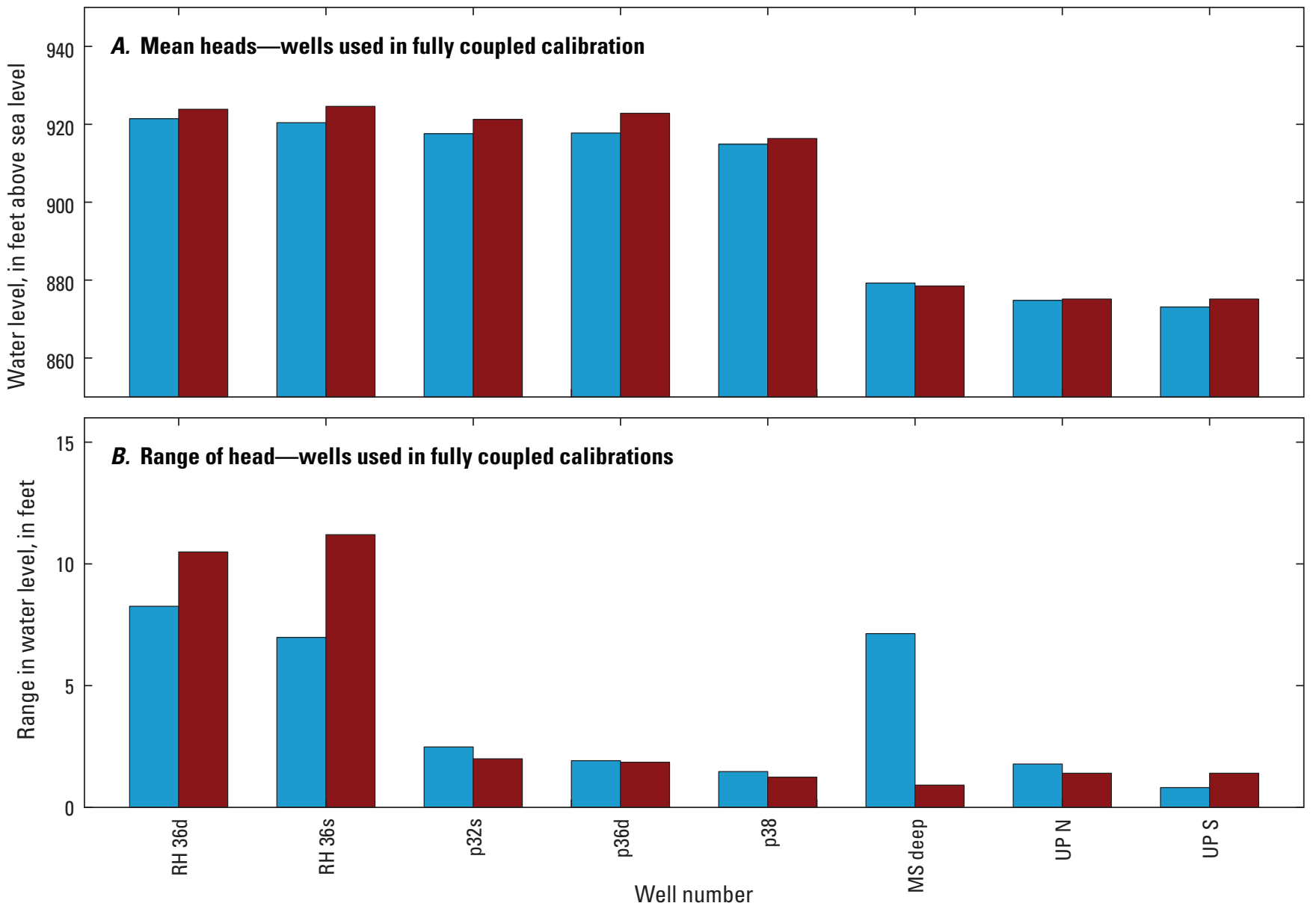

Figure 6-23. Mean water levels for the $A$, transient observed data; and $B$, range of water levels during the observation periods. Blue bars are observed data; red bars are the model-simulated equivalent quantity. 
A

WEST

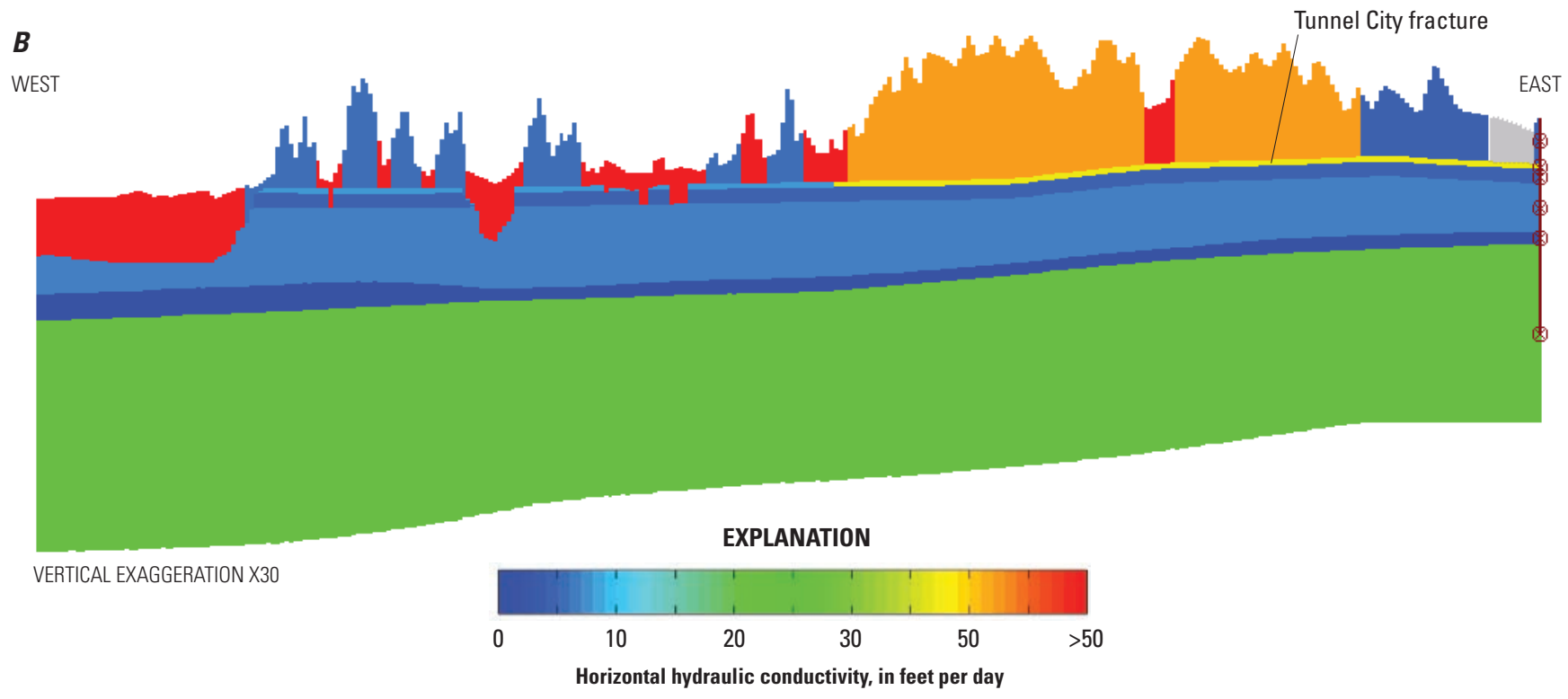

Figure 6-24. Horizontal hydraulic conductivity along Row 80 after fully coupled model calibration, shown as a cross section $A$, without vertical exaggeration, and $B$, with a vertical exaggeration of 30 .

$\boldsymbol{A}$

WEST

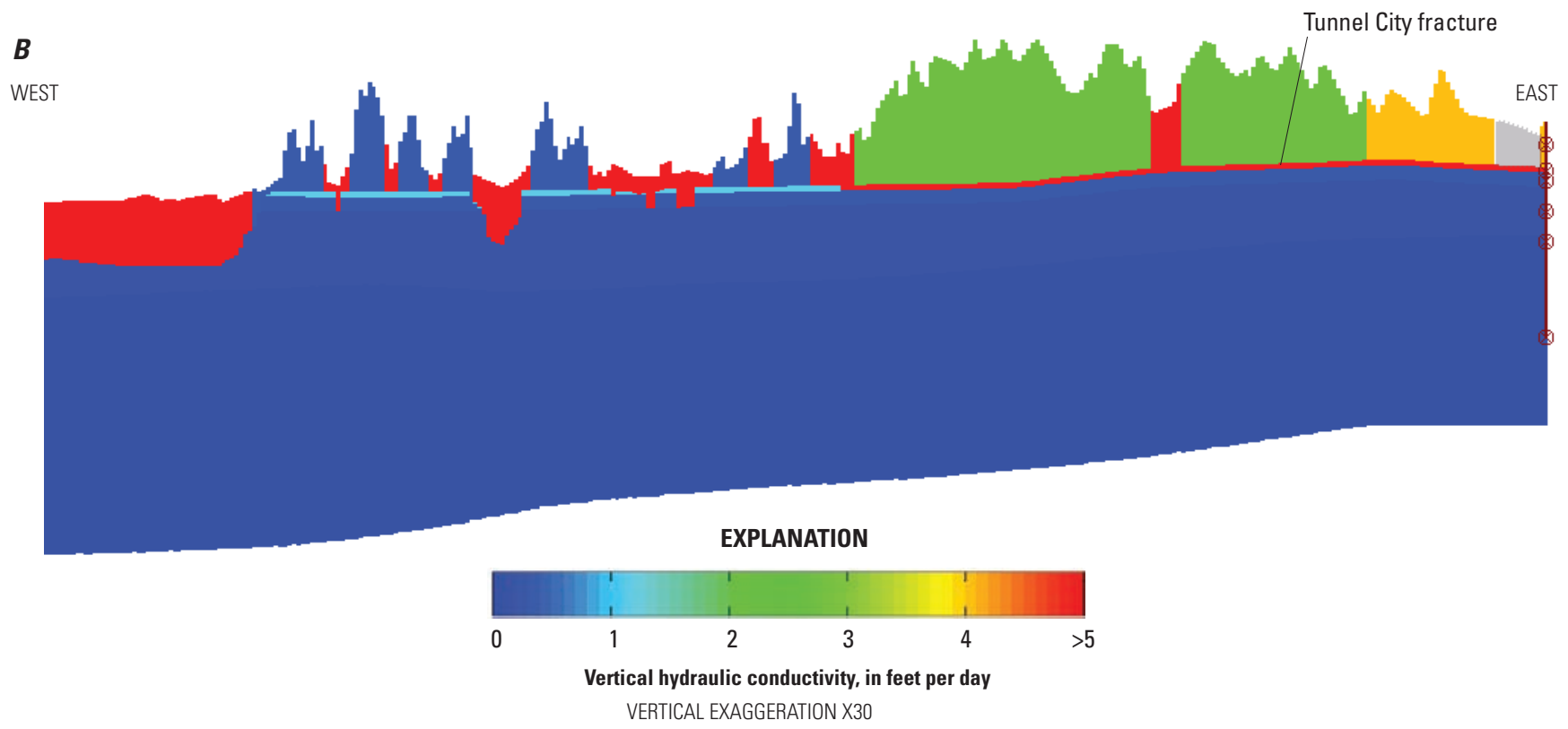

Figure 6-25. Vertical hydraulic conductivity along Row 80 after fully coupled model calibration, shown as a cross section $A$, without vertical exaggeration, and $B$, with a vertical exaggeration of 30 . 


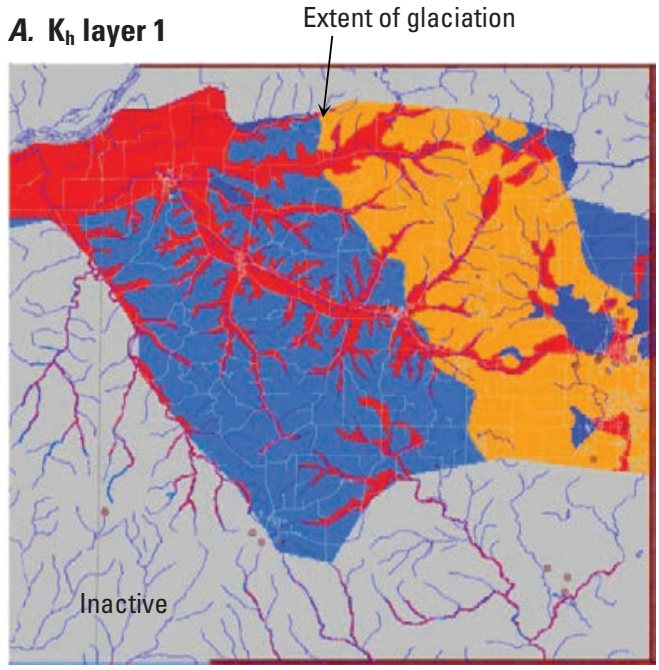

C. $K_{\mathrm{h}}$ layer 3

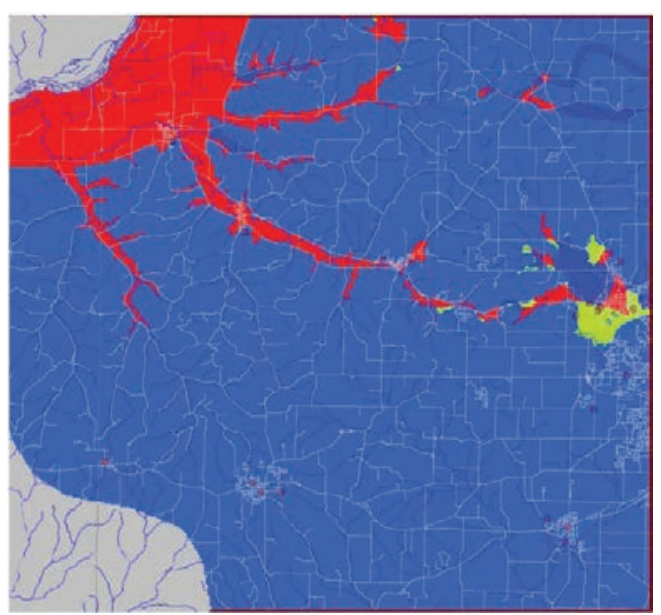

E. $\mathrm{K}_{\mathrm{h}}$ layer $\mathbf{5}$

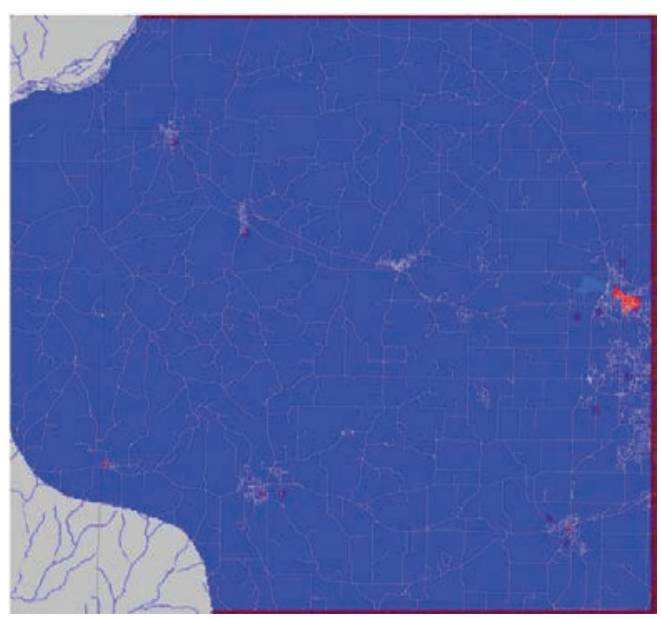

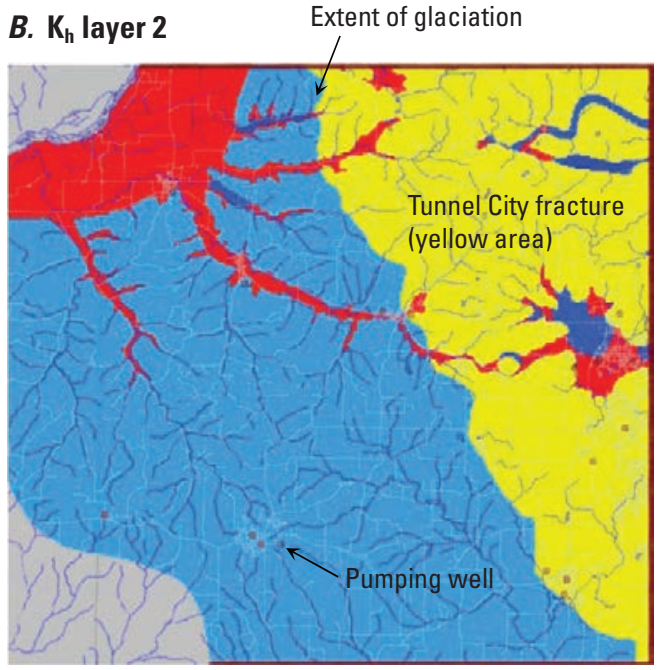

\section{D. $\mathrm{K}_{\mathrm{h}}$ layer 4}

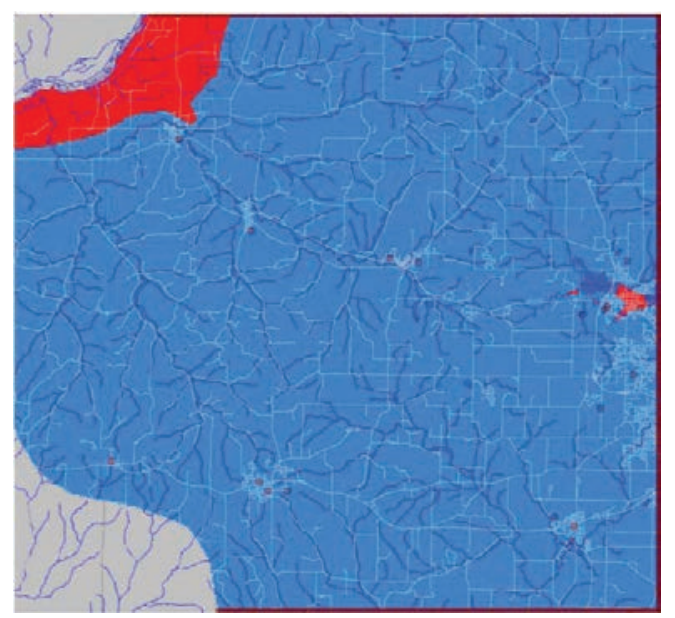

\section{F. $K_{h}$ layer 6}

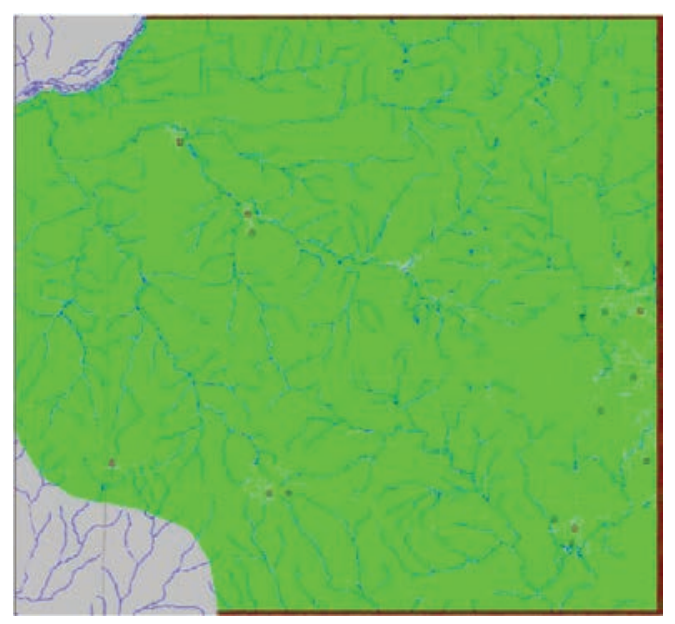

EXPLANATION

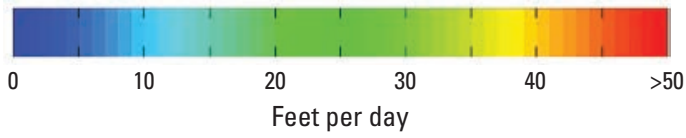

Figure 6-26. Horizontal hydraulic conductivity by layer after fully coupled model calibration. $A, \mathrm{~K}_{\mathrm{h}}$ layer 1. B, $\mathrm{K}_{\mathrm{h}}$ layer 2. $C, \mathrm{~K}_{\mathrm{h}}$ layer $3 . D, \mathrm{~K}_{\mathrm{h}}$ layer $4 . E, \mathrm{~K}_{\mathrm{h}}$ layer $5 . F, \mathrm{~K}_{\mathrm{h}}$ layer 6. 

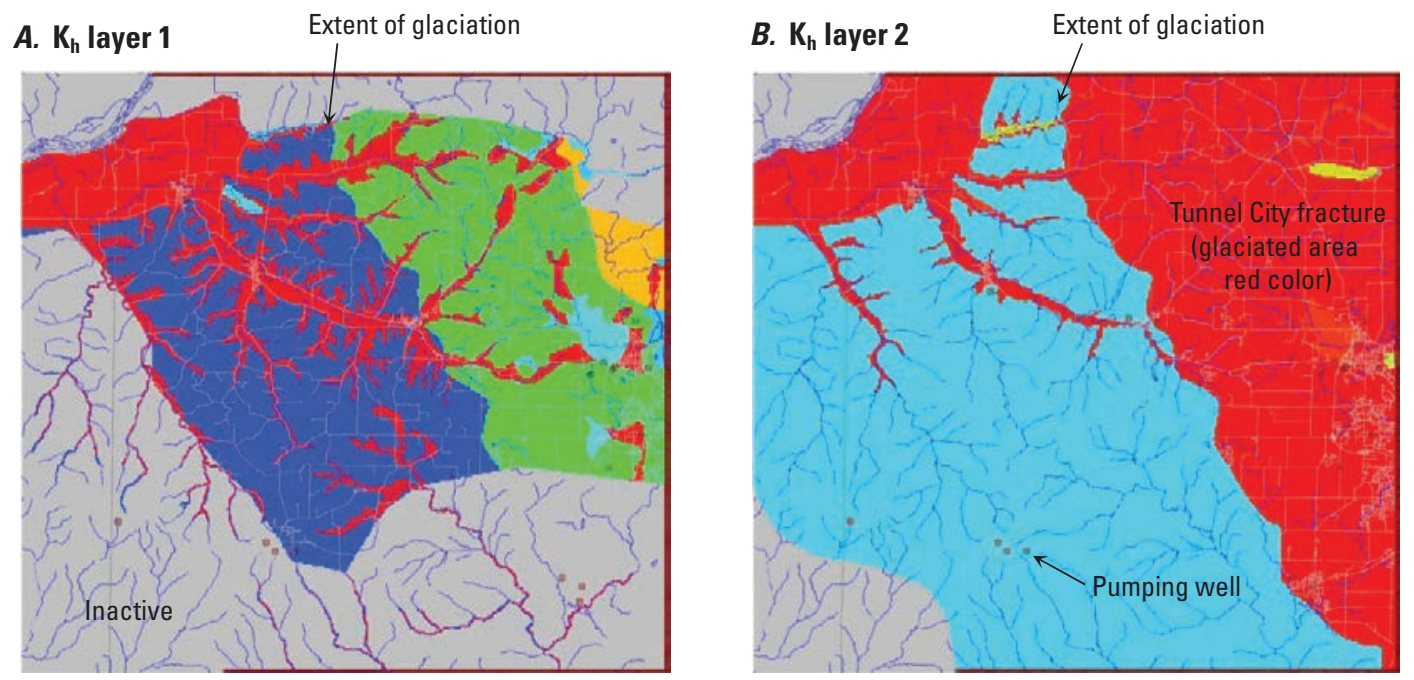

\section{C. $\mathrm{K}_{\mathrm{h}}$ layer 3}

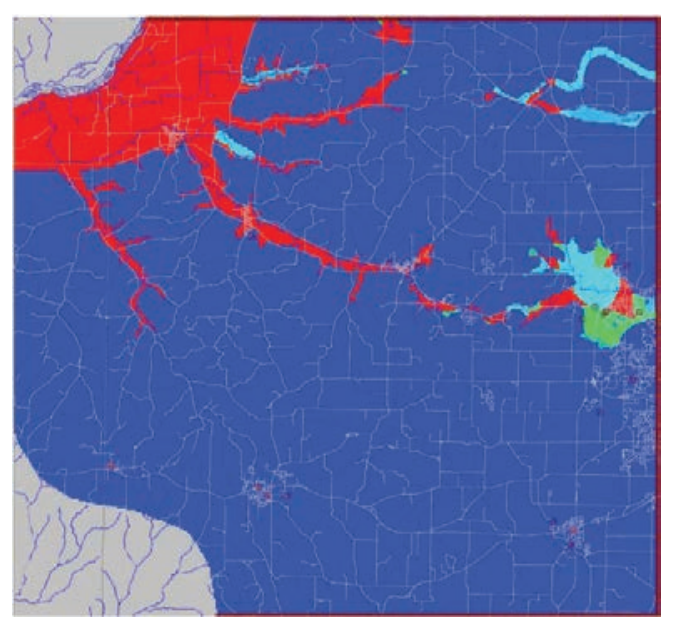

\section{D. $K_{h}$ layer 4}

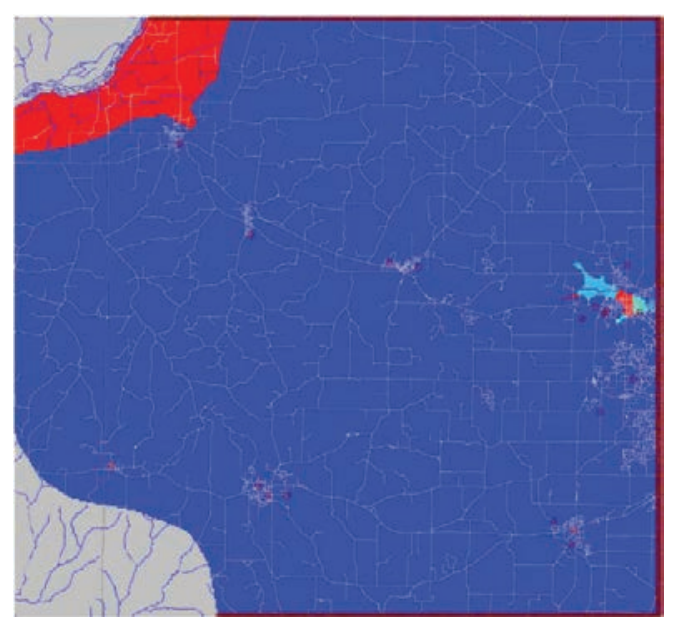

\section{E. $K_{h}$ layer 5}

\section{F. $K_{h}$ layer 6}
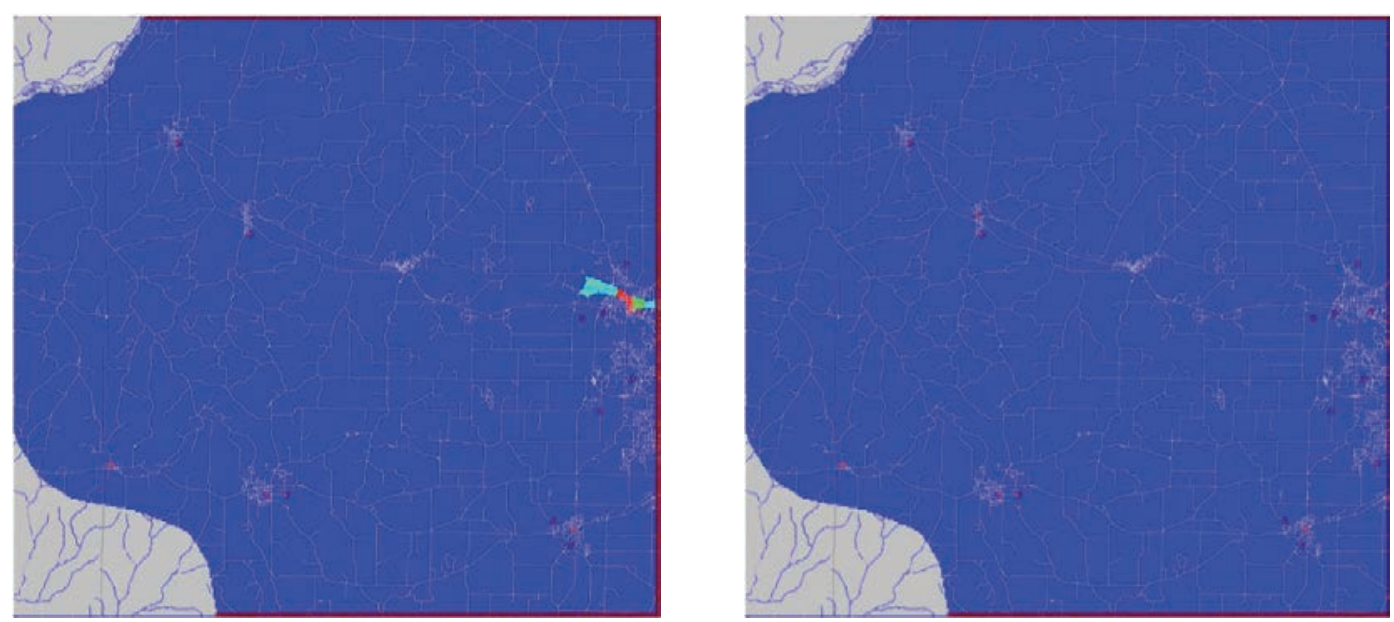

EXPLANATION

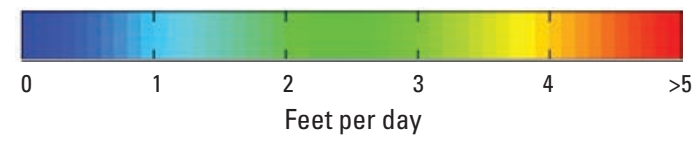

Figure 6-27. Vertical hydraulic conductivity by layer after fully coupled model calibration. $A, \mathrm{~K}_{\mathrm{h}}$ layer 1. B, $\mathrm{K}_{\mathrm{h}}$ layer 2. $C, \mathrm{~K}_{\mathrm{h}}$ layer $3 . D, \mathrm{~K}_{\mathrm{h}}$ layer $4 . E, \mathrm{~K}_{\mathrm{h}}$ layer $5 . F, \mathrm{~K}_{\mathrm{h}}$ layer 6. 


\section{References Cited}

Clayton, L., and Attig, J.W., 1997, Pleistocene geology of Dane County, Wisconsin: Wisconsin Geological and Natural History Survey Bulletin 95, 64 p.

Hunt, R.J., Feinstein, D.T., Pint, C.D., and Anderson, M.P., 2005, The importance of diverse data types to calibrate a watershed model of the Trout Lake Basin, northern Wisconsin, USA: Journal of Hydrology, v. 321, no. 1-4, p. 286-296, doi:10.1016/j.jhydrol.2005.08.005

Hydro-Search, Inc., 1991, Groundwater monitoring study at the Refuse Hideaway Landfill, Middleton, Wisconsin: Brookfield, Wisconsin, Hydro-Search, Prepared for the Wisconsin Department of Natural Resources, 15 p.

Krohelski, J.T., Bradbury, K.R., Hunt, R.J., and Swanson, S.K., 2000, Numerical simulation of ground-water flow in Dane County, Wisconsin: Wisconsin Geological and Natural History Survey Informational Circular, $44 \mathrm{p}$.

McGrath, R.W., 1991, Investigation of atrazine contamination in bedrock aquifers, Western Dane County, Wisconsin: Department of Geology and Geophysics, University of Wisconsin-Madison, M.S. Thesis, 218 p. 
Publishing support provided by:

The Madison and Rolla Publishing Service Centers

For more information concerning this report, contact:

Director, Wisconsin Water Science Center

U.S. Geological Survey

8505 Research Way

Middleton, Wisconsin 53562

(608) 828-9901

Or visit the Wisconsin Water Science Center Web site at: http://wi.water.usgs.gov 



\section{$\frac{\mathbb{2}}{\mathrm{C}}$}

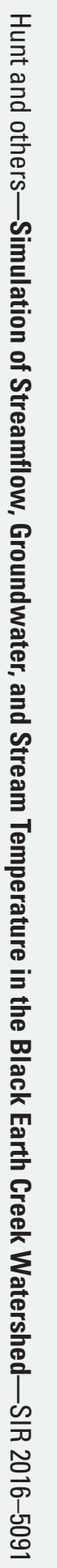

